AgGRADATION AND DEgRADATION OF ALLUVIAL SAND DEPOSITS, 1965 TO 1986, COLORADO RIVER, GRAND CANYON NATIONAL PARK, ARIZONA

By John C. Schmidt and Julia B. Graf

U.S. GEOLOGICAL SURVEY

Open-File Report 87-555

Prepared in cooperation with the

U.S. BUREAU OF RECLAMATION 


\section{DEPARTMENT OF THE INTERIOR \\ DONALD PAUL HODEL, Secretary}

U.S. GEOLOGICAL SURVEY

Dallas L. Peck, Director

Index terms for this report are: Alluvial deposits, dam effects, flow separation, geomorphology, Grand Canyon, Colorado River, Arizona

For additional information write to:

District Chief

U.S. Geological Survey

Box FB-44

Federal Building

$300 \mathrm{~W}$. Congress Street

Tucson, Arizona 85701
Copies of this report can be purchased from:

U.S. Geological Survey

Books and Open-File Reports Section

Box 25425

Federal Center, Bldg. 810

Denver, Colorado 80225 


\section{CONTENTS}

Page

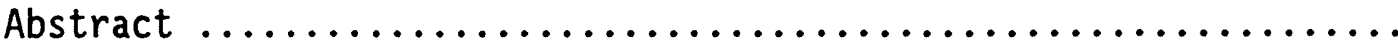

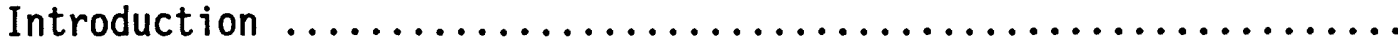

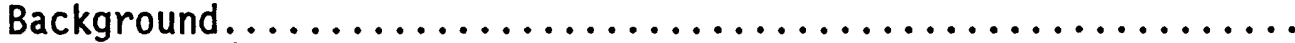

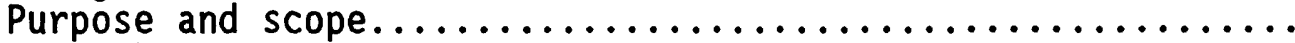

Acknowledgments..................................

Terminology

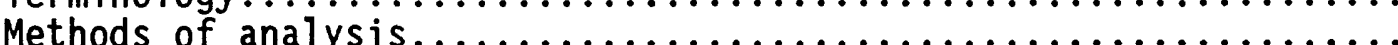

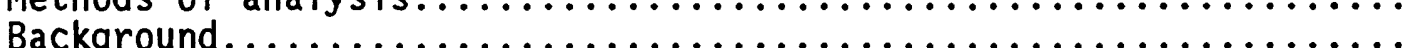

Physicai and hydraulic characteristics of the channei..........

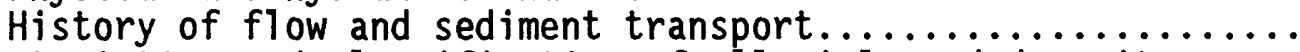

Characteristics and classification of alluvial sand deposits......

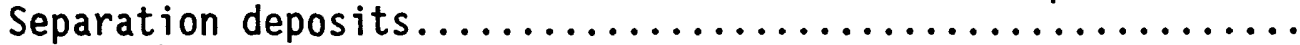

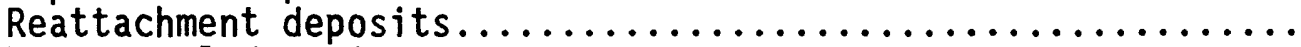

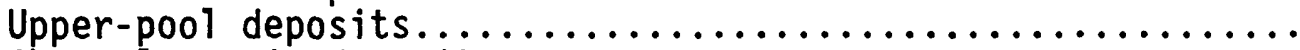

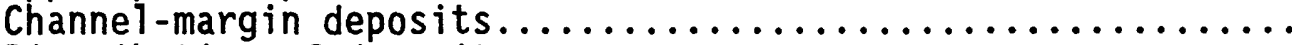

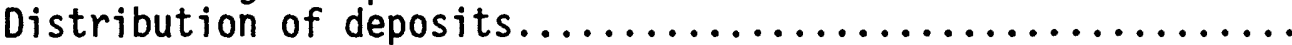

Aggradation and degradation at Eighteen Mile Wash, 1965-86........

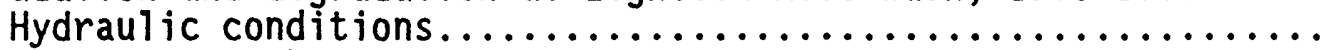

Topographic changes of the separation deposit..............

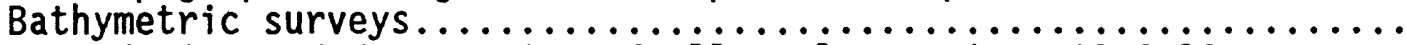

Aggradation and degradation of alluvial deposits, 1965-86........

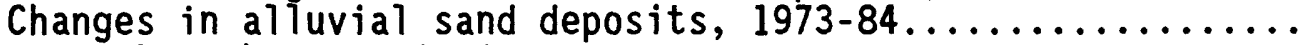

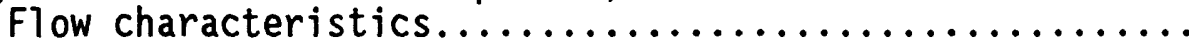

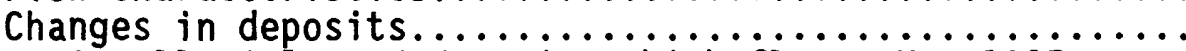

Changes in alluvial sand deposits, high fiows, May $1985 . . .$.

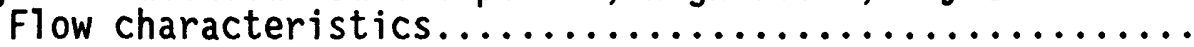

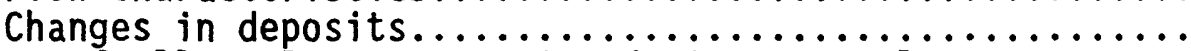

Changes of alluvial sand deposits during strongly

fluctuating flow, October 1985 to January $1986 . . . \ldots \ldots \ldots$.

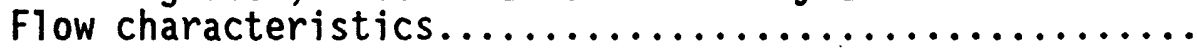

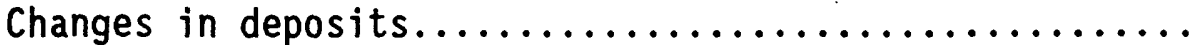

Comparison of changes in alluvial sand deposits.............

Summary...

References cited.

Appendix A.

...... 
Page

Figure 3. Diagrams showing flow patterns and configuration of bed deposits in a typical recirculation zone..

4-5. Maps showing:

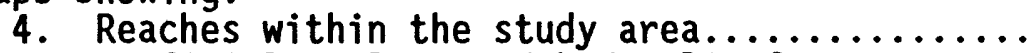

5. Surficial geology and hydraulic features at Badger Creek Rapid..................

6-9. Graphs showing:

6. Change in recirculation-zone length with

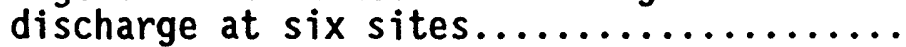

7. Typical particle-size distributions for samples of suspended sediment, bedload, and bed material from the Colorado River near Grand Canyon at river mile 87 and

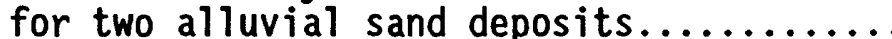

8. Daily mean discharge of the Colorado River at Lees Ferry, $1957 \ldots \ldots \ldots \ldots \ldots \ldots \ldots \ldots$

9. Daily mean discharge of the Colorado River at Lees Ferry, 1982 to February $1986 . . . \ldots$.

10. Photograph showing separation deposits downstream from Badger Creek Rapid, July 30, 1985......... 11-12. Maps showing:

11. Surficial geology and hydraulic features near Eighteen Mile Wash

12. Topography of separation deposit at Eighteen Mile Wash in 1975 and at selected times in 1985 .

13. Cross section showing topography and sedimentology associated with upstream advancement of slipface, May 22, 1985, and August 2, 1985, at Eighteen Mile Wash........

14. Aerial photograph and map showing surficial geology and hydraulic features at Eminence

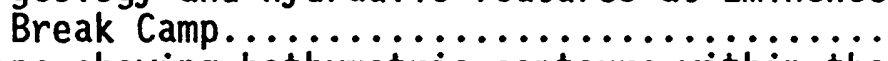

15. Maps showing bathymetric contours within the

16. Graphs showing bed-surface profiles of recirculation zone, Eminence Break Camp.........

17. Aerial photograph and map showing surficial geology, hydraulic features, area of sand inundated at different discharges, and sediment-sampling sites at Saddle Canyon.........

18. Photograph showing reattachment deposit at Eminence Break Camp, October 12, 1985, discharge 3,000 cubic feet per second.................

19-22. Sketches showing:

19. Reattachment deposit at low discharge......

20. Response of a reattachment deposit

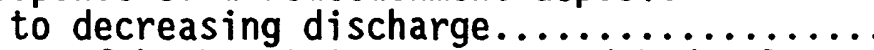

21. Area of bathymetric surveys and hydraui ic

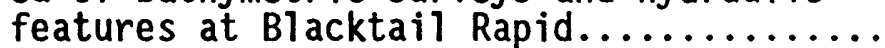

22. Bathymetric contours within a recirculation

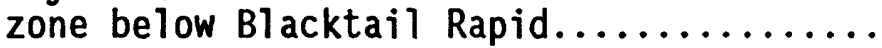


Figure 23. Graphs showing bed-surface profiles of recirculation zone below Blacktail Rapid.........

24. Sketch showing sedimentology exposed in a trench through the reattachment deposit at the site

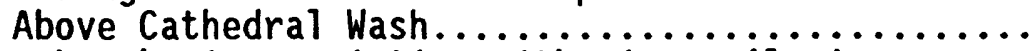

25. Graphs showing variation with river mile in number of alluvial deposits identified

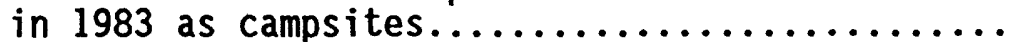

26. Aerial photographs showing Colorado River near

Eighteen Mile Wash...........................

27. Sketch showing topography along profile 2 at

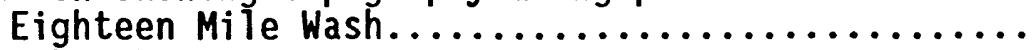

28-29. Graphs showing:

28. Discharge and stage during recession of high flows at Eighteen Mile Wash..........

29. Net-elevation change of separation deposit at Eighteen Mile Wash, 1965 to January 1986, along profile 2 ..

30. Aerial photograph and map showing area of bathymetric survey, surficial geology, and hydrautic features at National Rapid............

31. Maps showing bathymetric contours with in a recirculation zone below National Rapid.........

32-33. Graphs showing:

32. Bed-surface profiles of a recirculation zone below National Rapid...............

33. Vertical change along profile iines at 13 separation deposits between October 1985 and January $1986 . . . \ldots \ldots \ldots$.

34. Graphs and map showing surficial geology and topography along two profiles at Twenty-Nine Mile Rapid... Vine

\section{TABLES}

Table 1. Summary of study sites and types of data collected.....

2. Characteristics of the reaches within the study area...

3. Channel geometry and hydraulic characteristics

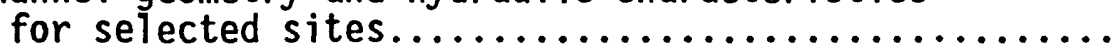

4. Detailed study sites in relation to reaches...............

5. Particle-size characteristics of alluvial sand deposits between Lees Ferry at river mile 0 and Bright Angel Creek at river mile 87.5..............

6. Summary statistics of particle-size characteristics....

7. Areas of alluvial sand deposits at low discharge in

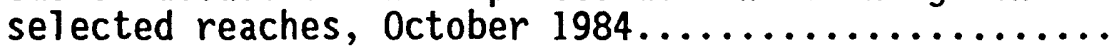

8. Summary of changes between bathymetric surveys........... 
Table 9. Number of separation and reattachment deposits in recirculation zones between river miles 0 and 118 ,

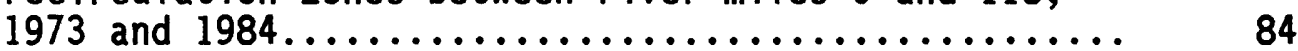

10. Areas of major alluvial sand deposits in selected

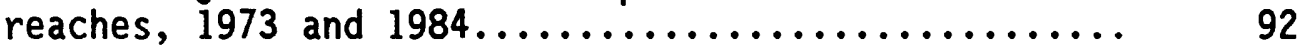

11. Number of deposits that underwent change, 1973-84..... 94

12. Classification of deposits studied by Howard (1975) and Beus and others (1985)...................... 94

13. Summary of measured changes at 20 sites during fluctuating flow, October 1985 to mid-January 1986... 96

14. Areas of exposed sand at detailed study sites, 1965,1973 , and 1984 .

\section{CONVERSION FACTORS}

For readers who prefer metric (International System) units, the conversion factors for inch-pound units used in this report are listed below:

Multiply inch-pound unit

foot $(\mathrm{ft})$

mile (mi)

square foot $\left(\mathrm{ft}^{2}\right)$

cubic foot per second $\left(\mathrm{ft}^{3} / \mathrm{s}\right)$

ton (short)
By

0.3048

1.609

0.0929

0.02832

0.9072
To obtain metric unit meter $(\mathrm{m})$ kilometer $(\mathrm{km})$ square meter $\left(\mathrm{m}^{2}\right)$ cubic meter per second $\left(\mathrm{m}^{3} / \mathrm{s}\right)$

megagram (Mg)

Sea level: In this report "sea level" refers to the National Geodetic Vertical Datum of 1929 (NGVD of 1929)--a geodetic datum derived from a general adjustment of the first-order level nets of both the United States and Canada, formerly called "Mean Sea Level of 1929." 


\title{
AGGRADATION AND DEGRADATION OF ALLUVIAL SAND DEPOSITS, 1965 TO 1986, COLORADO RIVER, GRAND CANYON NATIONAL PARK, ARIZONA
}

By

John C. Schmidt and Julia B. Graf

\begin{abstract}
Alluvial sand deposits along the Colorado River in Grand Canyon National Park are used as campsites and are substrate for vegetation. The largest and most numerous of these deposits are formed in zones of recirculating current that are created downstream from where the channel is constricted by debris fans at tributary mouths. Alluvial sand deposits are classified by location and form. Separation and reattachment deposits are located downstream from constrictions with in recirculation zones. Separation deposits are located near the point of flow separation and typically mantle large debris fans. Reattachment deposits are located near the point of flow reattachment and project upstream beneath much of the zone of recirculating current. Upper-p001 deposits are located upstream from a constriction and are associated with backwaters. Channel-margin deposits line the channel and have the form of terraces. Some are created in small recirculation zones.

Reattachment and channel-margin deposits are largest and most numerous in wide reaches although small channel-margin deposits are used as campsites in the narrow Muav Gorge. Separation deposits are more uniformly distributed throughout Grand Canyon National Park than are other types of deposits. In some narrow reaches where the number of alluvial sand deposits used as campsites is small, separation deposits are a high percentage of the total.
\end{abstract}

During high flows, both separation and reattachment deposits are initially scoured but subsequently redeposited during flow recession. Sand is also exchanged between the main channel and recirculation zones. The rate of recession of high flows can affect the elevation of alluvial deposits that are left exposed after a flood has passed. Fluctuating flows that follow a period of steady discharge cause initial erosion of separation and reattachment deposits. A part of this eroded sand is transported to the main channel. Therefore, sand is exchanged between the main channel and recirculation zones and redistributed within recirculation zones over a broad range of discharges.

Comparison of aerial photographs and reinterpretation of published data concerning changes of alluvial sand deposits following recession of high flows in 1983 and 1984 indicate that sand was eroded from recirculation zones in narrow reaches. In wide reaches, however aggradation in recirculation zones may have occurred. In narrow reaches, 
decrease of reattachment deposits was greater than that of separation deposits. In all reaches, the percentage of separation deposits that maintained a constant area was greater than for other deposits. Separation deposits, therefore, appear to be the most stable of the deposit types.

Fluctuating flows between October 1985 and January 1986, which followed the higher and steadier flows of 1983 to 1985 , caused erosion throughout the park. For separation deposits, erosion was greatest at those sites where deposition from the 1983 high flows had been greatest. The existing pattern of low campsite availability in narrow reaches and high campsite availability in wide reaches was thus accentuated by the sequence of flows between 1983 and 1985 .

\section{INTRODUCTION}

\section{Background}

Alluvial sand deposits are used as campsites by backpackers and by about 15,000 persons who float the Colorado River in boats or rafts through Grand Canyon National Park each year. Sand deposits also are substrate for riparian vegetation. Flow in the Colorado River through Grand Canyon National Park has been regulated by Glen Canyon Dam since its completion in 1963 (fig. 1). From 1963 to 1982 regulation has greatly decreased the range of discharges that occurred in any given year but greatly increased the range that occurred in a given day.

The mean annual peak discharge of the Colorado River before flow regulation (1921-62) was $93,400 \mathrm{ft}^{3} / \mathrm{s}$; this decreased to about $29,200 \mathrm{ft}^{3} / \mathrm{s}$ after regulation (1963-82). For most of 1965 through 1982 , flow was regulated in direct response to electrical power demand. During a typical 24-hour period, the discharge range was large because power demand is high during daylight hours and low at night (fig. 2). Although flow through the powerplant at the dam could range from 1,000 to $31,500 \mathrm{ft}^{3} / \mathrm{s}$, discharge rarely varied over this entire range in a given day. A daily discharge range of 10,000 to $20,000 \mathrm{ft}^{3} / \mathrm{s}$ was typical of the period. Unusually 7 arge releases of water using river outlet works which bypass the powerplant and (or) spillways occurred in 1983, 1984, and 1985. In 1983, peak discharge at Lees Ferry $(09380000$ Colorado River at Lees Ferry, fig. 1) was $97,300 \mathrm{ft}^{3} / \mathrm{s}$. In 1984 and 1985, peak discharge at Lees Ferry was 58,200 and $47,900 \mathrm{ft}^{3} / \mathrm{s}$, respectively.

Before construction of Glen Canyon Dam, the Colorado River carried a large suspended-sediment $70 a d$ through Grand Canyon National Park. All the sediment from the drainage area above the dam is now trapped in Lake Powell formed behind Glen Canyon Dam. Suspended-sediment samples collected at the gaging station at Lees Ferry between 1928 and 1959 commonly exceeded 10,000 ppm (parts per million). In contrast, suspended-sediment samples collected since dam construction are typically less than $200 \mathrm{ppm}$.

Concern was first raised in the mid-1970's that the combination of large daily discharge ranges typical of regulated flow and the loss of 


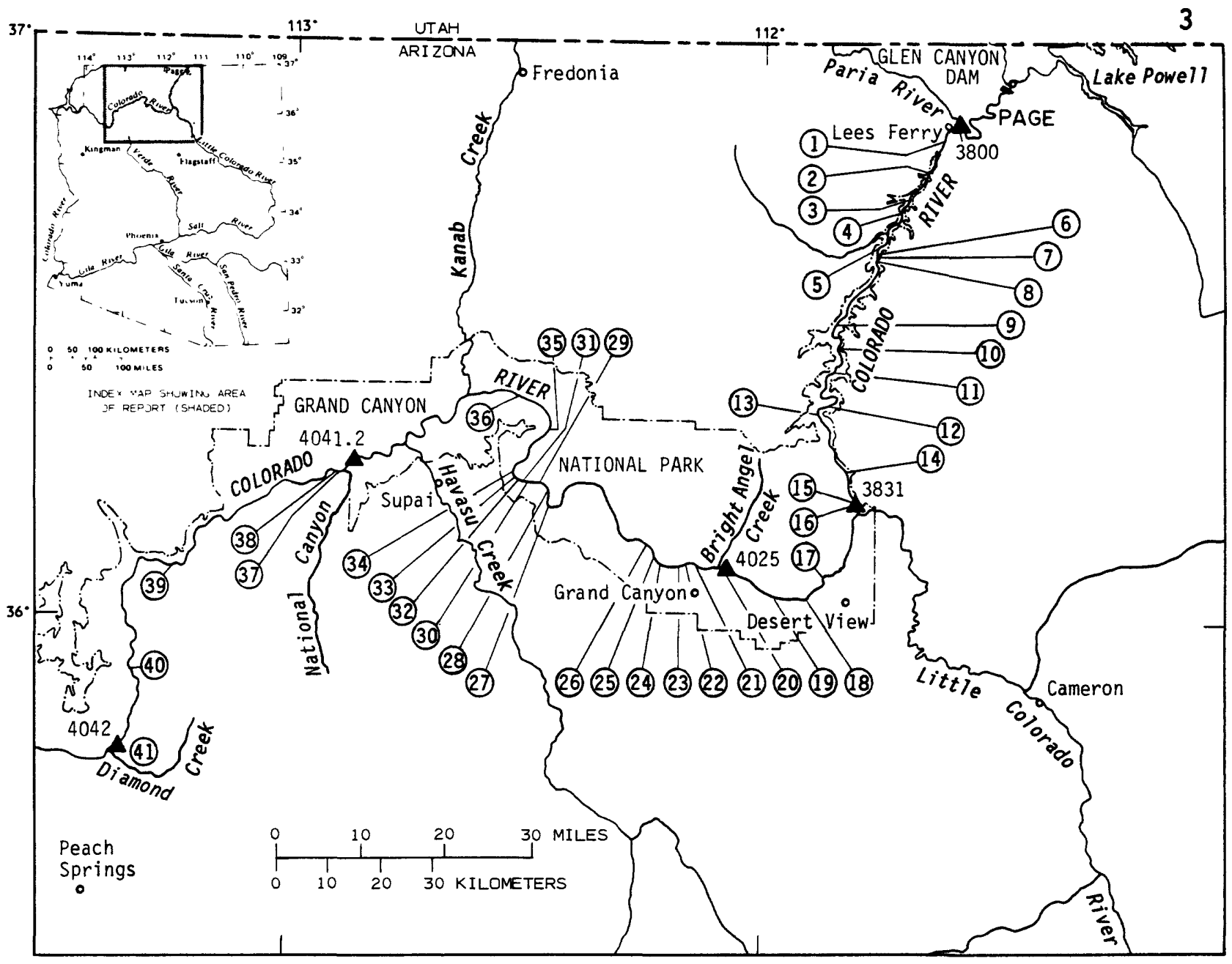

EXPLANATION

$\boldsymbol{\Delta}_{3800}$ gaging Station AND ABBREVIATED NUMBeR

(1) STUdY SITE LISTED IN TABLE 1

Figure 1.--Study area and location of study sites. 


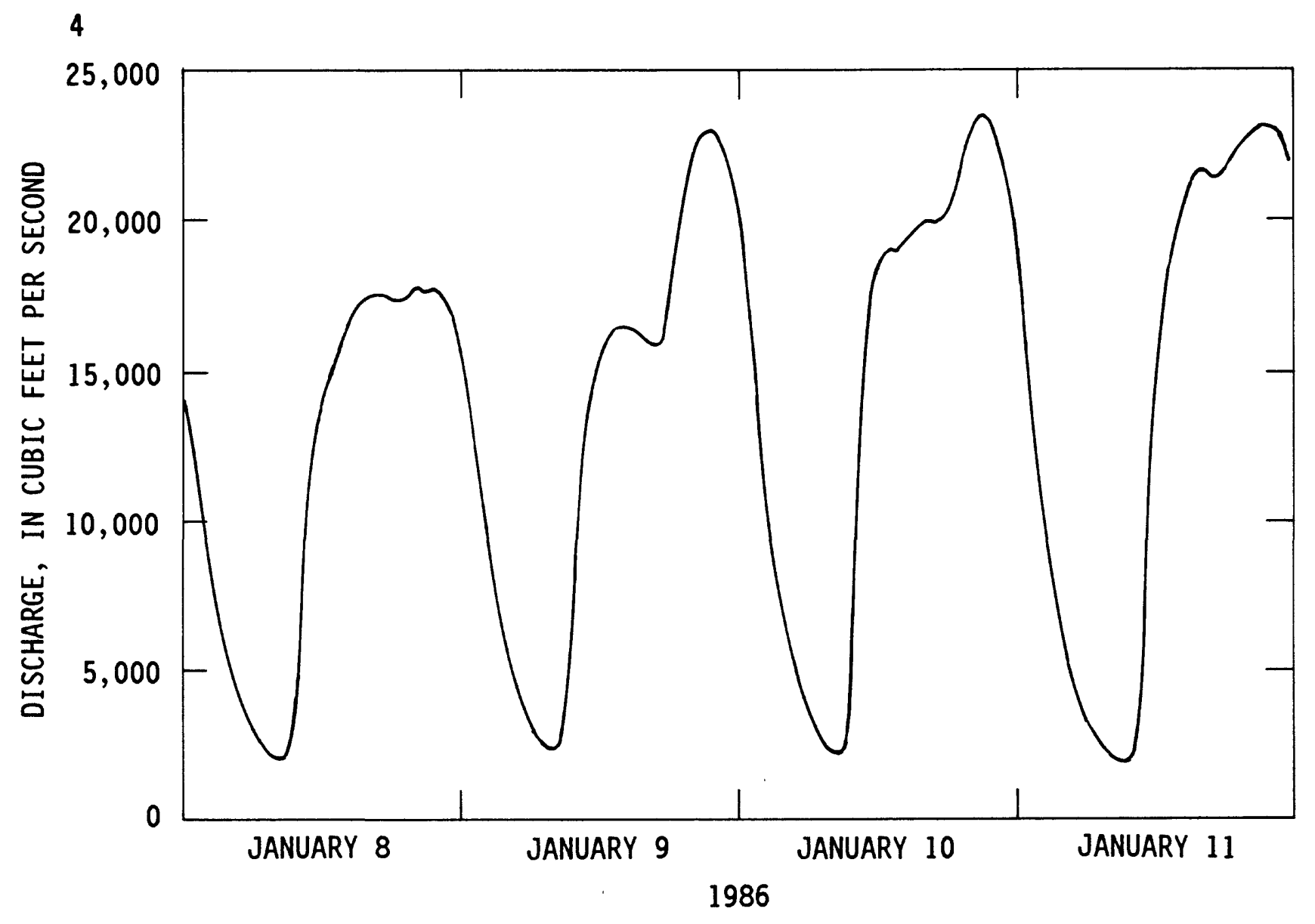

Figure 2.--Instantaneous discharge at Lees Ferry gage, January 8-11, 1986, typical of fluctuating flows between 1965 and 1982 . 
sediment supplied from areas upstream from the dam would cause a decrease in the size and number of alluvial sand deposits within the park. Laursen and others (1976) estimated both the capacity of the regulated river to transport sand and the amount of sediment supplied by tributaries below the dam. They predicted that sand deposits would eventually be depleted because transport capacity exceeded supply under regulated flow. Although Dolan and others (197.4) suggested that widespread degradation of sand deposits might result from operations of the dam, Howard and Dolan (1981) found that sand deposits had "suffered only a very slight erosion." Howard and Dolan (1981) estimated that alluvial sand deposits had reached equilibrium by the late 1970's, and they predicted little net change in the future. They stated, however, that erosion might occur if the characteristic pattern of dam releases of the 1970's were changed.

On the basis of an inventory made after the high releases in 1983, Brian and Thomas (1984) concluded that a net loss of sand deposits large enough for use as campsites had taken place in the first $173 \mathrm{mi}$ below Lees Ferry. They also concluded that a net increase in the same type of sand deposits had taken place farther downstream. Beus and others (1985) evaluated the history of change of 20 major sand deposits between 1974 and 1984 by repeating topographic surveys first begun by Howard (1975). Beus and others (1985) concluded "a substantial net gain of sand [due to high flows in 1983]* * *more than compensated for the previous 8-year loss."

\section{Purpose and Scope}

The present study of alluvial sand deposits along the Colorado River began in 1984 in cooperation with the U.S. Bureau of Reclamation as one phase of a comprehensive investigation of the effects of flow regulation on sediment transport in Grand Canyon National Park. The investigation was initiated in response to a U.S. Bureau of Reclamation proposal to increase peak powerplant discharges from 31,500 to $33,100 \mathrm{ft}^{3} / \mathrm{s}$. High discharges between $1983-85$ al so provided an opportunity to investigate the effects of discharges that exceed powerplant capacity. Other phases of the overall study include:

1. Collection and analysis of flow and sedimenttransport data at gaging stations (Graf, 1986; Pemberton and Randle, 1986);

2. Analysis of historical data from gaging stations (Burkham, 1986);

3. Mapping of channel-bed materials (Wilson, 1986);

4. Development and application of a sediment-transport model in the main channel (Orvis and Randle, 1986 Pemberton and Randle, 1987); and

5. Evaluation of sediment contributions from ungaged tributaries by debris flows (Webb, 1987).

The results of this study will be integrated with results of other phases to determine the effect of flow regulation on sediment transport and storage in the Colorado River in Grand Canyon National Park. 
The study involved the evaluation of existing data and the collection of new data. Existing data consist mainly of aerial and ground photography (Laursen and Silverston, 1976; National Park Service, unpublished 1975 photographs on file at Grand Canyon National Park; Turner and Karpiscak, 1980) and topographic surveys of deposits begun in 1974 (Howard, 1975; Beus and others, 1985; Ferrari, 1987). Data for this study were collected from May 1984 to February 1986. These data included measurements of flow velocity, scour-and-fill of sand deposits, topographic and bathymetric surveys, mapping surface-flow patterns, water-surface slope surveys, sedimentological analysis of some sand deposits, and replication of photographs.

The study area extends from the gaging station (Colorado River at Lees Ferry) at river mile 0 to the gaging station (station 09404200, Colorado River above Diamond Creek, at Peach Springs) at river mile 225 (fig. 1). Most of the fieldwork was done on raft trips beginning at Lees Ferry and ending at either Diamond Creek (river mile 225) or on Lake Mead (river mile 280). A helicopter was used to reach some sites on December 7 and 8, 1985, and on January 8 and 13, 1986.

Forty-one study sites were selected as a representative sample of different types of alluvial sand deposits used as campsites in most major reaches of the Colorado River corridor. The 41 sites and the types of data collected at them are summarized in table 1. The results of topographic and bathymetric surveys at 21 of these sites are discussed in this report. The 21 sites are referred to as detailed study sites.

Bathymetric surveys were limited to reaches where a raft could be safely maneuvered and instruments could receive signals. In spite of the 1 imitations, bathymetric surveys permitted mapping of large areas not otherwise accessible. Topographic surveying was limited to areas of safe wading; however, at low stages, large areas at some study sites could be mapped. Mapping was done of surface-current patterns and shorelines at two or more discharges. Surface velocities were estimated by timing floating objects and by using current meters. Bathymetric surveys were made at discharges between about 15,000 and $25,000 \mathrm{ft}^{3} / \mathrm{s}$ (table 1). 0ther observations and surveys were made at discharges between about 3,000 and $45,000 \mathrm{ft}^{3} / \mathrm{s}$.

The purposes of this report are (1) to present a classification of alluvial sand deposits in the Colorado River, (2) to describe significant characteristics of these deposits, (3) to describe changes in these deposits between June 1983 and January 1986, and (4) to relate these changes to those occurring since completion of the dam. The classification of alluvial sand deposits and identification of 11 reaches within Grand Canyon National Park are presented to provide a framework within which to evaluate changes in deposits. Description of the characteristics of alluvial sand deposits is included to substantiate the classification and to provide a basis for understanding change in spatial distribution of sand. Changes in alluvial deposits were identified by (1) topographic and bathymetric surveys between April 1985 and January 1986 and (2) analysis of aerial photographs. 
[Letter, $X$, indicates data were collected. Dashes indicate no data collected. (DSS), detailed study site]

\begin{tabular}{|c|c|c|c|c|c|c|c|c|c|c|}
\hline $\begin{array}{l}\text { River } \\
\text { mile }\end{array}$ & $\begin{array}{l}\text { Site } \\
\text { num- } \\
\text { ber }\end{array}$ & $\begin{array}{l}\text { Date and } \\
\text { time of } \\
\text { study } 1\end{array}$ & $\begin{array}{l}\text { Discharge, } \\
\text { in cubic } \\
\text { feet per } \\
\text { second }{ }^{2}\end{array}$ & $\begin{array}{l}\text { Bathy- } \\
\text { metric } \\
\text { survey }\end{array}$ & $\begin{array}{l}\text { Topo- } \\
\text { graphic } \\
\text { survey }\end{array}$ & $\begin{array}{l}\text { Photo- } \\
\text { graphic } \\
\text { repli- } \\
\text { cations }\end{array}$ & $\begin{array}{l}\text { Surface- } \\
\text { flow } \\
\text { pattern }\end{array}$ & $\begin{array}{l}\text { Water- } \\
\text { surface } \\
\text { slope }\end{array}$ & $\begin{array}{l}\text { Scour } \\
\text { chains }\end{array}$ & $\begin{array}{l}\text { Sedi- } \\
\text { men- } \\
\text { tology }\end{array}$ \\
\hline
\end{tabular}

(DSS) Above Cathedral Wash (original surveys)

\begin{tabular}{|c|c|c|c|c|c|c|c|c|c|c|}
\hline \multirow[t]{7}{*}{2.5} & 1 & $05-18-85$ & 44,700 & -- & -- & $\mathbf{x}$ & $\mathrm{x}$ & -- & --- & -- \\
\hline & & $07-29-85$ & $\begin{array}{c}26,000 \\
\text { to } \\
29,000\end{array}$ & --- & --- & $x$ & $x$ & -- & --- & -- \\
\hline & & $\begin{array}{c}08-29-85 \\
(1530)\end{array}$ & 27,100 & $x$ & -- & $x$ & -- & -- & -- & $x$ \\
\hline & & $10-04-85$ & $\begin{array}{c}4,000 \\
\text { to } \\
19,000\end{array}$ & --- & $x$ & $x$ & $x$ & --- & $x$ & -- \\
\hline & & $12-07-85$ & 2,600 & -- & $x$ & -- & -- & -- & --- & -- \\
\hline & & $\begin{array}{c}01-09-86 \\
(1600)\end{array}$ & 16,300 & $x$ & $x$ & $x$ & $x$ & $x$ & $x$ & $\mathbf{x}$ \\
\hline & & $05-13-86$ & 48,500 & --- & --- & -- & $\mathrm{x}$ & -- & --- & -- \\
\hline
\end{tabular}

(DSS) Badger Creek Rapid (original surveys)

\begin{tabular}{|c|c|c|c|c|c|c|c|c|c|c|}
\hline \multirow[t]{7}{*}{7.9} & 2 & $\begin{array}{c}04-13-85 \\
(1400)\end{array}$ & 17,900 & $x$ & -- & -- & -- & --- & -- & -- \\
\hline & & $\begin{array}{c}05-19-85 \\
\text { to } \\
05-21-85\end{array}$ & $\begin{array}{c}40,000 \\
\text { to } \\
45,000\end{array}$ & -- & $x$ & $x$ & $x$ & $x$ & -- & -- \\
\hline & & $\begin{array}{c}07-30-85 \\
\text { to } \\
07-31-85\end{array}$ & $\begin{array}{c}25,000 \\
\text { to } \\
31,000\end{array}$ & --- & $x$ & $x$ & $x$ & $x$ & -- & -- \\
\hline & & $\begin{array}{c}08-30-85 \\
(1500)\end{array}$ & 29,800 & $x$ & --- & -- & -- & -- & $\cdots$ & $x$ \\
\hline & & $\begin{array}{c}10-05-85 \\
\text { to } \\
10-06-85\end{array}$ & $\begin{array}{c}3,000 \\
\text { to } \\
17,000\end{array}$ & -- & $x$ & $x$ & $x$ & $x$ & -- & -- \\
\hline & & $12-07-85$ & $\sim 3,000$ & --- & $\mathrm{x}$ & -- & --- & -- & -- & $\cdots$ \\
\hline & & $\begin{array}{c}01-11-86 \\
(1730)\end{array}$ & $\begin{array}{c}2,870 \\
\text { to } \\
21,500\end{array}$ & $\begin{array}{c}X \\
(2)\end{array}$ & $x$ & $x$ & $x$ & $x$ & -- & $x$ \\
\hline
\end{tabular}

(DSS) Soap Creek Rapid (initial survey, Ferrari, 1987)

\begin{tabular}{|c|c|c|c|c|c|c|c|c|c|c|}
\hline \multirow[t]{4}{*}{11.4} & 3 & $\begin{array}{c}05-21-85 \\
\text { to } \\
05-22-85\end{array}$ & $\begin{array}{c}44,000 \\
\text { to } \\
45,000\end{array}$ & -- & -- & $x$ & $x$ & $x$ & -- & $-\cdots$ \\
\hline & & $08-01-85$ & $\begin{array}{c}25,000 \\
\text { to } \\
31,000\end{array}$ & -- & $x$ & $x$ & $x$ & $x$ & -- & $x$ \\
\hline & & $10-07-85$ & $\begin{array}{r}4,000 \\
18,000\end{array}$ & -- & $x$ & $x$ & $x$ & $x$ & $x$ & -- \\
\hline & & $01-12-86$ & $\begin{array}{c}2,000 \\
\text { to } \\
21,000\end{array}$ & --- & $x$ & $x$ & $x$ & -- & $x$ & $\cdots$ \\
\hline
\end{tabular}

See footnotes at end of table. 
Table 1.--Summary of study sites and types of data collected--Continued

\begin{tabular}{|c|c|c|c|c|c|c|c|c|c|c|}
\hline $\begin{array}{l}\text { River } \\
\text { mile }\end{array}$ & $\begin{array}{l}\text { Site } \\
\text { num- } \\
\text { ber }\end{array}$ & $\begin{array}{l}\text { Date and } \\
\text { time of } \\
\text { study } 1\end{array}$ & $\begin{array}{c}\text { Discharge, } \\
\text { in cubic } \\
\text { feet per } \\
\text { second } 2\end{array}$ & $\begin{array}{l}\text { Bathy- } \\
\text { metric } \\
\text { survey }\end{array}$ & $\begin{array}{l}\text { Topo- } \\
\text { graphic } \\
\text { survey }\end{array}$ & $\begin{array}{l}\text { Photo- } \\
\text { graphic } \\
\text { repli- } \\
\text { cations }\end{array}$ & $\begin{array}{l}\text { Surface- } \\
\text { flow } \\
\text { pattern }\end{array}$ & $\begin{array}{l}\text { Water- } \\
\text { surface } \\
\text { slope }\end{array}$ & $\begin{array}{r}\text { Scour } \\
\text { chains }\end{array}$ & $\begin{array}{l}\text { Sedi- } \\
\text { men- } \\
\text { tology }\end{array}$ \\
\hline
\end{tabular}

(DSS) Below Salt Water Wash (original survey)

\begin{tabular}{|c|c|c|c|c|c|c|c|c|c|c|}
\hline \multirow[t]{4}{*}{12.2} & 4 & $05-21-85$ & $\begin{array}{c}44,000 \\
\text { to }\end{array}$ & --- & --- & --- & $x$ & -- & --- & -- \\
\hline & & $\begin{array}{l}05-22-85 \\
08-01-85\end{array}$ & $\begin{array}{c}45,000 \\
25,000 \\
\text { to } \\
31,000\end{array}$ & --- & --- & $x$ & $x$ & --- & --- & $x$ \\
\hline & & $10-08-85$ & $\begin{array}{c}4,000 \\
\text { to } \\
15,000\end{array}$ & --- & $x$ & $x$ & $x$ & --- & $x$ & $\mathrm{x}$ \\
\hline & & $01-13-86$ & $\begin{array}{c}2,000 \\
\text { to } \\
21,000\end{array}$ & --- & $x$ & $\mathrm{x}$ & $x$ & --- & $x$ & -- \\
\hline
\end{tabular}

(DSS) Eighteen Mile Wash (initial survey Boward, 1975)

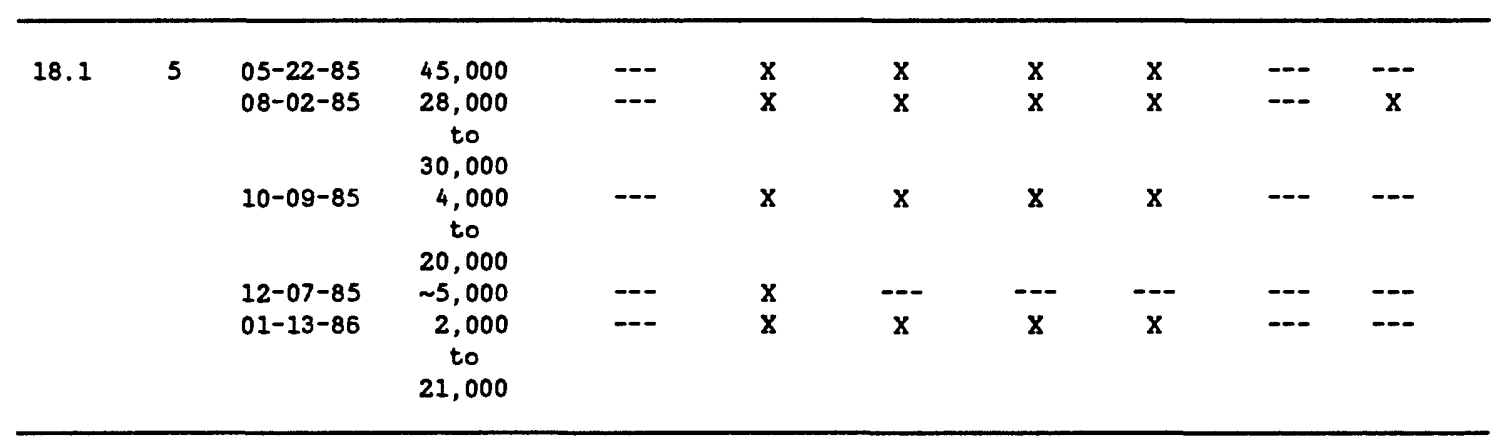

Below Eighteen Mile Wash

\begin{tabular}{|c|c|c|c|c|c|c|c|c|c|c|}
\hline \multirow[t]{2}{*}{18.2} & 6 & $08-02-85$ & $\begin{array}{c}28,000 \\
\text { to } \\
30,000\end{array}$ & --- & -- & $x$ & $x$ & --- & -- & -- \\
\hline & & $10-09-85$ & $\begin{array}{c}4,000 \\
\text { to } \\
20,000\end{array}$ & --- & --- & $x$ & $\mathbf{x}$ & -- & --- & -- \\
\hline
\end{tabular}

(DSS) Opposite Nineteen Mile Canyon (initial survey Howard, 1975)

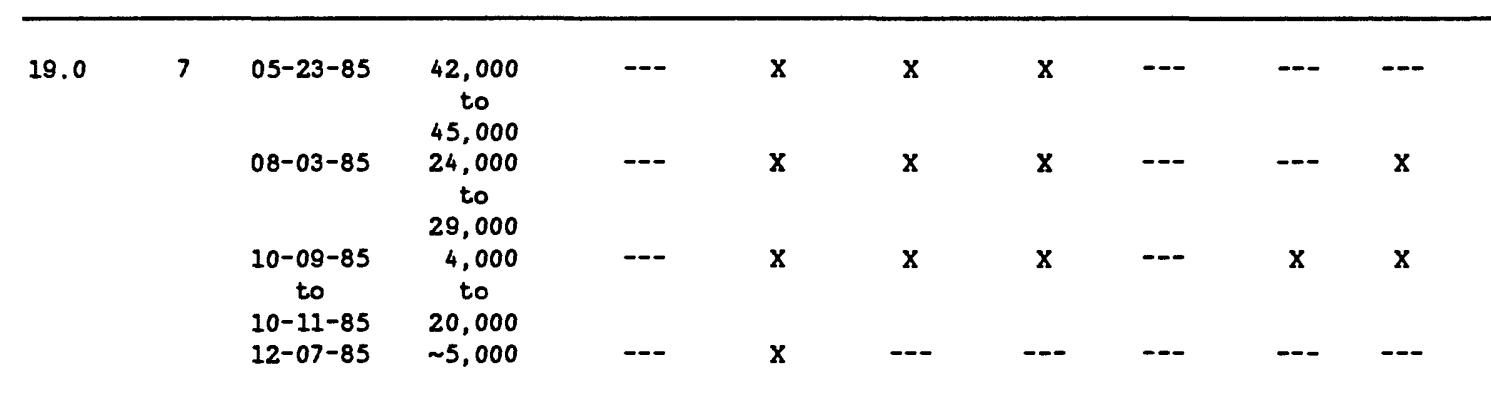

See footnotes at end of table. 
Table 1.--Summary of study sites and types of data collected--Continued

\begin{tabular}{|c|c|c|c|c|c|c|c|c|c|c|}
\hline $\begin{array}{l}\text { River } \\
\text { mile }\end{array}$ & $\begin{array}{l}\text { Site } \\
\text { num- } \\
\text { ber }\end{array}$ & $\begin{array}{l}\text { Date and } \\
\text { time of } \\
\text { studyl }\end{array}$ & $\begin{array}{l}\text { Discharge, } \\
\text { in cubic } \\
\text { feet per } \\
\text { second } 2\end{array}$ & $\begin{array}{l}\text { Bathy- } \\
\text { metric } \\
\text { survey }\end{array}$ & $\begin{array}{l}\text { Topo- } \\
\text { graphic } \\
\text { survey }\end{array}$ & $\begin{array}{l}\text { Photo- } \\
\text { graphic } \\
\text { repli- } \\
\text { cations }\end{array}$ & $\begin{array}{l}\text { Surface- } \\
\text { flow } \\
\text { pattern }\end{array}$ & $\begin{array}{l}\text { Water- } \\
\text { surface } \\
\text { slope }\end{array}$ & $\begin{array}{r}\text { Scour } \\
\text { chains }\end{array}$ & $\begin{array}{l}\text { Sedi- } \\
\text { men- } \\
\text { tology }\end{array}$ \\
\hline
\end{tabular}

(DSS) Opposite Nineteen Mile Canyon (initial survey Howard, 1975)--Continued

\begin{tabular}{|c|c|c|c|c|c|c|c|c|}
\hline $01-14-86$ & $\begin{array}{c}2,000 \\
\text { to } \\
21,000\end{array}$ & -- & $\mathbf{x}$ & $\mathbf{x}$ & $\mathbf{x}$ & $x$ & $\mathbf{x}$ &.-- \\
\hline
\end{tabular}

(DSS) Iwenty Mile Camp (initial survey Ferrari, 1987)

\begin{tabular}{|c|c|c|c|c|c|c|c|c|c|c|}
\hline \multirow[t]{2}{*}{19.8} & 8 & $08-03-85$ & $\begin{array}{c}24,000 \\
\text { to } \\
29,000\end{array}$ & $\cdots$ & $x$ & -- & $\mathbf{x}$ & $\cdots$ & --- & -- \\
\hline & & $\begin{array}{l}10-11-85 \\
01-14-86\end{array}$ & $\begin{array}{c}4,000 \\
\text { to } \\
15,000 \\
2,000 \\
\text { to } \\
21,000\end{array}$ & -- & $x$ & -- & -- & -- & --- & --- \\
\hline
\end{tabular}

(DSS) Twenty-Nine Mile Rapid (original survey)

\begin{tabular}{|c|c|c|c|c|c|c|c|c|c|c|}
\hline \multirow[t]{4}{*}{29.2} & 9 & $05-24-85$ & 44,000 & --- & --- & $x$ & $x$ & --- & --- & -- \\
\hline & & $08-04-85$ & $\begin{array}{c}23,000 \\
\text { to } \\
29,000\end{array}$ & --- & $x$ & $\mathbf{x}$ & $\mathbf{x}$ & --- & --- & $x$ \\
\hline & & $10-11-85$ & $\begin{array}{c}4,000 \\
\text { to } \\
15,000\end{array}$ & --- & $x$ & $\mathbf{x}$ & $x$ & --- & --- & -- \\
\hline & & $\begin{array}{l}12-07-85 \\
01-15-86\end{array}$ & $\begin{array}{c}\sim 5,000 \\
3,000 \\
\text { to } \\
22,000\end{array}$ & --- & $\begin{array}{l}x \\
x\end{array}$ & $x$ & $\bar{x}$ & $x$ & --- & -- \\
\hline
\end{tabular}

(DSS) Nautiloid Canyon (initial survey Howard, 1975)

\begin{tabular}{|c|c|c|c|c|c|c|c|c|c|c|}
\hline \multirow[t]{5}{*}{34.7} & 10 & $05-24-85$ & $\begin{array}{c}44,000 \\
\text { to } \\
48,000\end{array}$ & $\cdots$ & $x$ & $x$ & $\mathbf{x}$ & $\mathbf{x}$ & --- & -- \\
\hline & & $08-04-85$ & $\begin{array}{c}23,000 \\
\text { to } \\
29,000\end{array}$ & -- & $x$ & $\mathbf{x}$ & $x$ & -- & -- & -- \\
\hline & & $\begin{array}{c}09-01-85 \\
(0945)\end{array}$ & 27,600 & $x$ & -- & -- & -- & --- & -- & -- \\
\hline & & $10-12-85$ & $\begin{array}{c}3,000 \\
\text { to } \\
15,000\end{array}$ & -- & $x$ & $\mathbf{x}$ & $x$ & -- & --- & $\therefore-$ \\
\hline & & $\begin{array}{c}01-14-86 \\
\text { to } \\
01-15-86\end{array}$ & $\begin{array}{r}2,360 \\
15,900\end{array}$ & $\begin{array}{c}X \\
(2)\end{array}$ & $x$ & $x$ & $x$ & $x$ & -- & -- \\
\hline
\end{tabular}

See footnotes at end of table. 
Table 1.--Summary of study sites and types of data collected--Continued

\begin{tabular}{|c|c|c|c|c|c|c|c|c|c|c|}
\hline $\begin{array}{l}\text { River } \\
\text { mile }\end{array}$ & $\begin{array}{l}\text { Site } \\
\text { num- } \\
\text { ber }\end{array}$ & $\begin{array}{l}\text { Date and } \\
\text { time of } \\
\text { study } 1\end{array}$ & $\begin{array}{l}\text { Discharge, } \\
\text { in cubic } \\
\text { feet per } \\
\text { second }{ }^{2}\end{array}$ & $\begin{array}{l}\text { Bathy- } \\
\text { metric } \\
\text { survey } 3\end{array}$ & $\begin{array}{l}\text { Topo- } \\
\text { graphic } \\
\text { survey }\end{array}$ & $\begin{array}{l}\text { Photo- } \\
\text { graphic } \\
\text { repli- } \\
\text { cations }\end{array}$ & $\begin{array}{l}\text { Surface- } \\
\text { flow } \\
\text { pattern }\end{array}$ & $\begin{array}{l}\text { Water- } \\
\text { surface } \\
\text { slope }\end{array}$ & $\begin{array}{l}\text { Scour } \\
\text { chains }\end{array}$ & $\begin{array}{l}\text { Sedi- } \\
\text { men- } \\
\text { tology }\end{array}$ \\
\hline \multicolumn{11}{|c|}{ Tatahatso } \\
\hline \multirow[t]{2}{*}{37.3} & 11 & $08-04-85$ & $\begin{array}{c}23,000 \\
\text { to } \\
29,000\end{array}$ & --- & $x$ & $\mathbf{x}$ & --- & --- & --- & --- \\
\hline & & $10-12-85$ & $\begin{array}{c}3,000 \\
\text { to } \\
15,000\end{array}$ & --- & $x$ & -- & -- & -- & --- & --- \\
\hline
\end{tabular}

(DSS) Eminence Break Camp (original survey)

\begin{tabular}{|c|c|c|c|c|c|c|c|c|c|c|}
\hline \multirow[t]{7}{*}{44.2} & 12 & $04-16-85$ & 26,100 & $x$ & -- & $\cdots$ & --- & -- & -- & $\cdots$ \\
\hline & & $\begin{array}{c}(0630) \\
04-17-85\end{array}$ & 26,000 & $x$ & $\ldots$ & --- & $\mathbf{x}$ & -- & --- & -- \\
\hline & & $\begin{array}{c}(0645) \\
05-25-85\end{array}$ & $\begin{array}{c}40,000 \\
\text { to } \\
47,000\end{array}$ & -- & $x$ & $x$ & $x$ & $x$ & -- & -- \\
\hline & & $08-05-85$ & $\begin{array}{c}25,000 \\
\text { to } \\
31,000\end{array}$ & $\cdots$ & $x$ & $x$ & $x$ & $x$ & -- & $\cdots$ \\
\hline & & $\begin{array}{c}09-02-85 \\
(0910)\end{array}$ & 27,200 & $x$ & -- & -- & -- & -- & -- & -- \\
\hline & & $10-12-85$ & $\begin{array}{c}3,000 \\
\text { to } \\
15,000\end{array}$ & -- & $x$ & $x$ & $x$ & $x$ & --- & --- \\
\hline & & $\begin{array}{c}01-16-86 \\
(0915)\end{array}$ & 23,600 & $x$ & $x$ & $x$ & $x$ & $x$ & -- & $x$ \\
\hline
\end{tabular}

(DSS) Saddle Canyon (initial survey Ferrari, 1987)

\begin{tabular}{|c|c|c|c|c|c|c|c|c|c|c|}
\hline 47.2 & 13 & $05-14-86$ & $\begin{array}{c}13,000 \\
\text { to } \\
24,000 \\
48,500\end{array}$ & -- & - & -- & $x$ & -- & -- & -- \\
\hline
\end{tabular}

Kwagunt Rapid (initial surveys Ferrari, 1987)

\begin{tabular}{|c|c|c|c|c|c|c|c|c|c|c|}
\hline 56.3 & 14 & $\begin{array}{l}08-06-86 \\
10-13-85\end{array}$ & $\begin{array}{c}26,000 \\
\text { to } \\
30,000 \\
3,000 \\
\text { to } \\
12,000\end{array}$ & $\cdots$ & $x$ & $\ldots$ & --- & --- & --- & -- \\
\hline
\end{tabular}

See footnotes at end of table. 
Table 1.--Sumnary of study sites and types of data collected--Continued

\begin{tabular}{|c|c|c|c|c|c|c|c|c|c|c|}
\hline $\begin{array}{l}\text { River } \\
\text { mile }\end{array}$ & $\begin{array}{l}\text { S1te } \\
\text { num- } \\
\text { ber }\end{array}$ & $\begin{array}{l}\text { Date and } \\
\text { time of } \\
\text { study } 1\end{array}$ & $\begin{array}{l}\text { Discharge, } \\
\text { in cubic } \\
\text { feet per } \\
\text { second } 2\end{array}$ & $\begin{array}{l}\text { Bathy- } \\
\text { metric } \\
\text { survey } 3\end{array}$ & $\begin{array}{l}\text { Topo- } \\
\text { graphic } \\
\text { survey }\end{array}$ & $\begin{array}{l}\text { Photo- } \\
\text { graphic } \\
\text { repli- } \\
\text { cations }\end{array}$ & $\begin{array}{l}\text { Surface- } \\
\text { flow } \\
\text { pattern }\end{array}$ & $\begin{array}{l}\text { Water- } \\
\text { surface } \\
\text { slope }\end{array}$ & $\begin{array}{l}\text { Scour } \\
\text { chains }\end{array}$ & $\begin{array}{l}\text { Sedi- } \\
\text { men- } \\
\text { tology }\end{array}$ \\
\hline
\end{tabular}

Little Colorado River confluence (original survey)

\begin{tabular}{|c|c|c|c|c|c|c|c|c|c|c|}
\hline \multirow[t]{7}{*}{61.1} & 15 & $\begin{array}{c}04-19-85 \\
(1240)\end{array}$ & 24,000 & $x$ & --- & --- & --- & --- & --- & -- \\
\hline & & $05-27-85$ & $\begin{array}{c}40,000 \\
\text { to } \\
47,000\end{array}$ & --- & --- & $x$ & $x$ & $x$ & --- & -- \\
\hline & & $08-06-85$ & $\begin{array}{c}26,000 \\
\text { to } \\
30,000\end{array}$ & --- & $\mathbf{x}$ & $x$ & $x$ & -- & --- & -- \\
\hline & & $\begin{array}{c}09-03-85 \\
(1105)\end{array}$ & 29,200 & $x$ & --- & --- & --- & -- & --- & -- \\
\hline & & $\begin{array}{c}09-04-85 \\
(0840)\end{array}$ & 26,500 & $x$ & --- & --- & --- & -- & --- & -- \\
\hline & & $\begin{array}{c}01-17-86 \\
(1535)\end{array}$ & 19,600 & $\mathrm{x}$ & --- & -- & --- & --- & --- & -- \\
\hline & & $01-18-86$ & $\begin{array}{c}13,000 \\
\text { to } \\
26,000\end{array}$ & -- & $x$ & $x$ & $x$ & --- & --- & -- \\
\hline
\end{tabular}

Below Little Colorado River confluence (initial survey Howard, 1975)

\begin{tabular}{cccccccccccc}
\hline 61.7 & 16 & $01-20-86$ & $\begin{array}{c}12,000 \\
\text { to } \\
21,000\end{array}$ \\
& & & & & & & & \\
0
\end{tabular}

Above Unkar Rapid (initial survey Ferrari, 1987)

\begin{tabular}{|c|c|c|c|c|c|c|c|c|c|c|}
\hline 72.5 & 17 & $\begin{array}{c}01-19-86 \\
(1400) \\
01-20-86\end{array}$ & $\begin{array}{c}\text { (4) } \\
12,000 \\
\text { to } \\
21,000\end{array}$ & $x$ & $x$ & --- & --- & -- & -- & -- \\
\hline
\end{tabular}

Nevills Rapid (original survey)

\begin{tabular}{|c|c|c|c|c|c|c|c|c|c|c|}
\hline 75.6 & 18 & $\begin{array}{l}08-07-85 \\
01-20-86\end{array}$ & $\begin{array}{c}17,000 \\
\text { to } \\
24,000 \\
12,000 \\
\text { to } \\
21,000\end{array}$ & --- & $x$ & $x$ & $x$ & -- & --- & -- \\
\hline
\end{tabular}

See footnotes at end of table. 
Table 1.--Summary of study sites and types of data collected--Continued

\begin{tabular}{|c|c|c|c|c|c|c|c|c|c|c|}
\hline $\begin{array}{l}\text { River } \\
\text { mile }\end{array}$ & $\begin{array}{l}\text { Site } \\
\text { num- } \\
\text { ber }\end{array}$ & $\begin{array}{l}\text { Date and } \\
\text { time of } \\
\text { study } 1\end{array}$ & $\begin{array}{l}\text { Discharge, } \\
\text { in cubic } \\
\text { feet per } \\
\text { second }{ }^{2}\end{array}$ & $\begin{array}{l}\text { Bathy- } \\
\text { metric } 3 \\
\text { survey }\end{array}$ & $\begin{array}{l}\text { Topo- } \\
\text { graphic } \\
\text { survey }\end{array}$ & $\begin{array}{l}\text { Photo- } \\
\text { graphic } \\
\text { repli- } \\
\text { cations }\end{array}$ & $\begin{array}{l}\text { Surface- } \\
\text { flow } \\
\text { pattern }\end{array}$ & $\begin{array}{l}\text { Water- } \\
\text { surface } \\
\text { slope }\end{array}$ & $\begin{array}{r}\text { Scour } \\
\text { chains }\end{array}$ & $\begin{array}{l}\text { Sedi- } \\
\text { men- } \\
\text { tology }\end{array}$ \\
\hline
\end{tabular}

(DSS) Above Grapevine Rapid (initial survey Howard, 1975)

\begin{tabular}{|c|c|c|c|c|c|c|c|c|c|c|}
\hline \multirow[t]{4}{*}{81.1} & 19 & $05-29-85$ & $\begin{array}{c}44,000 \\
\text { to } \\
46,000\end{array}$ & -- & $\mathbf{x}$ & $x$ & $\mathbf{x}$ & $\cdots$ & -- & -- \\
\hline & & $08-07-85$ & $\begin{array}{c}17,000 \\
\text { to } \\
24,000\end{array}$ & -- & $\mathbf{x}$ & $x$ & $\mathbf{x}$ & -- & -- & -- \\
\hline & & $10-15-85$ & (4) & -- & $\mathbf{x}$ & $x$ & $\mathbf{x}$ & -- &.- & $-\cdots$ \\
\hline & & $01-21-86$ & $\begin{array}{c}12,000 \\
\text { to } \\
18,000\end{array}$ & $\cdots$ & $\mathbf{x}$ & $x$ & $x$ & $\cdots$ & -. & -- \\
\hline
\end{tabular}

Cremation Camp (initial survey Boward, 1975)

\begin{tabular}{|c|c|c|c|c|c|c|c|c|c|c|}
\hline \multirow[t]{5}{*}{87.1} & 20 & $04-21-85$ & $\begin{array}{c}23,800 \\
\text { to } \\
26,300\end{array}$ & $\begin{array}{c}X \\
(2)\end{array}$ & $\cdots$ & -- & $-\cdots$ & -- & -- & $-\cdots$ \\
\hline & & $05-30-85$ & $\begin{array}{c}45,000 \\
\text { to } \\
47,000\end{array}$ & $\cdots$ & -- & -- & -- & $x$ & -- & $-\cdots$ \\
\hline & & $\begin{array}{c}09-05-85 \\
(1355)\end{array}$ & 29,300 & $x$ & -- & $\cdots$ & $\cdots$ & $\cdots$ & $\cdots$ & $\cdots$ \\
\hline & & $01-20-86$ & 17,800 & $x$ & -- & -- & -- & -- & -- & -- \\
\hline & & $\begin{array}{c}(1440) \\
01-21-86 \\
(1150)\end{array}$ & 15,300 & $\mathbf{x}$ & -- & -- & -- & -- & -- & -- \\
\hline
\end{tabular}

(DSS) Ninety-One Mile Creek (original survey)

\begin{tabular}{|c|c|c|c|c|c|c|c|c|c|c|}
\hline 91.0 & 21 & $\begin{array}{l}08-08-85 \\
10-15-85 \\
01-22-86\end{array}$ & $\begin{array}{c}19,000 \\
\text { to } \\
24,000 \\
(4) \\
13,000 \\
\text { to } \\
22,000\end{array}$ & $-\cdots$ & $\begin{array}{l}x \\
x\end{array}$ & $\begin{array}{l}\mathbf{X} \\
\mathbf{X}\end{array}$ & -- & $\bar{x}$ & -- & -- \\
\hline \multicolumn{11}{|c|}{ Trinity Creek } \\
\hline 91.4 & 22 & $\begin{array}{l}08-08-85 \\
01-22-86\end{array}$ & $\begin{array}{c}19,000 \\
\text { to } \\
24,000 \\
13,000 \\
\text { to } \\
22,000\end{array}$ & -.- & -- & $\mathbf{x}$ & -- & $-\cdots$ & -.. & -- \\
\hline
\end{tabular}

See footnotes at end of table. 
Table 1.--Summary of study sites and types of data collected--Continued

\begin{tabular}{|c|c|c|c|c|c|c|c|c|c|c|}
\hline $\begin{array}{l}\text { River } \\
\text { mile }\end{array}$ & $\begin{array}{l}\text { Site } \\
\text { num- } \\
\text { ber }\end{array}$ & $\begin{array}{l}\text { Date and } \\
\text { time of } \\
\text { study } 1\end{array}$ & $\begin{array}{l}\text { Discharge, } \\
\text { in cubic } \\
\text { feet per } \\
\text { second }{ }^{2}\end{array}$ & $\begin{array}{l}\text { Bathy- } \\
\text { metric } \\
\text { survey } 3\end{array}$ & $\begin{array}{l}\text { Topo- } \\
\text { graphic } \\
\text { survey }\end{array}$ & $\begin{array}{l}\text { Photo- } \\
\text { graphic } \\
\text { repli- } \\
\text { cations }\end{array}$ & $\begin{array}{l}\text { Surface- } \\
\text { flow } \\
\text { pattern }\end{array}$ & $\begin{array}{l}\text { Water- } \\
\text { surface } \\
\text { slope }\end{array}$ & $\begin{array}{r}\text { Scour } \\
\text { chains }\end{array}$ & $\begin{array}{l}\text { Sedi- } \\
\text { men- } \\
\text { tology }\end{array}$ \\
\hline
\end{tabular}

(DSS) Granite Rapid (initial survey Howard, 1975; Ferrari, 1987)

\begin{tabular}{|c|c|c|c|c|c|c|c|c|c|c|}
\hline \multirow[t]{3}{*}{$\begin{array}{l}93.1 \\
93.4\end{array}$} & 23 & $\begin{array}{c}05-31-85 \\
\text { to }\end{array}$ & 42,000 & -- & $x$ & --- & $x$ & $x$ & --- & --- \\
\hline & & $\begin{array}{l}06-01-85 \\
08-09-85\end{array}$ & $\begin{array}{c}47,000 \\
18,000 \\
\text { to } \\
22,000\end{array}$ & --- & $x$ & --- & $x$ & --- & --- & --- \\
\hline & & $01-22-86$ & $\begin{array}{c}13,000 \\
\text { to } \\
22,000\end{array}$ & -- & $x$ & --- & $x$ & --- & --- & --- \\
\hline
\end{tabular}

Ninety-Six Mile Camp

\begin{tabular}{|c|c|c|c|c|c|c|c|c|c|c|}
\hline \multirow[t]{2}{*}{96.0} & 24 & $06-01-85$ & $\begin{array}{c}42,000 \\
\text { to }\end{array}$ & --- & --- & $x$ & --- & --- & --- & --- \\
\hline & & $\begin{array}{l}08-09-85 \\
10-16-85\end{array}$ & $\begin{array}{c}47,000 \\
18,000 \\
\text { to } \\
22,000 \\
\text { (4) }\end{array}$ & --- & -- & $x$ & --- & --- & --- & --- \\
\hline
\end{tabular}

(DSS) Boucher Rapid (original survey)

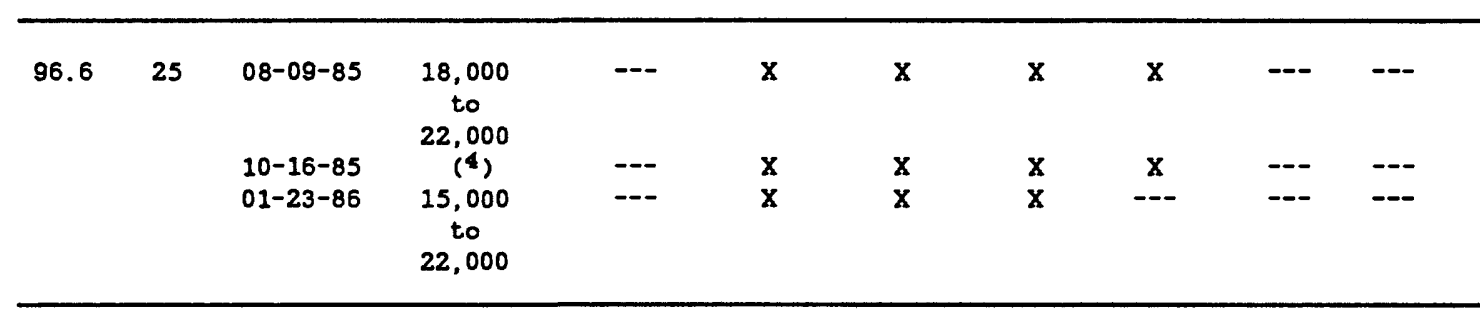

Upper Crystal Rapid

\begin{tabular}{|c|c|c|c|c|c|c|c|c|c|c|}
\hline 98.0 & 26 & $\begin{array}{c}01-22-86 \\
(1610)\end{array}$ & (4) & $\mathrm{x}$ & --- & -- & -- & -- & --- & --- \\
\hline \multicolumn{11}{|c|}{ Elves Chasm (original survey) } \\
\hline 116.0 & 27 & $\begin{array}{l}10-17-85 \\
01-24-86\end{array}$ & $\begin{array}{c}\text { (4) } \\
15,000 \\
\text { to } \\
23,000\end{array}$ & --- & $\begin{array}{l}x \\
x\end{array}$ & $\begin{array}{l}\mathbf{x} \\
\mathbf{x}\end{array}$ & $\begin{array}{l}x \\
x\end{array}$ & --- & --- & --- \\
\hline
\end{tabular}

See footnotes at end of table. 
Table 1.--Sumary of study sites and types of data collected--Continued

\begin{tabular}{|c|c|c|c|c|c|c|c|c|c|c|}
\hline $\begin{array}{l}\text { River } \\
\text { mile }\end{array}$ & $\begin{array}{l}\text { Site } \\
\text { num- } \\
\text { ber }\end{array}$ & $\begin{array}{l}\text { Date and } \\
\text { time of } \\
\text { study } 1\end{array}$ & $\begin{array}{c}\text { Discharge, } \\
\text { in cubic } \\
\text { feet per } \\
\text { second } 2\end{array}$ & $\begin{array}{l}\text { Bathy- } \\
\text { metric } \\
\text { survey } 3\end{array}$ & $\begin{array}{l}\text { Topo- } \\
\text { graphic } \\
\text { survey }\end{array}$ & $\begin{array}{l}\text { Photo- } \\
\text { graphic } \\
\text { repli- } \\
\text { cations }\end{array}$ & $\begin{array}{l}\text { Surface- } \\
\text { flow } \\
\text { pattern }\end{array}$ & $\begin{array}{l}\text { Water- } \\
\text { surface } \\
\text { slope }\end{array}$ & $\begin{array}{r}\text { Scour } \\
\text { chains }\end{array}$ & $\begin{array}{l}\text { Sedi- } \\
\text { men- } \\
\text { tology }\end{array}$ \\
\hline
\end{tabular}

(DSS) One Hundred Twenty Mile Camp (initial survey Ferrari, 1987)

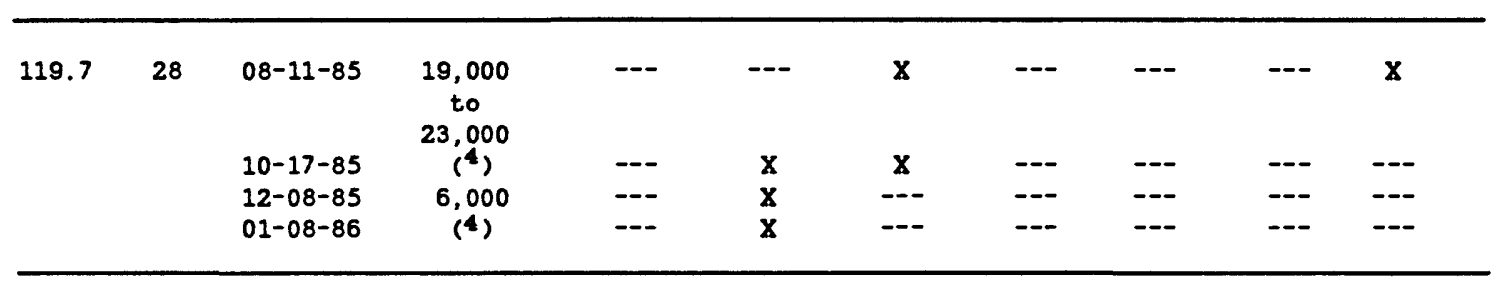

(DSS) Lower Blacktail Rapid (original survey)

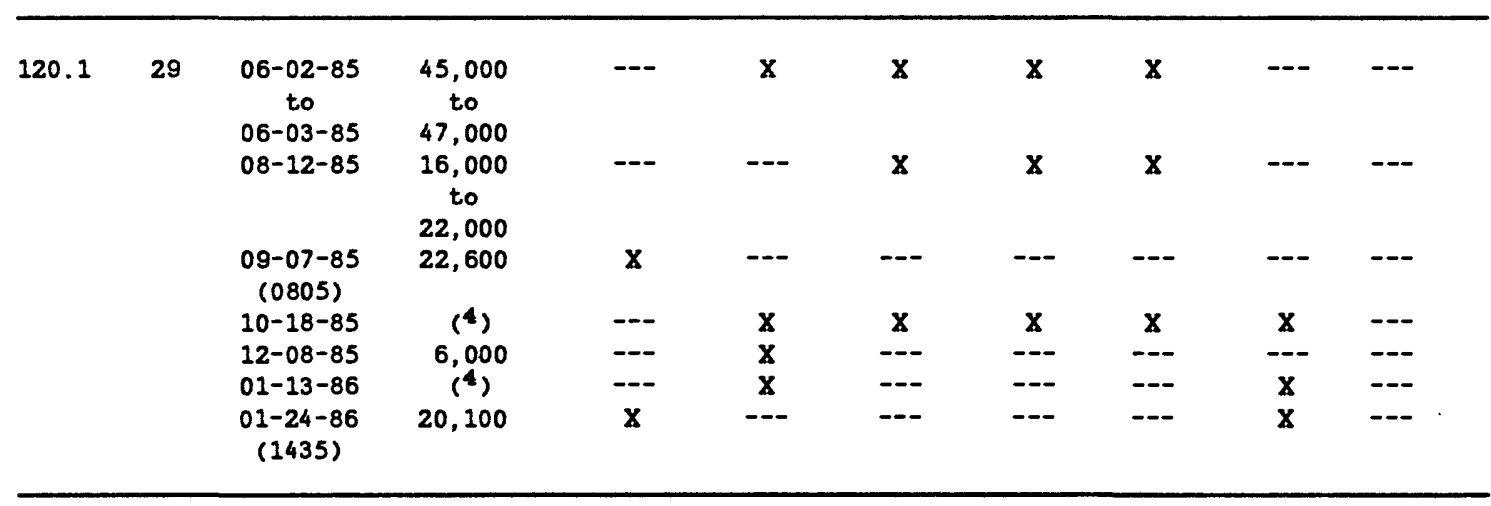

One Hundred Twenty-Two Mile Rapid

\begin{tabular}{|c|c|c|c|c|c|c|c|c|c|c|}
\hline \multirow[t]{2}{*}{121.6} & 30 & $06-05-85$ & $\begin{array}{c}44,000 \\
\text { to } \\
46,000\end{array}$ & --- & --- & $x$ & $\mathbf{x}$ & -- & --- & --- \\
\hline & & $\begin{array}{l}08-13-85 \\
10-18-85 \\
01-26-86\end{array}$ & $\begin{array}{c}19,000 \\
\text { to } \\
23,000 \\
\text { (4) } \\
21,000 \\
\text { to } \\
25,000\end{array}$ & $\begin{array}{l}--- \\
---\end{array}$ & --- & $\begin{array}{l}\mathbf{x} \\
\mathbf{x}\end{array}$ & $\begin{array}{c}x \\
--\end{array}$ & --- & --- & --- \\
\hline
\end{tabular}

(DSS) One Hundred Twenty-Two Mile Creek (original survey)

\begin{tabular}{|c|c|c|c|c|c|c|c|c|c|c|}
\hline \multirow[t]{3}{*}{122.0} & 31 & $06-05-85$ & $\begin{array}{c}44,000 \\
\text { to } \\
46,000\end{array}$ & --- & --- & $x$ & $x$ & --- & --- & $x$ \\
\hline & & $08-13-85$ & $\begin{array}{c}19,000 \\
\text { to } \\
23,000\end{array}$ & $\cdots$ & $x$ & $\mathbf{x}$ & $x$ & $\mathbf{x}$ & --- & --- \\
\hline & & $10-20-85$ & $\begin{array}{c}7,000 \\
\text { to } \\
13,000\end{array}$ & --- & $x$ & $x$ & $x$ & $x$ & -- & $x$ \\
\hline
\end{tabular}

See footnotes at end of table. 
Table 1.--Sumary of study sites and types of data collected--Continued

\begin{tabular}{|c|c|c|c|c|c|c|c|c|c|c|}
\hline $\begin{array}{l}\text { River } \\
\text { mile }\end{array}$ & $\begin{array}{l}\text { Site } \\
\text { num- } \\
\text { ber }\end{array}$ & $\begin{array}{l}\text { Date and } \\
\text { time of } \\
\text { study }\end{array}$ & $\begin{array}{l}\text { Dishcarge, } \\
\text { in cubic } \\
\text { feet per } \\
\text { second }^{2}\end{array}$ & $\begin{array}{l}\text { Bathy- } \\
\text { metric } \\
\text { survey } 3\end{array}$ & $\begin{array}{l}\text { Topo- } \\
\text { Braphic } \\
\text { survey }\end{array}$ & $\begin{array}{l}\text { Photo- } \\
\text { graphic } \\
\text { repli- } \\
\text { cations }\end{array}$ & $\begin{array}{l}\text { Surface- } \\
\text { flow } \\
\text { pattern }\end{array}$ & $\begin{array}{l}\text { Water- } \\
\text { surface } \\
\text { slope }\end{array}$ & $\begin{array}{l}\text { Scour } \\
\text { chains }\end{array}$ & $\begin{array}{l}\text { Sedi- } \\
\text { men- } \\
\text { tology }\end{array}$ \\
\hline \multicolumn{11}{|c|}{ (DSS) One } \\
\hline & & $\begin{array}{l}12-08-85 \\
01-13-86 \\
01-25-86\end{array}$ & $\begin{array}{c}6,000 \\
(4) \\
18,000 \\
\text { to } \\
26,000\end{array}$ & $\begin{array}{l}--- \\
---\end{array}$ & $\begin{array}{l}\mathbf{X} \\
\mathrm{X} \\
\mathrm{X}\end{array}$ & $\bar{x}$ & --- & --- & --- & 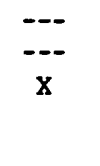 \\
\hline
\end{tabular}

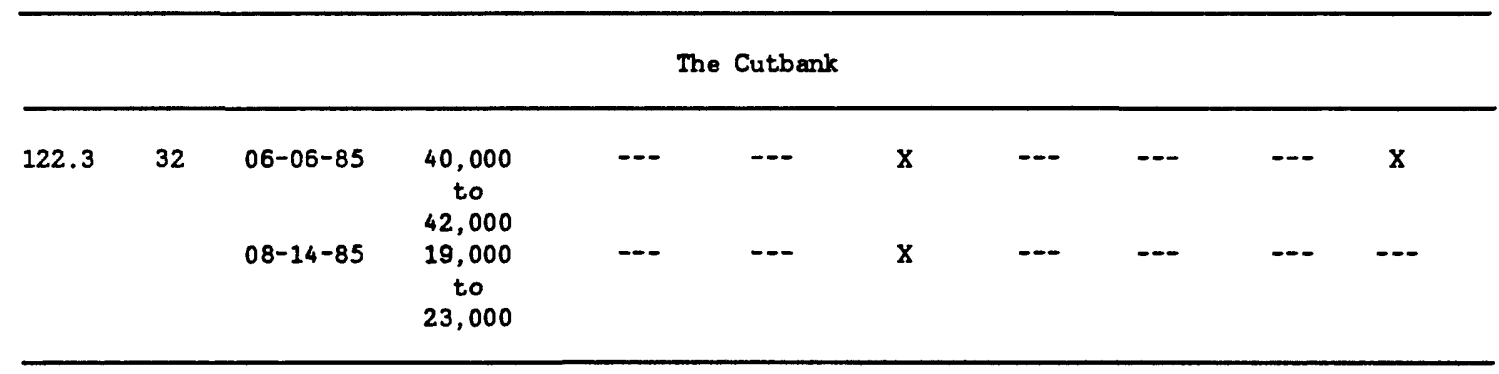

Forster Rapid

\begin{tabular}{|c|c|c|c|c|c|c|c|c|c|c|}
\hline \multirow[t]{2}{*}{122.6} & 33 & $06-06-85$ & $\begin{array}{c}40,000 \\
\text { to } \\
42,000\end{array}$ & -- & -. & $\cdots$ & -- & $x$ & $\cdots$ & $-\cdots$ \\
\hline & & $08-14-85$ & $\begin{array}{c}19,000 \\
\text { to } \\
23,000\end{array}$ & -- & -- & $x$ & -- & -- & -- & -- \\
\hline
\end{tabular}

Enfilade Point (initial survey Ferrari, 1987)

\begin{tabular}{|c|c|c|c|c|c|c|c|c|c|c|}
\hline \multirow[t]{4}{*}{123.5} & 34 & $06-06-85$ & $\begin{array}{c}40,000 \\
\text { to } \\
42,000\end{array}$ & -- & -- & $x$ & $x$ & -- & -- & $-\cdots$ \\
\hline & & $08-14-85$ & $\begin{array}{c}19,000 \\
\text { to } \\
23,000\end{array}$ & -- & -- & $x$ & $x$ & -- & -- & $\cdots$ \\
\hline & & $10-20-85$ & $\begin{array}{c}7,000 \\
\text { to } \\
13,000\end{array}$ & -- & -- & $\mathrm{x}$ & $x$ & -- & -- & -- \\
\hline & & $01-27-86$ & $\begin{array}{c}23,000 \\
\text { to } \\
26,000\end{array}$ & -- & $x$ & $x$ & $x$ & -- & -- & -- \\
\hline
\end{tabular}

Stone Creek

\begin{tabular}{|c|c|c|c|c|c|c|c|c|c|c|}
\hline 131.8 & 35 & $06-08-85$ & $\begin{array}{c}30,000 \\
\text { to } \\
35,000\end{array}$ & -- & --- & $x$ & -- & -- & --- & -- \\
\hline
\end{tabular}

See footnotes at end of table. 
Table 1.--Sumary of study sites and types of data collected--Continued

\begin{tabular}{|c|c|c|c|c|c|c|c|c|c|c|}
\hline $\begin{array}{l}\text { River } \\
\text { mile }\end{array}$ & $\begin{array}{l}\text { Site } \\
\text { num- } \\
\text { ber }\end{array}$ & $\begin{array}{l}\text { Date and } \\
\text { time of } \\
\text { study } 1\end{array}$ & $\begin{array}{l}\text { Discharge, } \\
\text { in cubic } \\
\text { feet per } \\
\text { second }{ }^{2}\end{array}$ & $\begin{array}{l}\text { Bathy- } \\
\text { metric } \\
\text { survey }\end{array}$ & $\begin{array}{l}\text { Topo- } \\
\text { graphic } \\
\text { survey }\end{array}$ & $\begin{array}{l}\text { Photo- } \\
\text { graphic } \\
\text { repli- } \\
\text { cations }\end{array}$ & $\begin{array}{l}\text { Surface- } \\
\text { flow } \\
\text { pattem }\end{array}$ & $\begin{array}{l}\text { Water- } \\
\text { surface } \\
\text { slope }\end{array}$ & $\begin{array}{l}\text { Scour } \\
\text { chains }\end{array}$ & $\begin{array}{l}\text { Sedi- } \\
\text { men- } \\
\text { tology }\end{array}$ \\
\hline \multicolumn{11}{|c|}{ Stone Creek--Continued } \\
\hline & & $\begin{array}{l}08-15-85 \\
10-20-85\end{array}$ & $\begin{array}{c}20,000 \\
\text { to } \\
24,000 \\
(4)\end{array}$ & -- & -- & $\begin{array}{l}x \\
x\end{array}$ & -- & -- & --- & -- \\
\hline \multicolumn{11}{|c|}{ Opposite Deer Creek Falls } \\
\hline 136.2 & 36 & $08-15-85$ & $\begin{array}{c}20,000 \\
\text { to } \\
24,000\end{array}$ & -- & -- & $x$ & -- & -- & $\cdots$ & -- \\
\hline
\end{tabular}

(DSS) National Rapid (original survey)

\begin{tabular}{|c|c|c|c|c|c|c|c|c|c|c|}
\hline \multirow[t]{8}{*}{166.5} & 37 & $04-25-85$ & $\begin{array}{c}16,800 \\
\text { to } \\
20,800\end{array}$ & $\begin{array}{c}X \\
(3)\end{array}$ & $\cdots$ & $\ldots$ & $x$ & $x$ & -- & -- \\
\hline & & $\begin{array}{c}06-09-85 \\
\text { to } \\
06-11-85\end{array}$ & 30,000 & -- & $x$ & $x$ & $x$ & $x$ & -- & $x$ \\
\hline & & $\begin{array}{c}09-09-85 \\
(1010)\end{array}$ & 22,200 & $x$ & -- & -- & -- & -- & -- & -- \\
\hline & & $\begin{array}{c}09-10-85 \\
(1000)\end{array}$ & 21,200 & $x$ & --- & -- & $\cdots$ & -- & -- & -- \\
\hline & & $\begin{array}{c}10-21-85 \\
\text { to } \\
10-22-85\end{array}$ & $\begin{array}{c}8,000 \\
\text { to } \\
17,000\end{array}$ & --- & $x$ & $x$ & $x$ & $\mathrm{x}$ & -- & $\ldots$ \\
\hline & & $01-08-86$ & $\left(^{4}\right)$ & -- & $x$ & -- & -- & -- & $\ldots$ & -- \\
\hline & & $\begin{array}{c}01-27-86 \\
(1255)\end{array}$ & 21,100 & $x$ & --- & -- & -- & --- & -- & -- \\
\hline & & $\begin{array}{c}01-28-86 \\
(1615)\end{array}$ & 23,100 & $\begin{array}{c}x \\
(2)\end{array}$ & $x$ & $\mathrm{X}$ & $x$ & --- & --- & -- \\
\hline
\end{tabular}

(DSS) Fern Glen Rapid (Ferrari, 1987)

\begin{tabular}{|c|c|c|c|c|c|c|c|c|c|c|}
\hline 168.0 & 38 & $\begin{array}{l}01-08-86 \\
01-30-86\end{array}$ & $\begin{array}{c}(4) \\
16,000 \\
\text { to } \\
23,000\end{array}$ & --- & $\begin{array}{l}x \\
x\end{array}$ & --- & $x$ & $x$ & --- & --- \\
\hline
\end{tabular}

See footnotes at end of table. 
Table 1. - Summary of study sites and trpes of date collected--Continued

\begin{tabular}{|c|c|c|c|c|c|c|c|c|c|c|}
\hline $\begin{array}{l}\text { Rivar } \\
\text { mile }\end{array}$ & $\begin{array}{l}\text { Site } \\
\text { num- } \\
\text { ber }\end{array}$ & $\begin{array}{l}\text { Date and } \\
\text { time of } \\
\text { atudy } 1\end{array}$ & $\begin{array}{l}\text { Discherge, } \\
\text { in cubic } \\
\text { feet per } \\
\text { second } 2\end{array}$ & $\begin{array}{l}\text { Bathy- } \\
\text { motric } \\
\text { aurvers }\end{array}$ & $\begin{array}{l}\text { Topo- } \\
\text { sraphic } \\
\text { survoy }\end{array}$ & $\begin{array}{l}\text { Photo- } \\
\text { graphic } \\
\text { ropli- } \\
\text { cations }\end{array}$ & $\begin{array}{l}\text { Surface- } \\
\text { flow } \\
\text { pattern }\end{array}$ & $\begin{array}{l}\text { Water- } \\
\text { surface } \\
\text { slope }\end{array}$ & $\begin{array}{l}\text { Scour } \\
\text { chains }\end{array}$ & $\begin{array}{l}\text { Sedi- } \\
\text { tolog- }\end{array}$ \\
\hline
\end{tabular}

One Bundred Eighty-Six Mile

\begin{tabular}{|c|c|c|c|c|c|c|c|c|c|c|}
\hline \multirow[t]{5}{*}{185.8} & 39 & $\begin{array}{c}04-27-85 \\
(1410)\end{array}$ & 22,300 & $\mathbf{x}$ & -- & -- & -- & -- & $-\infty$ & $\cdots$ \\
\hline & & $06-12-85$ & 30,000 & -- & $-\infty$ & --- & $\mathbf{x}$ & $\mathbf{x}$ & -- & -- \\
\hline & & $\begin{array}{c}09-11-85 \\
(1040)\end{array}$ & 26,000 & $x$ & -- & -- & $-\infty$ & $-\infty$ & $-\infty$ & - \\
\hline & & $\begin{array}{c}09-12-85 \\
(0825)\end{array}$ & 26,000 & $x$ & -- & $\cdots$ & -- & -- & $-\infty$ & $\cdots$ \\
\hline & & $\begin{array}{c}01-29-86 \\
(1545)\end{array}$ & 19,400 & $\mathbf{x}$ & -- & -- & -- & -- & -- & - \\
\hline
\end{tabular}

(DSS) Pumpkin Springs (original survey)

\begin{tabular}{|c|c|c|c|c|c|c|c|c|c|c|}
\hline \multirow[t]{7}{*}{212.9} & 40 & $\begin{array}{c}04-29-85 \\
(0835)\end{array}$ & 26,200 & $x$ & -- & -- & -- & -- & $\cdots$ & $\cdots$ \\
\hline & - & $06-13-85$ & $\begin{array}{c}30,000 \\
\text { to } \\
35,000\end{array}$ & $\cdots$ & $x$ & $x$ & $x$ & $x$ & $\cdots$ & $x$ \\
\hline & & $08-16-85$ & $\begin{array}{c}20,000 \\
\text { to } \\
22,000\end{array}$ & -- & $x$ & $x$ & $x$ & $x$ & $\cdots$ & $x$ \\
\hline & & $\begin{array}{c}09-13-85 \\
(0915)\end{array}$ & 25,200 & $x$ & $\cdots$ & $\cdots$ & $\cdots$ & -- & -- & $\cdots$ \\
\hline & & $10-23-85$ & $\begin{array}{c}7,000 \\
\text { to } \\
16,000\end{array}$ & -- & $x$ & $x$ & $x$ & -- & -- & $\cdots$ \\
\hline & & $\begin{array}{c}01-30-86 \\
(1545)\end{array}$ & 25,900 & $x$ & -- & $\cdots$ & -- & $\cdots$ & $\cdots$ & $\cdots$ \\
\hline & & $\begin{array}{c}01-31-86 \\
(0915)\end{array}$ & 21,400 & $x$ & $x$ & $x$ & $x$ & $x$ & $\cdots$ & $x$ \\
\hline
\end{tabular}

Diamond Croek

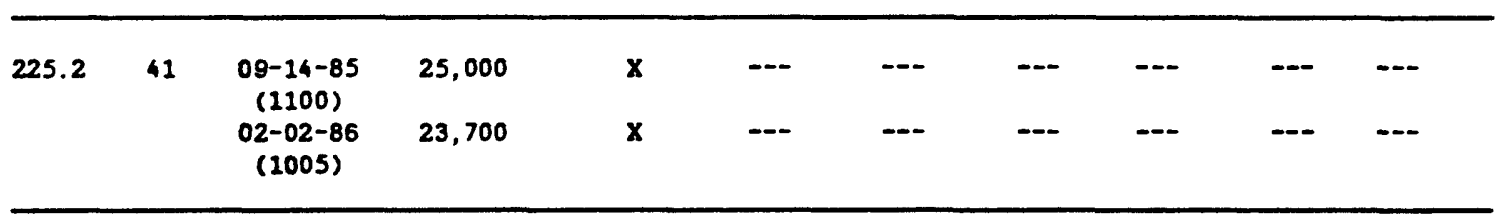

1Iimes listed are for bathymetric surveys.

2Estimated discharge during bathymetric surveys or range of discharga at nearest gaging station durins day of work.

3 Nimber is actual number of surveys.

Unit-value data not available. 


\section{Acknowledgments}

The fieldwork accomplished in this project was the direct result of the work of many individuals. Volunteers with the U.S. National Park Service or the U.S. Geological Survey included Bernard O. Bauer, James Harris, Robert Jacobsen, Catherine Hooper, Barbara Rusmore, and John Rusmore. Thanks go to them all as well as to the other field assistants. Dave Steinke made modifications to the equipment used for bathymetric surveys that made those surveys possible. Martha Hahn of the National Park Service arranged for the appointment of volunteers for the National Park Service and obtained unpublished data for our use. Boatmen for the raft trips were Jon Stoner, Stuart Reeder, Bob Grusy, and Owen Baynham; their skilled navigation and professionalism made all our work possible.

\section{TERMINOLOGY}

Flow separation and associated secondary circulations are characteristic hydraulic conditions in the Grand Canyon and determine sand-deposit location and extent of change. The phenomenon of flow separation at abrupt channel expansions or contractions is described in basic fluid mechanics texts. When flow separation occurs, the main downstream current becomes separated from the channel banks and areas of recirculating flow exist between the downstream current and the banks (fig. 3). These recirculation zones are composed of one or more eddies, a term denoting "any rotating fluid motion which possesses continuity so long as the flow pattern which creates it continues to prevail" (Matthes, 1947). Eddies, as discussed in this report, have a vertical or nearly vertical axis of rotation. Typically, a recirculation zone has a primary eddy and may have a secondary eddy. That portion of the primary eddy where flow is directed upstream and toward the main downstream current is referred to as the primary-eddy return current. The bed of the recirculation zone excavated by this current is termed the primary-eddy return-current channel. Other portions of recirculation zones are not organized into a rotation. Current directions in these low-velocity areas may have a preferential direction, may oscillate in several directions, or may be virtually stagnant. In summary, flow separation leads to the existence of recirculation zones. These zones are composed of one or more eddies and low-velocity areas.

The point at which downstream-directed flow becomes detached from the channel banks is called the separation point (fig. $3 A$ ). The point at which downstream-directed flow is again adjacent to the banks is called the reattachment point. The separation point is the most upstream point of the recirculation zone, and the reattachment point is at the most downstream point of the recirculation zone. On the Colorado River, these points are actually zones, 5-20 ft wide, within which separation or reattachment point may migrate. A plane and its surface expression, the separation surface, divides the main downstream-directed flow from the recirculation zone. 


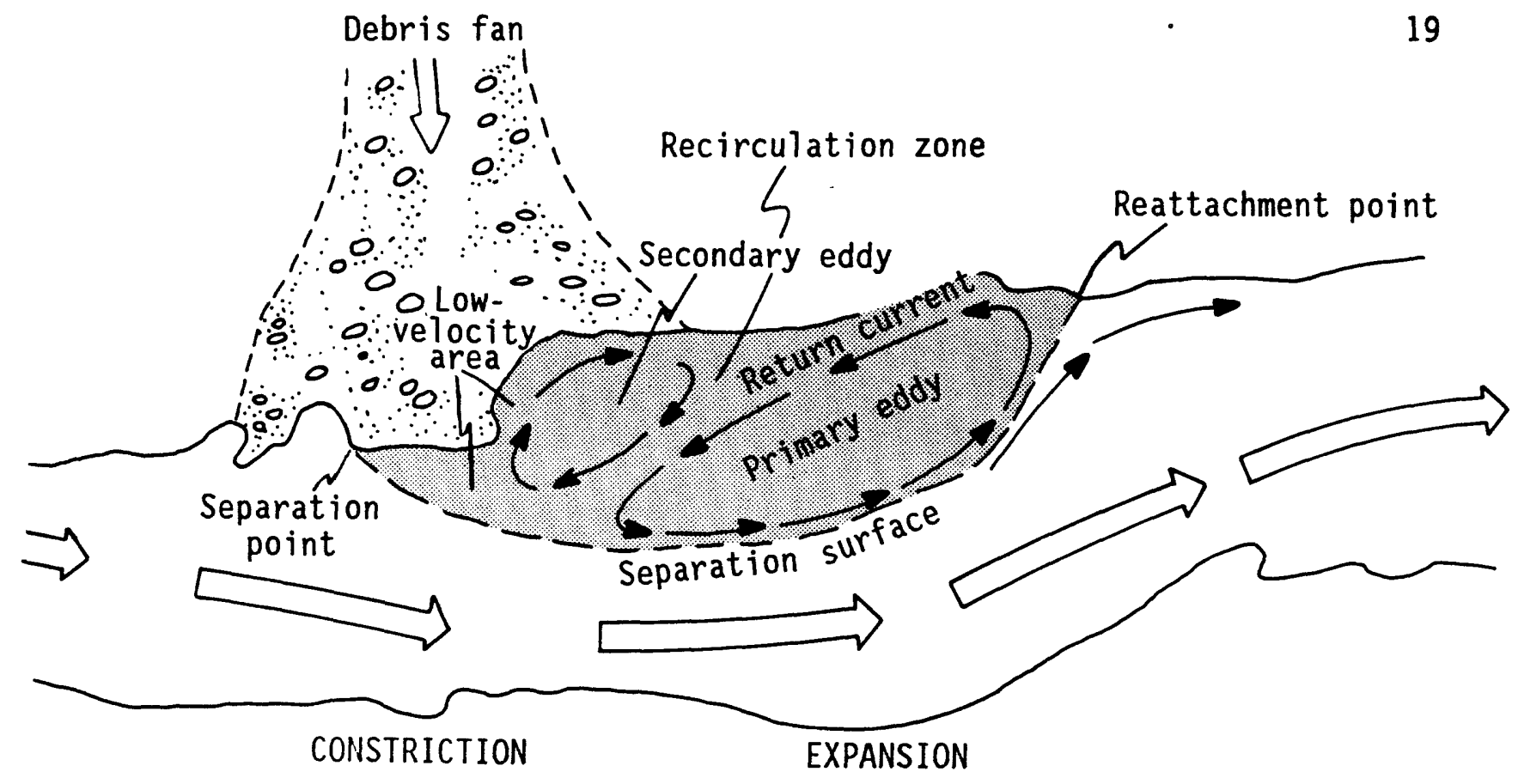

A.

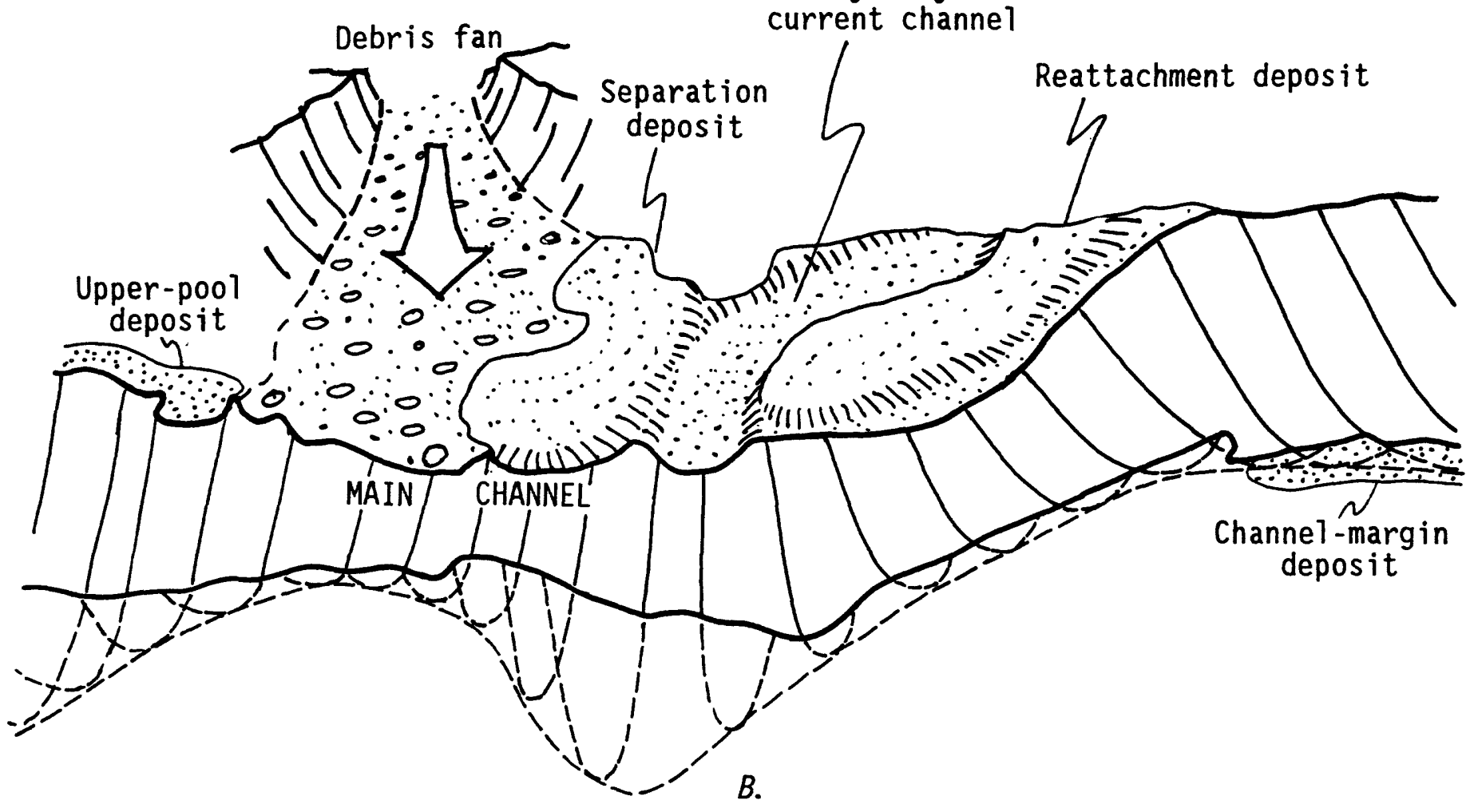

Figure 3.--Flow patterns and configuration of bed deposits in a typical recirculation zone. $A$, Flow patterns. $B$, Configuration of bed deposits. 
Two types of alluvial sand deposits within recirculation zones are highest in elevation and are of most interest to whitewater boaters and campers. Separation deposits, the first type, mantle the downstream part of debris fans and are located near the separation point. Reattachment deposits, the second type, are located at the downstream end of recirculation zones, project upstream into the center of the zones, and are near the reattachment point (fig. 3B). At places, the surface of separation and reattachment deposits merge and the deposits cannot be distinguished solely on the basis of location, although they each have distinctive sedimentary characteristics. At other places, one or the other may not be found in a particular recirculation zone.

Alluvial sand deposits are also typically located upstream from constrictions. At least the lower part of many of these upper-pool deposits is a reattachment deposit associated with small recirculation zones. The higher parts of these same deposits, however, resemble terraces. Where the origin of alluvial deposits could not be determined on the basis of planimetric shape or location, they are called channel-margin deposits. Point-bar deposits, which are characteristic of alluvial meandering rivers, are found infrequently in the park and are not discussed.

Abrupt changes in flow area cause flow separation. In the Grand Canyon, the channel is typically more narrow and shallow around obstructing debris fans, and this short reach is called the constriction. Downstream from the debris fan, a short reach is wider than the average channel width and is called the expansion. Downstream from the expansion, the channel typically resumes the dimensions characteristic of the reach upstream from the constriction. The separation point typically is located near the transition from constriction to expansion. Recirculation zones occur in the expansion.

The ratio of channel width at the constriction to average upstream channel width is termed the constriction ratio. The ratio of channel width at the expansion to channel width at the constriction is termed the expansion ratio. The term elevation used in this report refers to the distance above or below either an arbitrary local datum or sea level.

\section{METHODS OF ANALYSIS}

Between April 1985 and February 1986, sand-deposit change was measured by repeated topographic and bathymetric surveys. These surveys, as well as photographs taken between April and February, were compared with similar types of data collected between 1965 and 1984 in order to measure change over longer time periods. Reference marks established by Howard (1975), Laursen and Silverston (1976), or Ferrari (1987) were used. At new study sites, networks of reference marks were established.

A theodolite distance meter and standard techniques were used for most topographic surveys. About 25 percent of the topographic surveys were made using a hand level and tape. Surveys were made along profile lines, and topographic maps of most sites were made. 
Resurvey of reference-mark networks generally differed by less than $0.10 \mathrm{ft}$ from survey to survey. Surveying data were initially plotted in plan view to insure that repeated surveys matched. Where they did not, surveying data were adjusted for differences in position on the basis of surveying data of surrounding topography. This technique resulted in accurate depiction of topographic change along specific profile lines. Differences in elevation exceeding $0.25 \mathrm{ft}$ are considered to be significant in this study.

Bathymetric surveys were made from a raft about $35 \mathrm{ft}$ long by using a recording echo-depth sounder and a local microwave positioning system. The positioning system consisted of two remote units mounted on tripods on shore, a master unit mounted on a mast on the raft, and the electronics that control their operation. The distance between the master and each remote is determined by the traveltime of microwaves. The position of the remotes in the local coordinate system was determined by their location in relation to fixed reference marks, and the position of the raft at any time was computed from the known distances between the master unit and each remote. Data from the positioning system and the depth sounder were recorded along with time on a data logger as the raft moved about the study area. Time interval for recording could be changed but generally was 2 seconds. Depths were converted to elevation by reference to elevation of the water surface during the survey. Maps of the data were plotted and contours were drawn by use of a computer-contouring system.

Precision of the recording echo-depth sounder used is $0.1 \mathrm{ft}$, and accuracy is 0.5 percent of the measured depth or about $0.25 \mathrm{ft}$ at a depth of $50 \mathrm{ft}$. Although maximum depth was 70 to $80 \mathrm{ft}$ at a few study sites, maximum depth was less than $50 \mathrm{ft}$ at most sites. Water-surface elevation during each survey was monitored either by a temporary recording-stage gage or by periodic reading of a staff gage on shore. Water-surface elevation changed with time during surveys and at a given time was different in different parts of the surveyed area. Change with time was caused primarily by discharge fluctuations or surface waves. During the bathymetric survey, the edge of water was mapped using standard surveying techniques. Depth changes in excess of $0.5 \mathrm{ft}$ are considered significant.

Spurious depths were recorded when air entrained in the water column caused the signal to reflect within the water column rather than off the channel bottom. Spurious numbers in the data set, which were identified by comparing the stored numbers with depths recorded graphically, generally showed shallower depths than preceding or following measurements. In some cases, the amount and areal extent of entrained air severely limited the area that could be surveyed, especially downstream from rapids.

Uncertainty of the distance measurement by each microwave unit is about $3 \mathrm{ft}$. Uncertainty of the raft position computed from the two distances depends mainly on the uncertainty of the distance measurement and on the relative positions of the master and remote units. Highest position accuracy (about $4.3 \mathrm{ft}$ ) is obtained when the master and remotes form a $90^{\circ}$ angle. The accuracy decreases as the angle increases or decreases from $90^{\circ}$, and is about $11.7 \mathrm{ft}$ at angles of $30^{\circ}$ and $150^{\circ}$. Remotes were located near the center of the recirculation zone or channel 
in such a way as to maintain a line of sight and to give as close to a $90^{\circ}$ angle as possible over the survey area. The uncertainty of position ranges from the minimum of about $4.3 \mathrm{ft}$ to about $20 \mathrm{ft}$.

Data points from the positioning system were used to generate a grid of equally spaced values that were in turn used in graphical fitting of contours for computer plotting. Error of the grid was determined by computing the elevation at data locations by linear interpolation from the values at the grid nodes and comparing the calculated value with the measured value. The method of grid generation was selected to minimize interpolation error while maintaining a reasonable amount of smoothing of the data. Uncertainty in the position of contours also depended on the spatial distribution of data points. Where data points were sparse, contour position was extremely uncertain even though the interpolation error was low.

The resulting uncertainty in the bathymetric maps is the sum of errors in microwave system location, computer contouring, and data-point density. The most significant of these is the uncertainty in raft position caused by poor geometry of the master and remote units and sparse distribution of data points. Although no quantitative measure of the map uncertainty was developed, a qualitative judgement was made for each map and areas judged to have uncertainty too high for meaningful analysis were omitted.

Analys is of sand-deposit change at 13 detailed-study sites since 1965 relied mainly on photographic comparisons. Aerial photography is available for 1965 (U.S. Geological Survey, scale about 1:15,000), 1973 (U.S. Geological Survey, scale about $1: 7,200$ ), and 1984 (U.S. Bureau of Reclamation, scale about $1: 3,000)$. Daily mean discharge varied from 23,100 to $41,200 \mathrm{ft}^{3} / \mathrm{s}$ during the photographic survey of 1965 ; from 5,930 to $12,100 \mathrm{ft}^{3} / \mathrm{s}$ during the survey of 1973 ; and from 5,220 to $5,810 \mathrm{ft}^{3} / \mathrm{s}$ during the survey of 1984. Topographic changes at study sites were determined by measuring the area of exposed sand above the stage corresponding to a discharge of about $25,000 \mathrm{ft}^{3} / \mathrm{s}$. Area of exposed sand was directly measured in the photographs of 1965 for study sites where discharge was about $25,000 \mathrm{ft}^{3} / \mathrm{s}$. Estimates of the shoreline corresponding to a discharge of about $25,000 \mathrm{ft}^{3} / \mathrm{s}$, however, had to be made for the 1973 photography. The upper limit of unvegetated sand on the photographs of 1973 was determined to be associated with a stage of approximately $25,000 \mathrm{ft}^{3} / \mathrm{s}$ by comparing topographic surveys and stage-discharge relations at Eighteen Mile Wash and opposite Nineteen Mile Canyon. Below this stage, sand was swept clean by daily fluctuations. The location of the shoreline at discharges of approximately $25,000 \mathrm{ft}^{3} / \mathrm{s}$ was mapped in the field in August 1985 and drawn on 1984 photographs. A zoom transfer scope was used to adjust for differing scales of each aerial photograph survey. A planimeter was used to measure areas for different years, and differences in area of more than 10 percent were considered significant. 
Measurements of exposed sand deposits at a discharge of about $6,000 \mathrm{ft}^{3} / \mathrm{s}$ were also made for 1973 and 1984 at about 180 sites. Measurements were made directly on aerial photographs. Accuracy of comparisons of exposed sand area is limited by the different scales of different aerial photographs as well as by the changing scale of each particular year's flight. For example, the ratio of scale difference between a unit area on the 1973 and 1984 photographs varied between 5.0 and 7.7, depending on location. In order to compensate for the errors resulting from varying scale, scale ratios were measured at about 1-mile intervals. Areas of deposits in 1973 were estimated by multiplying the area measured on the aerial photographs times the scale ratio so that comparison could be made with areas measured on the 1984 photographs. Areas in 1973 were estimated to be within a range determined by the highest and lowest scale ratios within about $10 \mathrm{mi}$ of the measured site. Areas on 1984 aerial photographs were considered to be accurate to \pm 10 percent. Significant change was considered to have occurred if the estimated 1973 area was entirely beyond the range of the 1984 area estimate.

An inventory of the presence or absence of different types of alluvial sand deposits in 399 recirculation zones was also conducted between river miles 0 and 118 using 1973 and 1984 photography. Criteria used in this inventory are described in the section entitled "changes in Alluvial Sand Deposits, 1973-84."

Other methods used to interpret or document topographic changes or hydraulic conditions included scour chains, sedimentologic descriptions, water-surface slope surveys, and mapping of surface currents. Chains $2 \mathrm{ft}$ long and having links of about $0.1 \mathrm{ft}$ were inserted verticaliy into sand deposits along lines that were roughly perpendicular to shore. A metal detector was used to recover the chains; recovery was about 90 percent. Trenches were dug into sand deposits to reveal sedimentary structures. The size of trenches was limited by the time and equipment available. The largest trench was $80 \mathrm{ft}$ long and $4 \mathrm{ft}$ deep at Fern Glen Rapid.

Surveys of water-surface slope were obtained by measuring the water-surface elevation at the edge of water. A staff gage was installed before each measurement, and observed fluctuations in stage were recorded. All surveyed points were located on aerial photographs along with the survey time. The water-surface survey was adjusted to compensate for measured stage changes. In order to decrease the length of time of the survey and therefore the stage changes during the survey, two rod persons usually were used.

The direction of surface currents and location of shorelines were observed from the shore and mapped on aerial photographs. Uncertainty in position of features near the center of the channel is estimated to be about 5 percent of local river width. Noted features such as the location of separation and reattachment points along the shoreline are accurate to within $10 \mathrm{ft}$. 
BACKGROUND

\section{Physical and Hydraulic Characteristics of the Channel}

The Colorado River channel is in bedrock or bordered by large talus blocks for most of the $225 \mathrm{mi}$ from Lees Ferry to Diamond Creek. Geomorphic characteristics of the river channel are controlled by bedrock type and structure (Dolan and others, 1978). Channel width and depth, presence of midchannel gravel bars, and the distribution of tributary debris fans are all related to the bedrock geology (Howard and Dolan, 1981).

Eleven reaches of the Colorado River were defined on the basis of type of bedrock exposed at river level, average channel top width, average channel width/depth ratio, reach slope, and relation to major tributaries (table 2; and fig. 4). The narrow reaches are Upper Granite Gorge, Aisles, Middle Granite Gorge, Muav Gorge, Supai Gorge, Redwall Gorge, and Lower Granite Gorge. The wide reaches are the Permian Section, Lower Marble Canyon, Furnace Flats, and the Lower Canyon.

Elevation of the river decreases about 1,780 ft between Lees Ferry and Diamond Creek. The descent is accomplished primarily in short steep reaches, many of which are the famous rapids of the Grand Canyon. In the first $150 \mathrm{mi}$ downstream from Lees Ferry, 50 percent of the totai decrease in elevation takes place in only about 9 percent of the distance (Leopold, 1969). Although the average gradient between Lees Ferry and Diamond Creek is 0.0015 , the gradient of many short reaches exceeds 0.01 .

Water-surface slope is low in reaches between rapids, and many reaches have a gradient of 1 ess than 0.0005 (Birdseye, 1923). Water-surface slope flattens in pools upstream from most major rapids, and mean velocity commonily is less than $3 \mathrm{ft} / \mathrm{s}$. A deep scour hole is present immediately below most rapids (Leopold, 1969; Howard and Dolan, 1981; Wilson, 1986).

Rapids are commonly located where the channel has been constricted by alluvial fans formed by debris-flow deposits at the mouths of short, steep tributaries (fig. 3 ). Debris from these flows also increases local bed elevation of the channel. Kieffer (1985) determined constriction ratios at 54 debris fans in the Grand Canyon, using 1973 aerial photography. She found that the ratio ranged from about 0.3 to about 0.7 , and averaged about 0.5 . Because discharge in the 1973 air photos ranged from about 4,000-15,000 fts/s (fig. 4) and constriction ratio might vary with discharge and stage, constriction ratios were recomputed from 1984 photography. The mean constriction ratio at the same debris fans measured by Kieffer (1985) was 0.49 , indicating that while individual sites might vary in relation to stage and method of measurement, when averaged over a number of sites, the effect of stage on constriction ratios is not significant. Because alluvial deposits large enough to be used as campsites are associated with small debris fans as well as the large fans measured by Kieffer (1985), constriction ratios were computed from 1984 photographs for 70 debris fans associated with alluvial deposits inventoried as campsites (Brian and Thomas, 1984) 
Iablo 2. - Characteristics of the renches within the study eren

\begin{tabular}{|c|c|c|c|c|c|c|c|c|}
\hline Reach & $\begin{array}{c}\text { Local anech of } \\
\text { reach }\end{array}$ & $\begin{array}{l}\text { Major seolosic } \\
\text { units ot fiver } \\
\text { level }\end{array}$ & $\begin{array}{l}\text { Description } \\
\text { of roach } \\
\text { width }\end{array}$ & $\begin{array}{l}\text { Avorase } \\
\text { ratio of } \\
\text { top width } \\
\text { to } \operatorname{mos} \\
\text { dopth } 2\end{array}$ & $\begin{array}{l}\text { Average } \\
\text { chemel } \\
\text { width, } \\
\text { in foot }\end{array}$ & $\begin{array}{l}\text { Chermel } \\
\text { slopes }\end{array}$ & $\begin{array}{l}\text { Number } \\
\text { of cemp- } \\
\text { sites per } \\
\text { atlos }\end{array}$ & $\begin{array}{l}\text { Type of ellerviel } \\
\text { sand doposit } \\
\text { topically usod } \\
\text { as cempeites }\end{array}$ \\
\hline $0-11.3$ & $\begin{array}{l}\text { Pormion } \\
\text { Soction }\end{array}$ & $\begin{array}{l}\text { Kaibab Limestone } \\
\text { Ioroweap Formation } \\
\text { Coconino Sandstone } \\
\text { Eormit Shale }\end{array}$ & Hide & 11.7 & 280 & 0.00099 & 0.4 & Soparation \\
\hline $11.0-22.5$ & Supal Gorge & Supal Group & Narron & 7.7 & 210 & .0014 & .9 & Soparation \\
\hline $22.6-35.8$ & Rodmall Corge & Recwall Limestone & Farrow & 9.0 & 220 & .0015 & .9 & Soparation \\
\hline $40.0-61.5$ & $\begin{array}{l}\text { Lower Marble } \\
\text { Canyon }\end{array}$ & $\begin{array}{l}\text { Muav Limestone } \\
\text { Bright Angel Shale } \\
\text { Iapeats Sendstone }\end{array}$ & Wido & 19.1 & 350 & .0010 & 2.6 & $\begin{array}{l}\text { Soparation; } \\
\text { reottacheont }\end{array}$ \\
\hline $61.6-77.4$ & Furnace Flats & $\begin{array}{l}\text { Tapeats Sendstone } \\
\text { Unker Group }\end{array}$ & W1do & 26.6 & 390 & .0021 & 2.5 & Channel marsin \\
\hline $77.5-317.8$ & $\begin{array}{l}\text { Upper Grenitte } \\
\text { Gorge }\end{array}$ & $\begin{array}{l}\text { Zoroaster Plutonic } \\
\text { Complex } \\
\text { Irinity and Elvas } \\
\text { Chasm Grolsses } \\
\text { Vishou Schist }\end{array}$ & Marrow & 7 & 190 & .0023 & .6 & $\begin{array}{l}\text { Soparation; } \\
\text { chamol Eargin }\end{array}$ \\
\hline $117.8-125.5$ & Aisles & $\begin{array}{l}\text { Tapeats Smdstono } \\
\text { Vishnu Sch1st }\end{array}$ & Marrom & 11 & 230 & .0017 & 3.9 & $\begin{array}{l}\text { Roattachent; } \\
\text { chamol marsin; } \\
\text { soparation }\end{array}$ \\
\hline $125.6-138.8$ & $\begin{array}{l}\text { Middle Granite } \\
\text { Gorge }\end{array}$ & $\begin{array}{l}\text { Tapeats Sendstono } \\
\text { Unkar Group } \\
\text { Vishnu Sch1 st }\end{array}$ & Nerrom & 8.2 & 210 & .0020 & 2.3 & Chomol mergin \\
\hline $140-159.8$ & Munv Garze & Muav Limestoose & Marrom & 7.8 & 180 & .0012 & 1.1 & Chemnol masin \\
\hline $160-213.8$ & Lomer Curyon & $\begin{array}{l}\text { Basalt } \\
\text { Muev Limestone } \\
\text { Bright Angel Shalle }\end{array}$ & Wide & 16.1 & 310 & .0013 & 2.4 & - \\
\hline $213.8-225$ & $\begin{array}{l}\text { Lower Granite } \\
\text { Gorse }\end{array}$ & Vishnu Schist & Narrow & 8.1 & 240 & .0016 & 2.3 & - \\
\hline
\end{tabular}

\footnotetext{
${ }^{1}$ Modified fros Grand Canyon Neturel Bistory Association, 1976.

${ }^{2}$ At $24,000 \mathrm{ft}^{3} / \mathrm{s}$, everage based on cross-sect100 date from Perberton and Rendle (1987); cross sectfons at about 1-mile intervals.

3 Based on predicted water-surface elevations at $24,000 \mathrm{ft}^{3} / \mathrm{s}$ (Pemberton and Rendle, 1987).

4 Campsites inventoried by Brian and Thomas (1984).
}

between river miles 0 and 61 . The mean constriction ratio of these sites was 0.54 , somewhat greater than the sample population of Kieffer (1985). The expansion ratio at the 70 sites ranged from 1.3 to 7.3 , with a mean of 2.9. At 59 of these sites where channel-depth data (Wilson, 1986) are available, channel depth at the constriction decreased to as much as 0.30 of the upstream depth and increased in the expansion to as much as nine times the constriction depth.

At most constrictions, recirculation zones exist at discharges between 4,000 and 45,000 $\mathrm{ft}^{3} / \mathrm{s}$. Recirculation-zone size, however, is not constant. At most sites, recirculation zones increase in length with 


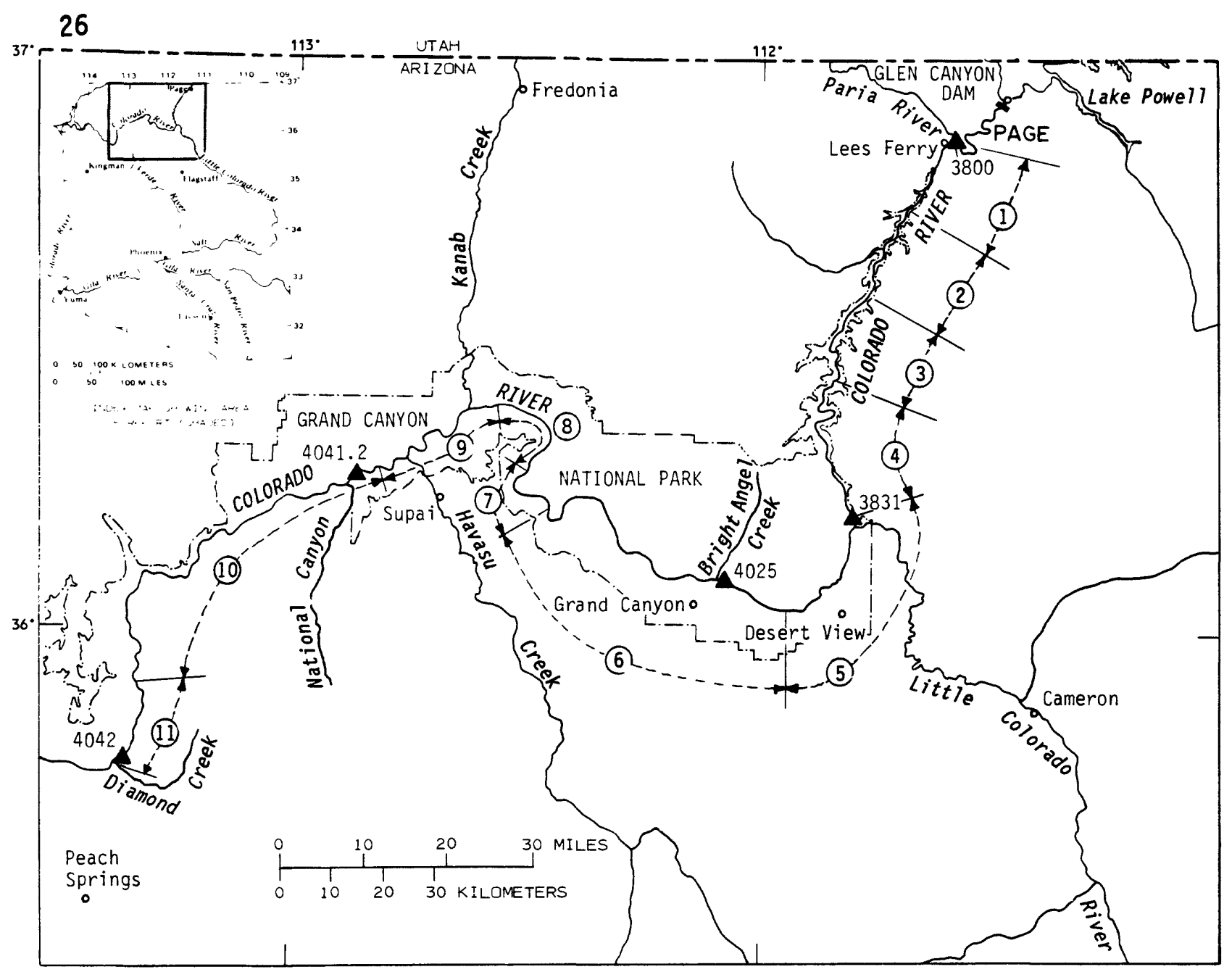

EXPLANATION

(1) PERMiAn SECtion

(2) SUPAI GORGE

(3) REDWALL GORGE

(4) LoWER MaRble canYoN

(5) furnace flats

(6) UPPER GRANITE GORGE

(7) AISLES

(8) MIDDLE GRANITE GORGE

(9) MUAV GORGE

(10) LOWER CANYON

(1i) LOWER GRANITE GORGE

Figure 4.--Reaches within the study area. 
increasing discharge at least to $45,000 \mathrm{ft}^{3} / \mathrm{s}$ (Schmidt, 1986). At Badger Creek Rapid, the separation point is farther upstream and the reattachment point farther downstream at a discharge of $44,000 \mathrm{ft}^{3} / \mathrm{s}$ than at a discharge of $5,600 \mathrm{ft}^{3} / \mathrm{s}$ (fig. 5). At extremely low flow, many recirculation zones are greatiy reduced in size, and the bed of the recirculation zone may be completely exposed. For example, at Soap Creek Rapid, flow separation does not occur at discharges less than about $5,000 \mathrm{ft}^{3} / \mathrm{s}$.

At each constriction, the debris fan is overtopped if the discharge is sufficiently high. As discharge increases above this overtopping discharge, the separation point does not migrate farther upstream. For example, overtopping occurs at the low fan at Eighteen Mile Wash between 28,000 and $44,000 \mathrm{ft}^{3} / \mathrm{s}$ (fig. 6). At most sites, the downstream migration of the reattachment point is controlled by the geometry of the channel. Lengthening of the recirculation zone in the downstream direction is ultimately restricted where another riffle or debris fan farther downstream is encountered by the downstream-migrating reattachment point. An upper limit, therefore, exists on the length of recirculation zones, but the limit is different at different sites.

Sand is stored primarily in main-channel pools and within recirculation zones (Wilson, 1986). Most sand deposits used as campsites are associated with recirculation zones and are formed at discharges typically exceeding $30,000 \mathrm{ft}^{3} / \mathrm{s}$. Sand stored within recirculation zones typically is very well sorted fine to very fine (fig. 7 , curve 7,8 ), whereas sand in channel pools is typically medium in grain size (fig. 7, curve 5, 6).

Channel geometry and hydraulic data based on field mapping of shorelines and currents at various discharges, water-surface slope surveys, and depth-sounder records were collected at 21 detailed study sites (table 3 ). The mean constriction ratio of these sites is 0.49 and is the same as the mean constriction ratio of the debris fans measured by Kieffer (1985) and less than the mean of 70 fans between river miles 0 and 61 discussed above. The 21 sites, therefore, are representative of more narrow constrictions than are associated with most campsites in the Grand Canyon.

Study sites were concentrated in upstream reaches where the effects of dam operations were initially considered to be most significant. Detailed study sites were located in seven reaches (table 4). Study sites in each of these reaches included the dominant types of deposits used for camping (table 2).

\section{History of Flow and Sediment Transport}

Two gaging stations provide long-term information on flow and sediment transport. The gage at Lees Ferry (fig. 1) was established in 1895 , and in 1922, a gage (09402500 Colorado River near Grand Canyon) was established at river mile 87, just above Bright Angel Creek (fig. 1). Suspended-sediment samples were collected at the gage at Lees Ferry during the periods 1929-33,1942-44, and 1947-65 and near Grand Canyon from 


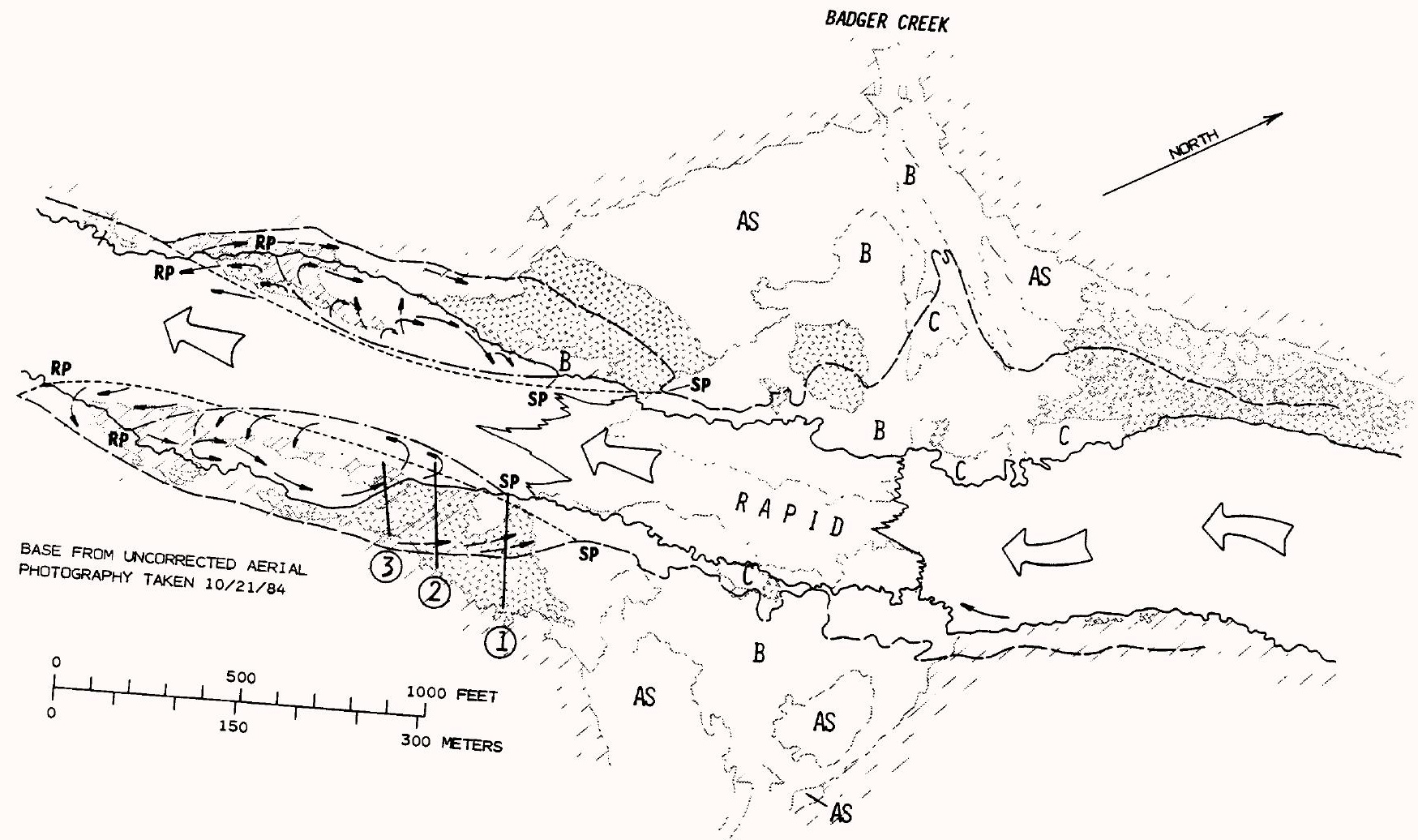

JACKASS CREEK

Figure 5.--Surficial geology and hydraulic features
at Badger Creek Rapid. 

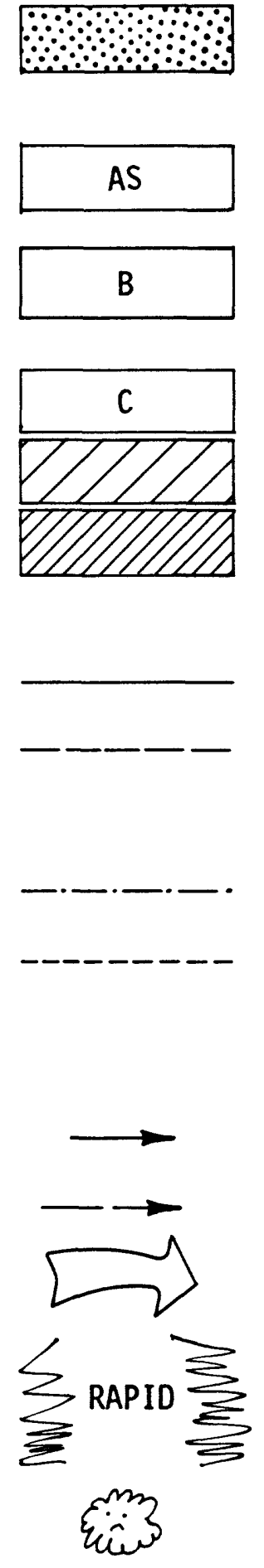

SP

$\mathbf{R P}$

(1) $\checkmark$

RIVER-DEPOSITED OR REWORKED VERY FINE TO MEDIUM SAND (October 21, 1984)

AEOLIAN SAND OR TERRACE DEPOSITS- Silt and fine sand, well sorted

TRIBUTARY DEBRIS FAN-Boulders, cobbles, gravel, sand, poorly sorted; boulders cover more than 50 percent of surface area except in tributary streambed

COBBLES AND GRAVEL

TALUS AND BEDROCK

ADDITIONAL RIVER-DEPOSITED SAND (1973)

EDGE OF WATER

Low flow, October 5, 1985, 5,600 cubic feet per second High flow, May 20, 1985, 44,000 cubic feet per second SEPARATION SURFACE

Low flow

High flow

GENERALIZED SURFACE-FLOW DIRECTION IN RECIRCULATION ZONES

Low flow

High flow

Surface-flow direction of main current

LIMIT OF BREAKING WAVES (WHITE WATER) AT LOW FLOW-At high flow, breaking waves in main current extend downstream to a point opposite center of recirculation zones

DENSE STANDS OF TAMARISK

SEPARATION POINT

REATTACHMENT POINT

LOCATION OF PROFILE LINES, SEE TABLE 13

PHOTOGRAPH SITE-Figure 10

Figure 5. 


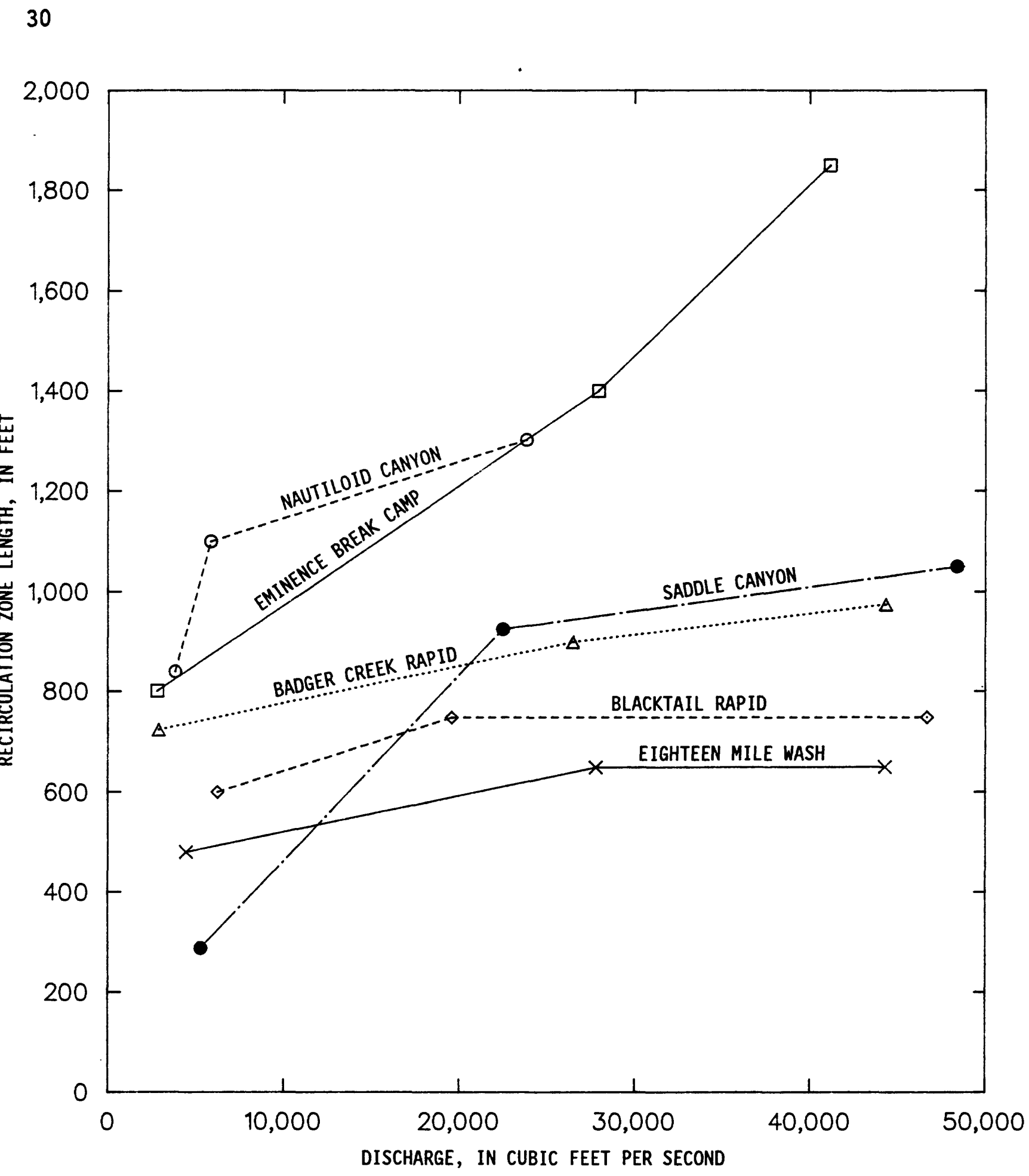

Figure 6.--Change in recirculation-zone length with discharge at six sites. 


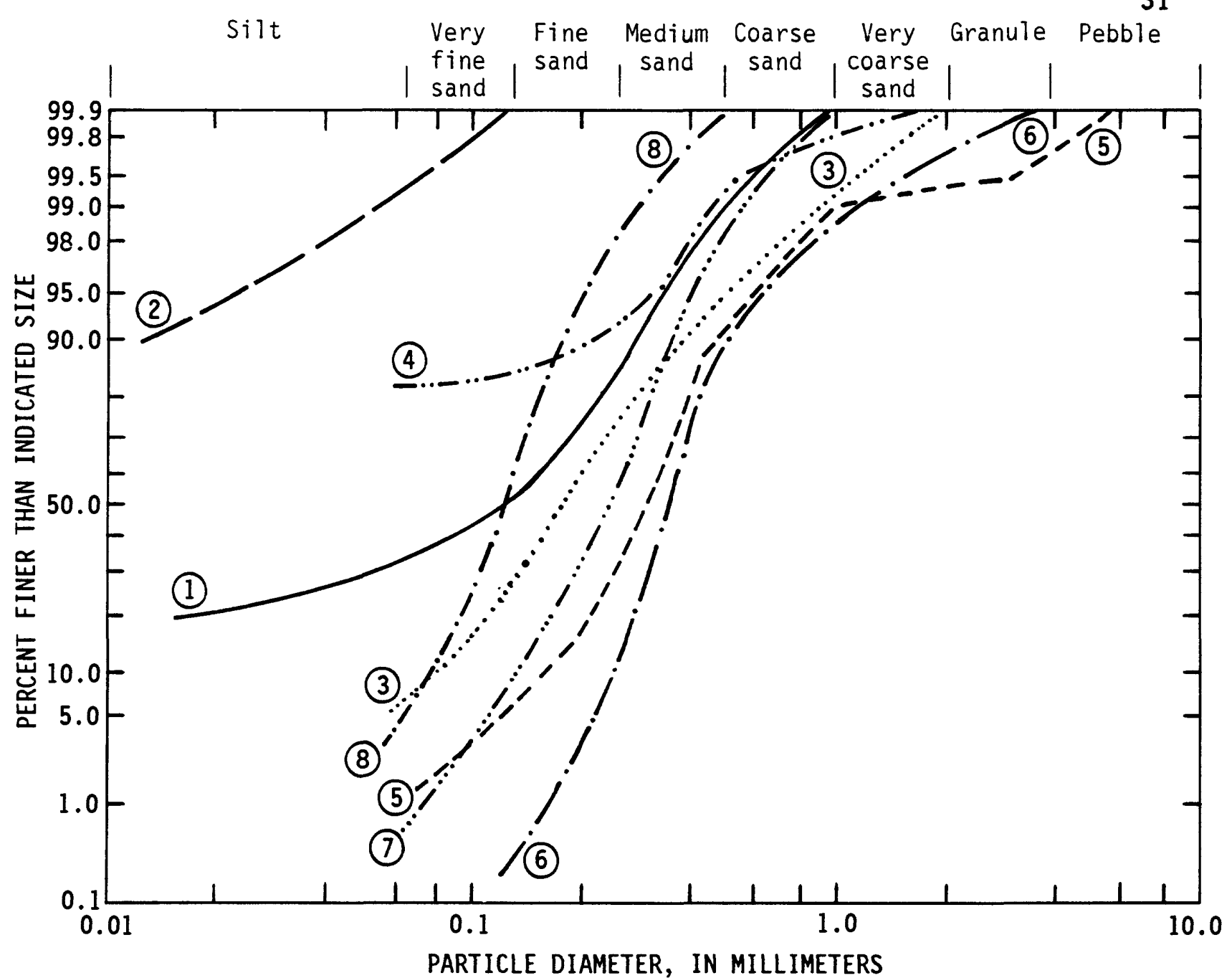

EXPLANATION

\section{Curve Date}

(1) June 13,1957

(2) October 18, 1957

(3) October 22, 1983

(4) October 2, 1983 Post-dam, tributary flow

(5) October 27, 1983 Bed material

(6) December 18, 1985 Bed load

(7) August 13, 19851983 , reattachment deposit,

(8) August 3, 1985 1985, separation deposit,

Figure 7.--Typical particle-size distributions for samples of suspended sediment, bedload, and bed material from the Colorado River near Grand Canyon at river mile 87 and for two alluvial sand deposits. 
Table 3.--Channel geometry and hydraulic characteristics for selected sites [Dashes indicate no data]

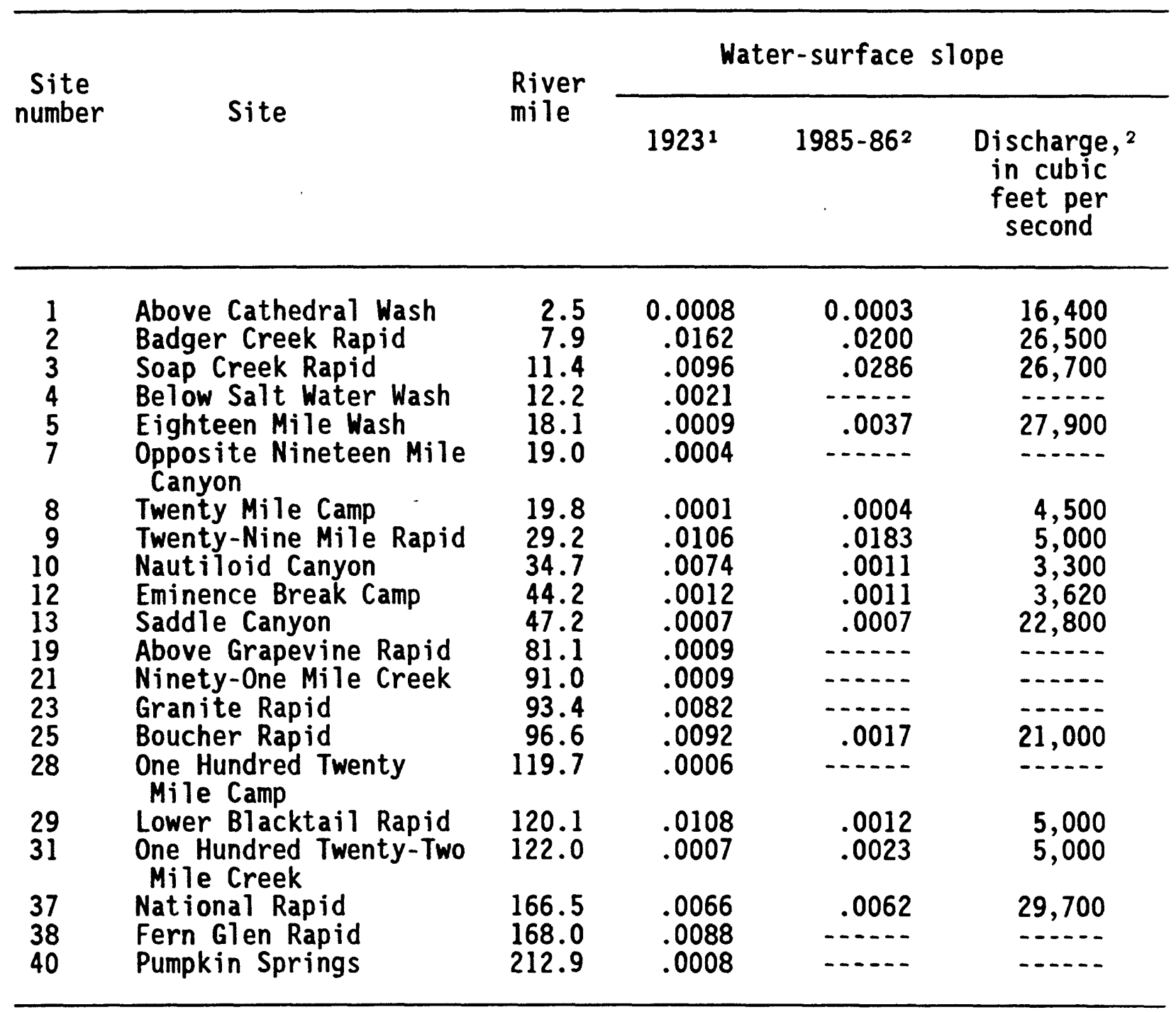

See footnotes at end of table. 
Table 3.--Channel geometry and hydraulic characteristics for selected sites--Cont inued

\begin{tabular}{|c|c|c|c|c|c|}
\hline \multirow{2}{*}{$\begin{array}{c}\text { Site } \\
\text { number }\end{array}$} & \multirow[b]{2}{*}{ Site } & \multirow{2}{*}{$\begin{array}{l}\text { River } \\
\text { mile }\end{array}$} & \multicolumn{3}{|c|}{ Constriction ratio 3} \\
\hline & & & $\begin{array}{l}40,000 \\
\text { cubic } \\
\text { feet } \\
\text { per } \\
\text { second }\end{array}$ & $\begin{array}{l}25,000 \\
\text { cubic } \\
\text { feet } \\
\text { per } \\
\text { second }\end{array}$ & $\begin{array}{l}5,000 \\
\text { cubic } \\
\text { feet } \\
\text { per } \\
\text { second }\end{array}$ \\
\hline $\begin{array}{l}1 \\
2 \\
3 \\
4 \\
5 \\
7\end{array}$ & $\begin{array}{l}\text { Above Cathedral Wash } \\
\text { Badger Creek Rapid } \\
\text { Soap Creek Rapid } \\
\text { Below Salt Water Wash } \\
\text { Eighteen Mile Wash } \\
\text { Opposite Nineteen Mile } \\
\text { Canyon }\end{array}$ & $\begin{array}{r}2.5 \\
7.9 \\
11.4 \\
12.2 \\
18.1 \\
19.0\end{array}$ & $\begin{array}{r}0.58 \\
.65 \\
.71 \\
.55 \\
.93 \\
1.00\end{array}$ & $\begin{array}{r}0.57 \\
.63 \\
.59 \\
.48 \\
.70 \\
.79\end{array}$ & $\begin{array}{r}0.44 \\
.49 \\
.43 \\
.35 \\
.45 \\
.63\end{array}$ \\
\hline $\begin{array}{r}8 \\
9 \\
10 \\
12 \\
13 \\
19 \\
21 \\
23 \\
25 \\
28\end{array}$ & $\begin{array}{l}\text { Twenty Mile Camp } \\
\text { Twenty-Nine Mile Rapid } \\
\text { Nautiloid Canyon } \\
\text { Eminence Break } \\
\text { Saddle Canyon } \\
\text { Above Grapevine Rapid } \\
\text { Ninety-One Mile Creek } \\
\text { Granite Rapid } \\
\text { Boucher Rapid } \\
\text { One Hundred Twenty } \\
\text { Mile Camp }\end{array}$ & $\begin{array}{r}19.8 \\
29.2 \\
34.7 \\
44.2 \\
47.2 \\
81.1 \\
91.0 \\
93.4 \\
96.6 \\
119.7\end{array}$ & $\begin{array}{r}.84 \\
.78 \\
.71 \\
.58 \\
.54 \\
.71 \\
1.00 \\
.78\end{array}$ & $\begin{array}{l}.81 \\
.79 \\
.52 \\
.48 \\
.39 \\
.68 \\
.-- \\
.71 \\
.64 \\
.79\end{array}$ & $\begin{array}{l}.58 \\
.51 \\
.18 \\
.42 \\
.36 \\
.53 \\
.70 \\
.45 \\
.81 \\
.85\end{array}$ \\
\hline $\begin{array}{l}29 \\
31\end{array}$ & $\begin{array}{l}\text { Lower Blacktail Rapid } \\
\text { One Hundred Twenty- } \\
\text { Two Mile Rapid }\end{array}$ & $\begin{array}{l}120.1 \\
122.0\end{array}$ & $\begin{array}{l}.74 \\
.70\end{array}$ & $\begin{array}{l}.58 \\
.55\end{array}$ & $\begin{array}{l}.53 \\
.47\end{array}$ \\
\hline $\begin{array}{l}37 \\
38 \\
40\end{array}$ & $\begin{array}{l}\text { National Rapid } \\
\text { Fern Glen Rapid } \\
\text { Pumpkin Springs }\end{array}$ & $\begin{array}{l}166.5 \\
168 \cdot 0 \\
212.9\end{array}$ & $\begin{array}{r}1.00 \\
.93 \\
.69\end{array}$ & $\begin{array}{l}.70 \\
.66 \\
.52\end{array}$ & $\begin{array}{l}.40 \\
.47 \\
.33\end{array}$ \\
\hline
\end{tabular}

See footnotes at end of table. 
Table 3.--Channel geometry and hydraulic characteristics for selected sites--Continued

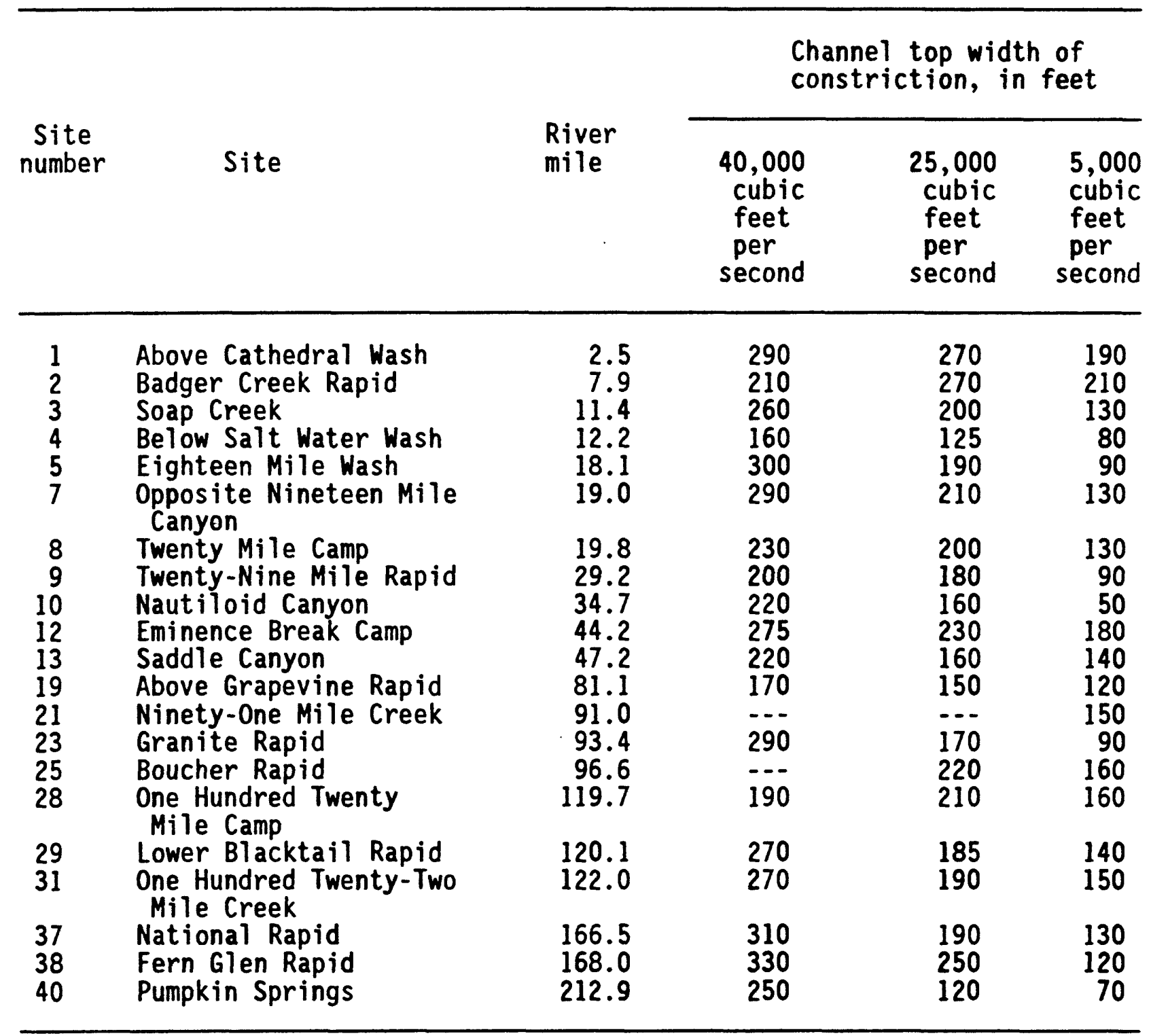

See footnotes at end of table. 
Table 3.--Channel geometry and hydraulic characteristics for selected sites--Continued

\begin{tabular}{|c|c|c|c|c|c|}
\hline \multirow[b]{2}{*}{$\begin{array}{l}\text { Site } \\
\text { number }\end{array}$} & \multirow[b]{2}{*}{ Site } & \multirow[b]{2}{*}{$\begin{array}{l}\text { River } \\
\text { mile }\end{array}$} & \multicolumn{3}{|c|}{ Expansion ratio } \\
\hline & & & $\begin{array}{l}40,000 \\
\text { cubic } \\
\text { feet } \\
\text { per } \\
\text { second }\end{array}$ & $\begin{array}{l}25,000 \\
\text { cubic } \\
\text { feet } \\
\text { per } \\
\text { second }\end{array}$ & $\begin{array}{l}5,000 \\
\text { cubic } \\
\text { feet } \\
\text { per } \\
\text { second }\end{array}$ \\
\hline $\begin{array}{l}1 \\
2 \\
3 \\
4 \\
5 \\
7\end{array}$ & $\begin{array}{l}\text { Above Cathedral Wash } \\
\text { Badger Creek Rapid } \\
\text { Soap Creek Rapid } \\
\text { Below Salt Water Wash } \\
\text { Eighteen Mile Wash } \\
\text { Opposite Nineteen Mile } \\
\text { Canyon }\end{array}$ & $\begin{array}{r}2.5 \\
7.9 \\
11.4 \\
12.2 \\
18.1 \\
19.0\end{array}$ & $\begin{array}{l}1.5 \\
1.8 \\
1.9 \\
2.1 \\
1.4 \\
1.42\end{array}$ & $\begin{array}{l}1.6 \\
1.9 \\
2.1 \\
2.4 \\
2.0 \\
1.80\end{array}$ & $\begin{array}{l}1.8 \\
2.1 \\
2.1 \\
2.9 \\
3.9 \\
2.3\end{array}$ \\
\hline $\begin{array}{r}8 \\
9 \\
10 \\
12 \\
13 \\
19 \\
21 \\
23 \\
25 \\
28\end{array}$ & $\begin{array}{l}\text { Twenty Mile Camp } \\
\text { Twenty-Nine Mile Rapid } \\
\text { Nautiloid Canyon } \\
\text { Eminence Break Camp } \\
\text { Saddle Canyon } \\
\text { Above Grapevine Rapid } \\
\text { Ninety-One Mile Creek } \\
\text { Granite Rapid } \\
\text { Boucher Rapid } \\
\text { One Hundred Twenty } \\
\text { Mile Camo }\end{array}$ & $\begin{array}{r}19.8 \\
29.2 \\
34.7 \\
44.2 \\
47.2 \\
81.1 \\
91.0 \\
93.4 \\
96.6 \\
119.7\end{array}$ & $\begin{array}{l}1.3 \\
1.6 \\
2.0 \\
1.9 \\
2.6 \\
2.0 \\
\cdots-- \\
\cdots-- \\
1.8\end{array}$ & $\begin{array}{l}1.4 \\
1.7 \\
2.8 \\
2.1 \\
3.3 \\
1.7 \\
-1.7 \\
2.7 \\
1.3 \\
1.5\end{array}$ & $\begin{array}{l}1.9 \\
2.7 \\
8.6 \\
2.4 \\
1.9 \\
2.1 \\
1.9 \\
4.9 \\
1.4 \\
1.5\end{array}$ \\
\hline $\begin{array}{l}29 \\
31\end{array}$ & $\begin{array}{l}\text { Lower BTacktail Rapid } \\
\text { One Hundred Twenty-Two } \\
\text { Mile Creek }\end{array}$ & $\begin{array}{l}120.1 \\
122.0\end{array}$ & $\begin{array}{l}2.1 \\
2.3\end{array}$ & $\begin{array}{l}3.0 \\
3.2\end{array}$ & $\begin{array}{l}2.6 \\
2.3\end{array}$ \\
\hline $\begin{array}{l}37 \\
38 \\
40\end{array}$ & $\begin{array}{l}\text { National Rapid } \\
\text { Fern Glen Rapid } \\
\text { Pumpkin Springs }\end{array}$ & $\begin{array}{l}166.5 \\
168.0 \\
212.9\end{array}$ & $\begin{array}{l}1.2 \\
1.6 \\
2.2\end{array}$ & $\begin{array}{l}2.0 \\
2.0 \\
3.8\end{array}$ & $\begin{array}{l}2.7 \\
3.6 \\
6.1\end{array}$ \\
\hline
\end{tabular}

See footnotes at end of table. 
Table 3.--Channel geometry and hydraulic characteristics for selected sites--Continued

\begin{tabular}{|c|c|c|c|c|c|}
\hline \multirow{2}{*}{$\begin{array}{c}\text { Site } \\
\text { number }\end{array}$} & \multirow{2}{*}{ Site } & \multirow{2}{*}{$\begin{array}{l}\text { River } \\
\text { mile }\end{array}$} & \multicolumn{3}{|c|}{$\begin{array}{c}\text { Channel depth, in feet, along } \\
\text { thalweg at discharge of }-28,000 \\
\text { cubic feet per second } 5\end{array}$} \\
\hline & & & $\begin{array}{l}\text { Upstream } \\
\text { from rapid }\end{array}$ & $\begin{array}{c}\text { Constric- } \\
\text { tion }\end{array}$ & $\begin{array}{c}\text { Expan- } \\
\text { sion }\end{array}$ \\
\hline $\begin{array}{l}1 \\
2 \\
3 \\
4 \\
5 \\
7\end{array}$ & $\begin{array}{l}\text { Above Cathedral Wash } \\
\text { Badger Creek Rapid } \\
\text { Soap Creek Rapid } \\
\text { Below Salt Water Wash } \\
\text { Eighteen Mile Wash } \\
\text { Opposite Nineteen Mile } \\
\text { Canyon }\end{array}$ & $\begin{array}{r}2.5 \\
7.9 \\
11.4 \\
12.2 \\
18.1 \\
19.0\end{array}$ & $\begin{array}{l}17 \\
25 \\
32 \\
18 \\
40 \\
33\end{array}$ & $\begin{array}{r}15 \\
8 \\
12 \\
16 \\
22 \\
33\end{array}$ & $\begin{array}{l}40 \\
21 \\
32 \\
50 \\
50 \\
69\end{array}$ \\
\hline $\begin{array}{r}8 \\
9 \\
10 \\
12 \\
13 \\
19 \\
21 \\
23 \\
25 \\
28\end{array}$ & $\begin{array}{l}\text { Twenty Mile Camp } \\
\text { Twenty-Nine Mile Rapid } \\
\text { Nautiloid Canyon } \\
\text { Eminence Break Camp } \\
\text { Saddle Canyon } \\
\text { Above Grapevine Rapid } \\
\text { Ninety-One Mile Creek } \\
\text { Granite Rapid } \\
\text { Boucher Rapid } \\
\text { One Hundred Twenty } \\
\text { Mile Camp }\end{array}$ & $\begin{array}{r}19.8 \\
29.2 \\
34.7 \\
44.2 \\
47.2 \\
81.1 \\
91.0 \\
93.4 \\
96.6 \\
119.7\end{array}$ & $\begin{array}{l}50 \\
31 \\
20 \\
30 \\
18 \\
30 \\
30 \\
32 \\
32 \\
35\end{array}$ & $\begin{array}{l}28 \\
14 \\
16 \\
17 \\
12 \\
12 \\
15 \\
12 \\
11 \\
25\end{array}$ & $\begin{array}{l}50 \\
45 \\
62 \\
44 \\
55 \\
60 \\
49 \\
44 \\
48 \\
27\end{array}$ \\
\hline $\begin{array}{l}29 \\
31\end{array}$ & $\begin{array}{l}\text { Lower Blacktail Rapid } \\
\text { One Hundred Twenty-Two } \\
\text { Mile Creek }\end{array}$ & $\begin{array}{l}120.1 \\
122.0\end{array}$ & $\begin{array}{l}20 \\
40\end{array}$ & $\begin{array}{l}14 \\
12\end{array}$ & $\begin{array}{l}50 \\
46\end{array}$ \\
\hline $\begin{array}{l}37 \\
38 \\
40\end{array}$ & $\begin{array}{l}\text { National Rapid } \\
\text { Fern Glen Rapid } \\
\text { Pumpkin Springs }\end{array}$ & $\begin{array}{l}166.5 \\
168.0 \\
212.9\end{array}$ & $\begin{array}{l}23 \\
20 \\
30\end{array}$ & $\begin{array}{l}12 \\
14 \\
22\end{array}$ & $\begin{array}{l}35 \\
44 \\
85\end{array}$ \\
\hline
\end{tabular}

See footnotes at end of table. 
Table 3.--Channel geometry and hydraulic characteristics for selected sites--Continued

\begin{tabular}{|c|c|c|c|c|c|c|}
\hline \multirow[b]{2}{*}{$\begin{array}{c}\text { Site } \\
\text { number }\end{array}$} & \multirow[b]{2}{*}{ Site } & \multirow[b]{2}{*}{$\begin{array}{c}\text { River } \\
\text { mile }\end{array}$} & \multirow{2}{*}{$\begin{array}{l}\text { Fan } \\
\text { shape } \\
\text { ratio } 6\end{array}$} & \multicolumn{2}{|c|}{ Divergence angle? } & \multirow{2}{*}{$\begin{array}{c}\text { Con- } \\
\text { stric- } \\
\text { tion, } \\
\text { length, } \\
\text { in } \\
\text { feet }\end{array}$} \\
\hline & & & & $\begin{array}{l}40,000 \\
\text { cubic } \\
\text { feet } \\
\text { per } \\
\text { second }\end{array}$ & $\begin{array}{l}5,000 \\
\text { cubic } \\
\text { feet } \\
\text { per } \\
\text { second }\end{array}$ & \\
\hline $\begin{array}{l}1 \\
2 \\
3 \\
4 \\
5 \\
7\end{array}$ & $\begin{array}{l}\text { Above Cathedral Wash } \\
\text { Badger Creek Rapid } \\
\text { Soap Creek Rapid } \\
\text { Below Salt Water Wash } \\
\text { Eighteen Mile Wash } \\
\text { Opposite Nineteen Mile } \\
\text { Canyon }\end{array}$ & $\begin{array}{r}2.5 \\
7.9 \\
11.4 \\
12.2 \\
18.1 \\
19.0\end{array}$ & $\begin{array}{l}4.90 \\
8.70 \\
9.80 \\
4.10 \\
3.80 \\
3.20\end{array}$ & $\begin{array}{r}65 \\
29 \\
12 \\
36 \\
100 \\
-\ldots\end{array}$ & $\begin{array}{r}57 \\
55 \\
7 \\
34 \\
42 \\
24\end{array}$ & $\begin{array}{r}570 \\
800 \\
1,000 \\
400 \\
200 \\
260\end{array}$ \\
\hline $\begin{array}{r}8 \\
9 \\
10 \\
12 \\
13 \\
19 \\
21 \\
23 \\
25 \\
28\end{array}$ & $\begin{array}{l}\text { Twenty Mile Camp } \\
\text { Twenty-Nine Mile Rapid } \\
\text { Nautiloid Canyon } \\
\text { Eminence Break Camp } \\
\text { Saddle Canyon } \\
\text { Above Grapevine Rapid } \\
\text { Ninety-One Mile Creek } \\
\text { Granite Rapid } \\
\text { Boucher Rapid } \\
\text { One Hundred Twenty } \\
\text { Mile Camn }\end{array}$ & $\begin{array}{r}19.8 \\
29.2 \\
34.7 \\
44.2 \\
47.2 \\
81.1 \\
91.0 \\
93.4 \\
96.6 \\
119.7\end{array}$ & $\begin{array}{r}4.90 \\
3.50 \\
2.70 \\
4.00 \\
2.80 \\
5.00 \\
4.13 \\
3.64 \\
7.17 \\
10.00\end{array}$ & $\begin{array}{r}33 \\
29 \\
29 \\
49 \\
78 \\
58 \\
-- \\
1 \\
-- \\
22\end{array}$ & $\begin{array}{r}14 \\
19 \\
27 \\
56 \\
20 \\
25 \\
47 \\
24 \\
15 \\
7\end{array}$ & $\begin{array}{r}140 \\
290 \\
170 \\
500 \\
1,100 \\
120 \\
210 \\
330 \\
380 \\
160\end{array}$ \\
\hline $\begin{array}{l}29 \\
31\end{array}$ & $\begin{array}{l}\text { Lower Blacktail Rapid } \\
\text { One Hundred Twenty-Two } \\
\text { Mile Creek }\end{array}$ & $\begin{array}{l}120.1 \\
122.0\end{array}$ & $\begin{array}{l}3.60 \\
3.68\end{array}$ & $\begin{array}{l}84 \\
90\end{array}$ & $\begin{array}{l}11 \\
30\end{array}$ & $\begin{array}{l}320 \\
420\end{array}$ \\
\hline $\begin{array}{l}37 \\
38 \\
40\end{array}$ & $\begin{array}{l}\text { National Rapid } \\
\text { Fern Glen Rapid } \\
\text { Pumpkin Springs }\end{array}$ & $\begin{array}{l}166.5 \\
168.0 \\
212.9\end{array}$ & $\begin{array}{l}6.40 \\
4.83 \\
4.14\end{array}$ & $\begin{array}{l}13 \\
43 \\
36\end{array}$ & $\begin{array}{r}90 \\
66 \\
5\end{array}$ & $\begin{array}{r}1,100 \\
520 \\
410\end{array}$ \\
\hline
\end{tabular}

'Birdseye (1923).

2 Steepest survey measured in 1985-1986, at indicated discharge.

${ }^{3}$ Average channel width at constriction divided by average channel width upstream.

4Average channel width in expansion divided by average channel width in constriction.

sDepth upstream, in constriction, and in expansion along approximate thalweg at $-28,000$ cubic feet per second (Wilson, 1986).

'Distance along debris fan parallel to channel at low flow divided by distance perpendicular to channel.

${ }^{7}$ Angle between main-channel flow and channel banks in degrees at expansion for two discharges. 
Table 4.--Detailed study sites in relation to reaches

Types of deposits

\begin{tabular}{|c|c|c|c|}
\hline Reach segment & Separation & Reattachment & Channel-margin \\
\hline Permian Section & Badger Creek Rapid & & \\
\hline Supai Gorge & $\begin{array}{l}\text { Soap Creek Rapid } \\
\text { Below Salt Water } \\
\text { Wash } \\
\text { Ejghteen Mile } \\
\text { Wash } \\
\text { Twenty Mile Camp }\end{array}$ & $\begin{array}{l}\text { Opposite } \\
\text { Nineteen } \\
\text { Mile } \\
\text { Canyon }\end{array}$ & \\
\hline Redwall Gorge & $\begin{array}{l}\text { Twenty-nine Mile } \\
\text { Rapid } \\
\text { Nautiloid Canyon }\end{array}$ & $\begin{array}{l}\text { Nautiloid } \\
\text { Canyon }\end{array}$ & \\
\hline $\begin{array}{l}\text { Lower Marble } \\
\text { Canyon }\end{array}$ & $\begin{array}{l}\text { Eminence Break } \\
\text { Camp }\end{array}$ & $\begin{array}{l}\text { Eminence } \\
\text { Break } \\
\text { Camp } \\
\text { Saddle } \\
\text { Canyon }\end{array}$ & \\
\hline $\begin{array}{l}\text { Upper Granite } \\
\text { Gorge }\end{array}$ & $\begin{array}{l}\text { Ninety-One } \\
\text { Mile Creek } \\
\text { Granite Rapid } \\
\text { Boucher Rapid }\end{array}$ & & $\begin{array}{l}\text { Above Grapevine } \\
\text { Rapid }\end{array}$ \\
\hline Aisles & & $\begin{array}{l}\text { Lower Blacktail } \\
\text { Blacktail } \\
\text { Rapid } \\
\text { One Hundred } \\
\text { Twenty-Two } \\
\text { Mile Creek }\end{array}$ & $\begin{array}{l}\text { One Hundred } \\
\text { Twenty Mile } \\
\text { Camp }\end{array}$ \\
\hline Lower Canyon & $\begin{array}{l}\text { National Rapid } \\
\text { Fern Glen Rapid }\end{array}$ & National Rapid & $\begin{array}{l}\text { Pumpkin } \\
\text { Springs }\end{array}$ \\
\hline
\end{tabular}

1925-72. Sediment data also were collected at these two gages from June to December 1983 and from October 1985 through January 1986. Three additional gages were operated during the latter two periods. These short-term gages were: at river mile 61, just above the confluence with the Little Colorado River $(09383100$ Colorado River above the Little Colorado River, near Desert View); at river mile 166, just above National Rapid (09404120 Colorado River above National Canyon, near Supai); and at river mile 225, just above Diamond Creek Rapid (fig. 1).

Before closure of Glen Canyon Dam in March 1963, discharge at Lees Ferry typically reached its annual peak in June in response to 
snowmelt runoff from the upper basin. Smaller peaks occurred during the late summer and fall in response to rain in tributary watersheds downstream from Lees Ferry (fig. 8). Suspended-sediment concentrations tended to be highest during these periods of tributary flow, and suspended sediment was dominated by silt and clay-sized material (fig. 7, curve 2).

Daily mean discharge of water for 1982 (fig. 9) was typical of the period 1965-82. During that period, short-term discharge fluctuations dominated, and discharge exceeded powerplant capacity of $31,500 \mathrm{ft}^{3} / \mathrm{s}$ only in April, May, and June 1965 and for a very short period in late June and early July 1980. Maximum instantaneous discharge at Lees Ferry was $60,200 \mathrm{ft}^{3} / \mathrm{s}$ in 1965 and $44,800 \mathrm{ft}^{3} / \mathrm{s}$ in 1980 . Annual suspended-sediment load past Lees Ferry decreased from $76.3 \times 10^{6}$ tons/yr in the period just before construction of the dam (1948 to 1958) to $8.6 \times 10^{6}$ tons/yr just after dam completion (1963 to 1965) (Laursen and others, 1976), which is a decrease of almost 90 percent. For the same periods, volume of water passing Lees Ferry decreased about 55 percent (Anderson and White, 1979).

The present study was planned and initiated in 1982 and early 1983 when flows such as those illustrated in figure 2 had prevailed for nearly 20 years. An exceptional combination of weather conditions and management decisions during the winter of 1982-83, however, caused subsequent flows to deviate from the previous regime (fig. 9). A record post-dam high instantaneous discharge of $97,300 \mathrm{ft}^{3} / \mathrm{s}$ passed Lees Ferry on June 29, 1983. From June 1983 until 0ctober 1, 1985, discharges were higher and steadier than ever experienced since closure of the dam. Discharges of as much as $46,000 \mathrm{ft}^{3} / \mathrm{s}$ can be released without using the spillways; $31,500 \mathrm{ft}^{3} / \mathrm{s}$ can be released through the powerplant and $14,500 \mathrm{ft} / \mathrm{s}$ through river outlet works (David Wegner, U.S. Bureau of Reclamation, oral commun., 1986). The flat-topped hydrographs of the summers of 1984 and 1985 (fig. 9) resulted from maximum releases through the river outlet works and powerplant. Discharges in June 1983 exceeded powerplant and outlet work capacity, and spillways were used. Only during a special fluctuating-flow study period-0ctober 1 , 1985, to January 15, 1986-did releases resemble those characteristic of the 1965-82 period. The special fluctuating-flow study was planned and carried out for the purpose of providing a period in which to investigate the response of the river to typical powerplant releases.

\section{CHARACTERISTICS AND CLASSIFICATION OF ALLUVIAL SAND DEPOSITS}

Fine-grained sediments are stored in channel pools, in recirculation zones, and in deposits that continuously line the wider sections of the river. Except for the widest reaches, most alluvial deposits are associated with the recirculation zones caused by minor bedrock or talus abutments or by large debris fans. In parts of the widest reaches of the Grand Canyon, terracelike deposits exist. Deposits associated with large recirculation zones are the most numerous and extensive of all alluvial sand deposits in Grand Canyon National Park.

Side-scan sonar surveys, recording depth-sounder surveys (Wilson, $1986)$ and photography taken at low river stage demonstrate that the average bed elevation of recirculation zones is much higher than that of 


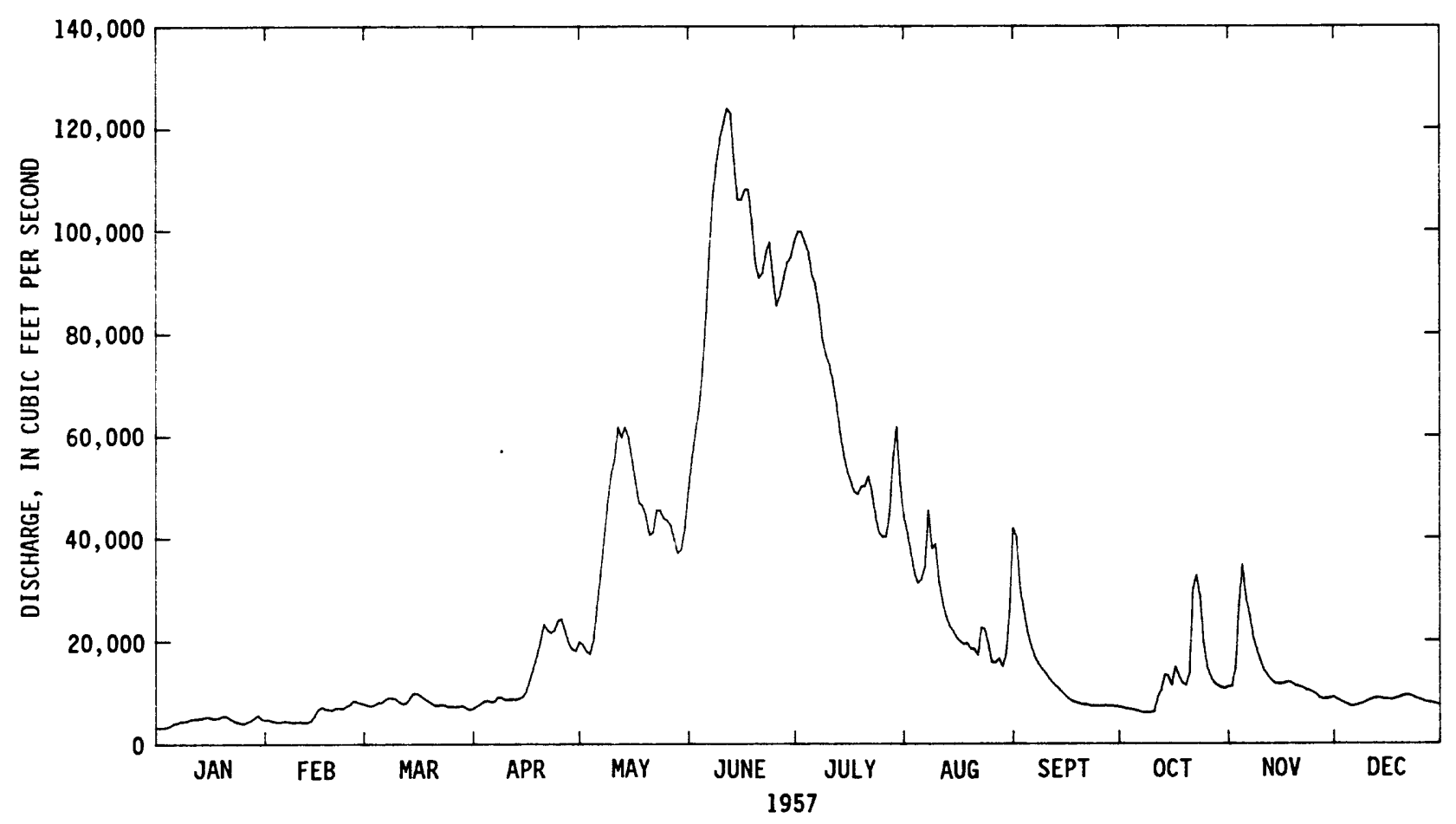

Figure 8.--Daily mean discharge of the Colorado River at Lees Ferry, 1957. 


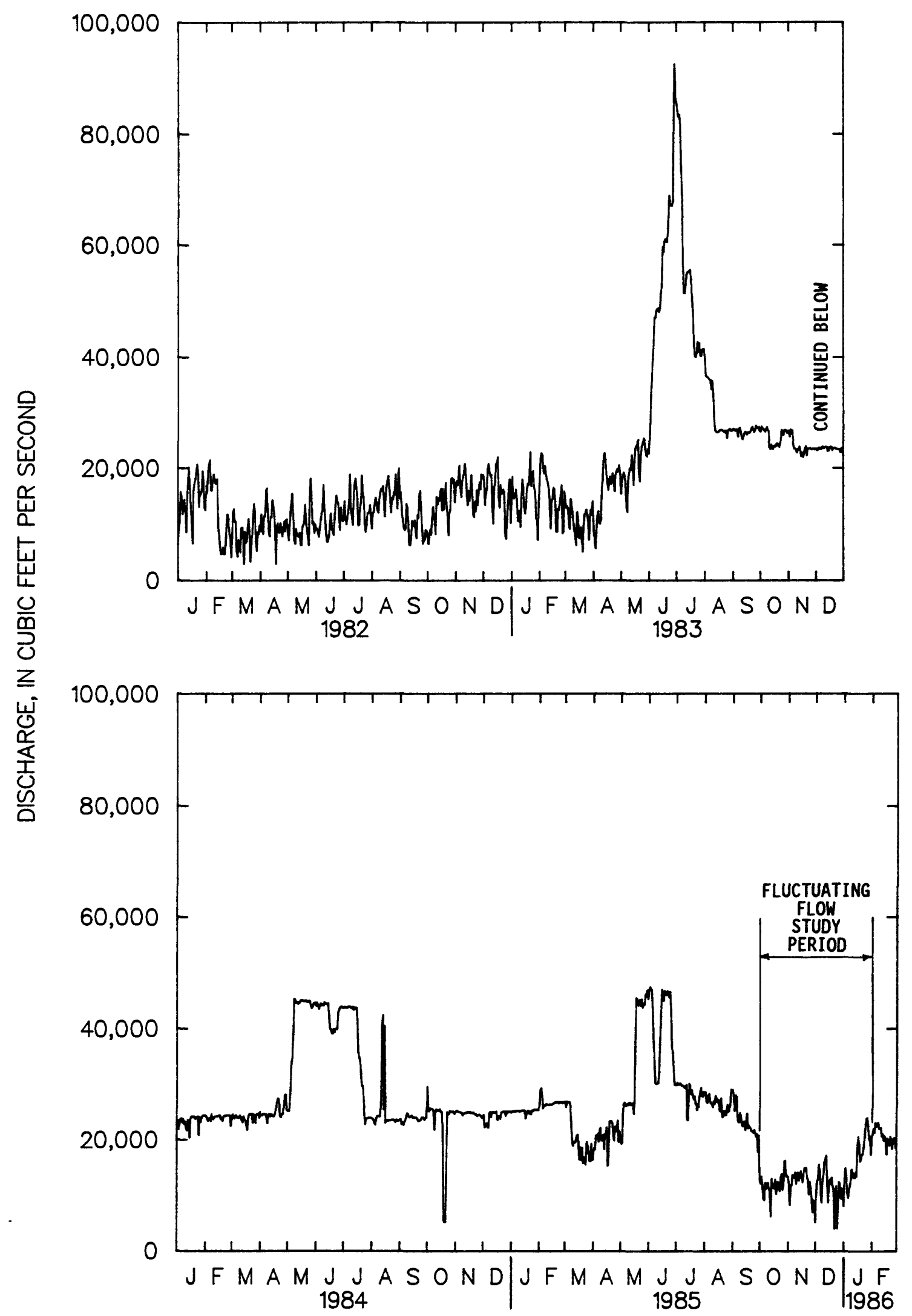

Figure 9.--Daily mean discharge of the Colorado River at Lees Ferry, 1982 to February 1986. 
the adjacent channel. A pool or scour hole occurs immediately downstream from the constriction. Adjacent to and downstream from this scour hole, the channel rises to the higher surface of a sandy alluvial deposit (fig. 3B). The upper surface of the sandy deposit typically has relief of 10 to $50 \mathrm{ft}$. The difference between the average bed elevation within a recirculation zone and the elevation of the adjacent thalweg varies from site to site. For example, at Blacktail Rapid the elevation difference exceeds $80 \mathrm{ft}$, and at National Rapid and Eminence Break Camp, the elevation difference exceeds $40 \mathrm{ft}$.

The separation and reattachment deposits associated with recirculation zones are composed primarily of medium to very fine sand. Between Lees Ferry and Bright Angel Creek, 22 deposits created since 1983 were sampled (table 5). Of the 55 samples taken at these deposits, only 4 contained less than 90 percent sand, and none of these samples contained more than 1 percent very coarse sand greater than $1 \mathrm{~mm}$.

All samples of deposits between Lees Ferry and Bright Angel Creek inundated in 1983 or more recently have graphic means (Folk, 1968) between 0.095 and $0.39 \mathrm{~mm}$. Of the 33 samples of deposits created by the discharges of 1983, 25 are fine sand and most are moderately well sorted. Fewer samples were collected of sediments deposited in 1984 and 1985, and half of these samples are medium sand between 0.25-0.50 mm.

\section{Separation Deposits}

Separation deposits mantle and typically extend downstream from a debris fan. A zone of interspersed sand and boulders separates the separation deposit from the debris-flow deposits located upstream (fig. 10). The separation deposit generally forms one continuous gradual slope from crest to water's edge, but discrete terrace-like levels may exist.

The most upstream part of most of these deposits commonly does not border the low-flow river channel; boulders are found between the sand deposit and the water's edge (fig. 5). Downstream migration of separation points with decreasing discharge probably causes erosion of sand in the upstream low-elevation portion of the separation deposit resulting in this depositional pattern.

Separation deposits form in low-velocity areas and in secondary eddies upstream from the primary-eddy return-current channel. At some sites, a bar forms in a secondary eddy and the upstream-facing slipface of this deposit migrates upstream and eventually becomes attached to the debris fan. The process of separation deposit formation was observed at Eighteen Mile Wash where a separation deposits (fig. 11) formed in a secondary eddy at a discharge of $45,000 \mathrm{ft}^{3} / \mathrm{s}$. At this discharge, the downstream part of the Eighteen Mile Wash debris fan was inundated. Velocity of this secondary eddy was much less than the main channel. Surface velocity through the riffle, at a discharge of $45,000 \mathrm{ft}^{3} / \mathrm{s}$ on May 22, 1985, was measured to be about $16 \mathrm{ft} / \mathrm{s}$ on the basis of timing drifting boats. Mean velocities over the deposit in the low-velocity area at the same time did not exceed $1.5 \mathrm{ft} / \mathrm{s}$ (fig.12B). Discharge over the 
Table 5. - - Particle-size characteristics of allivial sand deposits between Lees Ferry at river mile 0 and Bright Angel Creek at river mile 87.5

[mm, millimeter; $\phi,-\log _{2}$ (millimeter)]

\begin{tabular}{|c|c|c|c|c|c|c|}
\hline $\begin{array}{l}\text { River } \\
\text { mile }\end{array}$ & $\begin{array}{l}\text { Sample } \\
\text { number }\end{array}$ & $\begin{array}{l}\text { Time } \\
\text { of } \\
\text { depo- } \\
\text { sition }\end{array}$ & $\begin{array}{l}\text { Deposit } \\
\text { type }\end{array}$ & $\begin{array}{l}\text { Graphic } \\
\text { mean } \\
\text { size } \\
\text { (mon) }\end{array}$ & $\begin{array}{c}\text { Graphic } \\
\text { standard } \\
\text { doviation } \\
(\phi)\end{array}$ & Description 1 \\
\hline 0.0 & JCS-03 & Pre-dam & Channel margin & 0.041 & 1.7 & Poorly sorted silt \\
\hline 0.0 & JCS-01 & 1983 & Channel margin & .14 & .6 & $\begin{array}{l}\text { Woderately well-sorted } \\
\text { Eine sand }\end{array}$ \\
\hline 0.0 & JCS-02 & 1983 & Channel margin & .14 & .6 & $\begin{array}{l}\text { Moderately well-sorted } \\
\text { fine sand }\end{array}$ \\
\hline 2.0 & JBG-06 & Pre-dam & Channel margin & .072 & .8 & $\begin{array}{l}\text { Moderately sorted } \\
\text { very fine sand }\end{array}$ \\
\hline 2.0 & JBG-07 & Pre-dam & Channel margin & .041 & .9 & Moderately sorted silt \\
\hline 5.7 & JBG-08 & 1983 & Separation & .23 & .6 & $\begin{array}{l}\text { Moderately well-sorted } \\
\text { fine sand }\end{array}$ \\
\hline 11.4 & JBG-09 & Pre-dam & Separation & .14 & .6 & $\begin{array}{l}\text { Moderately well-sorted } \\
\text { fine sand }\end{array}$ \\
\hline 11.4 & JBG-10 & Pre-dam & Separation & .16 & .7 & $\begin{array}{l}\text { Moderately well-sorted } \\
\text { fine sand }\end{array}$ \\
\hline 18.1 & JCS $-85-01$ & 1985 & Separation & .12 & .5 & $\begin{array}{l}\text { Moderately well-sorted } \\
\text { very fine sand }\end{array}$ \\
\hline 18.1 & JCS-85-02 & 1985 & Separation & .17 & .8 & $\begin{array}{l}\text { Moderately sorted } \\
\text { fine sand }\end{array}$ \\
\hline 19.0 & JCS-04 & 1984 & Reattachment & .39 & .4 & Well-sorted medium sand \\
\hline 31.5 & JBG-13 & 1983 & Separation & .27 & .45 & Well-sorted medium sand \\
\hline 32.0 & JBG-15 & 1983 & Channel margin & .23 & .6 & $\begin{array}{l}\text { Moderately well-sorted } \\
\text { fine sand }\end{array}$ \\
\hline 47.2 & JCS-13 & Pre-dam & Separation & .12 & .58 & $\begin{array}{l}\text { Moderately well-sorted } \\
\text { very fine sand }\end{array}$ \\
\hline 47.2 & JCS-14 & 1983 & Separation & .13 & .5 & Well-sorted fine sand \\
\hline 47.2 & JCS- 15 & 1984 & Separation & .10 & .5 & $\begin{array}{l}\text { Well-sorted very fine } \\
\text { sand }\end{array}$ \\
\hline 47.3 & JBG-16 & Pre-dam & Reattachment & .074 & .85 & $\begin{array}{l}\text { Moderately sorted } \\
\text { very fine sand }\end{array}$ \\
\hline 47.3 & JBG-17 & 1983 & Reattachment & .28 & .4 & Well-sorted medium sand \\
\hline 47.3 & JBG-18 & 1983 & Reattachment & .23 & .48 & Well-sorted fine sand \\
\hline 47.3 & JCS-05 & 1984 & Reattachment & .15 & .6 & $\begin{array}{l}\text { Moderately well-sorted } \\
\text { fine sund }\end{array}$ \\
\hline 47.3 & JCS-06 & 1984 & Reattachment & .29 & .4 & Well-sorted medium sand \\
\hline 47.3 & JCS-07 & 1984 & Reattachment & .27 & .4 & Well-sorted medium sand \\
\hline 47.3 & JCS-08 & 1984 & Reattachment & .27 & .4 & Well-sorted medium sand \\
\hline 47.3 & JCS-09 & 1984 & Reattachment & .29 & .36 & Well-sorted medium sand \\
\hline 47.3 & JCS-10 & 1983 & Reattachment & .19 & .89 & $\begin{array}{l}\text { Moderately sorted } \\
\text { fine sand }\end{array}$ \\
\hline 47.3 & JCS-11 & 1983 & Reattachment & .15 & .5 & Well-sorted fine sand \\
\hline 47.3 & JCS-12 & Pre-dam & Reattachment & .13 & .48 & $\begin{array}{l}\text { Well-sorted fine sand } \\
\text { and very fine sand }\end{array}$ \\
\hline 52.3 & JBG-21 & 1983 & Channel margin & 0.22 & 0.44 & Well-sorted fine sand \\
\hline 53.0 & $J C S-16$ & 1984 & Channel bar & .33 & .47 & Woll-sorted medium sand \\
\hline 53.2 & JCS-17 & 1984 & Chamnel margin & .17 & .50 & Well-sorted fine sand \\
\hline 56.0 & JBG-23 & 1983 & Separation & .20 & .27 & $\begin{array}{l}\text { Very well-sorted } \\
\text { fine sand }\end{array}$ \\
\hline 56.0 & JBG-24 & 1983 & Separation & .20 & .5 & Well-sorted fine sand \\
\hline 56.3 & JCS $-85-03$ & 1985 & $\begin{array}{l}\text { Recirculation } \\
\text { zone bedload }\end{array}$ & .29 & .47 & Well-sorted medium sand \\
\hline 56.3 & JCS-85-04 & 1985 & $\begin{array}{l}\text { Recirculation } \\
\text { zone bedload }\end{array}$ & .29 & .41 & Well-sorted medium sand \\
\hline 56.3 & JCS $-85-05$ & 1985 & $\begin{array}{l}\text { Recirculation } \\
\text { zone bedload }\end{array}$ & .29 & .45 & Well-sorted medium sand \\
\hline
\end{tabular}


Table 5. - Particle-size characterlstics of alluvial sand deposits between Lees Ferry at river mile 0 and Brisht Angel Creek at Fiver mile 87,5 --Continued

\begin{tabular}{|c|c|c|c|c|c|c|}
\hline $\begin{array}{l}\text { River } \\
\text { mile }\end{array}$ & $\begin{array}{l}\text { Semple } \\
\text { number }\end{array}$ & $\begin{array}{l}\text { Time } \\
\text { of } \\
\text { depo- } \\
\text { sition }\end{array}$ & $\begin{array}{l}\text { Deposit } \\
\text { type }\end{array}$ & $\begin{array}{l}\text { Graphic } \\
\text { mean } \\
\text { size } \\
\text { (mo) }\end{array}$ & $\begin{array}{l}\text { Graphic } \\
\text { standard } \\
\text { deviation } \\
\text { (ф) }\end{array}$ & Description 1 \\
\hline 56.3 & $J C S-85-10$ & 1885 & $\begin{array}{l}\text { Recirculation } \\
\text { zone bedload }\end{array}$ & .27 & .43 & Well-sorted medium sand \\
\hline 56.3 & $J C S-85-11$ & 1985 & $\begin{array}{l}\text { Recirculation } \\
\text { zone bedload }\end{array}$ & .27 & .38 & Well-sorted medium sand \\
\hline 60.6 & JCS-85-12 & 1885 & $\begin{array}{l}\text { Recirculation } \\
\text { zone bedload }\end{array}$ & .33 & .38 & Well-sorted medium sand \\
\hline 60.6 & $J C S-85-13$ & 1985 & $\begin{array}{l}\text { Recirculetion } \\
\text { zone bedload }\end{array}$ & .33 & .38 & Well-sorted medium sand \\
\hline 60.6 & JCS-85-14 & 1885 & $\begin{array}{l}\text { Recirculation } \\
\text { zone bedload }\end{array}$ & .32 & .4 & Well-sorted medium sand \\
\hline 61.1 & JCS-18 & 1883 & Channel margin & .15 & .52 & $\begin{array}{l}\text { Moderately well-sorted } \\
\text { fine sand }\end{array}$ \\
\hline 61.1 & JCS-19 & 1883 & Channel margin & .20 & .51 & $\begin{array}{l}\text { Moderately well-sorted } \\
\text { fine sand }\end{array}$ \\
\hline 61.1 & JCS -20 & 1883 & Channel mergin & .18 & .55 & $\begin{array}{l}\text { Moderately well-sorted } \\
\text { fine sand }\end{array}$ \\
\hline 61.1 & JBG-25 & 1883 & Channel margin & .18 & .50 & Well-sorted fine sand \\
\hline 61.7 & JCS-21 & 1984 & Separation & .19 & .57 & $\begin{array}{l}\text { Moderately well=sorted } \\
\text { fine sand }\end{array}$ \\
\hline $\begin{array}{l}61.7 \\
62.5\end{array}$ & $\begin{array}{l}\text { JCS }-22 \\
\text { JBG-26 }\end{array}$ & $\begin{array}{l}1883 \\
1983\end{array}$ & $\begin{array}{l}\text { Separation } \\
\text { Channel margin }\end{array}$ & $\begin{array}{l}.15 \\
.27\end{array}$ & $\begin{array}{l}.49 \\
.42\end{array}$ & $\begin{array}{l}\text { Well-sorted fine sand } \\
\text { Well-sorted fine sand }\end{array}$ \\
\hline 65.5 & JBG-29 & 1983 & Channel margin & .10 & .8 & $\begin{array}{l}\text { Moderately sorted } \\
\text { very fine send }\end{array}$ \\
\hline 71.3 & JBG-31 & 1983 & Channel margin & .15 & .5 & Well-sorted fine sand \\
\hline 71.3 & JBG-32 & Pre-dam & Channel margin & .035 & 1.5 & Poorly sorted silt. \\
\hline 71.3 & JBG-34 & 1983 & Channel mergin & .095 & .6 & $\begin{array}{l}\text { Moderately well-sorted } \\
\text { very fine sand }\end{array}$ \\
\hline 71.3 & JBG-35 & 1883 & Channel margin & .13 & .47 & $\begin{array}{l}\text { Well-sorted very fine } \\
\text { sand }\end{array}$ \\
\hline 71.3 & JBG-36 & Pre-dam & Channel margin & 0.095 & 0.5 & $\begin{array}{l}\text { Well-sorted very Iine } \\
\text { sand }\end{array}$ \\
\hline 71.3 & JCS-23 & 1883 & Channel margin & .14 & .5 & Well-sorted Ifne sand \\
\hline 71.3 & JCS-24 & Pre-dam & Channel marg in & .10 & .58 & $\begin{array}{l}\text { Moderately well-sorted } \\
\text { very IIne sand }\end{array}$ \\
\hline 71.3 & JCS-25 & Pre-dam & Channel margin & .09 & .58 & $\begin{array}{l}\text { Moderately well-sorted } \\
\text { very fine sand }\end{array}$ \\
\hline 71.3 & JCS-26 & 1983 & Channel margin & .13 & .45 & Well-sorted fine sand \\
\hline 71.3 & JCS-27 & 1983 & Channel margin & .18 & .5 & Well-sorted fine sand \\
\hline 71.3 & $\mathrm{JCS}-28$ & 1983 & Channel margin & .17 & .4 & Well-sorted fine sand \\
\hline 72.9 & JBG-37 & 1983 & Channel margin & .15 & .5 & Well-sorted fine sand \\
\hline 75.6 & JBG-38 & 1983 & Separation & .12 & .5 & $\begin{array}{l}\text { Well-sorted very fine } \\
\text { sand }\end{array}$ \\
\hline 75.6 & JBG-39 & 1883 & Separation & .10 & .6 & $\begin{array}{l}\text { Hoderately well-sorted } \\
\text { very flne sand }\end{array}$ \\
\hline 81.1 & $J C S-29$ & 1983 & Channel margin & .28 & .5 & $\begin{array}{l}\text { Hoderately well-sorted } \\
\text { medium sand }\end{array}$ \\
\hline 81.1 & JCS-30 & 1983 & Channel margin & .13 & .6 & $\begin{array}{l}\text { Hoderately well-sorted } \\
\text { fine sand }\end{array}$ \\
\hline 81.1 & JBG -40 & 1983 & Channel mergin & .23 & .8 & $\begin{array}{l}\text { Moderately well-sorted } \\
\text { fine sand }\end{array}$ \\
\hline 81.1 & JBG-41 & 1883 & Channel margin & .15 & .6 & $\begin{array}{l}\text { Moderately well-sorted } \\
\text { fine sand }\end{array}$ \\
\hline 81.1 & JBG-42 & 1983 & Channel margin & .13 & .6 & $\begin{array}{l}\text { Moderately well-sorted } \\
\text { fine sand }\end{array}$ \\
\hline
\end{tabular}

${ }^{1}$ Besed on Wentworth size clesses and sorting classification (Folk, 1968, p.46). 


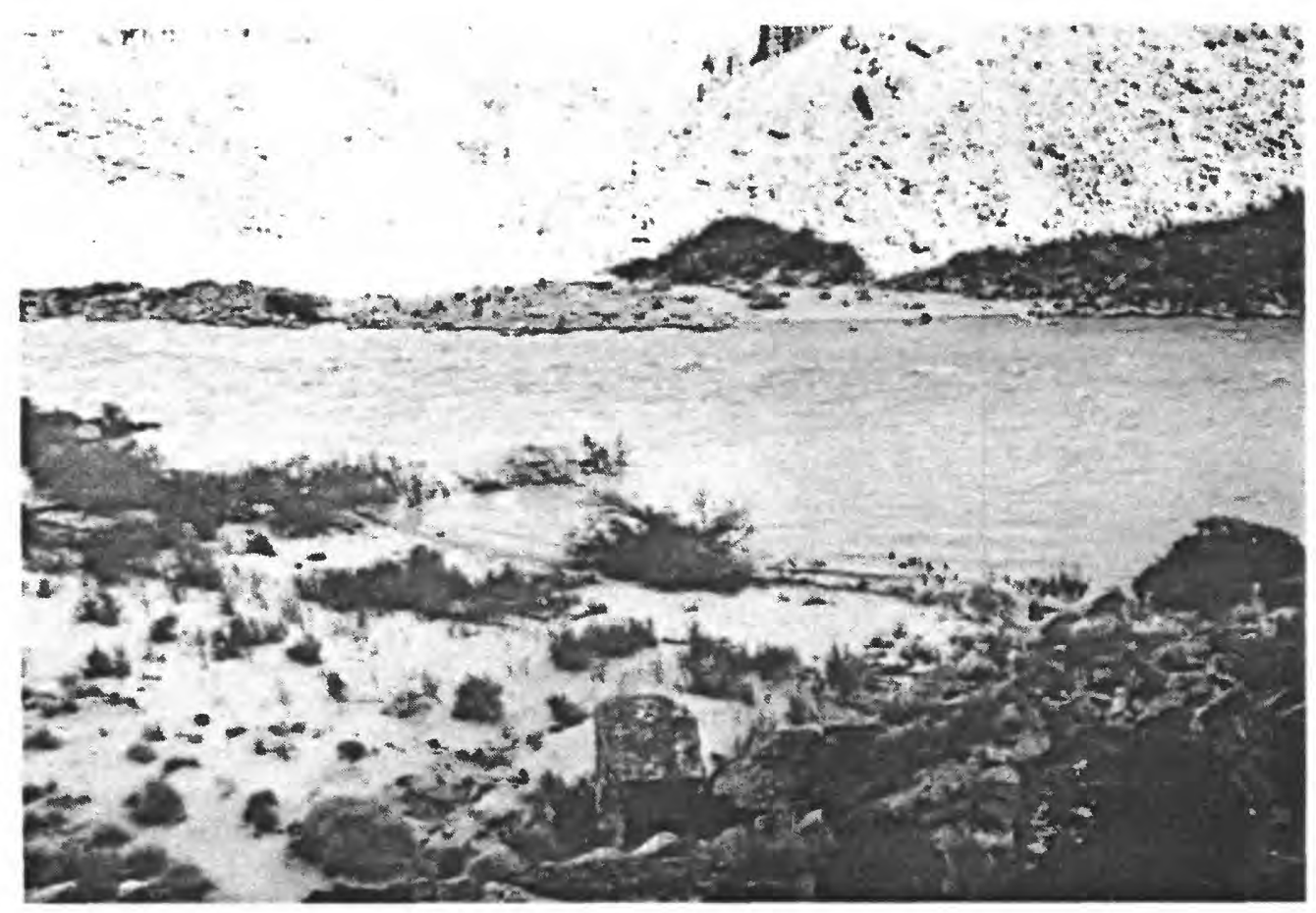

Figure 10.--Separation deposits downstream from Badger Creek Rapid, July 30 , 1985. Separation deposits mantle Badger Creek debris fan in foreground and Jackass Creek debris fan on opposite bank. Photograph site located in figure 5. 

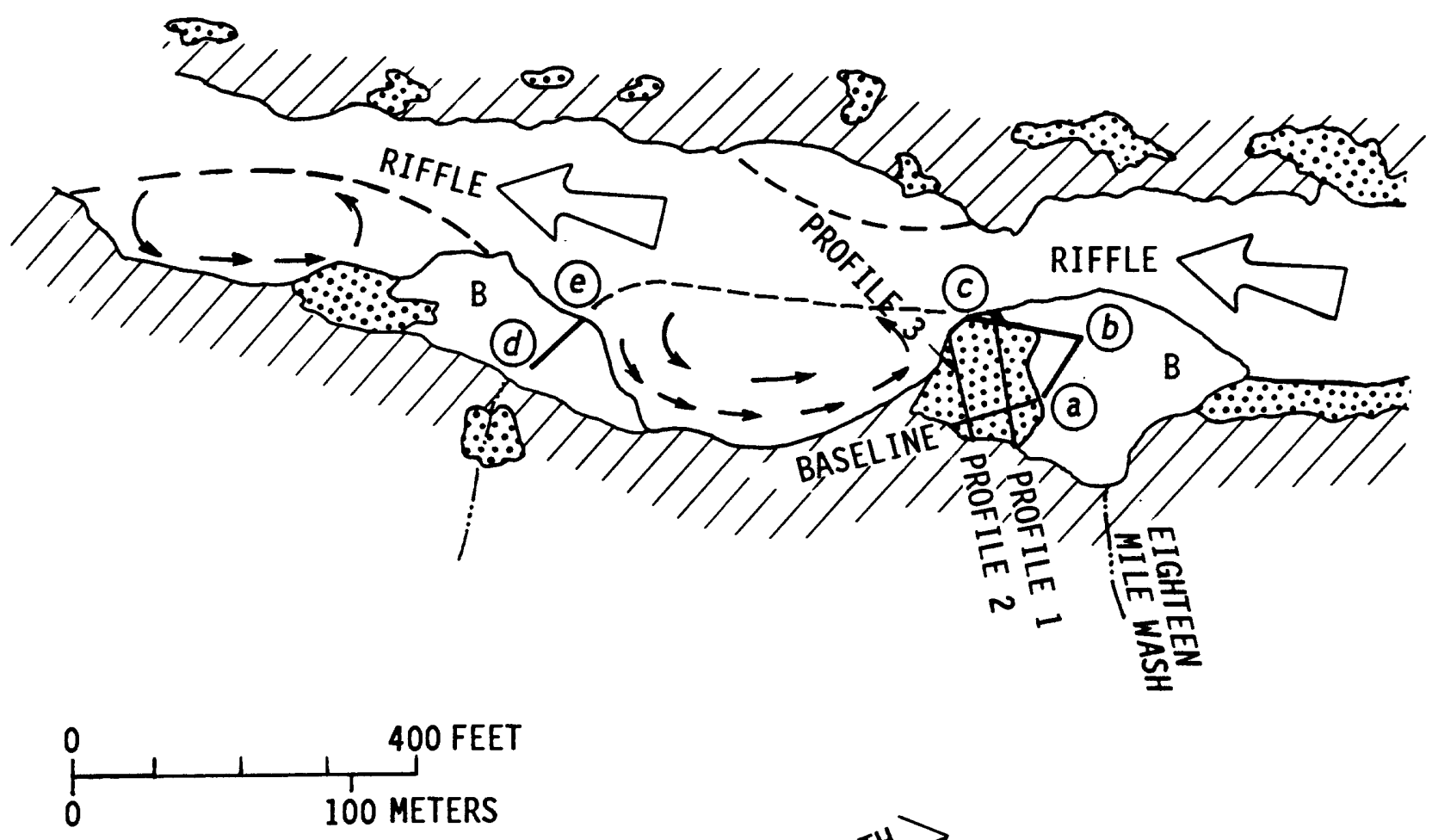

Figure 11.--Surficial geology and hydraulic features near Eighteen Mile Wash. 


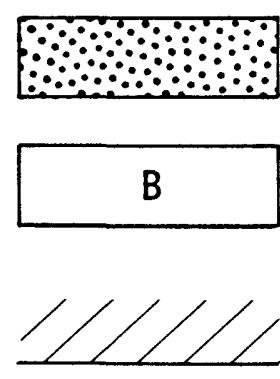

(a)

(b)

(c)

(d)

(e)
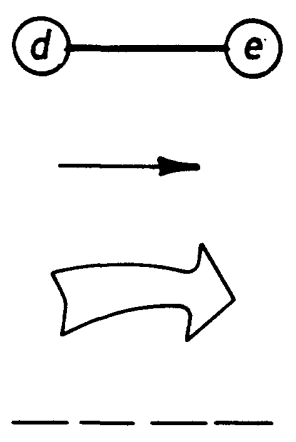

PROFILE 1

RIVER-DEPOSITED OR REWORKED VERY FINE TO MEDIUM SAND (October 21, 1984)

TRIBUTARY DEBRIS FAN-Boulders, cobbles, gravel, sand, poorly sorted; boulders cover more than 50 percent of surface area except in tributary streambed

TALUS AND BEDROCK

LOCATION OF SEPARATION POINT, 45,000 CUBIC FEET PER SECOND, MAY 22, 1985

LOCATION OF SEPARATION POINT, 28,000 CUBIC FEET PER SECOND, AUGUST 2, 1985

LOCATION OF SEPARATION POINT, 4,200 CUBIC FEET PER SECOND, OCTOBER 9, 1985

LOCATION OF REATTACHMENT POINT, 28,000 CUBIC FEET PER SECOND, AUGUST 2, 1985

LOCATION OF REATTACHMENT POINT, 4,200 CUBIC FEET PER SECOND, OCTOBER 9, 1985

PATH OF MOVEMENT OF SEPARATION OR REATTACHMENT POINTS

GENERALIZED SURFACE-FLOW DIRECTION IN RECIRCULATION ZONES, 4,200 CUBIC FEET PER SECOND

SURFACE-FLOW DIRECTION OF MAIN CURRENT, 4,200 CUBIC FEET PER SECOND

APPROXIMATE LOCATION OF SEPARATION SURFACES, 4,200 CUBIC FEET PER SECOND

LOCATION OF PROFILE LINES DEPICTED IN FIGURE 12, SEE TABLE 13 
deposit was about $160 \mathrm{ft}^{3} / \mathrm{s}$, which was only 0.4 percent of the main-channel discharge. The measured mean velocities at Eighteen Mile Wash are characteristics of velocities in low-velocity areas measured el sewhere.

Sand transport in the low-velocity area at $45,000 \mathrm{ft}^{3} / \mathrm{s}$ was upstream, away from the primary-eddy return current. Comparison of topographic surveys shows that approximately 13,000 $\mathrm{ft}^{3}$ of very fine and fine sand was deposited between May 22 and the recession of high flows 33 days later. Aggradation occurred by upstream migration of the slipface (fig. 13) and by deposition on the downstream-facing slope. Sedimentary structures within the deposit consisted mainly of climbing ripples in the downstream part and planar foreset beds of the advancing slipface in the upstream part. If the measured volume change resulted from continuous deposition over the 33 days when the deposit was submerged, then the rate of deposition was about $390 \mathrm{ft}^{3} / \mathrm{d}$ or about 0.03 vertical $\mathrm{ft} / \mathrm{d}$. It is possible, however, that deposition occurred more rapidly in only a small percentage of the total inundation period. The low discharge across the deposit and the fact that climbing ripples do not have supercritical angles of climb, however, suggest that the deposition was at a slow rate. Supercritically climbing ripples are ones in which all parts of the ripple surface are preserved. They are associated with high sedimentation rates (Hunter, 1977).

Comparison of currents at Eminence Break Camp (fig. 14) and bathymetric maps (fig. 15) and bed-surface profiles (fig. 16) for high-elevation part of profile 2 between April and September 1985 also shows aggradation in areas upstream from the primary-eddy return-current channel. The area was inundated by a secondary eddy and low-velocity area during the bathymetric surveys made at 26,000 and $27,200 \mathrm{ft}^{3} / \mathrm{s}$ and during the high flows of May and June 1985.

Separation deposits typically have a spit near the junction between the shoreline that faces the main current and the shoreline that faces the recirculation zone, such as the spit at Eminence Break Camp (fig. 14). Observations at National Rapid in June 1985 suggest that these spits form where sediment transported by a primary or secondary eddy is rapidly deposited into a low-velocity area.

Separation deposits are not found downstream from all debris fans. For separation deposits to form, a stage-discharge relation and local topography must result in the existence of a low-velocity area and (or) secondary eddies upstream from the primary-eddy return current at some discharges. Debris fans with steep, high slopes do not typically have separation deposits because no discharges occur at which a low-velocity area or secondary eddy exists. At the study site Above Cathedral Wash, only discharges much greater than $100,000 \mathrm{ft}^{3} / \mathrm{s}$ would overtop the constricting fan. Some fine sediments exist on the talus at elevations associated with floods in excess of $100,000 \mathrm{ft}^{3} / \mathrm{s}$. No lowelevation part of the separation deposit projects downstream, however, because the primary-eddy return current is adjacent to the talus at discharges less than $100,000 \mathrm{ft}^{3} / \mathrm{s}$. In contrast, at Eminence Break Camp, a large low-velocity area exists between the debris fan and the primary-eddy return current at discharges between 21,000 and at least $44,000 \mathrm{ft}^{3} / \mathrm{s}$ (fig. 14, bottom). Mean velocities in this area at Eminence 


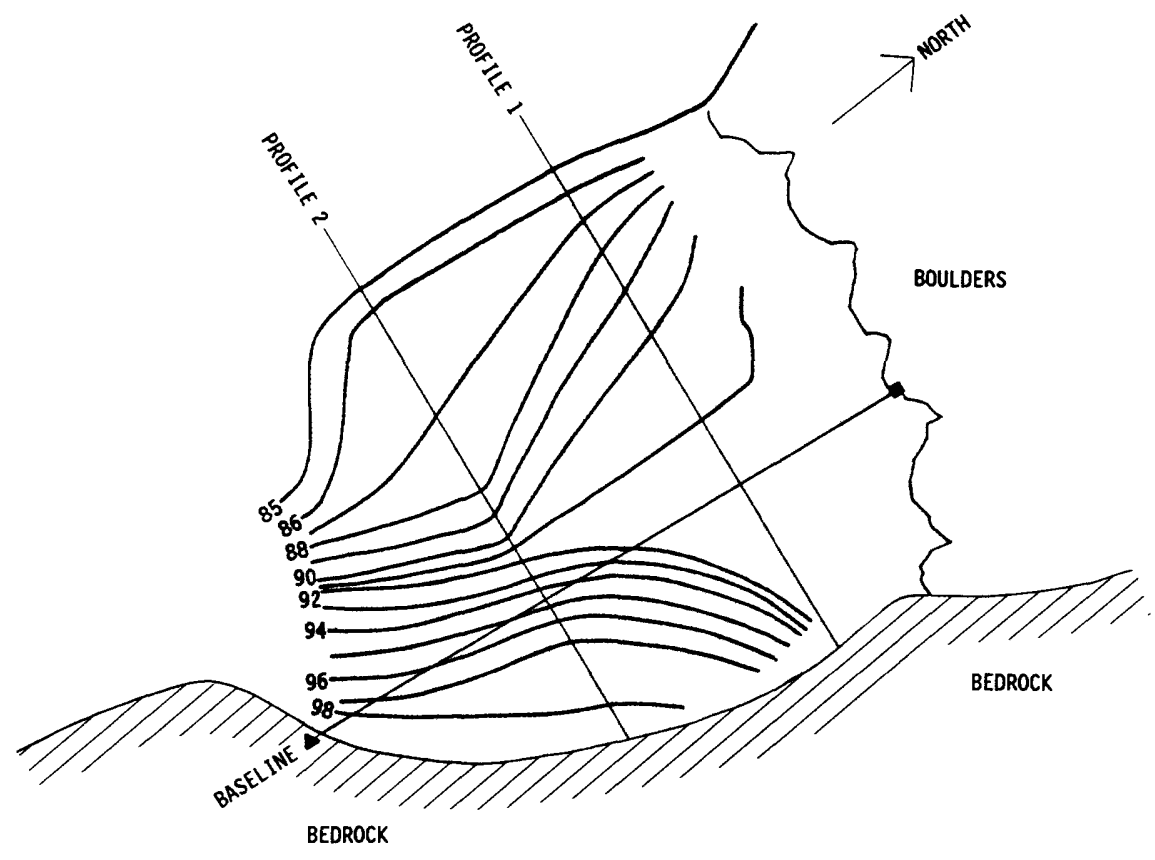

A. JULY 7,1975

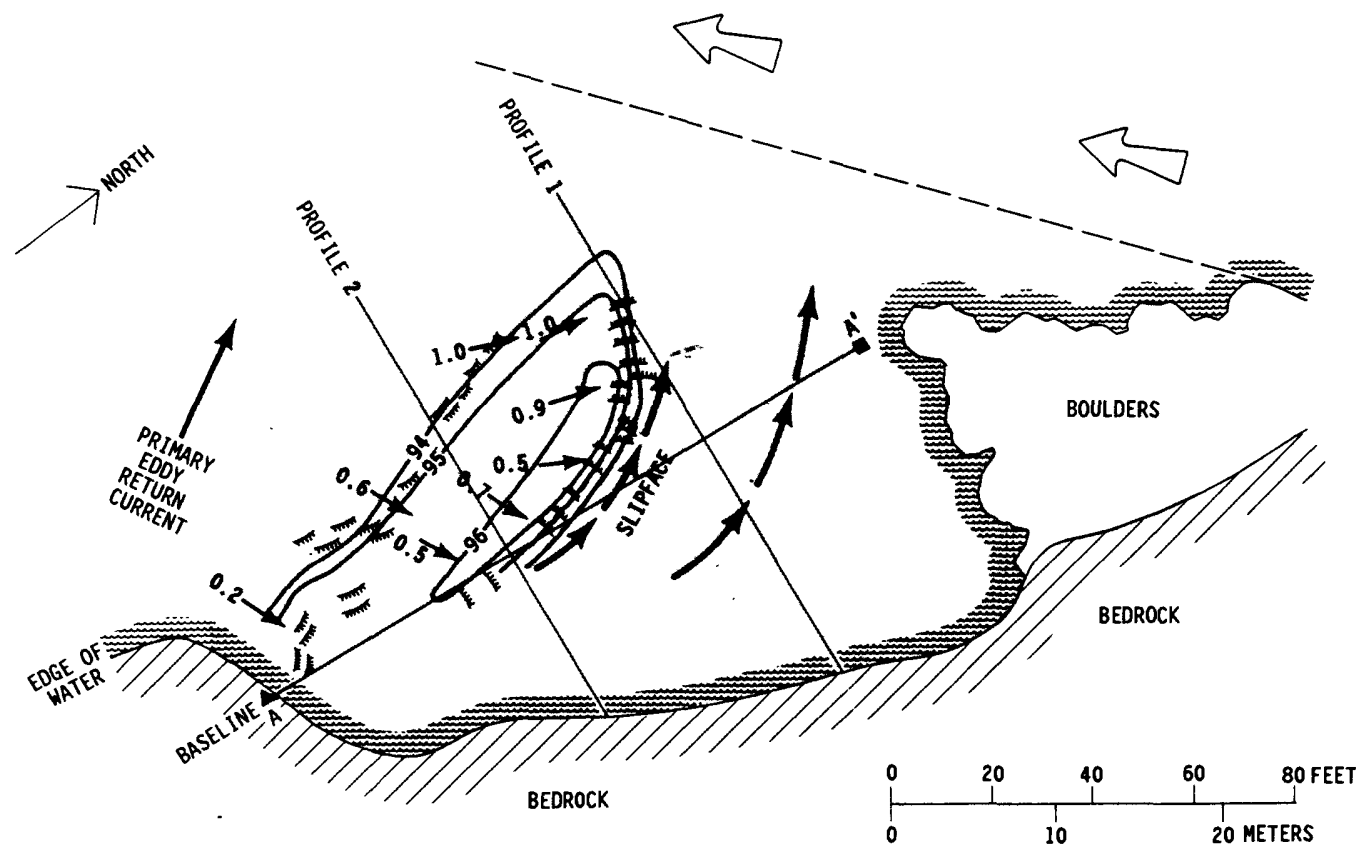

B. MAY 22, 1985

Figure 12.--Topography of separation deposit at Eighteen Mile Wash in 1975 and at selected times in 1985. A, 1975, on the basis of cross-section surveys (Howard, 1975) and ground photography. B, May 22, 1985, discharge 45,000 cubic feet per second. C, August 2, 1985, discharge 30,000 cubic feet per second. $D$, October 9, 1985, discharge 4,100 cubic feet per second. 


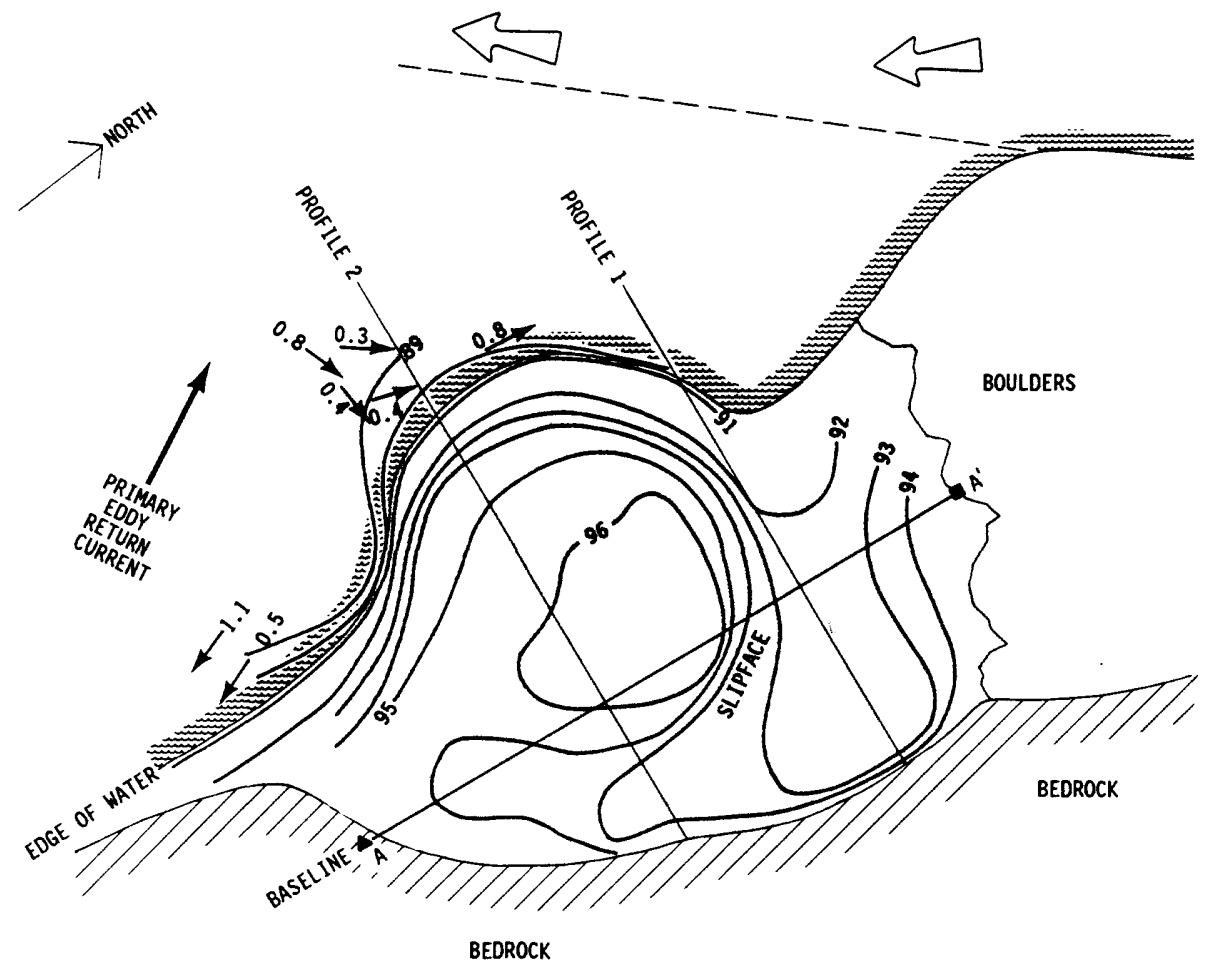

C. AUGUST 2,1985

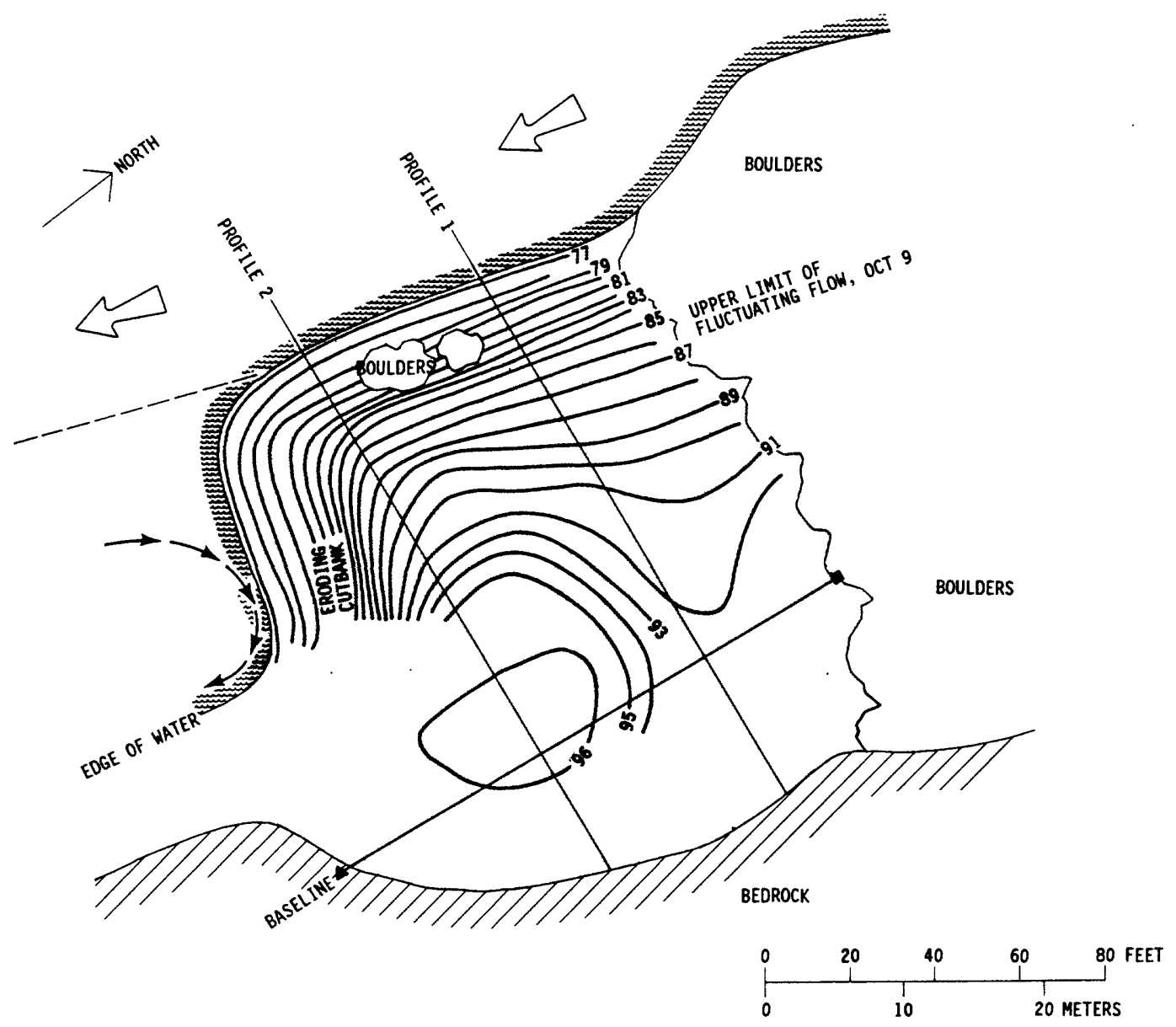

D. OCTOBER 9,1985

Figure 12.--Topography of separation deposit at Eighteen Mile Wash in 1975 and at selected times in 1985. A, 1975, on the basis of cross-section surveys (Howard, 1975) and ground photography. B, May 22, 1985, discharge 45,000 cubic feet per second. C, August 2, 1985, discharge 30,000 cubic feet per second. $D$, October 9,1985 , discharge 4,100 cubic 
EX P L A N A T I O N

51
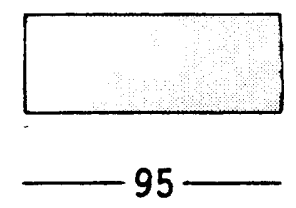

95

$1.1 \rightarrow \quad$ DIRECTION AND MAGNITUDE (IN FEET PER

SECOND) OF MEAN VELOCITY

GENERALIZED SURFACE-FLOW DIRECTION IN

RECIRCULATION ZONES

2

$E \sum$ SLIPFACE OF RIPPLE

- - - SEPARATION SURFACE

- REFERENCE POINT FOR ARBITRARY DATUM-

Elevation, 100 feet.

Figure 12. 
DOWNSTREAM

UPSTREAM

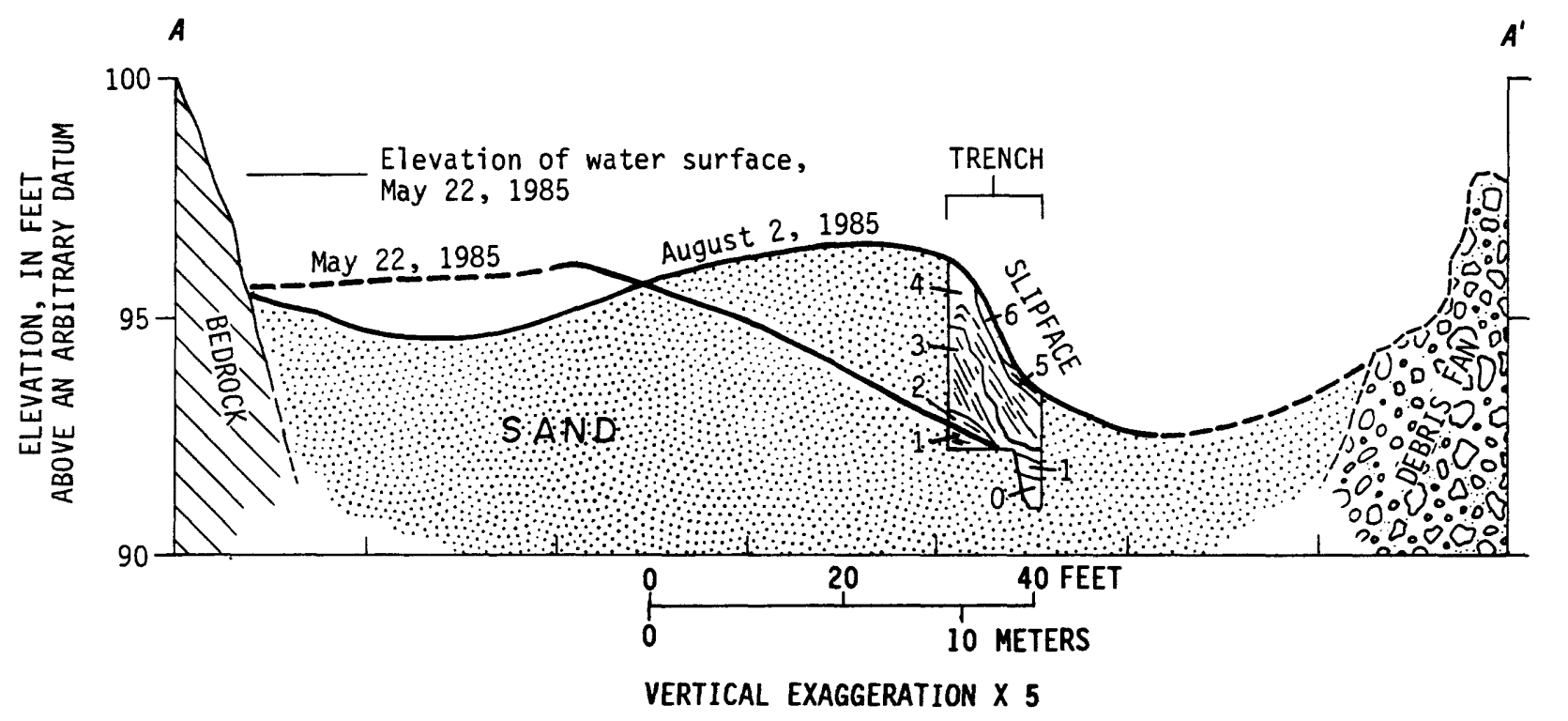

EXPLANATION

6 WINDBLOW SAND

5 FINE TO VERY FINE SAND-Ripple cross lamination in wash, some planar lamination

4 VERY FINE SAND-Complex ripple cross laminae and climbing ripples, grade offslope into organic rich sand

3 FINE SAND-Steep foresets, disturbed upper surface, distinct avalanche laminae below, grades into "structureless" sand in wash below organic rich sand of unit 4

2 FINE TO VERY FINE SAND-Planar foreset laminae and irregular distorted cross laminae in sets

1 FINE TO VERY FINE SAND-Highly truncated ripple cross laminae with organic lenses

0 RED SANDY GRAVEL-1984(?) flash flood deposit

Description by J. N. Moore, University of Montana, August 2, 1985

Figure 13.--Topography and sedimentology associated with upstream advancement of slipface, May 22, 1985, and August 2, 1985, at Eighteen Mile Wash. 
Break Camp were always less than $1.0 \mathrm{ft} / \mathrm{s}$. At Saddle Canyon, separation deposits mantle the upper surface of the debris fan but do not project offshore. Low-velocity areas are present upstream from the primary-eddy return current only at discharges above about $31,500 \mathrm{ft}^{3} / \mathrm{s}$, and the separation deposit is confined to a small high-elevation area (fig. 17).

Separation deposits may be subjected to significant wave action, particularly near steep rapids such as Nevills Rapid at river mile 75.5 and Granite Rapid at river mile 93.5. Howard and Dolan (1981) found that alluvial deposits had been reworked during approximately 10 years of operation of Glen Canyon Dam. Adjustment to the different intensities of current and wave action that exist at different sites had occurred. For example, they found that where nearshore currents exceeded $1 \mathrm{ft} / \mathrm{s}$ or where swash runup exceeded $3 \mathrm{ft}$, parts of the deposit within the zone of fluctuating discharges had low gradients (approximately $3^{\circ}$ to $9^{\circ}$ ) and were composed of medium sand $(0.19 \mathrm{~mm}$ median grain size). Where nearshore currents and swash were less intense, the median grain size was less than $0.14 \mathrm{~mm}$ and gradients exceeded $10^{\circ}$. Sampling of deposits formed in 1983 or 1 ater do not demonstrate this kind of sorting. For example, some of the coarsest deposits reported by Lojko (1985) are at low-energy sites and some of the finest are at high-energy sites. The lack of sorting observed in deposits formed since 1983 is due to the fact that these primary fluvial deposits had not yet been subjected to fluctuating flows when they were sampled.

Separation deposits may be finer than reattachment deposits. Graphic means (Folk, 1968) were calculated for each of 67 samples collected at 22 sites between Lees Ferry and Bright Angel Creek (table 6). The mean value of the graphic means of each of 12 samples of 7 separation deposits deposited after 1983 was $0.17 \mathrm{~mm}$. A similar mean value was computed for 10 samples of 2 reattachment deposits; the sample mean was $0.25 \mathrm{~mm}$. In terms of the total number of samples of these two deposits, the two sample means significantly differ at the 95 -percent confidence level. The small number of sample sites however precludes definitive statistical conclusions. This difference between grain size of separation and reattachment deposits is spatially illustrated at Saddle Canyon. Three samples of separation deposits at elevations associated with discharges in excess of $45,000 \mathrm{ft} 3 / \mathrm{s}$ had graphic means between 0.10 and $0.13 \mathrm{~mm}$ (fig. 17). Samples of reattachment deposits associated with discharges exceeding $25,000 \mathrm{ft}^{3} / \mathrm{s}$ were all equal to or coarser than $0.15 \mathrm{~mm}$. The grain-size difference between separation and reattachment deposits is related to the lower mean velocities associated with lowvelocity areas, which are the depositional environment of separation deposits, in contrast with the higher mean velocities of reattachment point areas.

\section{Reattachment Deposits}

Reattachment deposits occur at the downstream end of many recirculation zones and project upstream as spits (fig. 3). A slipface typically exists along the shoreward side of the spit (fig. 18). The form of these deposits is well displayed in aerial photographs (fig. 14) taken 

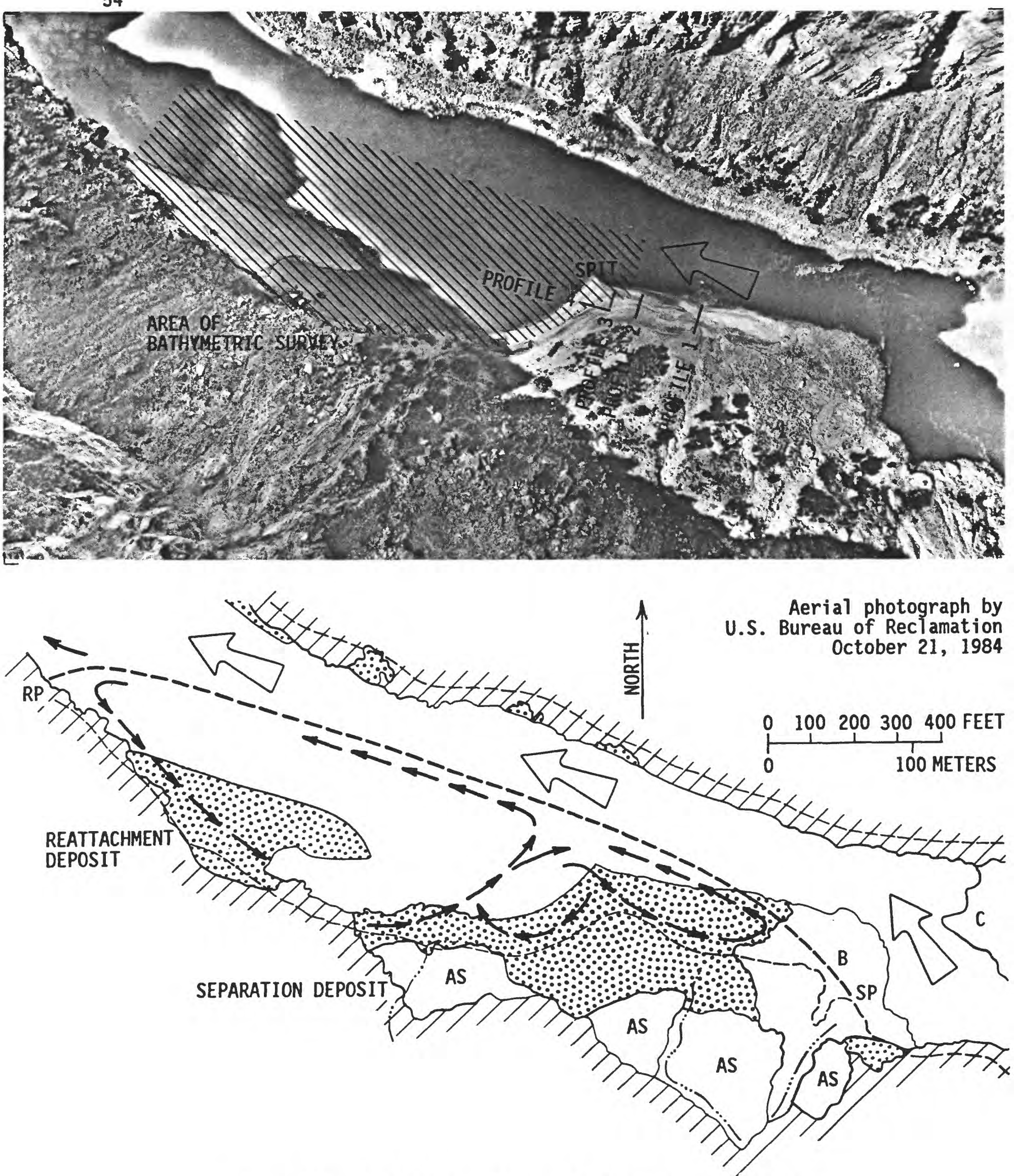

Figure 14.--Surficial geology and hydraulic features at Eminence Break Camp. 
EXPLANATION

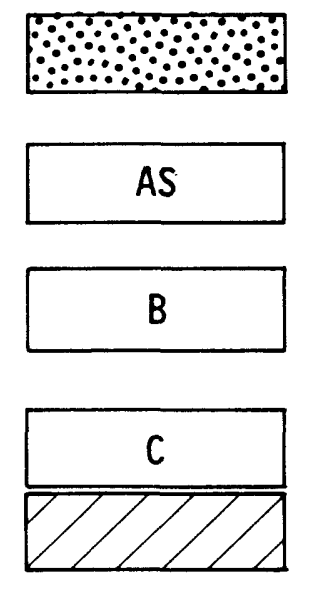

RIVER-DEPOSITED OR REWORKED VERY FINE TO MEDIUM SAND (October 21, 1984)

AEOLIAN SAND OR TERRACE DEPOSITS-Silt and fine sand, well sorted

TRIBUTARY DEBRIS FAN-Boulders, cobbles, gravel, sand, poorly sorted; boulders cover more than 50 percent of surface area except in tributary streambed

COBBLES AND GRAVEL

TALUS AND BEDROCK

EDGE OF WATER-May 25, 1985, 41,000 cubic feet per second

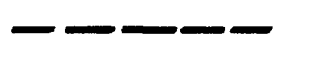

SEPARATION SURFACE-41,000 cubic feet per second

$\longrightarrow \quad$ GENERALIZED SURFACE-FLOW DIRECTION IN

RECIRCULATION ZONES-41,000 cubic feet per second

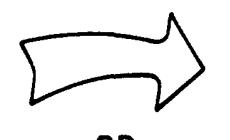

SURFACE-FLOW DIRECTION OF MAIN CURRENT

SP SEPARATION POINT

RP REATTACHMENT POINT

PROFILE $1-$ LOCATION OF PROFILE LINES, SEE TABLE 13 

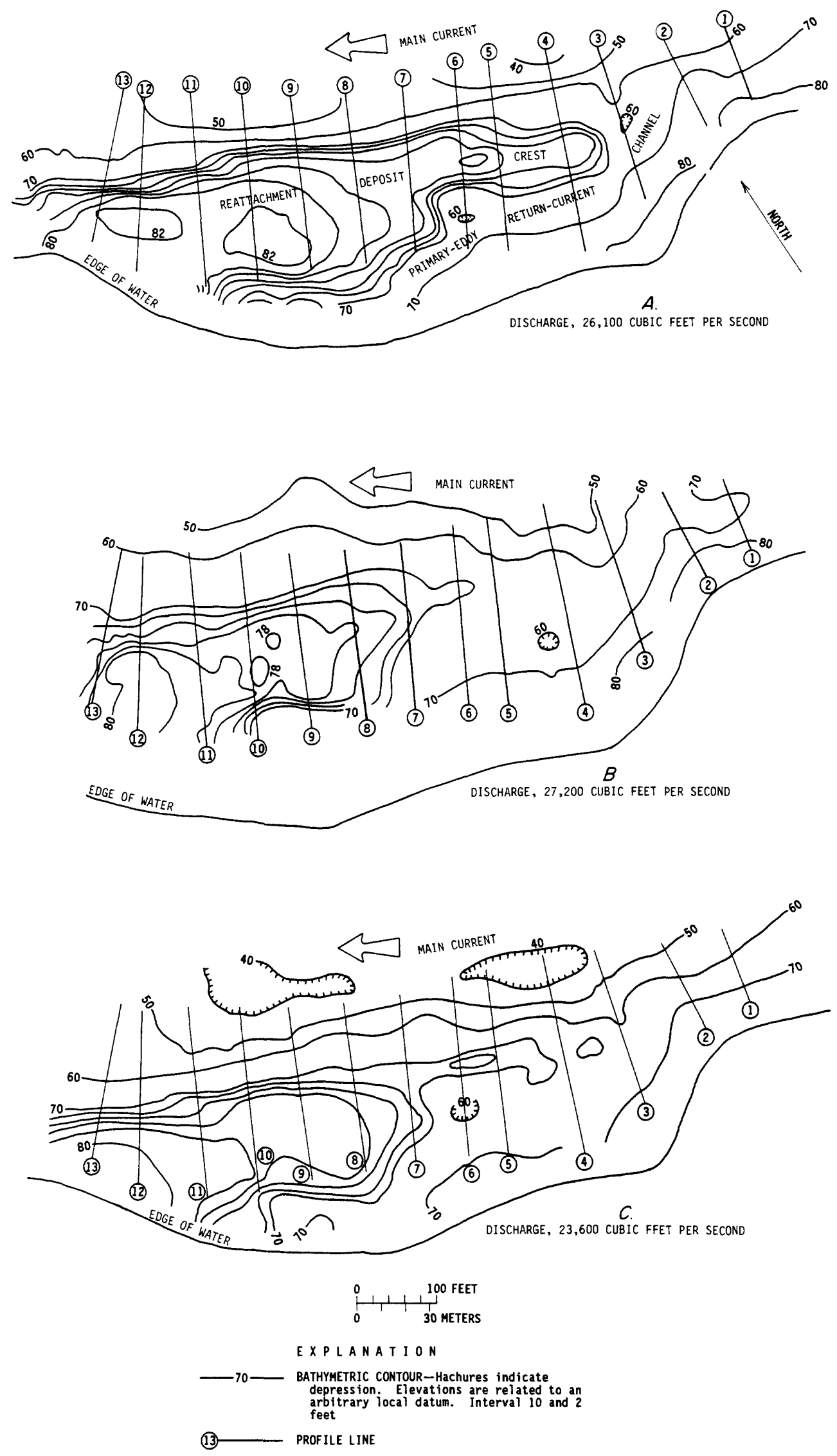

Figure 15.--Bathymetric contours within the recirculation zone at Eminence Break Camp. A, On April 26, 1985. B, On September 2, 1985. C, On January 16, 1986. 


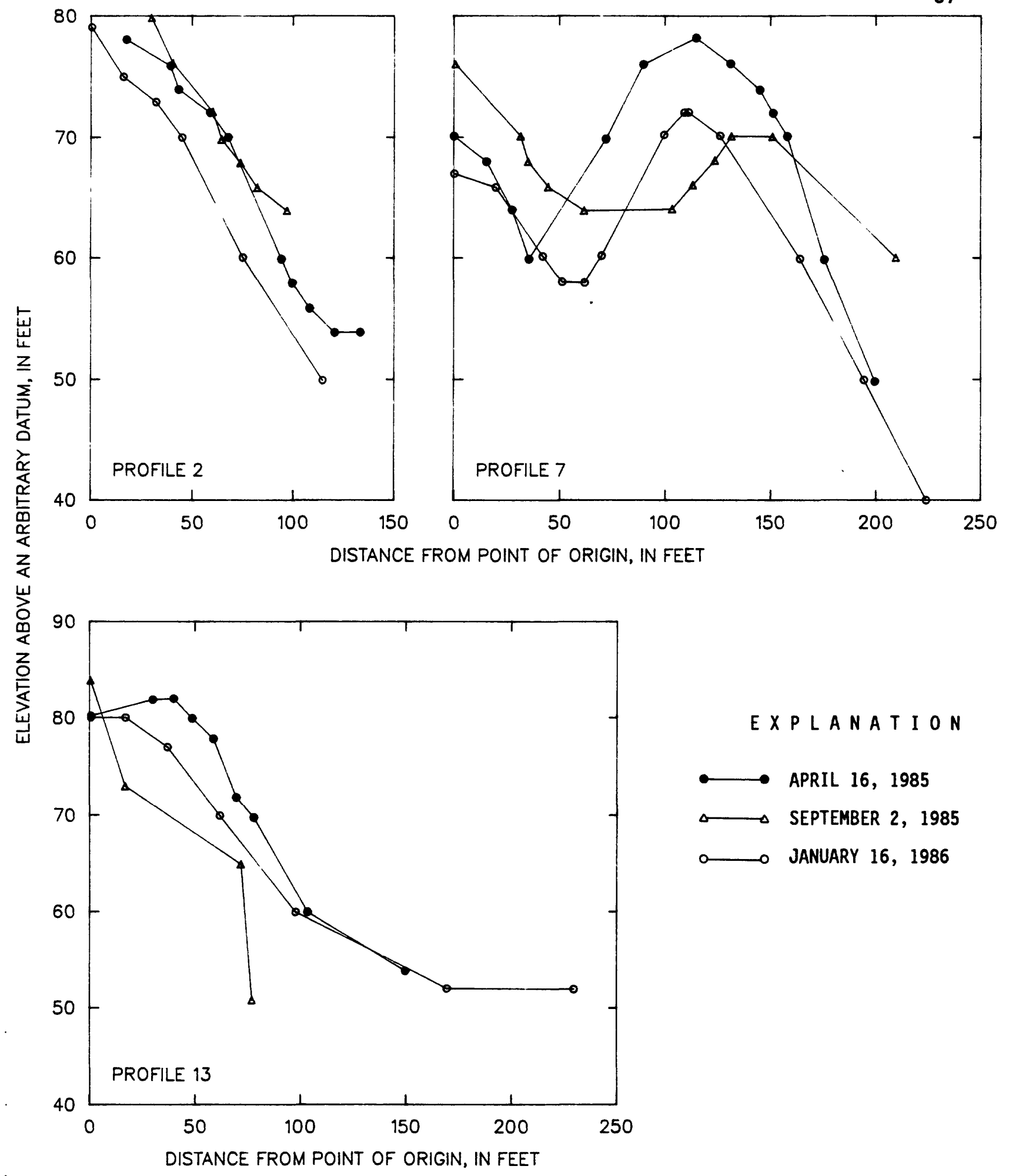

Figure 16.--Bed-surface profiles of a recirculation zone at Eminence Break Camp. 
58

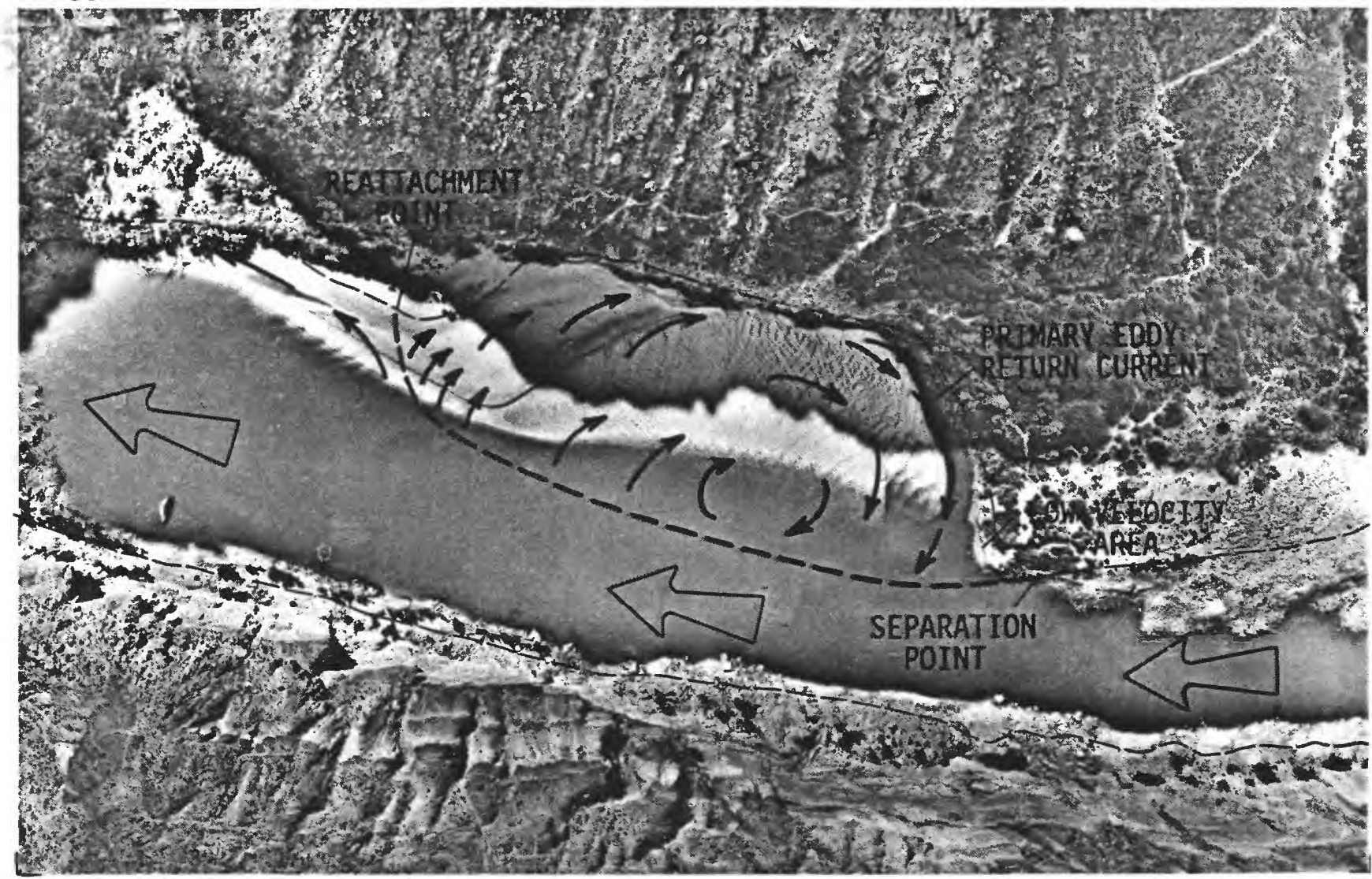

Aerial photograph by

U.S. Bureau of Reclamation

October 21, 1984

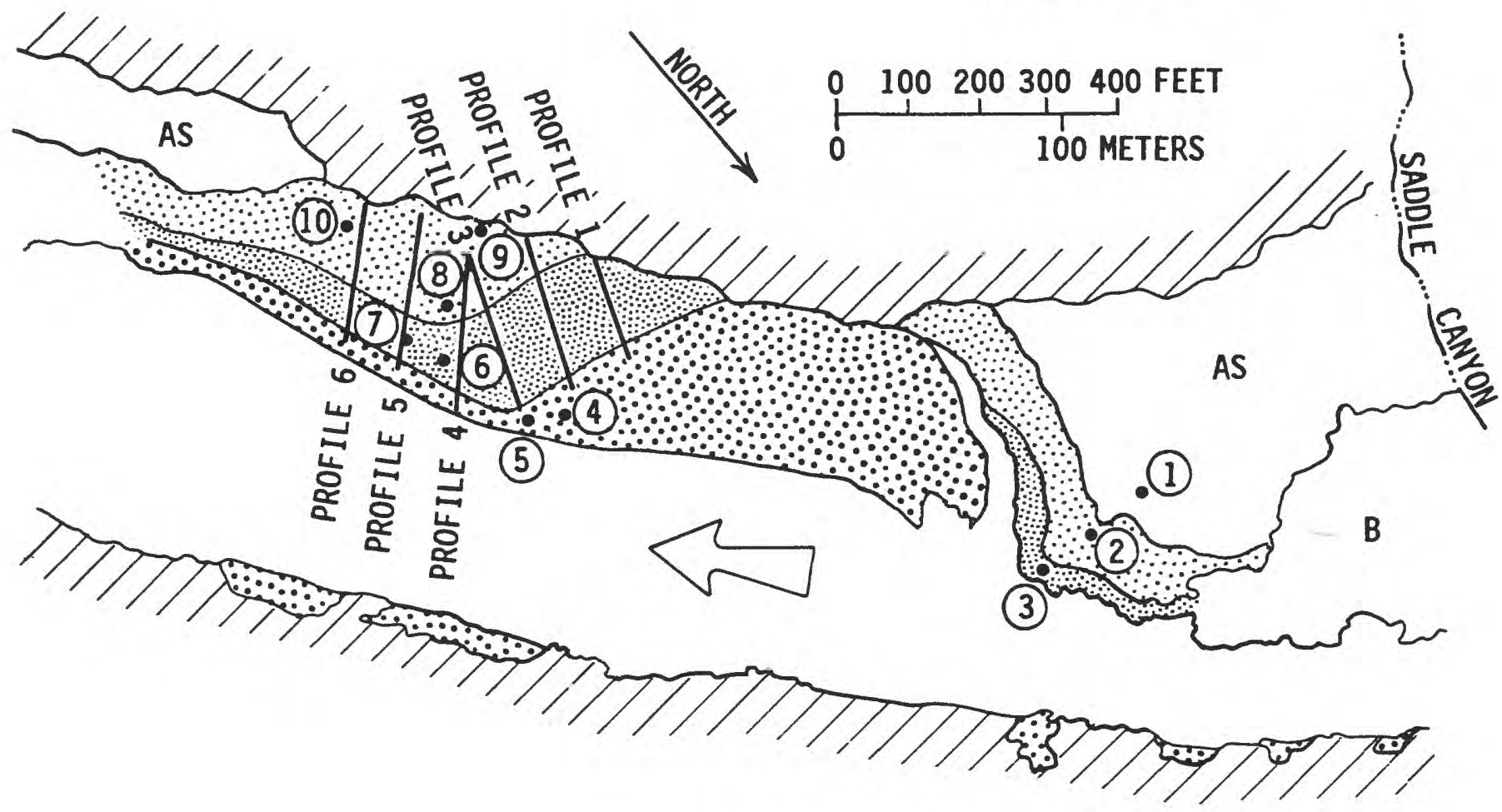

Figure 17.--Surficial geology, hydraulic features, area of sand inundated at different discharges, and sediment-sampling sites at Saddle Canyon. 


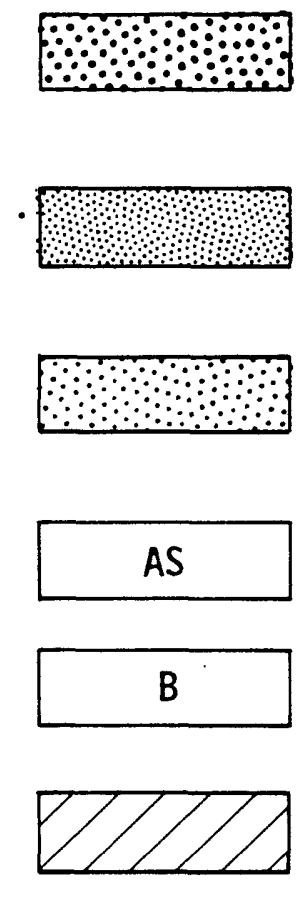

RIVER-DEPOSITED OR REWORKED FINE TO MEDIUM SAND-Inundated by discharges less than 22,000 cubic feet per second

RIVER-DEPOSITED OR REWORKED VERY FINE TO MEDIUM SAND-Inundated by discharges between 22,000 cubic and 48,500 feet per second

RIVER-DEPOSITED OR REWORKED VERY FINE TO FINE SAND-Inundated by discharges between 48,500 cubic and 97,300 feet per second

AEOLIAN SAND OR TERRACE DEPOSITS-Silt to fine sand, well sorted

TRIBUTARY DEBRIS FAN-Boulders, cobbles, gravel, sand, poorly sorted; boulders cover more than 50 percent of surface area except in tributary streambed

TALUS AND BEDROCK

EDGE OF WATER-May 15, 1986, 48,500 cubic feet per second

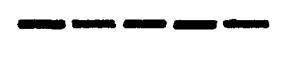

$\longrightarrow \quad$ GENERALIZED SURFACE-FLOW DIRECTION IN

RECIRCULATION ZONES-48,500 cubic feet per second

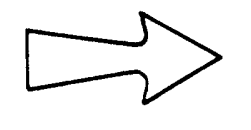

SURFACE-FLOW DIRECTION OF MAIN CURRENT

(2)

SEDIMENT SAMPLE SITE, TABLE 5

$$
\begin{aligned}
& 1-J C S 13 \\
& 2-J C S 14 \\
& 3-J C S 15 \\
& 4-J C 55,6,7 \\
& 5-J C S 8,9 \\
& 6-J C S 10 \\
& 7-J B G 17,18 \\
& 8-J C S 11 \\
& 9-J C S 12 \\
& 10-J B G 16
\end{aligned}
$$

Figure 17. 
at low discharges of about $6,000 \mathrm{ft}^{3} / \mathrm{s}$. These deposits were directly observed during clear-water flows at discharges of 30,000 and $45,000 \mathrm{ft}^{3} / \mathrm{s}$ and were mapped during bathymetric surveys at discharges of 15,000 to $25,000 \mathrm{ft}^{3} / \mathrm{s}$. Although the deposits tend to move and adjust to changing discharge, the basic shape remains the same.

Reattachment deposits form in primary eddies and build upstream from the reattachment point. Direct observations of surface-current patterns, migrating bedforms, and bedform-migration directions exposed in trenches show that sand transport over most of these deposits is away from and perpendicular to the main current direction. Sand is transported across the top of the deposit, cascades down the slipface, and is swept upstream by the primary-eddy return current.

Reattachment deposits fill recirculation zones to a varying extent. The low flows of October 1984 (fig. 9) exposed much of the bed of the recirculation zone at some locations (fig. 17), whereas at other locations, only a part of the deposit was exposed. Comparison of the area of reattachment deposit exposed at low discharge in 1973 with the area exposed in 1984 for selected sites shows that at sites where exposed area decreased, the decrease occurred in the upstream part of the deposit (fig. 19). Topographic and side-scan sonar data indicate that decrease in exposed area is due to (1) loss of sand from recirculation zones and (2) redistribution of the same mass into a smaller area of higher relief.

The topography of a typical reattachment deposit consists of a mound of sand or crest near the center of the deposit and a lower elevation extension of the crest downstream and onshore (fig. 18). A third area of higher elevation formed by high discharges may exist farther downstream.

The higher parts of reattachment deposits typically extend the farthest downstream. This pattern is related to the hydraulic changes in recirculation zones that occur with decreasing discharge. Reattachment points typically migrate downstream with increasing discharge and migrate upstream as discharge subsequently decreases (fig. 5 ). Therefore, alluvial deposits created at the highest discharges near the high-discharge reattachment point are abandoned by the recirculation zone as it decreases in size. Any downstream part of the sand deposit is subjected to downstream-directed flow, and eroded sand from these high banks is deposited in the main channel and not in the recirculation zone (fig. 20). Erosion or redistribution of sand upstream from the migrating reattachment point results in redistribution of sand within the recirculation zone and upstream migration of the slipface. Fluctuating flows may result in further redistribution of sand within recirculation zones. The crest of a reattachment deposit formed under steady flows may be changed to a gently sloping continuous surface under fluctuating flows, such as occurred at Blacktail Rapid (figs. 21, 22, and 23). The farthest downstream part of the reattachment deposit nearly always degrades during fluctuating flows. For example, surveys at Blacktail Rapid (fig. 23, profile 1) and One Hundred and Twenty-Two Mile Creek showed significant bank retreat in this area between October 1985 and January 1986.

The effect of flow recession and recirculation zones that decrease in length on erosion of downstream parts of reattachment deposits 
Table 6. --Summary statistics of particle-size characteristics

\begin{tabular}{|c|c|c|c|c|c|}
\hline $\begin{array}{c}\text { Time } \\
\text { of } \\
\text { deposition }\end{array}$ & $\begin{array}{l}\text { Deposit } \\
\text { type }\end{array}$ & $\begin{array}{c}\text { Number } \\
\text { of } \\
\text { samples }\end{array}$ & $\begin{array}{l}\text { Mean } \\
\text { graphic } \\
\text { mean } \\
\text { value, } \\
\text { in } \\
\text { milli- } \\
\text { meters }\end{array}$ & $\begin{array}{c}\text { Standard } \\
\text { deviation } \\
\text { of graphic } \\
\text { means, } \\
\text { in } \\
\text { milli- } \\
\text { meters }\end{array}$ & $\begin{array}{c}\text { Ninety-five } \\
\text { percent } \\
\text { confidence } \\
\text { interval, } \\
\text { in } \\
\text { milli- } \\
\text { meters }\end{array}$ \\
\hline $\begin{array}{l}\text { Pre-dam } \\
\text { Post } 1983 \\
\text { Pre-dam } \\
\text { Post } 1983 \\
\text { Pre-dam } \\
\text { Post } 1983 \\
1985\end{array}$ & $\begin{array}{l}\text { Separation } \\
\text { Separation } \\
\text { Reattachment } \\
\text { Reattachment } \\
\text { Channel margin } \\
\text { Channel margin } \\
\text { Recirculation } \\
\text { zone bedload }\end{array}$ & $\begin{array}{r}3 \\
12 \\
2 \\
10 \\
7 \\
24 \\
8\end{array}$ & $\begin{array}{l}0.140 \\
.165 \\
.102 \\
.251 \\
.068 \\
.169 \\
.299\end{array}$ & $\begin{array}{l}0.020 \\
.054 \\
.040 \\
.073 \\
.028 \\
.050 \\
.025\end{array}$ & $\begin{array}{c}0.117-0.162 \\
.134-.196 \\
.047-.157 \\
.206-.296 \\
.057-.079 \\
.149-.189 \\
.282-.316\end{array}$ \\
\hline
\end{tabular}

'Small sample sizes restrict statistical significance of data in some categories. Statistics are reported for descriptive purposes.

was observed at Stone Creek where a steady discharge of about $40,000 \mathrm{ft}^{3} / \mathrm{s}$ decreased to about $35,000 \mathrm{ft}^{3} / \mathrm{s}$ in June 1985. Overnight, a cutbank downstream from the new reattachment point retreated 2.75 to $3.5 \mathrm{ft}$ and degraded about $1 \mathrm{ft}$. Two months later, the entire bar had been uniformly degraded to a new lower level.

Substantial reworking of reattachment deposits may occur at high discharges. At the site Above Cathedral Wash, a truncated pre-1983 deposit was exposed in a trench, indicating that sand close to the river channel had been transported and redeposited since deposition of the older buried surface (fig. 24). Opposite Nineteen Mile Canyon, a similar buried pre-1983 surface was eroded but not entirely truncated. The existence of major truncation surfaces within reattachment deposits and the evidence that some reattachment deposits were significantly eroded by the 1983 high flows (See section entitled "Aggradation and Degradation of Alluvial Sand Deposits, 1965-86") indicate that much of the sand in reattachment deposits is scoured, transported, and redeposited by high discharges. The form and sedimentology of reattachment deposits demonstrate that the final form is determined during flow recession. The discharge and sediment-transport characteristics of that recession, therefore, are important in determining the form and extent of the resulting deposit.

Bedload samples were collected using a wading-type Helley-Smith sampler (Helley and Smith, 1971) in recirculation zones below Kwagunt Rapid (river mile 56) and above the confluence with the Little Colorado River (river mile 60) (table 5). These sites generally are representative 


\section{2}

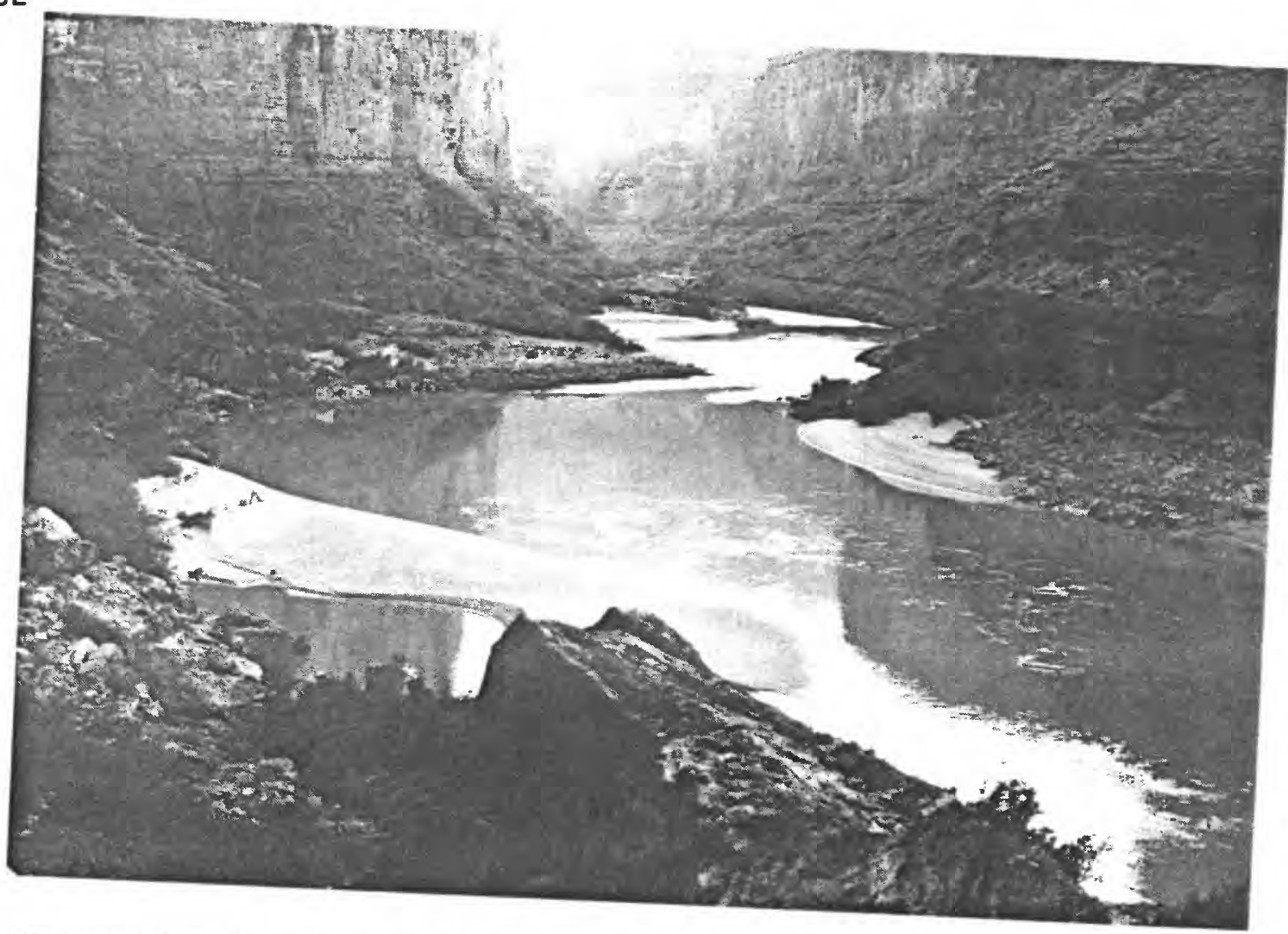

Figure 18. - - Reattachment deposit at Eminence Break Camp, October 12,
1985, discharge 3,000 cubic feet per second. 

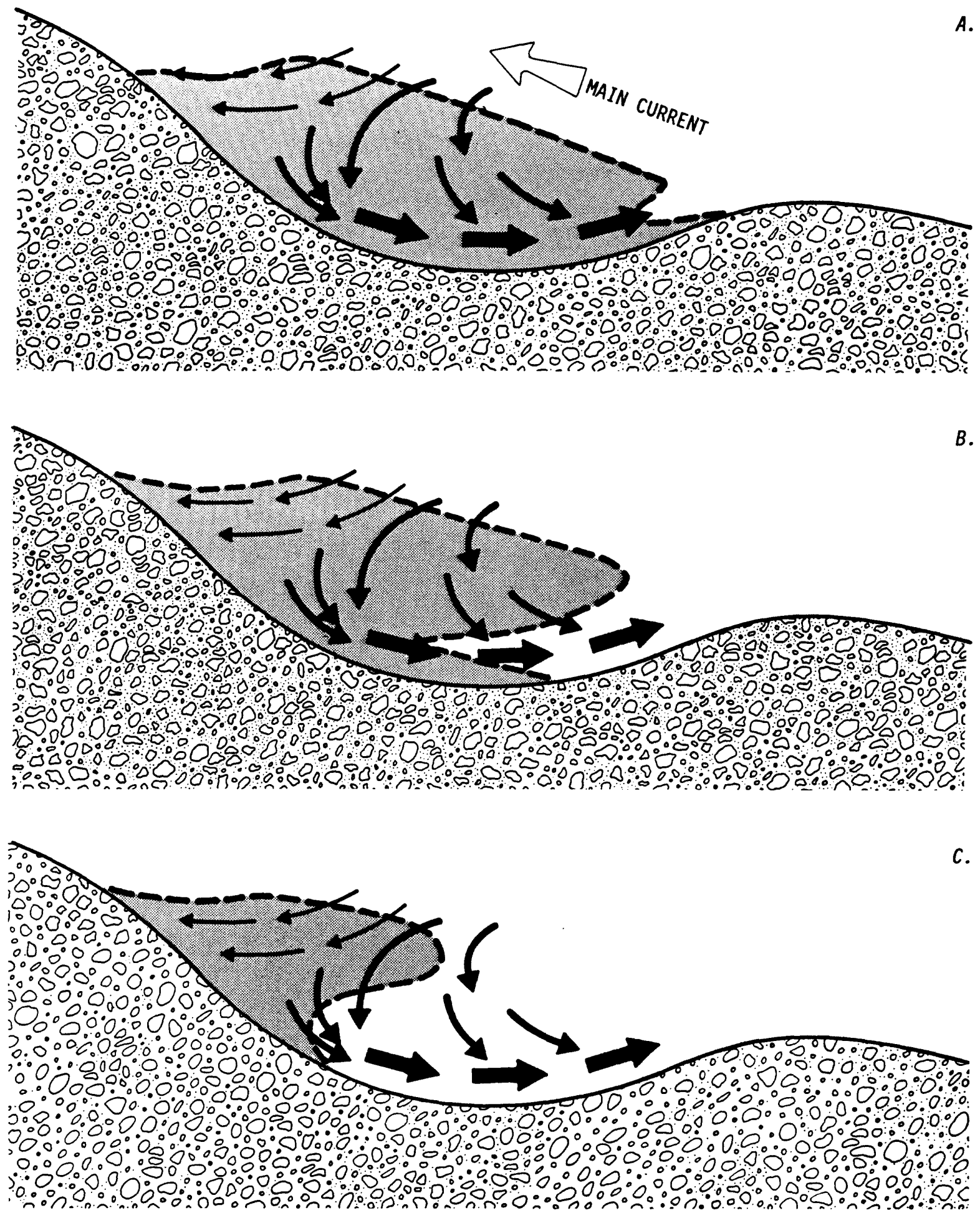

EXPLANATION

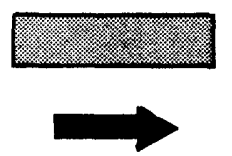

REATTACHMENT DEPOSIT

DIRECTION OF FLOW NEAR REATTACHMENT

DEPOSIT-Proportioned to volume of

flow; largest arrows, greatest volume

of flow

Figure 19.--Reattachment deposit at low discharge. $A$ and $B$, Pattern typical of the mid-1970's. C, Typical pattern following recession of high flows in 1984 and 1985; smaller area of exposed sand may be of higher elevation than larger exposed areas of the mid-1970's. 


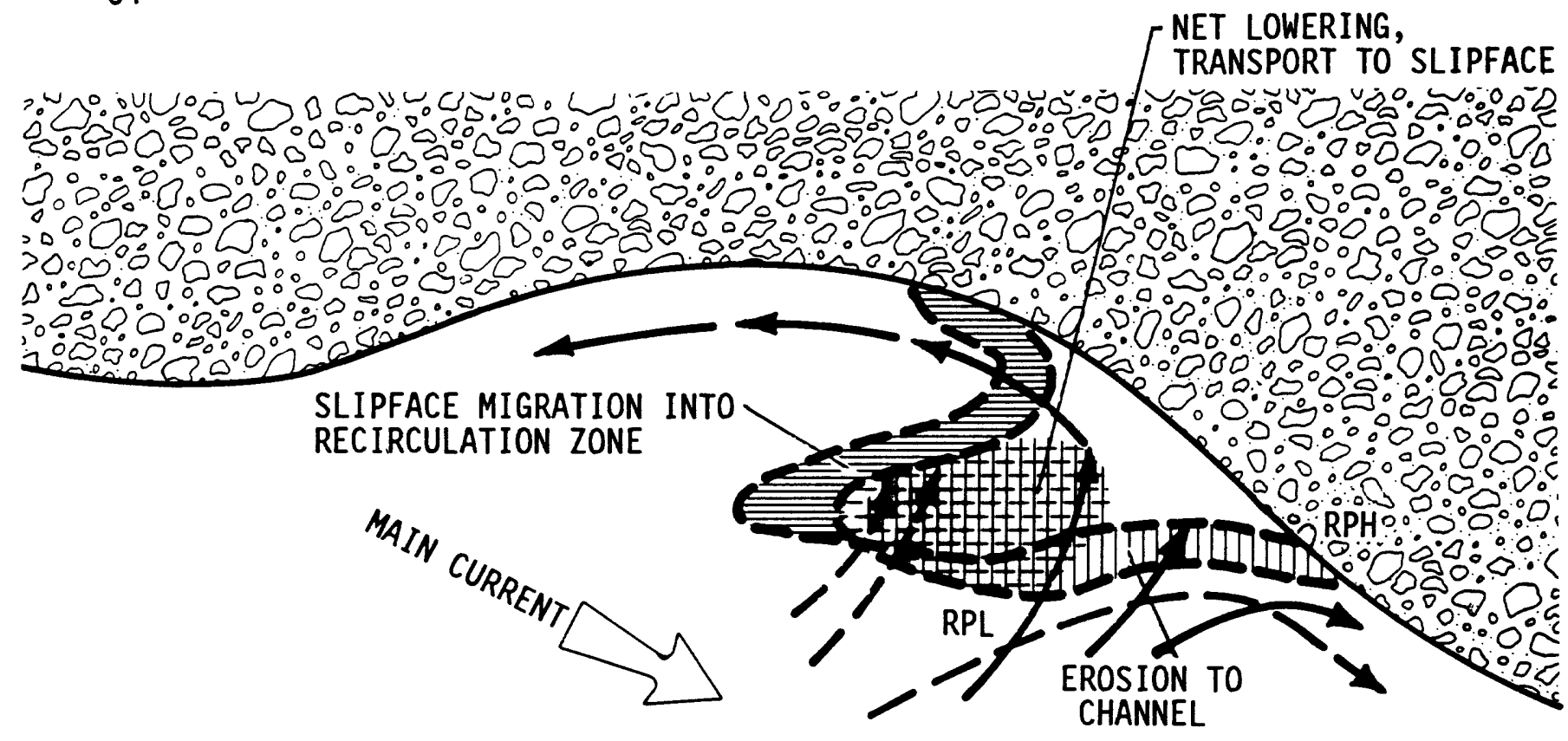

EXPLANATION

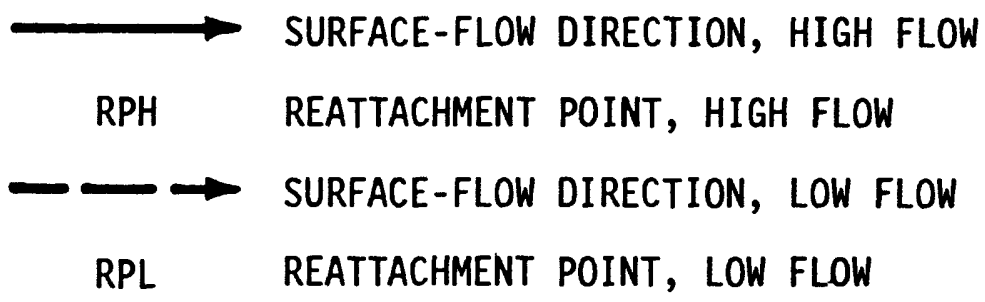

Figure 20.--Response of a reattachment deposit to decreasing discharge. 

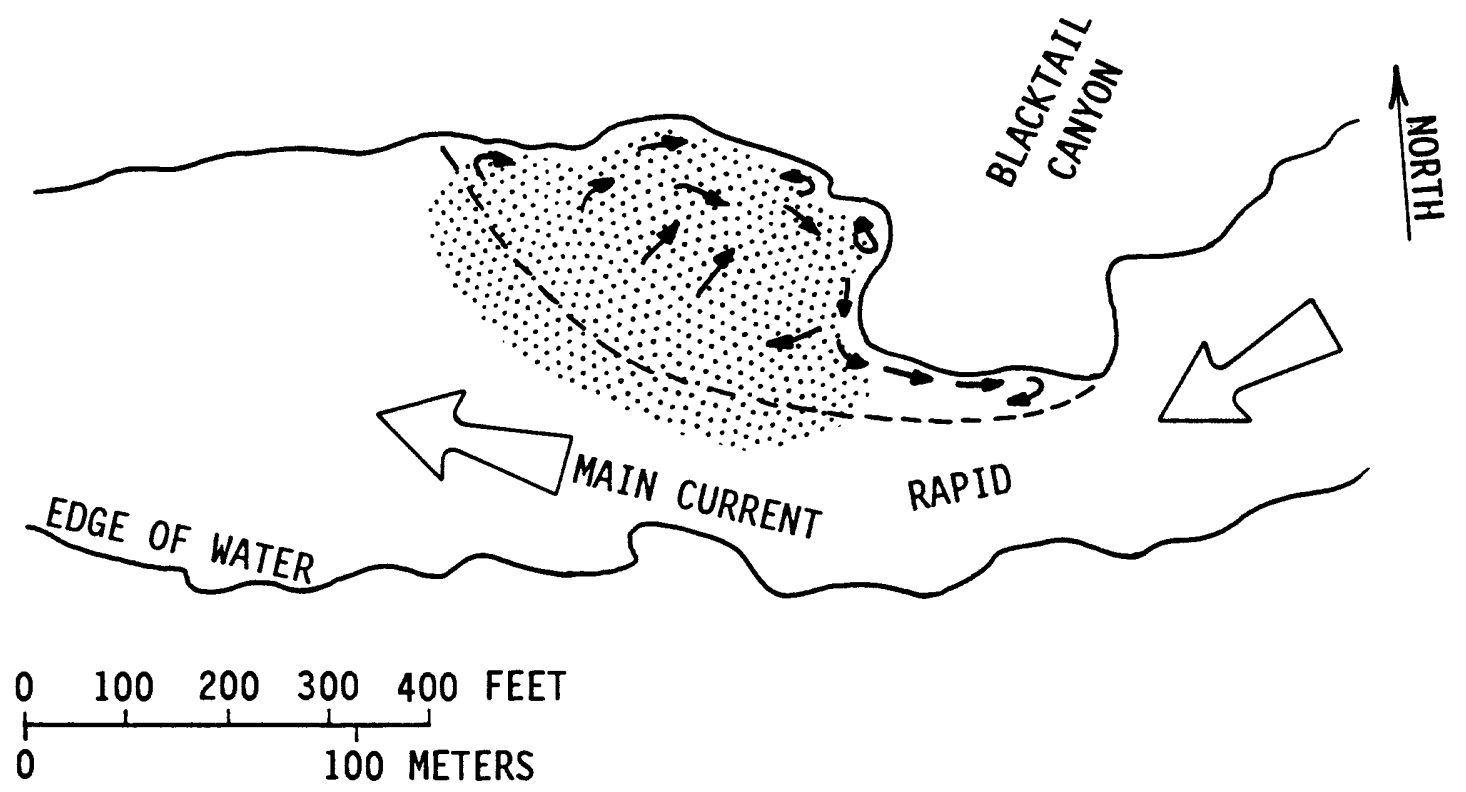

EXPLANATION

- - LOCATION OF SEPARATION SURFACE, 20,000 CUBIC FEET PER SECOND, AUGUST 12, 1985

$\longrightarrow \quad$ GENERALIZED SURFACE-FLOW DIRECTION IN RECIRCULATION ZONE, 20,000 CUBIC FEET PER SECOND

AREA OF BATHYMETRIC SURVEYS

Figure 21.--Area of bathymetric surveys and hydraulic features at Blacktail Rapid. 
EXPLANATION

- 2070- BATHYMETRIC CONTOUR-Hachures indicate depression. Elevations are related to National Geodetic Vertical Datum of 1929. Interval 10 and 2 feet

(2) PROFILE LINE

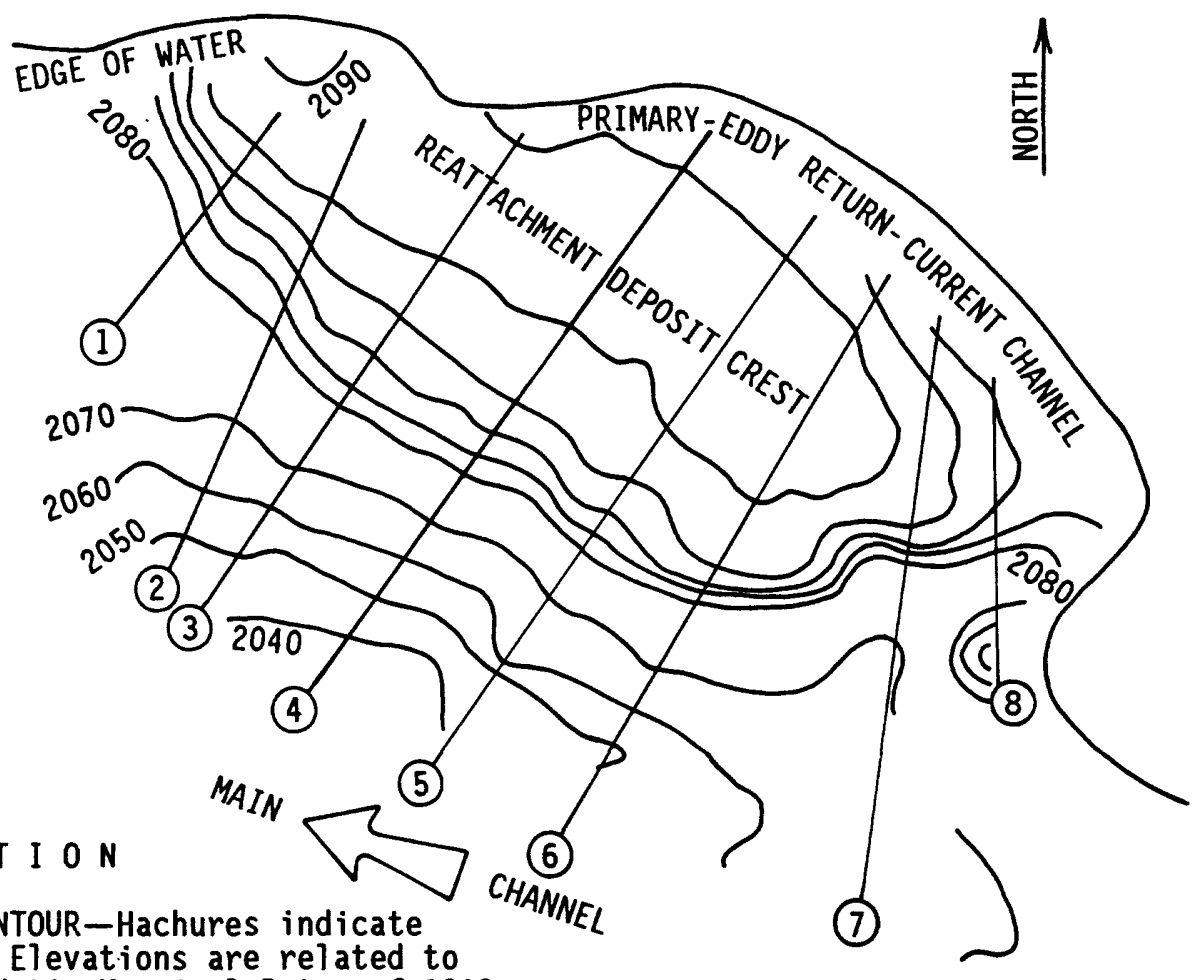

A.
Discharge, 22,600

cubic feet per second

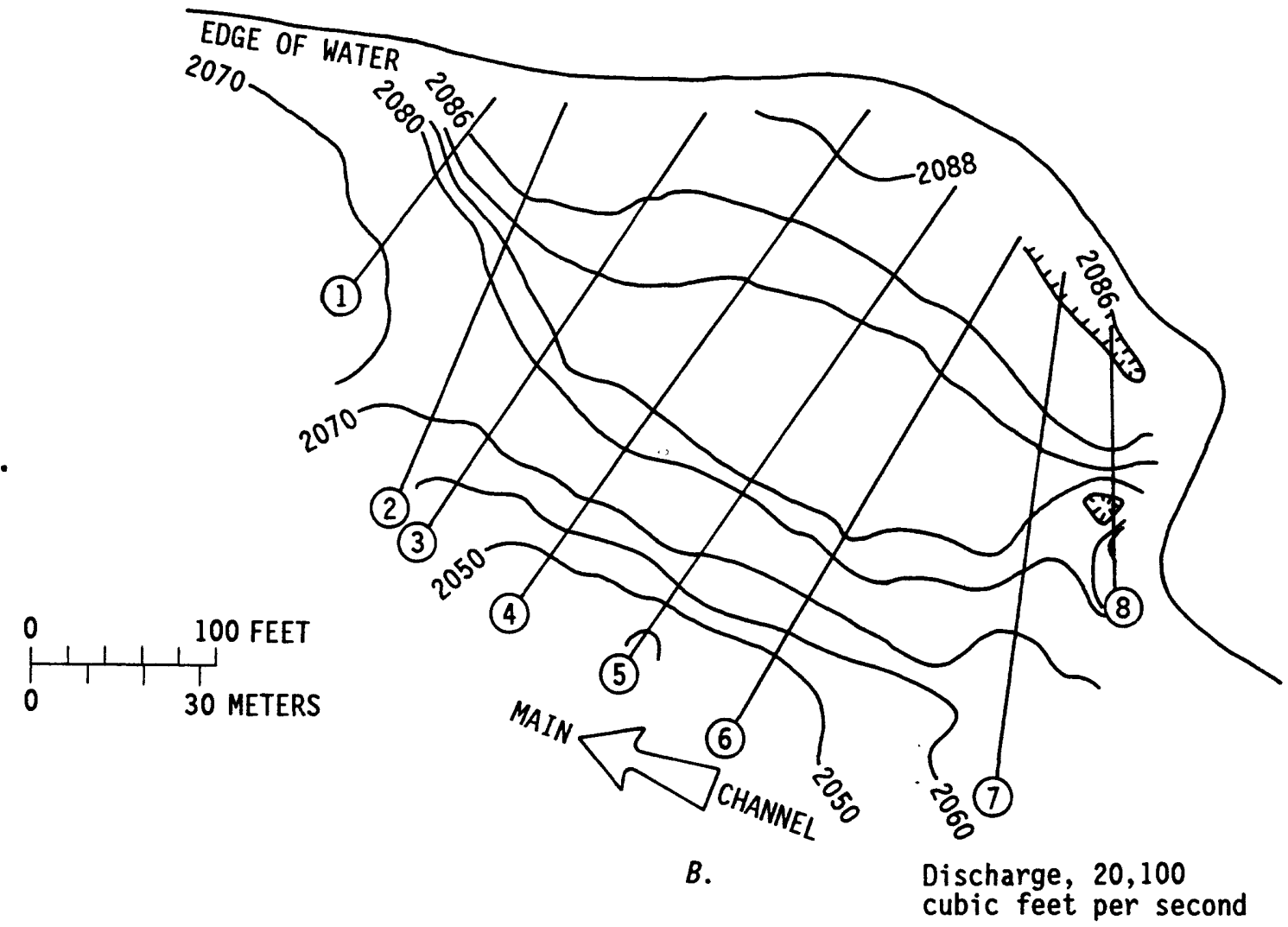

Figure 22.--Bathymetric contours within a recirculation zone below Blacktail

Rapid. A, On September 7, 1985. B, On January 24, 1986. 

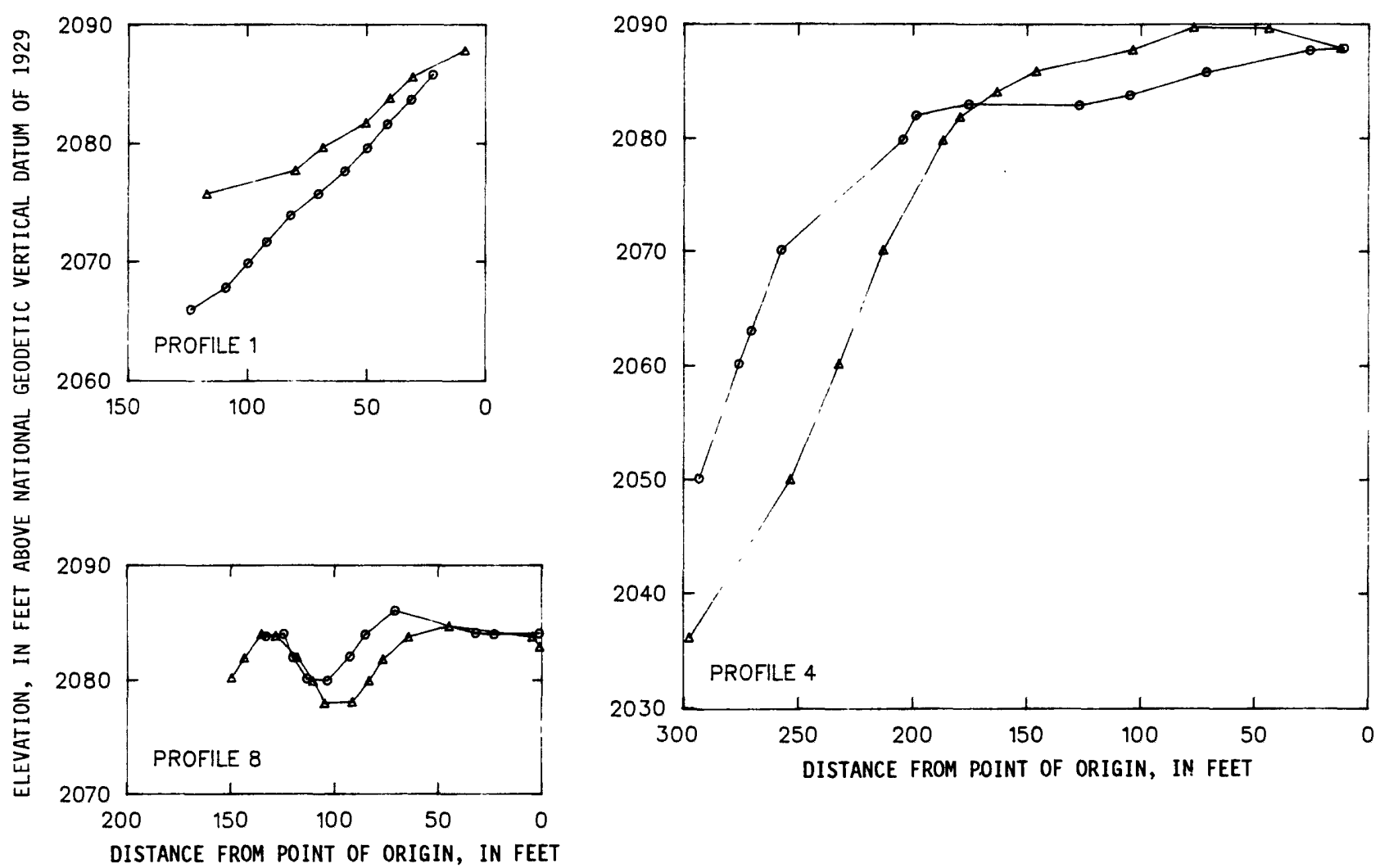

EXPLANATION

$\begin{array}{ll}\triangle & \text { SEPTEMBER } 7,1985 \\ \square & \text { JANUARY } 24,1986\end{array}$

Figure 23.--Bed-surface profiles of recirculation zone below Blacktail Rapid. 


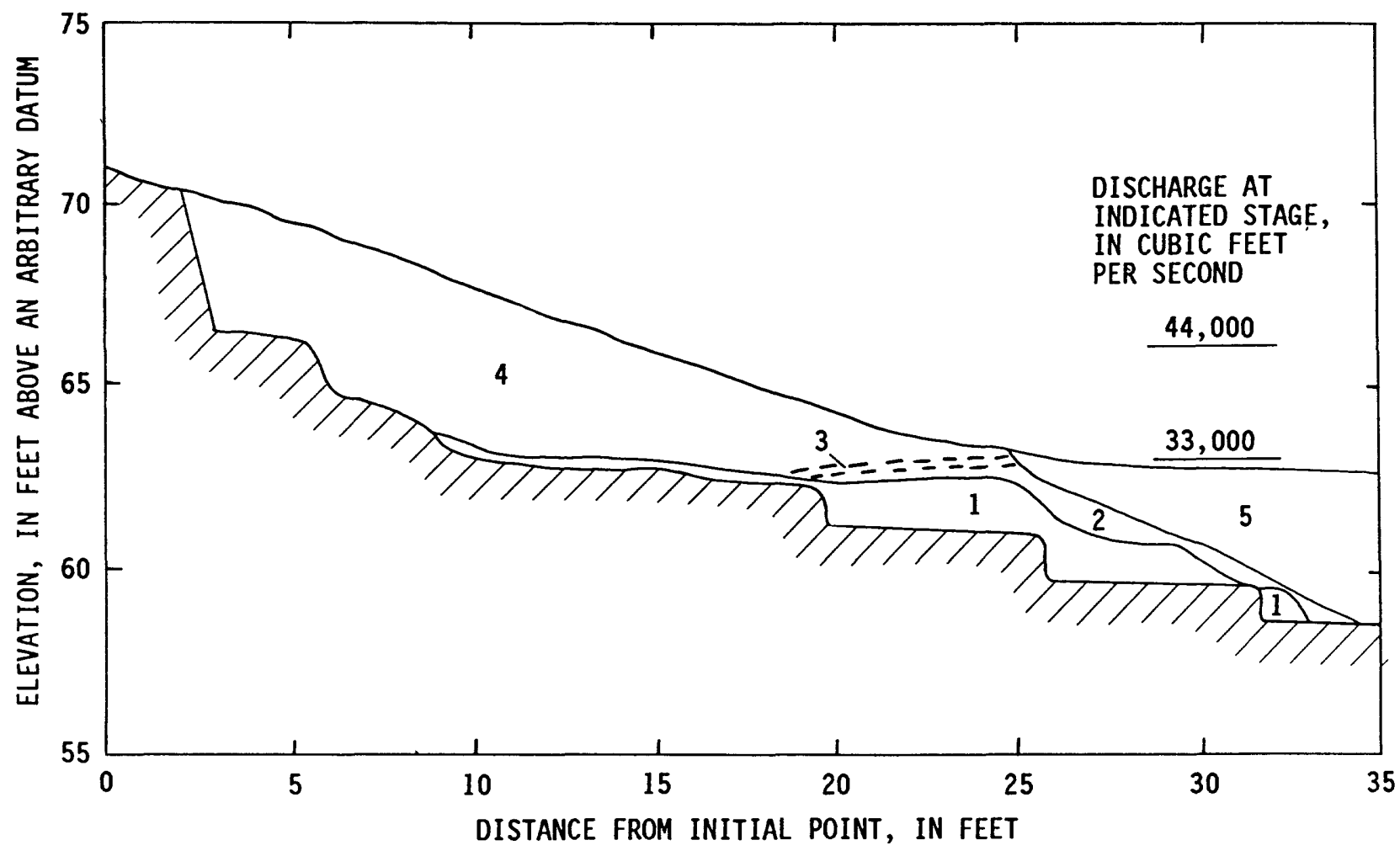

EXPLANATION

5 FINE TO MEDIUM SAND-Current ripples that migrate upstream on foresets that dip toward river, amplitude of current ripples decreases upslope

4 FINE SAND-Current ripples, current direction ups tream away from main channel

3 INTERBEDDED FINE SAND AND SILT-Unit dips at low angle away from main channel or in downstream direction. Entire unit grades upward into unit 4

2 FINE SAND-Generally massive with abundant roots and organic debris, includes an organic rich lens that dips toward main channel. Laminae above the lens is contorted. Entire unit grades upward into unit 3 and pinches out 17 feet from initial point

1 BLACK AND GRAY CLAYEY AND SILTY FINE SAND-Layers of sand define irregular bedding, upper contact is erosional and includes a vertical cutbank 33 feet from initial point. Interpreted to be pre-1983 deposit

Description by T. R. Clifton, University of California, Santa Cruz, January 9, 1986

Figure 24.--Sedimentology exposed in a trench through the reattachment deposit at the site Above Cathedral Wash. 
of recirculation zones at moderate discharges of about $28,000 \mathrm{ft}^{3} / \mathrm{s}$. Mean velocities probably were less than $2 \mathrm{ft} / \mathrm{s}$ where samples were collected. At both sites, the samples collected were well-sorted medium sand (mean value of samples $0.30 \mathrm{~mm}$ ). Coarser sand, therefore, was in transport at a discharge of $28,000 \mathrm{ft}^{3} / \mathrm{s}$ in the recirculation zones than is found in typical separation or reattachment deposits. This comparison suggests that separation and reattachment deposits can be redistributed in at least some recirculation zones at moderate discharges.

Reattachment deposits tend to be coarser than separation deposits (table 6). Reattachment deposits may also coarsen with decreasing elevation at a site, such as at Saddle Canyon (fig. 17). Three samples of 1983 deposits at that site are fine (table 5, JCS-10, JCS-11, JBG-18) or medium (JBG-17) sand. Samples from areas inundated by flows less than $25,000 \mathrm{ft}^{3} / \mathrm{s}$ (table 5, JCS-6, JCS-7, JCS-8, JCS-9) are medium sand except for one sample (JCS-5) of a rippled veneer of very fine sand. This latter deposit is representative of mainstem deposition when tributaries are contributing sediment to the Colorado River.

\section{Upper-Pool Deposits}

Upper-pool deposits line the channel banks upstream from many debris-fan constrictions. The deposits are used as campsites where vegetation has been cleared or where tamarisk trees do not densely cover an area, such as above North Canyon Rapid at river mile 20.3 and above Crystal Rapid at river mile 98.0. In plan view, these deposits are linear and parallel to the channel, consist of different terrace levels, and typically have a low-elevation spit that projects into the channel in an upstream direction. Where spits exist, they are associated with small recirculation zones upstream from a rapid and are formed by the same processes that form reattachment deposits.

High-elevation parts of upper-pool deposits probably are created by low-velocity downstream-directed overbank flows. An example of an upper-pool deposit is the campsite upstream from Granite Rapid. This deposit is adjacent to the pool above the rapid. Plan-view form of the deposit exposed at low flow includes a spit projecting upstream into the channel with a slipface on the shoreward side. At about $25,000 \mathrm{ft}^{3} / \mathrm{s}$ this deposit is located at the downstream end of a recirculation zone. Higher exposures of sediment deposited during 1983 show that at least a part of the deposit was created by upstream-directed flows, which indicates that this recirculation zone was larger at higher discharges.

Upper-pool deposits may be subjected to erosive downstream-directed currents when the downstream constriction is overtopped. In August 1985, upper-p001 deposits at Cathedral Wash at river mile 2.3 and Six Mile Wash at river mile 5.7 were examined briefly to determine the effects of discharges of about $45,000 \mathrm{ft}^{3} / \mathrm{s}$. At each site, the upper-pool deposits had been eroded. 


\section{Channe]-Margin Deposits}

In some reaches, particularly where the channel is wide, sand deposits line the channel from a few hundred feet to nearly a mile. Channel-margin deposits are deposits that either lack the characteristic form of either separation or reattachment deposits, or whose location in relation to recirculation zones was not known. Few channel-margin deposits were investigated in detail; however, sedimentary structures within three such deposits (left bank beneath the U.S. Geological Survey cableway above the Little Colorado River confluence, Above Grapevine Rapid at river mile 81.1, and Pumpkin Springs at river mile 212) indicate that the deposits were formed by recirculating currents. Typically, these deposits mantle bedrock or talus. At low discharges, bedrock or talus may exist between the deposit and the water's edge. At other locations, parts of the channel-margin deposit have the form of a reattachment deposit. At low discharge, these deposits are adjacent to the water's edge.

\section{Distribution of Deposits}

Alluvial deposits large enough for use as campsites are most numerous between river miles 45 and 75,115 and 140 (fig. 25), and 160 and 225. These areas are within Lower Marble Canyon, Furnace Flats, Aisles, Middle Granite Gorge, and the Lower Canyon. These reaches include al1 those designated as wide (table 2) except the Permian Section. Availability of campsites in the Permian Section is limited by dense tamarisk tree groves and not by small alluvial sand deposits. Although the Aisles and Middle Granite Gorge reaches are designated narrow, there is great variability in channel width in these reaches, and campsites are located in parts of the reaches with wide channels or large expansions. Measurements of the area of major alluvial sand deposits in seven reaches show that average deposit size is also largest in the widest reaches (table 7). At a discharge of $5,600 \mathrm{ft}^{3} / \mathrm{s}$, average campsite size was $60,000 \mathrm{ft}^{2}$ in Lower Marble Canyon but 8,200 $\mathrm{ft}^{2}$ in the Muav Gorge. The smallest campsites are associated with reaches where channel-margin deposits are the main type (table 2). The largest campsites in Lower Marble Canyon are large reattachment deposits exposed at low discharge. Channel-margin and separation deposits are large in this reach as well.

Campsites noted on figure 25 are those inventoried by $\mathrm{Brian}$ and Thomas (1984) and are listed in Appendix A. The type of each deposit was determined by locating campsites on aerial photographs and comparing their form with the characteristic shapes of different types of deposits as described in this section. Observations of surface-current patterns at these sites aided in classifying some sites.

The number of separation deposits ranges between 0.2 and 1.0 deposits per mile throughout most of the river (table 2). The number of separation deposits used as campsites does not increase in wide reaches al though total number of campsites increases (fig. 25). Average area of major separation deposits is greater in wide reaches and varies in seven reaches between 14,500 and $57,000 \mathrm{ft}^{2}$. As described above, local topography of debris fans is the most important determinant in the 

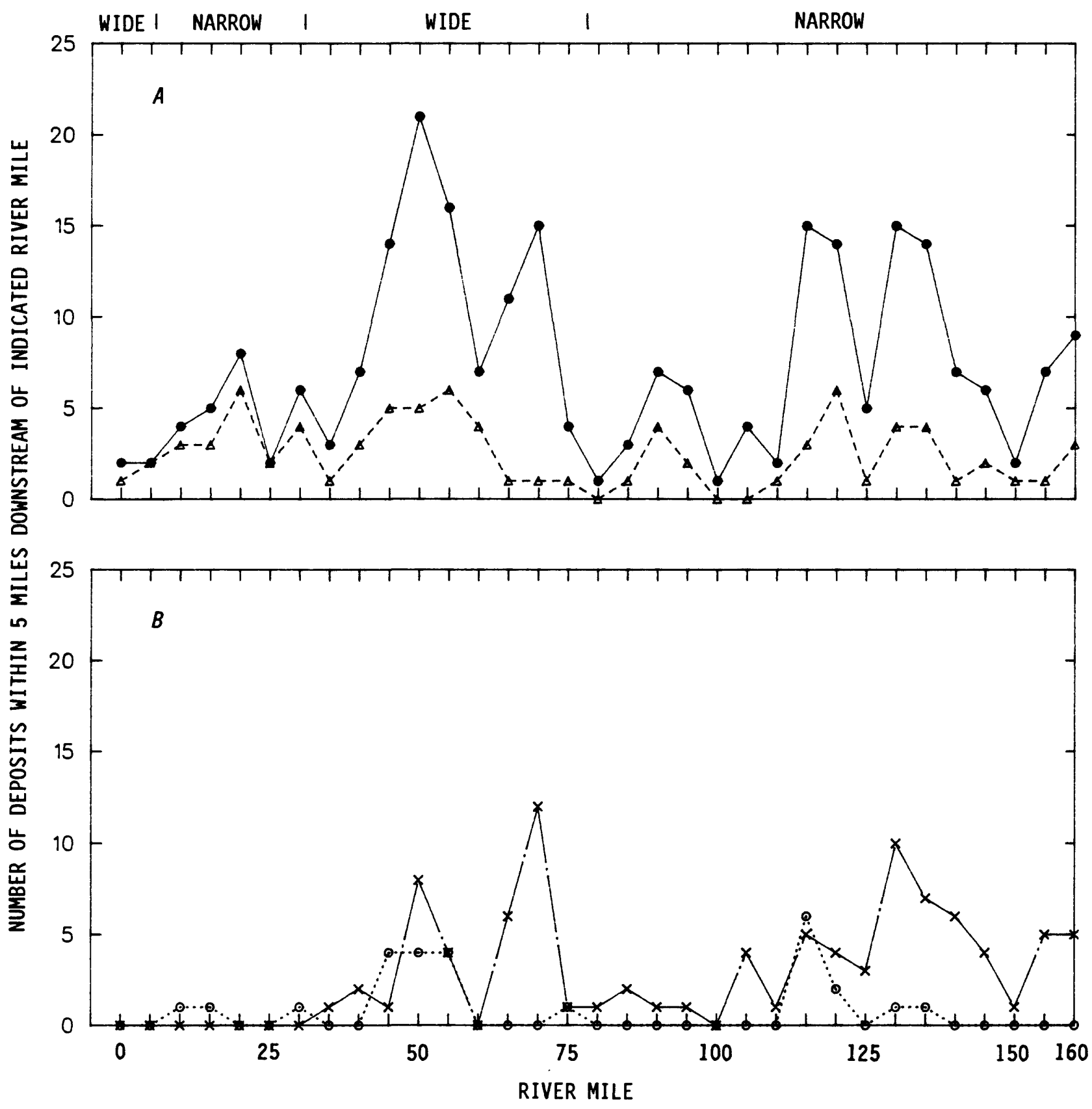

EXPLANATION

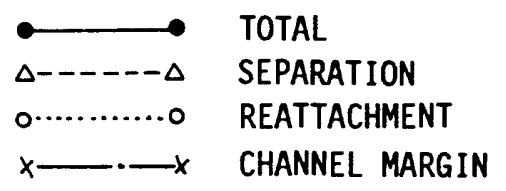

Figure 25.--Variation with river mile in number of alluvial deposits identified in 1983 (Brian and Thomas, 1984) as campsites. A, Total number of deposits and number of separation deposits. $B$, Number of reattachment deposits and channel-margin deposits between Lees Ferry and National Rapid. 
Table 7.--Areas of alluvial sand deposits at low discharge in selected reaches, October 1984

[All deposit values are in thousands of square feet]

\begin{tabular}{|c|c|c|c|c|c|c|c|c|c|c|c|c|c|c|}
\hline \multirow{3}{*}{$\begin{array}{c}\text { Reach } \\
\text { segment }\end{array}$} & \multirow{3}{*}{$\begin{array}{l}\text { Descrip- } \\
\text { tion of } \\
\text { reach } \\
\text { width }\end{array}$} & \multirow{2}{*}{\multicolumn{3}{|c|}{ All deposit typ }} & \multicolumn{8}{|c|}{ Area by type of deposit } & \multirow{2}{*}{\multicolumn{2}{|c|}{ Upper pool }} \\
\hline & & & & & \multicolumn{2}{|c|}{ Separation } & \multicolumn{2}{|c|}{ Reattachment } & \multicolumn{2}{|c|}{ Chamel margin } & \multicolumn{2}{|c|}{ Point bar } & & \\
\hline & & Total & Average & $\begin{array}{l}\text { per } \\
\text { mile }\end{array}$ & Total & Average & Total & Average & Total & Average & Total & Average & Total & Average \\
\hline $0-11.3$ & Wide & 410 & 51 & 36 & 230 & 57 & 93 & 31 & $\mathbf{0}$ & 0 & 92 & 92 & 0 & 0 \\
\hline $11.4-22.5$ & Narrow & 510 & 23 & 46 & 390 & 30 & 96 & 16 & 0 & 0 & 0 & 0 & 23 & 7.6 \\
\hline $22.6-35.9$ & Narrow & 540 & 25 & 41 & 290 & 21 & 190 & 47 & 0 & 0 & 0 & 0 & 54 & 18 \\
\hline $40.9-61.5$ & Wide & 4,700 & 60 & 180 & 1,200 & 49 & 1,900 & 87 & 1,300 & 73 & 37 & 37 & 270 & 21 \\
\hline $117.9-125.5$ & Narrow & 920 & 25 & 120 & 130 & 26 & 350 & 35 & 330 & 22 & 0 & 0 & 0 & 0 \\
\hline $125.6-139.9$ & Narrow & 900 & 22 & 63 & 240 & 17 & 140 & 34 & 410 & 20 & 0 & 0 & 97 & 32 \\
\hline $140-159.9$ & Narrow & 240 & 8.2 & 12 & 100 & 14.5 & 2.3 & 2.3 & 130 & 7.5 & 0 & 0 & 5.7 & 5.7 \\
\hline
\end{tabular}

occurrence of separation deposits. These deposits form wherever local site conditions permit, regardless of reach characteristics.

Channe 1-margin deposits are common in Lower Marble Canyon, Furnace Flats, and the Muav Gorge. At low discharges, these deposits have an average area of 73,000 $\mathrm{ft}^{2}$ in Lower Marble Canyon but only 7,500 $\mathrm{ft}^{2}$ in the Muav Gorge (table 7). The largest channel-margin deposit in the Muav Gorge is 23,000 $\mathrm{ft}^{2}$ (river mile 140.2). Campsites in Furnace Flats are similar in size to those of Lower Marble Canyon. Large campsites are typically associated with reattachment deposits and may be formed by similar processes. In Muav Gorge, channel-margin deposits typically mantle talus or bedrock in small reentrants. Reattachment deposits large enough to be used as campsites are numerous only between river miles 45-60 and 115-125.

\section{AGGRADATION AND DEGRADATION AT EIGHTEEN MILE WASH, 1965-86}

Sufficient data are available at some sites to permit development of a history of aggradation and degradation from 1965 to 1986 . The interpretation of data in the following section is illustrative of the interpretation of changes at other sites summarized in the section entitled "Aggradation and Degradation of Alluvial Sand Deposits, 1965-86."

\section{Hydrautic Conditions}

A small separation deposit mantles the downstream part of a low debris fan at the mouth of Eighteen Mile Wash about 18.1 river miles downstream from Lees Ferry (fig. 11). About $15,000 \mathrm{ft}^{2}$ of sand was 
exposed at $5,600 \mathrm{ft} 3 / \mathrm{s}$ and covered about 30 percent of the Eighteen Mile Wash debris fan in October 1984. Boulders exposed along the edge of water at the base of much of the sand deposit at $2,500 \mathrm{ft}^{3} / \mathrm{s}$ in October 1985 demonstrate that the sand deposit mantles the debris fan.

The Colorado River flows through a riffle of only slightly steepened water slope as it flows around the debris fan. A slope of 0.002 to 0.003 over a 600 - to 700 -foot reach exists at discharges between 4,000 and $45,000 \mathrm{ft}^{3} / \mathrm{s}$. The reach has a total elevation drop of about $3 \mathrm{ft}$ or about one-fifth the drop of major Grand Canyon rapids. A large, deep recirculation zone exists on the left side of the channel immediately below the riffle. Bathymetric surveys at a discharge of about $30,000 \mathrm{ft}^{3} / \mathrm{s}$ indicated average water depths of $20 \mathrm{ft}$ and a maximum depth of $37 \mathrm{ft}$ in this zone. The deepest part of the nearby main channel is about $50 \mathrm{ft}$. The recirculation zone exists at all discharges between at least 2,500 and $45,000 \mathrm{ft}^{3} / \mathrm{s}$ and extends in length by 35 percent as discharges increase from 3,000 to $45,000 \mathrm{ft}^{3} / \mathrm{s}$ (fig. 6). Over this discharge range, the separation point is located on the downstream margin of the exposed boulder deposit and migrates downstream along the slope of the separation deposit as the discharges decrease below about $25,000 \mathrm{ft}^{3} / \mathrm{s}$ (fig. 11). The location of the upstream part of the primary-eddy return current changes little with discharge.

Stage changes are significant in this reach where channel widthdepth ratio is less than 10 . Between 5,000 and $45,000 \mathrm{ft}^{3} / \mathrm{s}$, stage rises $20 \mathrm{ft}$; within the normal fluctuating flow range of 5,000 to $30,000 \mathrm{ft}^{3} / \mathrm{s}$, stage changes are about $14 \mathrm{ft}$. At the highest observed discharges $\left(45,000 \mathrm{ft}^{3} / \mathrm{s}\right)$, most of the Eighteen Mile Wash fan and the entire sand bar are submerged (fig. 12B). On May 22, 1985, at a discharge of $45,000 \mathrm{ft}^{3} / \mathrm{s}$, the entire deposit was submerged by a low-velocity area, as described in the previous section. Current directions and bed-form migration at this discharge show that flow and sediment transport over the deposit was upstream. A channel existed upstream from the slipface where flow was directed toward the main current.

In August 1985 , conditions in the recirculation zone were observed at a discharge of about $28,000 \mathrm{ft}^{3} / \mathrm{s}$. The primary eddy was in approximately the same location; however, the entire surface of the deposit was exposed (fig. 12C). A small secondary eddy existed offshore from the downstream part of the deposit, and the mean velocities in this eddy did not exceed $1.2 \mathrm{ft} / \mathrm{s}$. Elsewhere along the deposit face, measured mean velocities did not exceed $1 \mathrm{ft} / \mathrm{s}$.

\section{Topographic Changes of the Separation Deposit}

The first available areal photograph showing topography of the deposit (fig. 26A) was taken May 14, 1965, at a daily mean discharge of about $26,700 \mathrm{ft}^{3} / \mathrm{s}$ and at a stage of about $91 \mathrm{ft}$. Elevation of stage was estimated by comparison of shorelines of the 1965 photograph with mapping of the shoreline in 1985 at various discharges. The shoreline along bedrock, talus, and the debris fan are very similar to the shoreline mapped in August 1985 at a discharge of about $28,000 \mathrm{ft}^{3} / \mathrm{s}$. River stage in the photograph of 1965 was estimated by referring to the surveyed 
elevation of the water surface in August 1985. Sand exposed in the photograph of 1965 exceeds the elevation of the observed water surface and thus must be higher than $91 \mathrm{ft}$ (fig. 27).

In 1965, the deposit had an L-shape and bedrock was exposed between the deposit and water's edge at the downstream end. The part protruding toward the opposite bank may actually have been smaller than in 1985. A low area between the exposed debris fan and the sand deposit is believed to be a remnant return-flow channel.

Better topographic control exists for the data of the mid-1970's. An aerial photograph was taken on June 16, 1973, at a discharge of about $4,500 \mathrm{ft}^{3} / \mathrm{s}$ (fig. 26B). River stage was estimated to be about $78 \mathrm{ft}$. In the same year, photographs were taken from nearby cliffs accessible from the river, and on July 7, 1975, Howard (1975) surveyed the topography of the deposit along two profiles.

A topographic map of the deposit as it existed in 1975 was constructed from these data (fig. 12A). The exposed fan and separation deposit in a photograph taken October 21, 1984, at a discharge of $5,600 \mathrm{ft}^{3} / \mathrm{s}$ (fig. 26C) are similar to the plan-view pattern of these deposits in 1973 and 1975. Data from the topographic survey of 1975, however, show that the shoreward part of the deposit was about $87 \mathrm{ft}$ in elevation and that the sand surface rose to about $98 \mathrm{ft}$ in elevation near the bedrock wall (fig. 27). A substantial part of this deposit, therefore, degraded at least $4.5 \mathrm{ft}$ between 1965 and 1973 . If the as sumption is made that no change occurred in the estimated stagedischarge relation, this surface would be just overtopped by a discharge of $18,000 \mathrm{ft}^{3} / \mathrm{s}$. Between 1965 and 1973, maximum powerplant flows were about 24,000 ft3/s (Howard, 1975) or a stage of $89.5 \mathrm{ft}$, which is sufficient to inundate the main surface about $2.5 \mathrm{ft}$. The air and ground photographs of the mid-1970's also document tamarisk trees at approximately a stage associated with flows of $24,000 \mathrm{ft}^{3} / \mathrm{s}$. The deposit was armored on all sides in 1973 (fig. 26B).

Following recession of the flood of 1983 , a resurvey of the deposit on September 13, 1983, (Beus and others, 1985) showed aggradation of about $6.5 \mathrm{ft}$ on the stream side and about $4 \mathrm{ft}$ of erosion of the $h i g h$ sand bank that had existed along the bedrock cliff (fig. 27). The elevation of the crest of the deposit was about $94 \mathrm{ft}$. Comparison of the discharge record of 1983 and the stage-discharge relation shows that the lowest discharge immediately before exposure of the deposit on August 10 was about $36,000 \mathrm{ft}^{3} / \mathrm{s}$ (stage, $94 \mathrm{ft}$ ). This discharge had existed for about 8 days (fig. 28A). At that time, the separation deposit was within $1 \mathrm{ft}$ of this stage. The river had been receding from its peak discharge of $97,300 \mathrm{ft}^{3} / \mathrm{s}$, which had occurred on June $29,1983$.

A survey of the deposit on August 1, 1984 (Beus and others, 1985) (fig. 27), documented further aggradation of about $2 \mathrm{ft}$ on the main surface to an elevation of about $96 \mathrm{ft}$. On the basis of the hydrograph of that year (fig. 9) and the local stage-discharge relation, the only flows that could have caused this aggradation were the high releases of May to July 1984 when daily mean discharge was about 45,000 $\mathrm{ft}^{3} / \mathrm{s}$ and stage was about $98 \mathrm{ft}$ (fig. 28B). The bar aggraded to within $2 \mathrm{ft}$ of the water surface. Although data are not available to more precisely date this 
aggradation, data collected in 1985 provide an insight into deposit response during high flows.

Resurvey of the deposit on May 22, 1985, showed that the deposit was much smaller in size than in 1984 (figs. 12B and 27). The river had been flowing between 38,000 and $46,000 \mathrm{ft}^{3} / \mathrm{s}$ since May 17, 1985 (fig. 9). Aside from a 6-day period when daily mean discharge was about $30,000 \mathrm{ft}^{3} / \mathrm{s}$, discharges exceeding $40,000 \mathrm{ft}^{3} / \mathrm{s}$ cont inued unt il June 25 (fig. 28C). On the basis of the stage-discharge relation, the deposit would have been exposed on June 28 when discharges receded below $40,000 \mathrm{ft}^{3} / \mathrm{s}$. Resurveying on August 2, 1985 (figs. $12 \mathrm{C}$ and 27), showed that at least 2,900 $\mathrm{ft}^{3}$ of sand, and more likely 13,000 $\mathrm{ft}^{3}$, had been deposited since the survey of May 22 despite the fact that the crest of the deposit had not increased in elevation. The latter estimate is based on projection of surveyed slopes for unsurveyed areas by assuming the angle of repose and on extension to known debris-fan deposits at depth.

Analysis of sedimentary structures within this deposit showed that aggradation generally was consistent with directions of the current as measured in May. Steep planar foreset cross beds document the upstream migration of the deposit (fig. 13); however, the deposit al so aggraded on its downstream-facing slope (fig. 27).

Comparison of the surveys of August 1984 and May 1985, therefore, suggests that degradation is associated with the initial rise of discharge. This interpretation is reasonable despite the fact that from August 11 until August 15, 1984, spillway tests were run at Glen Canyon Dam and instantaneous peak discharges reached $56,600 \mathrm{ft}^{3} / \mathrm{s}$ (fig. 9). Daily mean discharges exceeded $40,000 \mathrm{ft}^{3} / \mathrm{s}$ on 3 days. The extent of aggradation or degradation on these days of high flow is not precisely known. However, the high flows likely resulted in only minor erosion at this site because aerial photography for 0ctober 21, 1984, (fig. 26C) shows a deposit similar to that mapped in 1984 .

The exposed deposit surveyed on August 2, 1985, was slightly smaller than at the time of the survey of August 1984 (fig. 27). The deposit may have been larger immediately after recession of the flows of 1984 than the same deposit immediately after recession of the flows of 1985; however, erosion may have occurred in 1985 between the day of initial exposure, June 25, and the date of the survey, August 2. Thus, despite substantial scour of the deposit during the 1985 flood, the deposit likely never aggraded higher than 1 to $2 \mathrm{ft}$ below the water surface in 1984 or 1985 . Each year, the deposit was re-established in approximately its same shape. In each of these years, the flow receded in a similar pattern. In 1983, aggradation was well documented, but the resulting deposit was of lower elevation. The deposit was reworked by flows of $36,000 \mathrm{ft}^{3} / \mathrm{s}$ during flow recession. At that discharge, the deposit would also have been about $1 \mathrm{ft}$ below water surface. The level to which the deposit typically restablizes after initial scour may be a direct function of the rate of decrease in discharge during flow recession.

Net aggradation between 1983 and 1984 probably does not reflect greater sediment transport during the latter event; al though sediment-transport data are not available to document main-channel 

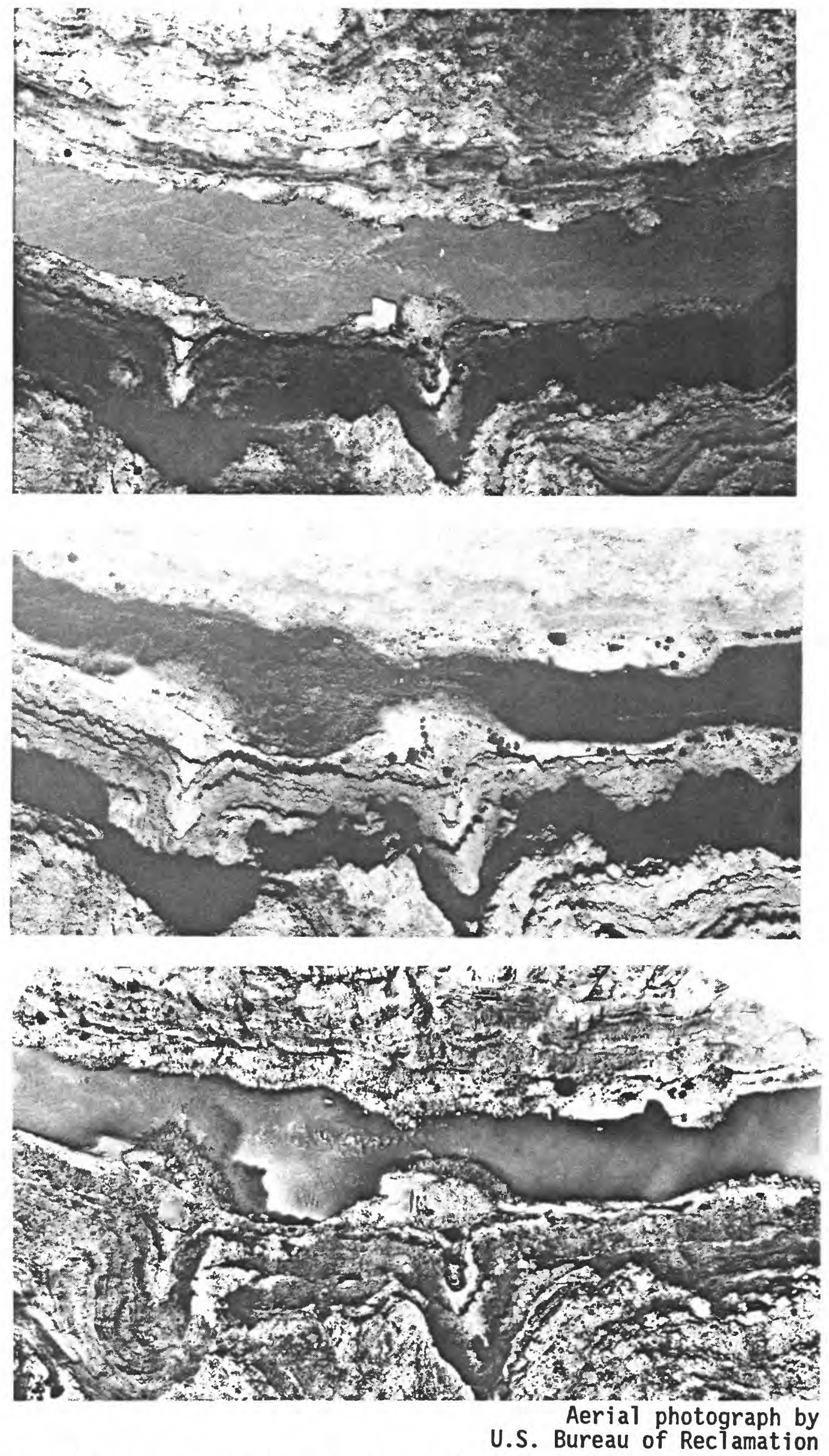

Figure 26.--Colorado River near Eighteen Mile Wash. A, On May 14, 1965, discharge 26,700 cubic feet per second. $B$, On June 16, 1973, discharge 4,500 cubic feet per second. C, On October 21, 1984, discharge 5,600 cubic feet per second. Surficial geology shown in figure 11. 


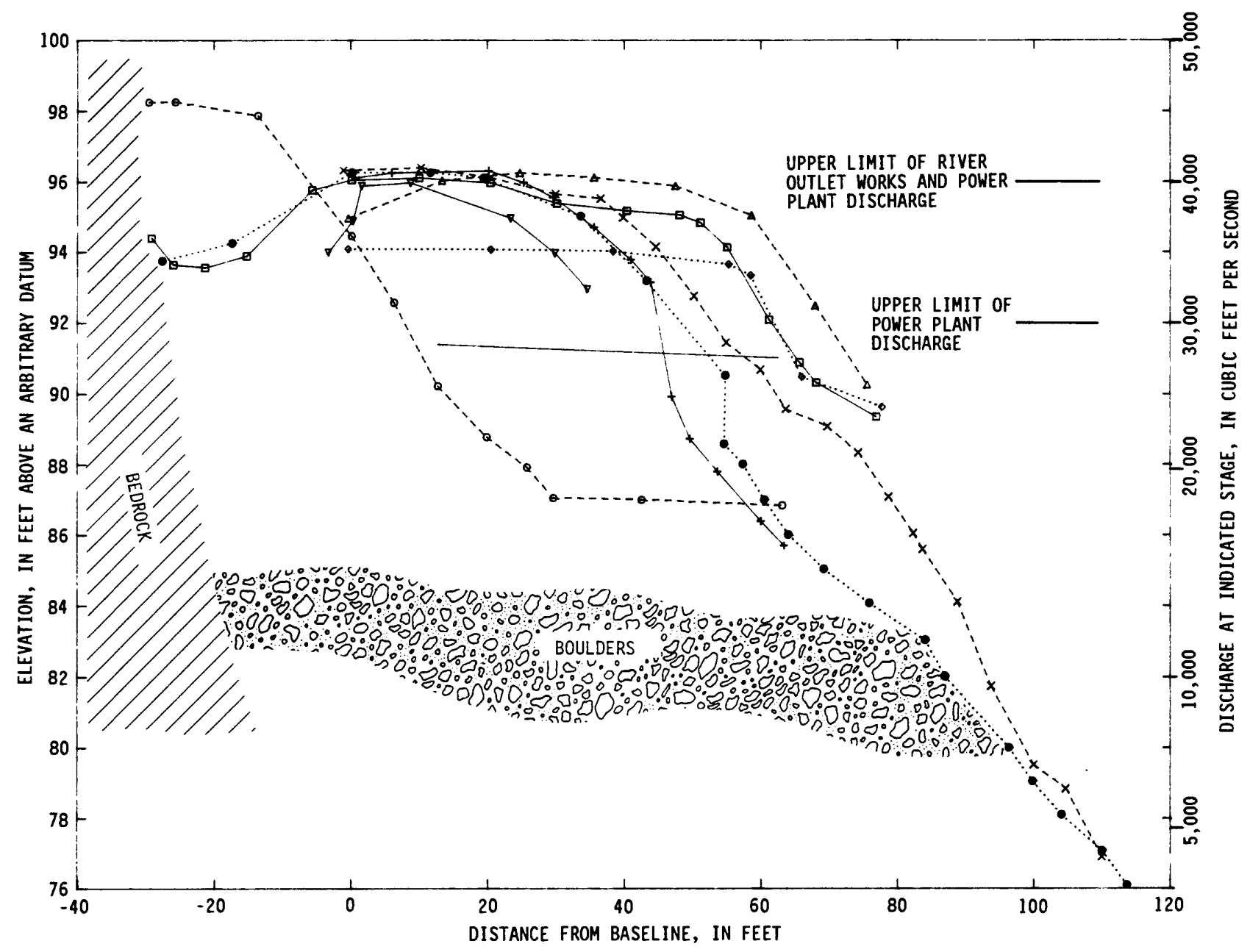

EXPLANATION

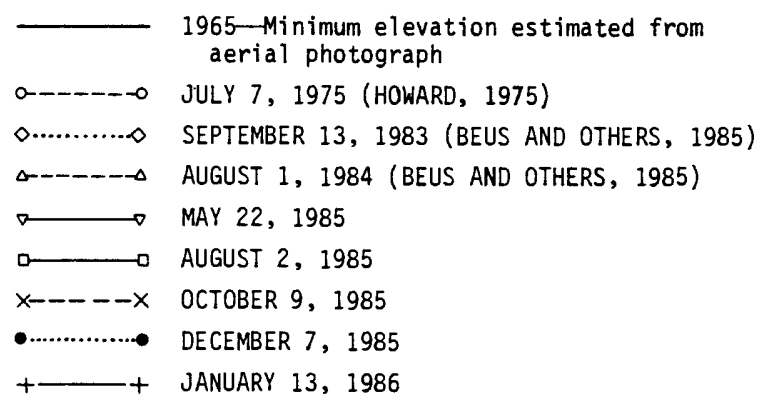

Figure 27.--Topography along profile 2 at Eighteen Mile Wash. 

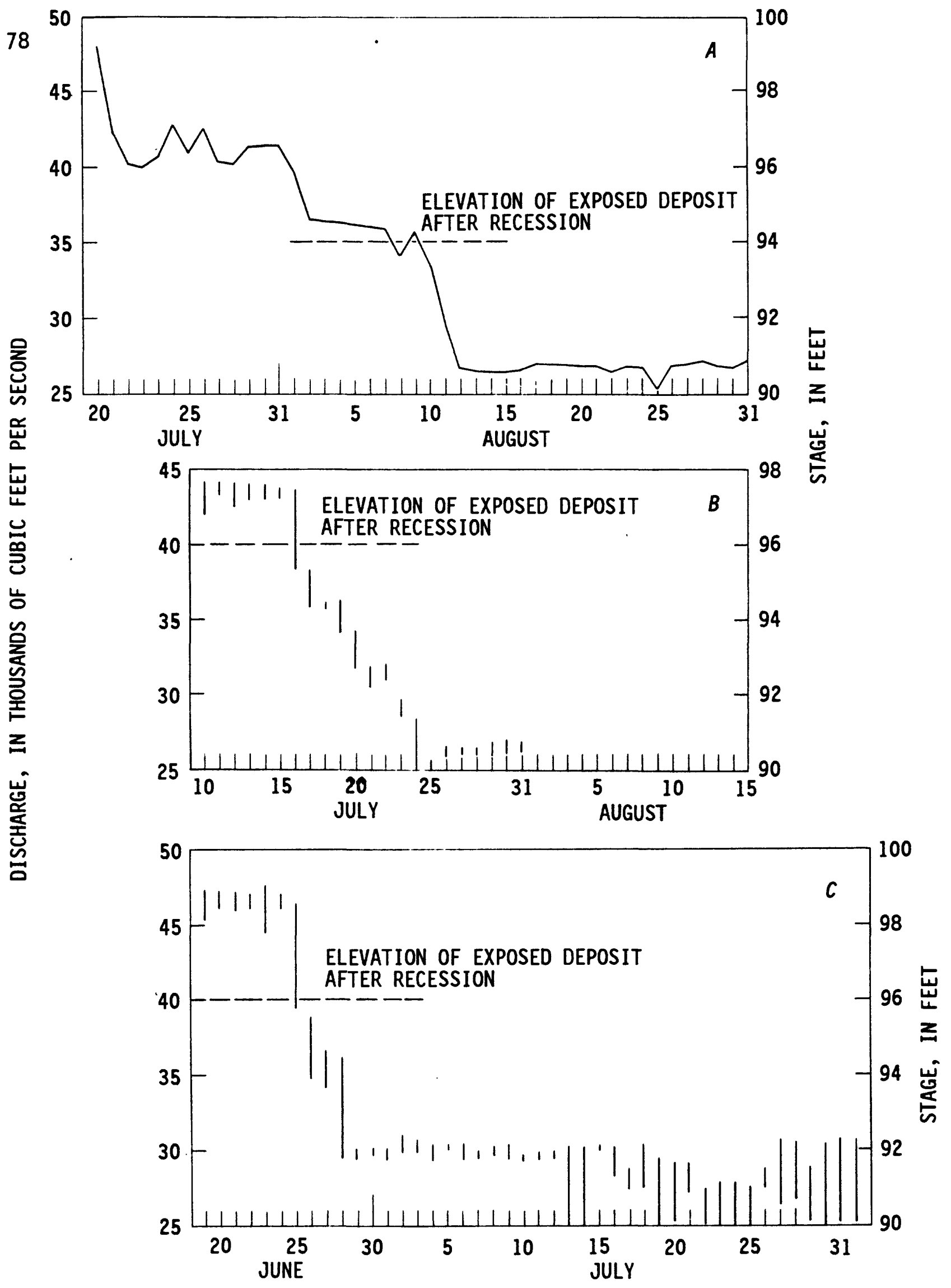

Figure 28.--Discharge and stage during recession of high flows at Eighteen Mile Wash. A, In 1983. B, In 1984. C, In 1985. 
conditions. Local geometry of the Eighteen Mile Wash debris fan is such that between 36,000 and $28,000 \mathrm{ft}^{3} / \mathrm{s}$, flow is diverted away from the separation deposit. Therefore, in 1984, separation-deposit elevation was related to the $45,000 \mathrm{ft}^{3} / \mathrm{s}$ discharge, but in 1983 the deposit continued to be reworked until discharge dropped from 36,000 to $25,000 \mathrm{ft}^{3} / \mathrm{s}$. In each case, equilibrium conditions limit aggradation to about 1-2 ft below the water surface in the low-velocity area.

After October 1, 1985, discharge never exceeded $20,000 \mathrm{ft}^{3} / \mathrm{s}$ or a stage of $88 \mathrm{ft}$ during this study. Stage was sometimes as low as $76 \mathrm{ft}$. During this time, the downstream part of the deposit eroded rapidly (fig. 27). In January 1986 after 3 months of fluctuating flow, a 3-foot-high cutbank still existed. It had retreated horizontally 15 to $25 \mathrm{ft}$ between August and early January. All erosion between October and January can be attributed to strongly fluctuating flow, and at least part of the erosion from August to october probably is associated with the first few days of fluctuating flows before the survey in october. The base of the cutbank developed at the approximate elevation of the highest discharge of the fluctuations from October to mid-January. Most of the retreat, therefore, was caused by bank collapse from saturation and undermining of the well-sorted fine sands. Nearshore velocities did not exceed about $1 \mathrm{ft} / \mathrm{s}$. Waves were not present at this site. Degradation of the slope below the cutbank, subject to daily discharge fluctuations, was at a lower rate than degradation of the high exposed cutbank.

Aggradation caused by the high releases of 1983 more than compensated for the erosion that had occurred between 1965 and 1975 (fig. 29). Data are not available for 1975-83. Howard and Dol an (1981), however, observed that alluvial deposits had stabilized by the late 1970's. The alternating pattern of aggradation and degradation between June 1983 and May 1985 related to annual high flows is estimated on the basis of measured erosion and deposition during high releases in 1985 described above. The amount of degradation between August 1985 and January 1986 is similar to the net change between 1965 and 1975 . The rate of change measured in 1985 and 1986 far exceeds the average rate for the earlier period. The existence of a cutbank at the end of the special fluctuating-flow period suggests that erosion would have continued if strong fluctuations had continued beyond mid-January. Therefore, at this site, newly aggraded deposits formed and reworked by flows in 1983, 1984, and 1985 were unstable under strongly fluctuating discharge. Upslope projection of the lower part of the January 1986 profile gives a likely minimum erosion that would have occurred if fluctuations had continued. A likely maximum extent of erosion would be degradation to the profile surveyed in 1975.

\section{BATHYMETRIC SURVEYS}

Short-term topographic changes in recirculation zones were obtained by repetitive bathymetric surveys. The time of day and discharge during each survey are listed on table 1. Because these surveys are primarily of the lower elevation parts of recirculation zones, surveyed areas are not used as campsites; however, they are the major sand storage parts of recirculation zones. 
80

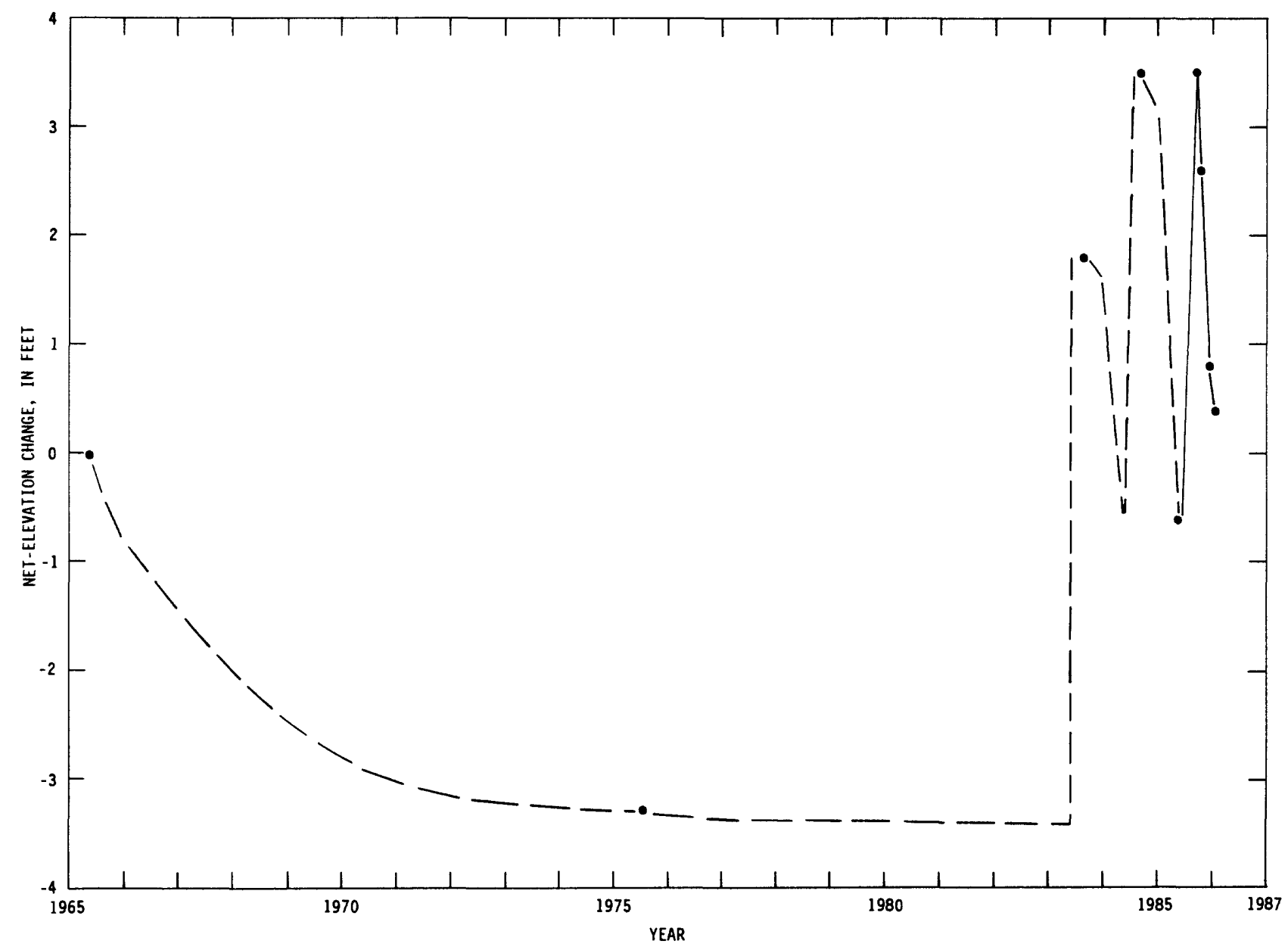

Figure 29.--Net-elevation change of separation deposit at Eighteen Mile Wash, 1965 to January 1986, along profile 2. 
The recirculation zone at river mile 120.1 just below Blacktail Rapid was surveyed with 710 data points in September 1985 and January 1986 (table 1). The zone is nearly circular in plan view (fig. 21). The primary eddy covers most of the area, al though small secondary eddies were observed along the banks during both surveys. The zone has an excellent geometry for bathymetric surveying. Uncertainty in position is less than $5 \mathrm{ft}$ over most of the area but reaches almost. $18 \mathrm{ft}$ at the extreme downstream end of the surveyed area.

The bathymetric map of September (fig. 22A) illustrates the characteristic shape of the sand deposit within the recirculation zone. The sand deposit had a relatively level upper surface and a steep slope into the main channel. A reattachment deposit and primary-eddy return-current channel were present on the upper surface. A small separation deposit was present at the upper end of the zone upstream from the return-current channel but was a minor part of the total zone. A bathymetric map based on the January survey shows that considerable changes had taken place in these features (fig. 22B). Volume changes estimated for this recirculation zone by comparison of bathymetric maps represent change in volume of sand below the stage corresponding to the discharge at the time of the surveys. Discharge was strongly fluctuating for most of the period between the surveys, but fluctuated less strongly $\left(15,000-21,000 \mathrm{ft}^{3} / \mathrm{s}\right)$ for the 8 days before the January survey. Therefore, the observed changes may not be solely related to the effects of strongly fluctuating flow.

The return-current channel was shallower and less well developed during both surveys at this site than in other surveyed recirculation zones and was shallower and less distinct in January than in September. The elevation of much of the reattachment deposit was 2-4 ft lower in January than in September, and the slope had flattened and moved toward the channel thalweg. Profiles drawn from bathymetric maps illustrate and quantify these changes (fig. 23). Profiles 1, 4, and 8 show how changes varied over the zone. The extreme downstream end of the zone (profile 1, fig. 23) and most of the crest of the reattachment deposit degraded, whereas the slope into the main channel aggraded (profile 4, fig. 23). At the upstream end, aggradation on the downstream side of the return-current channel caused the channel to shift toward the bank and to become shallower (profile 8, fig. 23). On all profiles, the point of zero change is roughly coincident with the break in slope between the upper surface of the sand deposit and the slope into the main channel. In January the sand deposit sloped uniformly and gently toward the main channel and did not have a distinct reattachment-deposit crest and primary-eddy return-current channel.

The amount of change between the two surveys was estimated by measuring the area between profile lines for successive surveys (fig. 23, table 8). Along all profiles, degradation totaled $1,100 \mathrm{ft}^{2}$ and aggradation totaled $3,010 \mathrm{ft}^{2}$. Net change was $1,910 \mathrm{ft}^{2}$ of aggradation. Vertical changes along profiles was estimated by dividing the area of change by the length of the profile. An average of 1-2 ft of degradation occurred over the upper surface of the deposit, and aggradation of 3-6 ft occurred along the slope into the main channel. 
Table 8.-- - Summary of changes between bathymetric surveys

[Aggradation and degradation were computed as the difference in area between profile lines for successive surveys. Average vertical change was computed by dividing the area of net vertical change along profile lines by the length of the line. Dashes, no data]

\begin{tabular}{|c|c|c|c|c|c|c|c|c|c|}
\hline \multirow[b]{3}{*}{ Profile } & \multicolumn{4}{|c|}{ April-September 1985} & \multicolumn{5}{|c|}{ Septenber 1985-January 1986} \\
\hline & \multirow[b]{2}{*}{$\begin{array}{l}\text { Aggra- } \\
\text { dation, } \\
\text { in } \\
\text { square } \\
\text { feet }\end{array}$} & \multirow[b]{2}{*}{$\begin{array}{l}\text { Degra- } \\
\text { dation, } \\
\text { in } \\
\text { square } \\
\text { feet }\end{array}$} & \multirow[b]{2}{*}{$\begin{array}{l}\text { Net } \\
\text { change } \\
\text { in } \\
\text { area, } \\
\text { in } \\
\text { square } \\
\text { feet }\end{array}$} & \multirow{2}{*}{$\begin{array}{l}\text { Average } \\
\text { vertical } \\
\text { change } \\
\text { in upper } \\
\text { surface } \\
\text { of deposit, } \\
\text { in feet }\end{array}$} & \multirow[b]{2}{*}{$\begin{array}{l}\text { Aggra- } \\
\text { dation, } \\
\text { in } \\
\text { square } \\
\text { feet }\end{array}$} & \multirow[b]{2}{*}{$\begin{array}{l}\text { Degra- } \\
\text { dation, } \\
\text { in } \\
\text { square } \\
\text { feet }\end{array}$} & \multirow[b]{2}{*}{$\begin{array}{l}\text { Net } \\
\text { change } \\
\text { in } \\
\text { area, } \\
\text { in } \\
\text { square } \\
\text { feet }\end{array}$} & \multicolumn{2}{|c|}{ Average vertical change } \\
\hline & & & & & & & & $\begin{array}{l}\text { Upper } \\
\text { surface } \\
\text { of } \\
\text { deposit, } \\
\text { in feet }\end{array}$ & $\begin{array}{l}\text { Slope } \\
\text { into } \\
\text { main } \\
\text { channel, } \\
\text { in feet }\end{array}$ \\
\hline
\end{tabular}

Eminence Break Camp

\begin{tabular}{|c|c|c|c|c|c|c|c|c|c|}
\hline $\begin{array}{r}1 \\
2 \\
3 \\
4 \\
5 \\
6 \\
7 \\
8 \\
9 \\
10 \\
11 \\
12 \\
13\end{array}$ & $\begin{array}{r}164 \\
41 \\
197 \\
37 \\
4 \\
142 \\
62 \\
0 \\
0 \\
0 \\
0 \\
14 \\
15\end{array}$ & $\begin{array}{r}0 \\
2 \\
0 \\
418 \\
386 \\
401 \\
202 \\
246 \\
421 \\
282 \\
132 \\
270 \\
305\end{array}$ & $\begin{array}{r}164 \\
+39 \\
+197 \\
-381 \\
-382 \\
-259 \\
-140 \\
-246 \\
-421 \\
-282 \\
-132 \\
-256 \\
-300\end{array}$ & $\begin{array}{l}+2.6 \\
+0.6 \\
-1.7 \\
-2.9 \\
-3.1 \\
-1.6 \\
-0.9 \\
-1.6 \\
-2.6 \\
-1.8 \\
-1.1 \\
-1.9 \\
-4.2\end{array}$ & $\begin{array}{r}0 \\
0 \\
11 \\
142 \\
100 \\
96 \\
99 \\
113 \\
102 \\
0 \\
0 \\
54 \\
169\end{array}$ & $\begin{array}{r}341 \\
235 \\
260 \\
67 \\
45 \\
321 \\
101 \\
122 \\
112 \\
276 \\
78 \\
68 \\
6\end{array}$ & $\begin{array}{r}-341 \\
-235 \\
-249 \\
+75 \\
+55 \\
-225 \\
-2 \\
-9 \\
-10 \\
-276 \\
-78 \\
-14 \\
+163\end{array}$ & $\begin{array}{r}-5.4 \\
-3.5 \\
-2.2 \\
+0.6 \\
+0.4 \\
-1.4 \\
0.0 \\
-0.1 \\
-0.1 \\
-1.7 \\
-0.7 \\
-0.1 \\
+2.3\end{array}$ & $\begin{array}{l}\ldots \ldots \\
\ldots \ldots \\
\ldots \ldots \\
\ldots \ldots \\
\ldots \ldots \\
\ldots \ldots \\
\ldots \ldots \\
\ldots \\
\ldots \\
\ldots \\
\ldots \\
\ldots \\
\ldots\end{array}$ \\
\hline
\end{tabular}

Lower Blacktail Rapid

\begin{tabular}{|c|c|c|c|c|c|c|c|c|c|}
\hline $\begin{array}{l}1 \\
2 \\
3 \\
4 \\
5 \\
6 \\
7 \\
8\end{array}$ & $\begin{array}{l}\ldots . . \\
\ldots \ldots \\
\ldots . . \\
\ldots \ldots \\
\ldots \ldots \\
\ldots \ldots \\
\ldots \ldots \\
\ldots\end{array}$ & 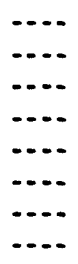 & $\begin{array}{l}\ldots \\
\ldots \\
\ldots \\
\ldots \\
\ldots \\
\ldots \\
\ldots \\
\ldots \\
\ldots\end{array}$ & $\begin{array}{l}\ldots \ldots \\
\ldots \ldots \\
\ldots . \\
\ldots \ldots \\
\ldots \ldots \\
\ldots \ldots \\
\ldots \ldots \\
\ldots\end{array}$ & $\begin{array}{r}0 \\
537 \\
444 \\
721 \\
574 \\
173 \\
428 \\
83\end{array}$ & $\begin{array}{r}186 \\
8 \\
105 \\
223 \\
220 \\
228 \\
125 \\
0\end{array}$ & $\begin{array}{r}-186 \\
+529 \\
+339 \\
+498 \\
+354 \\
-55 \\
+302 \\
+83\end{array}$ & $\begin{array}{r}-1.6 \\
0.0 \\
-0.8 \\
-1.3 \\
-1.3 \\
-1.4 \\
-0.2 \\
+0.7\end{array}$ & $\begin{array}{l}+ \\
+3.8 \\
+4.6 \\
+5.9 \\
+4.7 \\
+2.8 \\
+3.6 \\
+\ldots\end{array}$ \\
\hline \multicolumn{10}{|c|}{ National Rapid } \\
\hline $\begin{array}{l}1 \\
2 \\
3 \\
4 \\
5 \\
6\end{array}$ & $\begin{array}{r}268 \\
230 \\
189 \\
103 \\
13 \\
76\end{array}$ & $\begin{array}{r}37 \\
10 \\
36 \\
69 \\
9 \\
0\end{array}$ & $\begin{array}{r}+231 \\
+230 \\
+153 \\
+34 \\
+4 \\
+76\end{array}$ & $\begin{array}{c}+1.4 \\
+1.6 \\
+0.9 \\
+0.3 \\
0 \\
+1.1\end{array}$ & $\begin{array}{r}116 \\
0 \\
66 \\
0 \\
16 \\
0\end{array}$ & $\begin{array}{r}414 \\
219 \\
95 \\
122 \\
29 \\
66\end{array}$ & $\begin{array}{r}-298 \\
-219 \\
-29 \\
-122 \\
-13 \\
-66\end{array}$ & $\begin{array}{l}-1.8 \\
-1.6 \\
-0.2 \\
-1.2 \\
-0.2 \\
-0.9\end{array}$ & $\begin{array}{l}\ldots . \\
\ldots . \\
\ldots . \\
\ldots \\
\ldots\end{array}$ \\
\hline
\end{tabular}


Areas of change along profile lines were used to estimate volume of change over the mapped area by assuming that changes computed at profile lines took place over half the distance between a profile line and the adjacent line. For profiles 1 and 8 at the upstream and downstream ends of the area, only the area on the side of the profile line toward the recirculation zone was used in the computation. The net volume of change is $+122,000 \mathrm{ft}^{3}$.

Aggradation of the slope between recirculation zone and thalweg cannot be attributed solely to degradation of the upper surface. Estimates of total volume change on the upper surface and on the slope indicate that four to five times more sediment aggraded on the slope than degraded from the upper surface.

The recirculation zone at Eminence Break Camp, at river mile 44.2 , is almost twice as long as it is wide (fig. 14). Bathymetric maps were made from surveys in April 1985, September 1985, and January 1986 using 1,055, 753, and 984 data points, respectively (fig. 15). Only the area of the recirculation zone inundated by a discharge of about $20,000 \mathrm{ft}^{3} / \mathrm{s}$ was surveyed. Less than 5 percent of the reattachment deposit projects above the stage corresponding to $20,000 \mathrm{ft}^{3} / \mathrm{s}$. A large separation deposit mantles the upstream debris fan (fig. 14) and extends upslope above the area of bathymetric maps. The primary-eddy returncurrent channel, the reattachment deposit, and the slope into the main channel are similar to those at Blacktail Rapid. The return-current channel, however, is more clearly defined and deeper at this site than at Blacktail Rapid, and the reattachment-deposit crest is more distinct (fig. 18). Data are sparse over the slope into the main channel and uncertainty in position of the contours defining the slope is much larger than at Blacktail Rapid. Estimates of change on the slope, therefore, have not been made. The position uncertainty is lowest over the central part of the zone $(4.3 \mathrm{ft})$ and highest at the upper end $(14.5 \mathrm{ft})$.

Comparison of maps for April and September shows that most of the zone degraded considerably. This period includes 2 months of releases through river outlet works (fig. 9). The upper end of the zone shoreward from the return-current channel aggraded. The slope into the main channel appears to have aggraded, but the amount is unknown because of uncertainty in the contours. Between September and January (fig. 15) during fluctuating flow, the crest of the reattachment deposit aggraded, whereas most of the upper surface of the deposit degraded. Profiles illustrate these changes (fig. 16). Along profile 2, at the upstream end of the zone, little change took place between April and September, but degradation occurred along the profile between September and January. Deposition along the end of profile 7 nearest the bank caused the return-current channel to move toward the main channel between April and September (fig. 16). The crest of the reattachment deposit decreased in elevation and moved toward the main channel. The January profile shows that the reattachment deposit aggraded slightly between September and January but was still lower in elevation than in April. The deposit crest and return-current channel had returned to the positions of April. At the lower end of the recirculation zone, degradation occurred between April 
and September and aggradation occurred between September and January (profile 13, fig. 16). Like profile 7, profile 16 shows that the surface in January was still lower than that in April in spite of aggradation.

Changes in area along profile lines at Eminence Break Camp are summarized in table 8 . Because of uncertainty in the position of contours near the main channel, only areas of the upper-deposit surface were measured. Between April and September, total aggradation along profile lines was 1,670 $\mathrm{ft}^{2}$, total degradation was 3,070 $\mathrm{ft}^{2}$, and net change was $-2,400 \mathrm{ft}^{2}$. Average vertical changes along profile lines ranged from $+2.6 \mathrm{ft}$ to $-4.2 \mathrm{ft}$ from April to September and +2.3 to $-5.4 \mathrm{ft}$ from September to January (table 9 ). Between September and January, aggradation was $890 \mathrm{ft}^{2}$, degradation was 2,030 $\mathrm{ft}^{2}$, and net change was $-1,140 \mathrm{ft}^{2}$. The net change for April to January was $-3,540 \mathrm{ft}^{2}$. Estimated volume change was $-148,000 \mathrm{ft}^{3}$ from April to September, $-79,200 \mathrm{ft}^{3}$ from September to January, and $-227,000 \mathrm{ft}^{3}$ for the entire period.

The recirculation zone just below National Rapid (fig. 30) at river mile 166.6 is similar in shape to that at Eminence Break Camp. Data points for surveys in April 1985, September 1985, and January 1986, which number 768,432 , and 368 , respectively, are evenly distributed over the zone. Bottom configuration at National Rapid (fig. 31) is also similar to

Table 9.-- - Number of separation and reattachment deposits in recirculation zones between river miles 0 and 118,1973 and 1984

\begin{tabular}{|c|c|c|c|c|c|c|c|}
\hline \multirow{3}{*}{$\begin{array}{l}\text { Reach } \\
\text { segment }\end{array}$} & \multirow{3}{*}{$\begin{array}{l}\text { Total number } \\
\text { of recircula- } \\
\text { tion zones } \\
\text { surveyed }\end{array}$} & \multirow{3}{*}{$\begin{array}{l}\text { Width } \\
\text { of } \\
\text { reach }\end{array}$} & \multirow{3}{*}{$\begin{array}{l}\text { Bias } \\
\text { of } \\
\text { analy- } \\
\text { sis }\end{array}$} & \multicolumn{4}{|c|}{ Deposit type 1} \\
\hline & & & & \multicolumn{2}{|c|}{ Reattachment } & \multicolumn{2}{|c|}{ Separatior } \\
\hline & & & & 1973 & 1984 & 1973 & 1984 \\
\hline $0-11.3$ & 36 & Wide & Decrease & 31 & 28 & 18.5 & 19.5 \\
\hline $11.4-22.5$ & 40 & Narrow & Decrease & 27 & 20.5 & 26 & 26 \\
\hline $22.6-35.9$ & 60 & Narrow & No bias & 37.5 & 34 & 38.5 & 29.5 \\
\hline $40-61.5$ & 115 & Wide & Increase & 96.5 & 100.5 & 49.5 & 50 \\
\hline $61.6-77.4$ & 37 & Wide & Increase & 28 & 32 & 23.5 & 25 \\
\hline $77.5-117.8$ & 111 & Narrow & Increase & $\underline{78.5}$ & 68.5 & 28.5 & 27.5 \\
\hline Total & 399 & & & 298.5 & 283.5 & 184.5 & 187.5 \\
\hline
\end{tabular}
in stage. 
that at Eminence Break Camp with a well-defined return-current channel and reattachment-deposit crest. At this site, however, the reattachment-deposit crest is separated from the bank at the lower end of the recirculation zone by the return-current channel. A second recirculation zone was present downstream from the mapped area during all surveys, and the two zones may have joined at some discharges. Position uncertainty at this site varied from trip to trip because remote locations were different for each trip. In April and September, uncertainty was largest at the upper and lower ends of the zone (10-11 ft) and smallest over the central part $(4.3 \mathrm{ft})$. For the survey of January 1986, the uncertainty in position ranged from $4.3 \mathrm{ft}$ at the upper edge near the bank to $8 \mathrm{ft}$ at the edge toward the main channel near the center of the zone. A large separation deposit mantles the National Canyon debris fan. Most of this deposit is higher in elevation than the stage during bathymetric surveying. No part of the reattachment deposit exists above the stage at which bathymetric surveys were made.

The shape of the primary-eddy return-current channel and reattachment deposit was similar during all three surveys (fig. 31 ). Although the elevation of the deposit crest remained about the same for al1 three surveys (about $1,736 \mathrm{ft}$ ), the position of the crest and return-current channel changed considerably. Between April and September, the side of the deposit nearest the bank degraded, and the side toward the main channel aggraded, resulting in movement of the deposit crest toward the main channel. The upstream end of the deposit aggraded, and the return-current channel moved upstream. By January, the return-current channel had migrated back to the position of April, and the shape and position of the reattachment deposit were also similar to those of April. Most of the slope into the main channel was not mapped at this site because air entrained in the water column at National Rapid interfered with the depth-sounder signal. The slope was mapped at the upper end of the recirculation zone, however, and the maps show that the slope aggraded between April and September and degraded between September and January. Six profiles across the mapped areas illustrate these changes (fig. 32). Profile 6 shows that at the downstream end of the deposit, downstream from the return-current channel, aggradation took place between April and September and between September and January.

Aggradation between April and September was $879 \mathrm{ft}^{2}$, degradation was $161 \mathrm{ft}^{2}$, and net change was $+718 \mathrm{ft}^{2}$ (table 8). Between September and January, aggradation was $198 \mathrm{ft}^{2}$, degradation was $945 \mathrm{ft}^{2}$, and net change was $-747 \mathrm{ft}^{2}$. Net change for the entire period was $-29 \mathrm{ft}^{2}$. Average vertical change along profiles ranges from 0 to $+1.4 \mathrm{ft}$ from April to December and -0.2 to $-1.8 \mathrm{ft}$ from September to January (table 8 ). Estimated volume change was $+39,400 \mathrm{ft}^{3}$ between April and September; $-37,900 \mathrm{ft}^{3}$ between September and January; and $+1,500 \mathrm{ft}^{3}$ over the entire period.

A recirculation zone just below Nautiloid Canyon at river mile 34.8 was mapped on January 14, 1986, at discharges of 2,360 and $15,900 \mathrm{ft}^{3} / \mathrm{s}$ to determine the magnitude of short-term changes in the sand deposits. Low-flow and high-flow maps were drawn from 836 and 903 data points, respectively. The recirculation zone is more elongated than at Blacktail Rapid or Eminence Break Camp. The reattachment-deposit crest and return-current channel are the prominent features. A low area is 

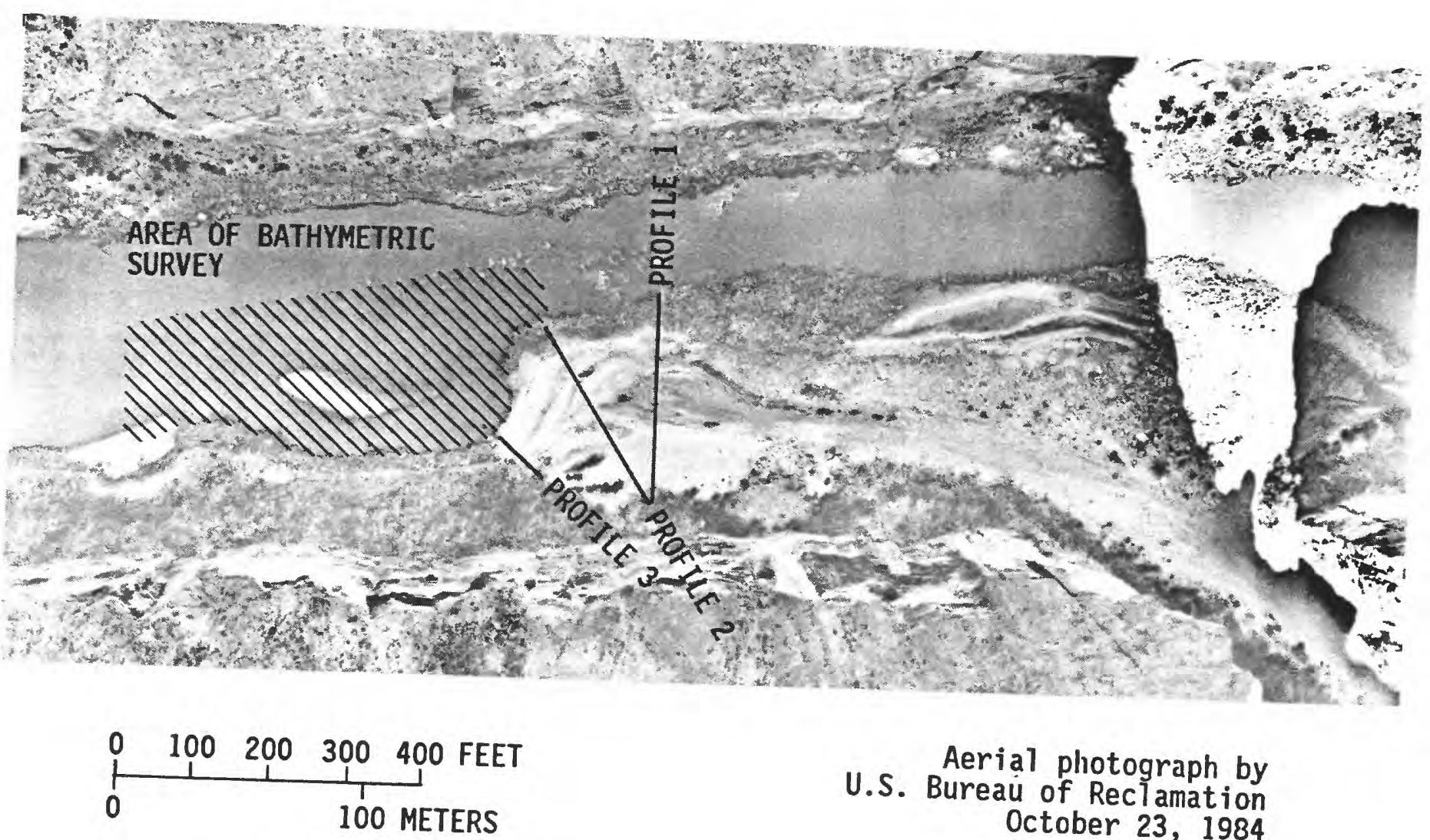

Aerial photograph by

U.S. Bureau of Reclamation October 23, 1984

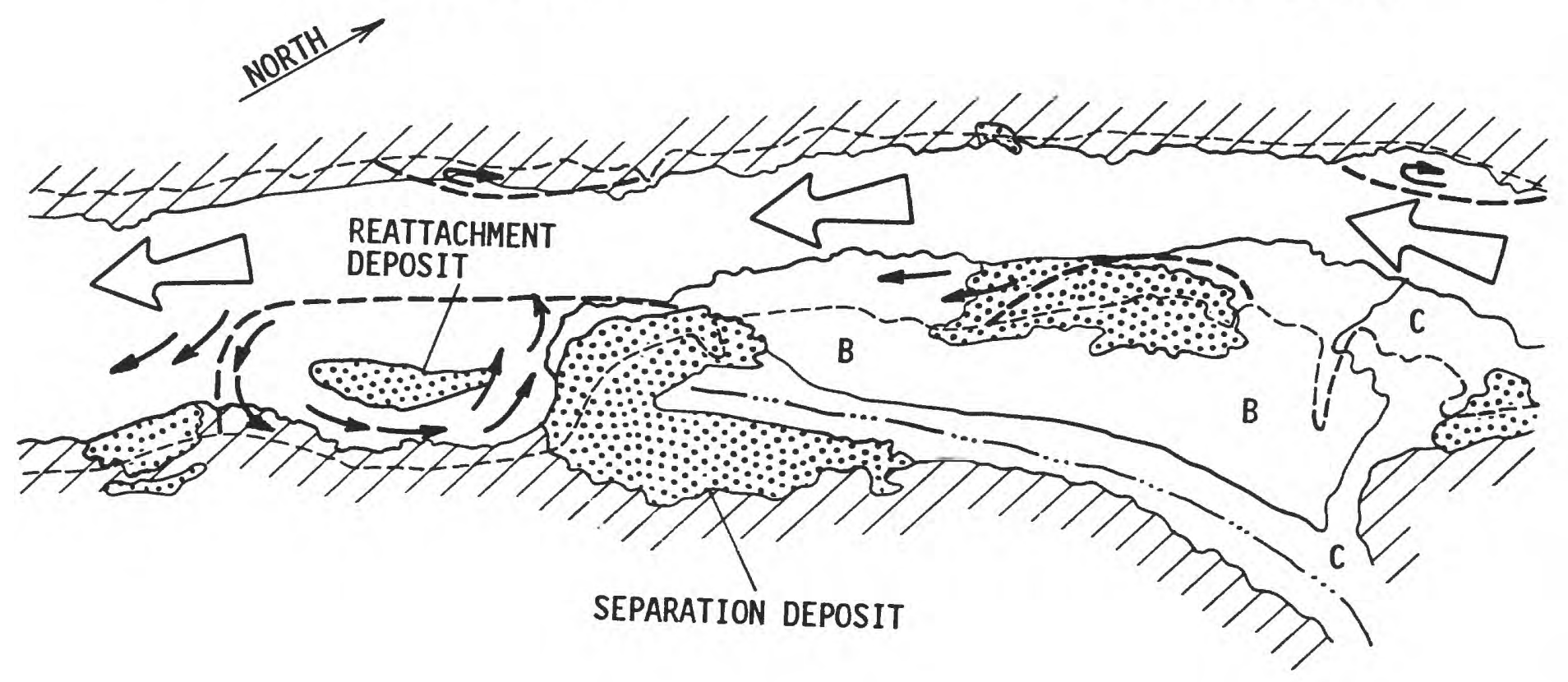

Figure 30.--Area of bathymetric survey, surficial geology, and hydrautic features at National Rapid. 


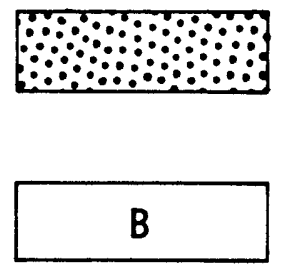

RIVER-DEPOSITED OR REWORKED VERY FINE TO MEDIUM SAND (October 21, 1984)

TRIBUTARY DEBRIS FAN-Boulders, cobbles, gravel, sand, poorly sorted; boulders cover more than 50 percent of surface area except in tributary streambed

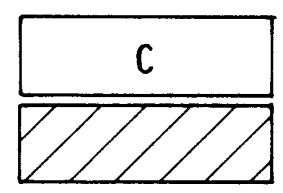

COBBLES AND GRAVEL

TALUS AND BEDROCK

EDGE OF WATER

October 21, 1984, discharge about 5,600 cubic feet per second

August 15, 1985, discharge about 22,000 cubic feet per second

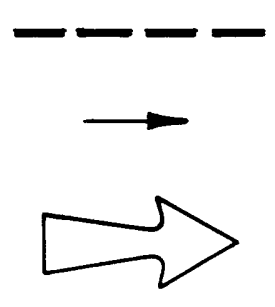

SEPARATION SURFACE, 22,000 CUBIC FEET PER SECOND

GENERALIZED SURFACE-FLOW DIRECTION IN

RECIRCULATION ZONES, 22,000 CUBIC FEET PER SECOND

SURFACE-FLOW DIRECTION OF MAIN CURRENT

PROFILE 1- LOCATION OF PROFILE LINES, SEE TABLE 13

Figure 30 . 


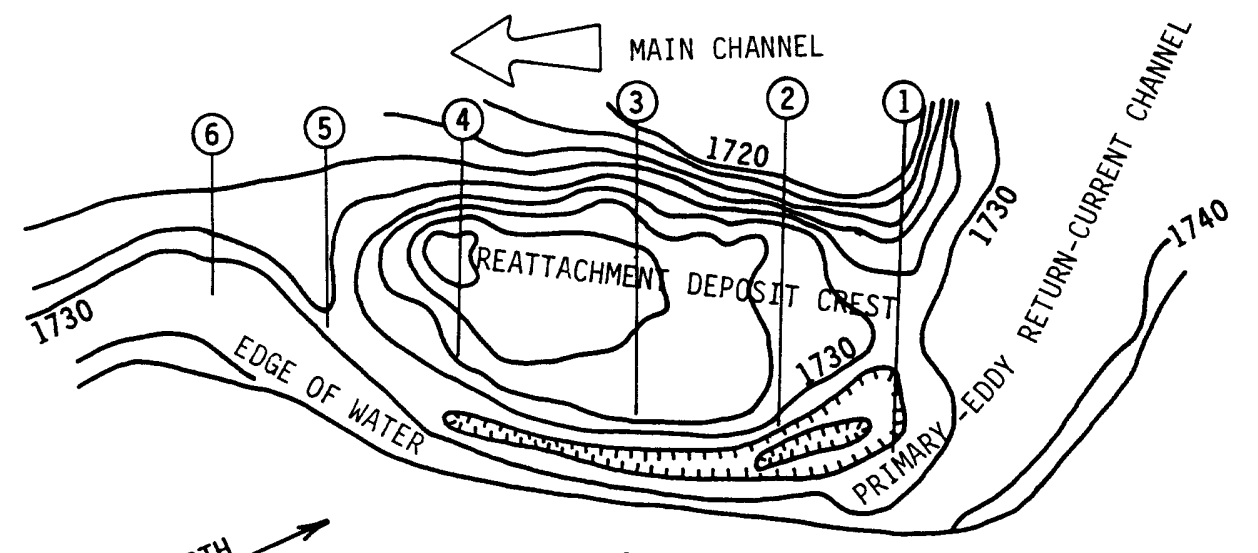

A.

Discharge, 20,800 cubic feet per second

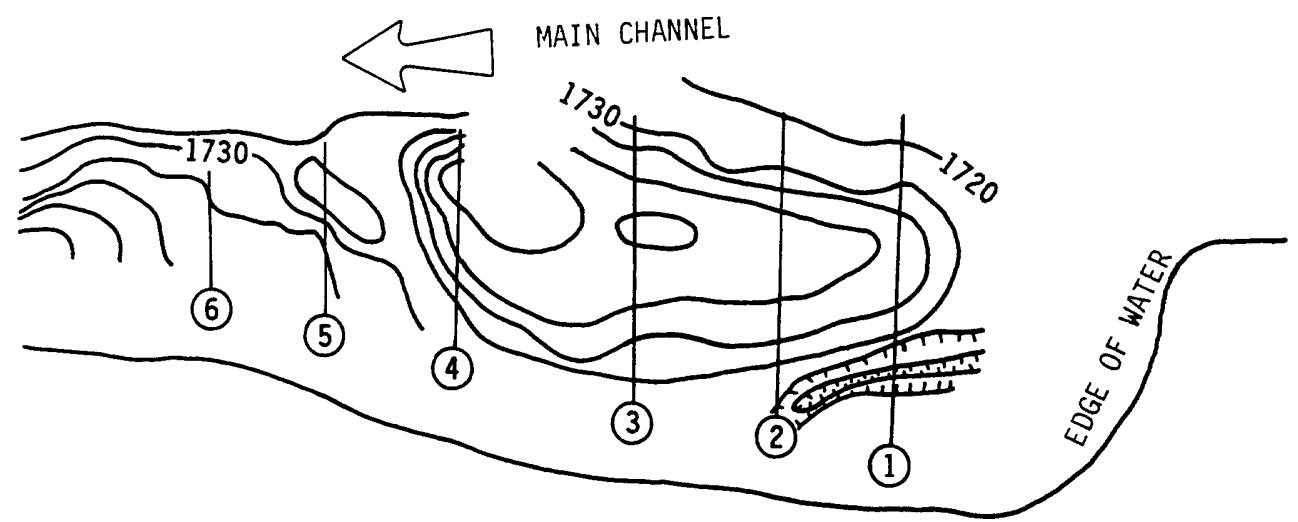

B.

Discharge, 21,200 cubic feet per second

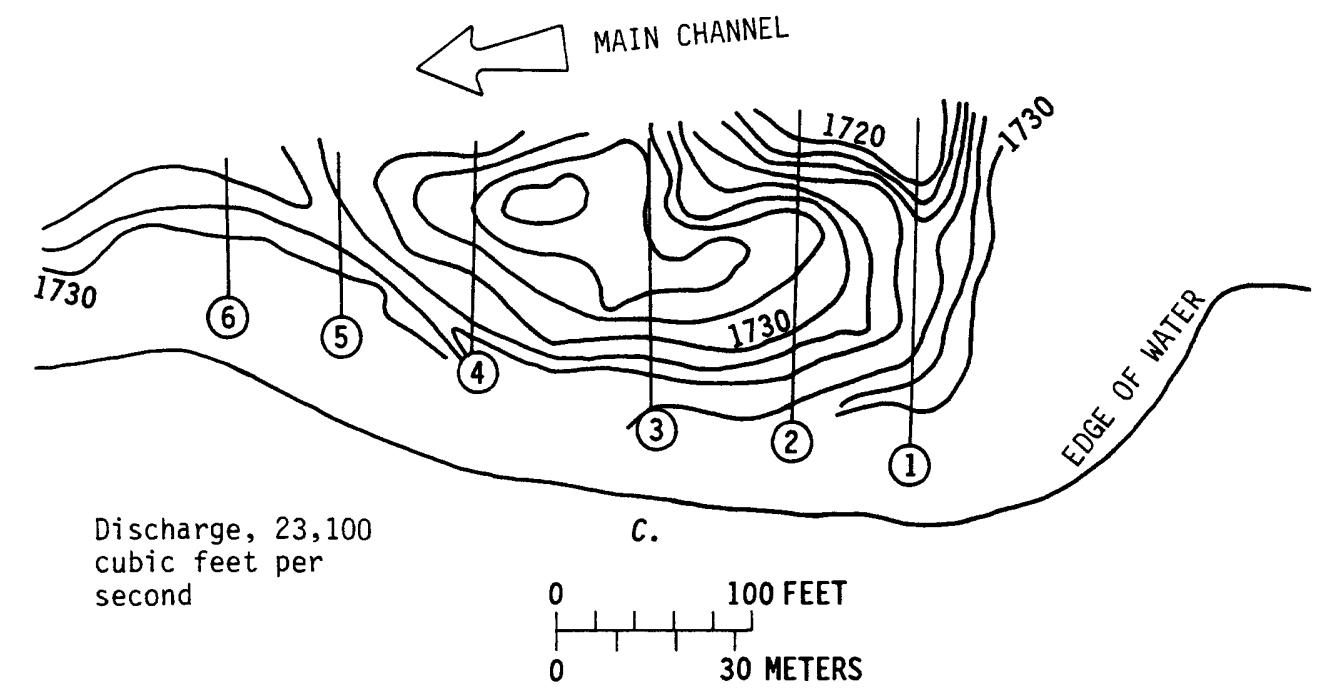

EXPLANATION

- $1730-$ BATHYMETRIC CONTOUR-Hachures indicate

depression. Elevations are related to

National Geodetic Vertical Datum of 1929.

Interval 10 and 2 feet

(6)

PROFILE LINE

Figure 31.--Bathymetric contours within a recirculation zone below National Rapid. A, On April 25, 1985. B, On September 10, 1985. C, On January. 28, 1986 . 

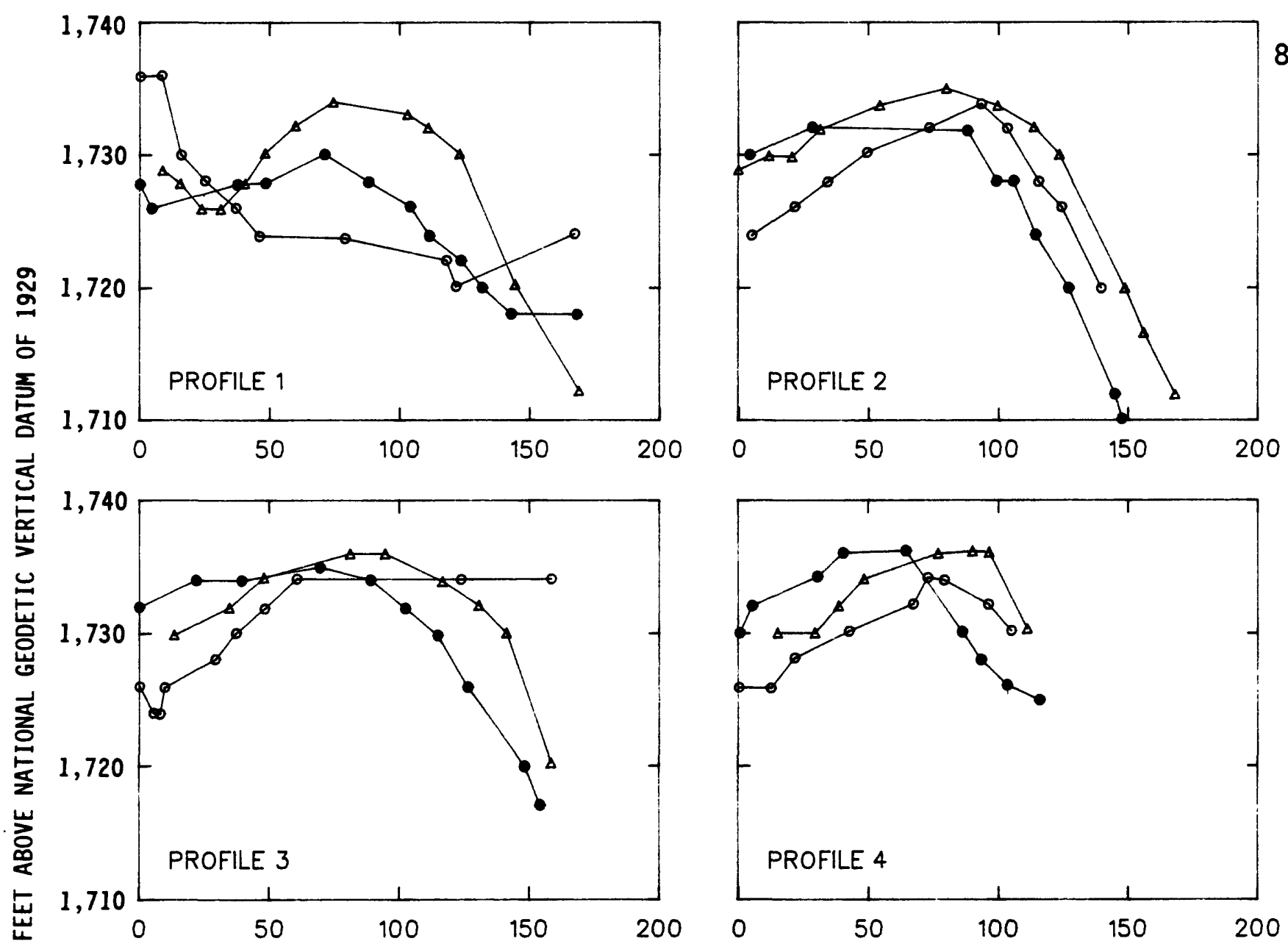

ż
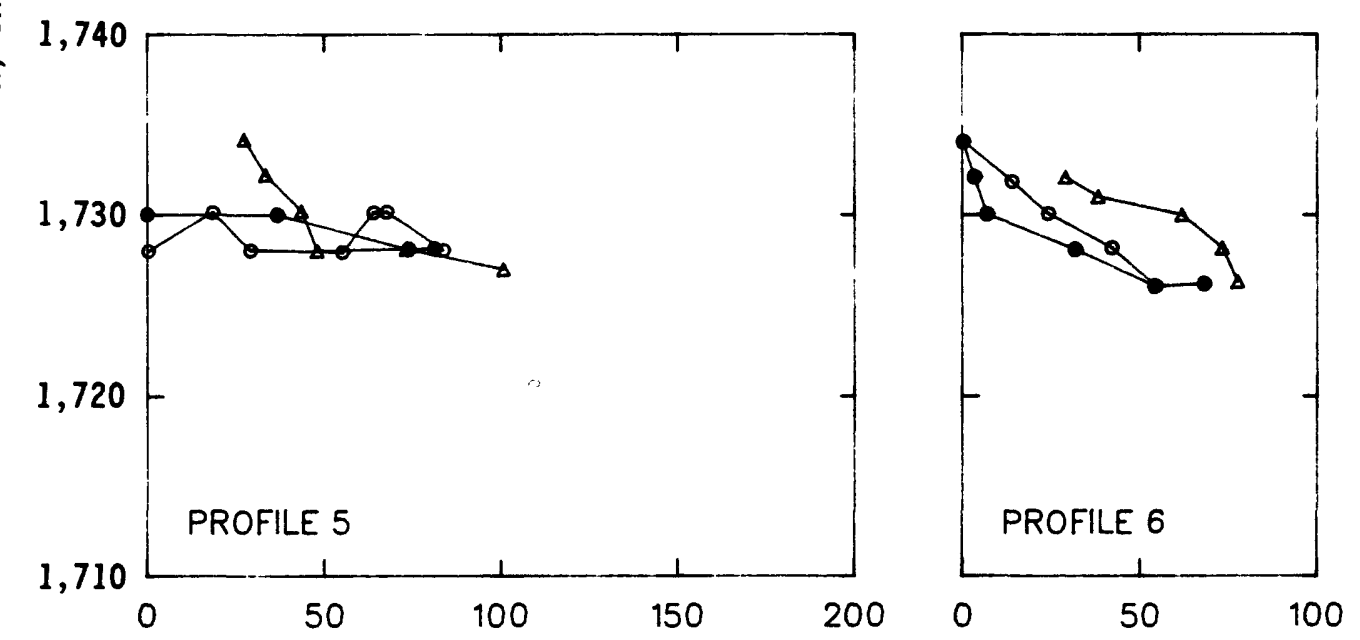

DISTANCE FROM POINT OF ORIGIN, IN FEET

EXPLANATION

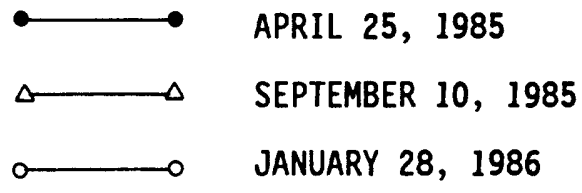

Figure 32.--Bed-surface profiles of a recirculation zone below National Rapid. 
present in the center of the deposit, and the deposit crest rises slightly as did the crest at Eminence Break Camp. The position uncertainty ranged from $4.5 \mathrm{ft}$ at the upper and lower edges and toward the bank to $11.4 \mathrm{ft}$ at the extreme edge toward the main channel. Although slight differences between the maps $c$ an be seen, the bottom configurations are almost identical. The differences are probably within the uncertainty caused by position uncertainty and that introduced by drawing contours from point data.

Bathymetric measurements document net degradation of the upper surface of recirculation zones at the three study sites where fluctuating flows were evaluated. Local aggradation of small areas did occur; however, net change at Eminence Break Camp, Blacktail Rapid, and National Rapid was degradational. The slope into the main channel aggraded at Blacktail Rapid. Pemberton and Randle (1987) predicted that a change from high steady flow to fluctuating flow would cause decreased sand transport in the main channel which would in turn cause main-channel aggradation. Aggradation along the slope at Blacktail Rapid, therefore, may be related to decreased main-channel sediment-transport capacity as well as delivery of sand from the upper surface of the recirculation zone. Behavior of recirculation zones between April and September differed at Eminence Break Camp and National Rapid. Measured changes, however, indicate sediment was exchanged between the main channel and the recirculation zone during this period of high steady flows.

Sand-storage changes of the upper surface and at edges of recirculation zones are not indicative of those in the nearby main channel. Bathymetric surveys also show that volume of aggradation and degradation of reattachment deposits far exceeds that of a typical separation deposit such as Eighteen Mile Wash. Bathymetric surveys cover most of the recirculation zones and measured volume changes indicate that sand is exchanged between recirculation zones and the main channel, as well as redistributed within recirculation zones. Although analysis of data from only a few sites (table 1) are presented, preliminary analysis of data from other sites indicates that the changes are representative of changes throughout the study reach.

\title{
AGGRADATION AND DEGRADATION OF ALLUVIAL SAND DEPOSITS, 1965-86
}

\author{
Changes in Alluvial Sand Deposits, 1973-84
}

Flow Characteristics

Between June 1973 and May 1983, daily discharge generally fluctuated to meet hydroelectric needs (fig. 2). During this period, the average daily fluctuation range was 13,000 to $15,000 \mathrm{ft}^{3} / \mathrm{s}$. The average daily range is defined as the difference between the average monthly maximum and average monthly minimum release from Glen Canyon Dam. Except for 1980, instantaneous peak discharge at Lees Ferry was less than $31,000 \mathrm{ft}^{3} / \mathrm{s}$. In 1980, mean daily discharge exceeded $30,000 \mathrm{ft}^{3} / \mathrm{s}$ on 8 days and peak discharge was $44,800 \mathrm{ft}^{3} / \mathrm{s}$. Discharge dramatically 
increased in June 1983 and then receded in August to steady discharges of about $28,000 \mathrm{ft}^{3} / \mathrm{s}$. In May 1984, discharge increased to about $45,000 \mathrm{ft}^{3} / \mathrm{s}$ and then decreased to steady discharges of about $28,000 \mathrm{ft}^{3} / \mathrm{s}$ in July (fig. 9). Between 0ctober 21 and 23, 1984, flow decreased to about $5,600 \mathrm{ft}^{3} / \mathrm{s}$.

\section{Changes in Deposits}

Large-scale changes in storage of sand in recirculation zones were evaluated by comparing inventories of exposed separation and reattachment deposits in 399 recirculation zones between river miles 0 and 118 (table 9). Because stage was very different in the two aerial photograph series in some reaches, only presence or absence of sand was noted and the area of sand was not measured. Also high flows scour and redistribute sand within recirculation zones. A decrease in area of sand may be the result of redistribution of sand within a recirculation zone and not represent net change in sand storage within the recirculation zone (fig. 19). Because comparison of inventories only indicates changes in presence of sand within recirculation zones, differences in inventories represent large-scale volume changes.

On the basis of this inventory, sand was eroded from reattachment deposits between river miles 0 and 36 and 77 and 118 . These included the narrowest reaches inventoried. The total number of separation deposits in these four reaches changed less than the number of reattachment deposits. Aggradation of reattachment deposits and minor aggradation of separation deposits occurred between river miles 36 and 77.

The most significant changes took place in the narrowest and steepest reaches as well as in those closest to Glen Canyon Dam (table 2). The change in reattachment deposits was slightly greater than the change in separation deposits. None of the deposits involved in these changes, however, had been inventoried as a campsite in 1973 or 1983 . The deposits that did increase or decrease in number were of sufficiently low elevation to not be considered as campsites.

Changes in area of major alluvial sand deposits during this period were measured for reaches between river miles 0 and 35.9 and river miles 122 and 150 where discharge in the 1973 and 1984 aerial photographs was approximately the same (fig. 4 and table 10). Major alluvial deposits were defined as those inventoried as campsites in 1973 or 1984 (Appendix A) and other alluvial deposits in the same recirculation zones. If a separation deposit had been inventoried as a campsite and a reattachment deposit existed in the same zone, its area was also measured. The number of recirculation zones where area changes were measured was less than 45 percent of the total number of recirculation zones where presence or absence of deposits were determined.

Changes in area of reattachment deposits do not necessarily reflect changes in volume of stored sand in recirculation zones because smaller deposits may be of higher elevation. As illustrated at Eighteen Mile Wash, volume at a separation deposit changed where area of deposit exposed at low discharge did not change. However, where area of 
separation or channel-margin deposits changed, net aggradation or degradation probably also occurred. Changes in area do indicate the extent of reworking of different types of deposits, and area changes are directly related to the size of campsites. Measured areas were those exposed at low discharges, and smaller areas of these deposits are available as campsites at higher discharges, particularly at reattachment deposits.

No significant change in total area of deposits was measured in any reach except between river miles 0 and 11.3. All the change measured in that segment was due to significant erosion of one point-bar deposit at river mile 1.9; the total area of separation or reattachment deposits showed no significant change. Two categories of reach and deposit type, however, significantly decreased in area: Separation deposits in Muav Gorge and reattachment deposits in Supai Gorge. Erosion of separation deposits in Muav Gorge is likely due to the low elevation of debris fans in this reach. Low-elevation debris fans were substantially overtopped by the high discharges of 1983. Decrease in area of reattachment deposits in Supai Gorge is consistent with a decrease in number of reattachment deposits in the same segment (table 10). Therefore decrease in area in this segment probably reflects degradation of the deposits. The area of channel-margin deposits increased.

Although on an aggregate basis, major alluvial deposits in most reaches did not change significantly in total exposed area, 70 percent of all deposits either increased or decreased in area (table 11). About half of these increased and half decreased in area. More than 40 percent of separation and upper-pool deposits did not change in area. In contrast, about 20 percent of reattachment and channel-margin deposits did not change. The dominant pattern of change of reattachment deposits was toward a decrease in area and of channel-margin deposits was toward an increase in area. Decreases in area of reattachment deposits were

Table 10.--Areas of major alluvial sand deposits in selected reaches, 1973 and 1984

[Values are in thousands of square feet]

\begin{tabular}{|c|c|c|c|c|c|c|c|c|c|c|c|c|}
\hline \multirow{3}{*}{$\begin{array}{l}\text { Reach } \\
\text { segment }\end{array}$} & \multicolumn{12}{|c|}{ Types of deposits } \\
\hline & \multicolumn{3}{|c|}{ Total } & \multicolumn{3}{|c|}{ Separation } & \multicolumn{3}{|c|}{ Reatt achment } & \multicolumn{3}{|c|}{ Channel margin } \\
\hline & 1973 & 1984 & Change & 1973 & 1984 & Change & 1973 & 1984 & Change & 1973 & 1984 & Change \\
\hline $0-11.3$ & $460-610$ & $370-450$ & (1) & $210-270$ & $210-250$ & (2) & $100-130$ & $84-100$ & (2) & ----- & --- & -- \\
\hline $\begin{array}{r}11.4- \\
22.5\end{array}$ & $540-670$ & $460-560$ & (2) & $350-430$ & $350-430$ & $(2)$ & $170-200$ & $86-110$ & $(1)$ & ------ & - - - & --- \\
\hline $\begin{array}{r}22.6- \\
35.9\end{array}$ & $480-620$ & $490-590$ & (2) & $280-360$ & $260-320$ & (2) & $150-200$ & $170-210$ & (2) & ----- & ---- & -- \\
\hline $\begin{array}{l}122- \\
125.5\end{array}$ & $300-380$ & $320-400$ & (2) & ---- & ------ & -- & $57-67$ & $59-72$ & (2) & $112-140$ & $140-180$ & $(2)$ \\
\hline $\begin{array}{r}125.6- \\
139.9\end{array}$ & $840-920$ & $810-990$ & (2) & $200-220$ & $220-260$ & $(2)$ & $120-130$ & $130-150$ & $(2)$ & $410-440$ & $370-450$ & $(2)$ \\
\hline $\begin{array}{r}140- \\
150\end{array}$ & $128-150$ & $120-150$ & (2) & $73-86$ & $55-67$ & (1) & 0 & 2 & -- & $50-59$ & $64-78$ & $(2)$ \\
\hline
\end{tabular}


concentrated in Supai Gorge and increases in area of channel-margin deposits were concentrated in Muav Gorge (table 11).

These conclusions refine the conclusions of Beus and others (1985) that aggradation of alluvial sand deposits had occurred throughout the river corridor. The sample of alluvial sand deposits studied by Beus and others (1985) included a high proportion of separation and channel-margin deposits, which in this study are shown to be stable or aggrading sites (table 12). Six separation deposits studied by Beus and others (1985) had net vertical aggradation and minor bank erosion. The general pattern of change at Eighteen Mile Wash during this period (fig. 29) was representative of other sites.

Ten study sites of Beus and others (1985) were channel-margin deposits. Erosion of deposits was measured in the narrow reaches of Supai Gorge, Upper Granite Gorge, and Muav Gorge. Eroded sites were typically small deposits mantling bedrock or talus and were associated with small recirculation zones. Larger channel-margin deposits in all reaches such as Lower Nankoweap Rapid, above Grapevine Rapid, and Granite Park Camp underwent vertical aggradation and some bank erosion. Only two reattachment deposits were surveyed, and aggradation of the upper surface of each deposit was measured.

\section{Changes in Alluvial Sand Deposits, High Flows, May 1985}

Flow Characteristics

On May 17, 1985, discharge at Lees Ferry increased from $26,000 \mathrm{ft}^{3} / \mathrm{s}$ at 0900 hours to $45,800 \mathrm{ft}^{3} / \mathrm{s}$ at 1730 hours. Except for a 6 -day period when mean daily discharge was about $30,000 \mathrm{ft}^{3} / \mathrm{s}$, discharges that exceeded $40,000 \mathrm{ft}^{3} / \mathrm{s}$ continued unti1 June 25. Discharge then decreased to 1 ess than $30,000 \mathrm{ft}^{3} / \mathrm{s}$ (fig. 28). The resulting hydrograph is similar to those of 1984 and 1986:

\section{Changes in Deposits}

Separation deposits were surveyed at Badger Creek Rapid, Eighteen Mile Wash, Twenty Mile Camp, Eminence Break Camp, and National Rapid soon after the onset of high flows in May 1985 (table 1). These sites were al so surveyed after recession of high flows in August. In all cases, net aggradation occurred in small areas associated with low-velocity areas upstream from the primary-eddy return current.

Data collected at Eighteen Mile Wash discussed in the section "Aggradation and Degradation at Eighteen Mile Wash, 1965-86" shows that aggradation followed degradation. Aggradation caused the deposit to regain its approximate former shape and size.

At Badger Creek Rapid in May 1985, a wave-cut scarp developed as 0.5-foot-amplitude waves impinged on the deposit face during the increase 
Table 11.-- Number of deposits that underwent change, 1973-84

\begin{tabular}{|c|c|c|c|c|c|c|c|c|c|c|c|c|}
\hline \multirow{3}{*}{$\begin{array}{l}\text { Reach } \\
\text { segment }\end{array}$} & \multicolumn{12}{|c|}{ Types of deposits } \\
\hline & \multicolumn{3}{|c|}{ Separation } & \multicolumn{3}{|c|}{ Reattachment } & \multicolumn{3}{|c|}{ Channel margin } & \multicolumn{3}{|c|}{ Upper pool } \\
\hline & Gain & Loss & $\begin{array}{c}\text { No } \\
\text { change }\end{array}$ & Gain & Loss & $\begin{array}{c}\text { No } \\
\text { change }\end{array}$ & Gain & Loss & $\begin{array}{c}\text { No } \\
\text { change }\end{array}$ & Gain & Loss & $\begin{array}{c}\text { No } \\
\text { change }\end{array}$ \\
\hline $\begin{array}{l}0-11.3 \\
11.4-22.5 \\
22.5-35.9 \\
122-125.5 \\
125.6-139.9 \\
140-150\end{array}$ & $\begin{array}{l}1 \\
4 \\
2 \\
1 \\
6 \\
0 \\
\end{array}$ & $\begin{array}{l}0 \\
3 \\
6 \\
1 \\
3 \\
2 \\
\end{array}$ & $\begin{array}{l}3 \\
6 \\
6 \\
0 \\
5 \\
1 \\
\end{array}$ & $\begin{array}{l}2 \\
0 \\
1 \\
2 \\
2 \\
1 \\
\end{array}$ & $\begin{array}{l}2 \\
6 \\
1 \\
0 \\
2 \\
0 \\
\end{array}$ & $\begin{array}{l}1 \\
1 \\
2 \\
1 \\
0 \\
0 \\
\end{array}$ & $\begin{array}{l}0 \\
0 \\
0 \\
7 \\
7 \\
7 \\
\end{array}$ & $\begin{array}{l}0 \\
0 \\
0 \\
2 \\
9 \\
0 \\
\end{array}$ & $\begin{array}{l}0 \\
0 \\
0 \\
0 \\
4 \\
2 \\
\end{array}$ & $\begin{array}{l}0 \\
0 \\
0 \\
1 \\
0 \\
0 \\
\end{array}$ & $\begin{array}{l}0 \\
2 \\
1 \\
0 \\
1 \\
0 \\
\end{array}$ & $\begin{array}{l}0 \\
1 \\
2 \\
1 \\
2 \\
0 \\
\end{array}$ \\
\hline Total & 14 & 15 & 21 & 8 & 11 & 5 & 21 & 11 & 6 & 1 & 4 & 6 \\
\hline Percent & 28 & 30 & 42 & 33 & 46 & 21 & 55 & 29 & 16 & 9 & 36 & 55 \\
\hline
\end{tabular}

Table 12.--Classification of deposits studied by Howard (1975) and Beus and others (1985) 1

Types of deposits and river-mile position

\begin{tabular}{|c|c|c|c|}
\hline Separation & Reattachment & Channel margin & Upper pool \\
\hline $\begin{array}{l}\text { Eighteen Mile Wash } \\
\text { (18.2) [18.1L] } \\
\text { Nautiloid Canyon } \\
\text { (34.7) [34.7L] } \\
\text { Below Little } \\
\text { Colorado River } \\
\text { confluence } \\
\text { (61.8) [61.7R] } \\
\text { Tanner Mine } \\
\text { (65.5) [65.6L] } \\
\text { Unkar Indian Village } \\
\text { (72.2) [72.5R] } \\
\text { Bedrock Rapids } \\
\text { (131) [131.0R] }\end{array}$ & $\begin{array}{l}\text { Nineteen Mile Wash2 } \\
\text { (19.3) [19.0L] } \\
\text { One Hundred Ninety } \\
\text { Mile (190.2) }\end{array}$ & $\begin{array}{l}\text { Nineteen Mile Wash2 } \\
\text { (19.3) [19.0L] } \\
\text { Lower Nankoweap } \\
\text { (53) [53.2R] } \\
\text { Grapevine } \\
\text { (81.1) [81.1L] } \\
\text { One Hundred Nine Mile } \\
\text { (109.4) } \\
\text { Wa1thenberg Canyon } \\
\text { (112.2) } \\
\text { Upper 124.5 Mile } \\
\text { Canyon (124.3) } \\
\text { The Ledges } \\
\text { (151.6) [151.6R] } \\
\text { Nationa) Canyon } \\
\text { (165.5) [166.4L] } \\
\text { Lower Lava (180.9) } \\
\text { Granite Park (208.8) }\end{array}$ & $\begin{array}{l}\text { Upper Granite Rapid } \\
\text { (93.2) [93.1L] } \\
\text { Blacktai] Canyon } \\
(120.1) \text { [120.0R] }\end{array}$ \\
\hline
\end{tabular}

'Study site names are those of Beus and others (1985). River mile in brackets is river mile used in Appendix $A$ of this report. L, left side of river; $R$, right side of river.

${ }^{2}$ Nineteen Mile Wash had 1 profile line across reattachment deposit and 1 profile line across channel-margin deposit. 
in discharge. Aggradation of about $0.5 \mathrm{ft}$ however was measured between May and August. This aggradation resulted in a beach profile parallel to the slope that was measured below the eroding scarp in May.

The reattachment deposit at Opposite Nineteen Mile Canyon was surveyed during high flows in 1985. Surveys made by wading across the deposit indicated that the deposit was at approximately the same elevation as that of the previous summer, although it was probably smaller in size. The crest of the deposit was within about $1 \mathrm{ft}$ of the water surface. Following the recession of the flood of 1985, however, the crest lowered approximately $3 \mathrm{ft}$, al though it retained its general shape. These changes indicate that the shape of the deposit changed with onset of high flows and then readjusted during recession of the high flows. Comparisons of bathymetric surveys at Eminence Break Camp and National Rapid indicate that these reattachment deposits degraded between April and September despite retaining their overall shape. These observations suggest that reattachment deposits were entrained during these high flows.

\section{Changes of Alluvial Sand Deposits During Strongly Fluctuating Flow, October 1985 to January 1986}

Flow Characteristics

Between October 1, 1985, and January 15, 1986, releases from Glen Canyon Dam fluctuated widely (fig. 2). Average monthiy peak release during this time was between 19,300 and $20,300 \mathrm{ft}^{3} / \mathrm{s}$, and average monthly low release was between 1,800 and $5,500 \mathrm{ft}^{3} / \mathrm{s}$. Monthly mean discharge decreased from between 23,400 and $28,500 \mathrm{ft}^{3} / \mathrm{s}$ for the period July to September 1985 to less than $12,000 \mathrm{ft}^{3} / \mathrm{s}$ during this special fluctuatingflow study period. The last previous month when monthiy mean discharge was less than $12,000 \mathrm{ft} 3 / \mathrm{s}$ was March 1983. The average daity range of fluctuations was $15,100 \mathrm{ft} 3 / \mathrm{s}$ in $0 c$ tober, $14,000 \mathrm{ft}^{3} / \mathrm{s}$ in November, and $18,500 \mathrm{ft}^{3} / \mathrm{s}$ in December 1985. During the 1976 to 1983 period, 41 percent of all months had average fluctuations less than $14,000 \mathrm{ft}^{3} / \mathrm{s}$. During this same period, 21 percent of all months had fluctuations between 14,000 and $16,000 \mathrm{ft}^{3} / \mathrm{s}$. Average fluctuations in excess of $18,000 \mathrm{ft}^{3} / \mathrm{s}$ were equaled or exceeded only in 9 percent of all those months. Therefore, the fluctuation range of October and November 1985 was representative of a median range of fluctuations during the 1976 to 1983 period and the range in December 1985 was representative of a more infrequent operations regime. Except for the period immediately following official closure of Glen Canyon Dam in 1963, however, no precedent existed for the occurrence of widely fluctuating flows preceded by a lengthy period of steady flow.

\section{Changes in Deposits}

Although surveys along some profiles documented aggradation between October 1, 1985, and January 1986, most measurements documented degradation (table 13). Of 41 profile lines at the 13 study sites that 
Table 13.--Summary of measured changes at 20 sites during fluctuating flow, October 1985 to mid-January 1986

\begin{tabular}{|c|c|c|c|c|c|c|}
\hline $\begin{array}{l}\text { River } \\
\text { mile }\end{array}$ & Deposit type & Date & Profile & $\begin{array}{l}\text { Length } \\
\text { of sec- } \\
\text { tion, } \\
\text { in feet }\end{array}$ & $\begin{array}{l}\text { Average } \\
\text { vertical } \\
\text { change }\end{array}$ & Description \\
\hline \multicolumn{7}{|c|}{ Above Cathedral Wash } \\
\hline 2.5 & Reattachment & $\begin{array}{c}10-04-85 \\
\text { to } \\
01-09-86\end{array}$ & $\frac{1}{2}$ & $\begin{array}{l}57 \\
45\end{array}$ & $\begin{array}{l}+0.6 \\
-0.1\end{array}$ & $\begin{array}{l}\text { Profile } 1 \text { across } \\
\text { crest; profile } 2 \\
\text { downstream of } \\
\text { reattachment } \\
\text { point }\end{array}$ \\
\hline
\end{tabular}

Badger Creek Rapid

\begin{tabular}{lccccc}
\hline 7.9 Separation & $10-05-85$ & 1 & 54 & +0.1 & Figure 5 \\
& to & 2 & 85 & -0.7 & \\
& $01-11-86$ & 3 & 90 & +2.0 & \\
\hline
\end{tabular}

Soap Creek Rapid

\begin{tabular}{lccccc}
\hline 11.4 Separation & $09-21-85$ & 1 & 87 & -0.1 & Separation point \\
& to & 2 & 83 & -0.3 & migrates down- \\
& $01-12-86$ & 3 & 53 & -0.6 & stream through \\
& & 4 & 35 & -0.7 & all cross \\
& & 5 & 39 & -0.7 & sections \\
& & 6 & 37 & -0.3 & \\
& & 6 & 37 & -0.3 & \\
\hline
\end{tabular}

Below Salt Water Wash

\begin{tabular}{lccccc}
\hline 12.2 Separation & $10-08-85$ & 1 & 16 & +0.4 & Low-velocity area \\
& to & 2 & 57 & -0.2 & \\
& $01-13-86$ & 3 & 45 & +0.1 & \\
\hline
\end{tabular}

See footnotes at end of table. 
Table 13. --Summary of measured changes at 20 sites during fluctuating flow, October 1985 to mid-January 1986--Cont inued

\begin{tabular}{|c|c|c|c|c|c|c|}
\hline $\begin{array}{l}\text { River } \\
\text { mile }\end{array}$ & Deposit type & Date & Profile & $\begin{array}{l}\text { Length } \\
\text { of sec- } \\
\text { tion, } \\
\text { in feet } 1\end{array}$ & $\begin{array}{l}\text { Average } \\
\text { vertical } \\
\text { change }\end{array}$ & Description \\
\hline
\end{tabular}

Eighteen Mile Wash

\begin{tabular}{lrllll}
\hline 18.1 Separation & $10-09-85$ & 1 & 20 & -0.0 & Figure 12 \\
& to & 2 & 90 & -2.2 & \\
& $01-13-86$ & 3 & 10 & -2.72 & \\
\hline
\end{tabular}

Opposite Nineteen Mile Canyon

\begin{tabular}{|c|c|c|c|c|c|c|}
\hline 19.0 & Reattachment & $\begin{array}{c}10-10-85 \\
\text { to } \\
01-14-86\end{array}$ & $\begin{array}{l}1 \\
2\end{array}$ & $\begin{array}{l}57 \\
30\end{array}$ & $\begin{array}{l}-0.3 \\
-0.3\end{array}$ & $\begin{array}{l}\text { Profile } 1 \text { across } \\
\text { bar crest; } \\
\text { profile } 2 \text { down- } \\
\text { stream from } \\
\text { reattachment } \\
\text { point }\end{array}$ \\
\hline
\end{tabular}

Twenty Mile Camp

\begin{tabular}{lcllll}
\hline 19.8 Separation & $\begin{array}{c}10-11-85 \\
\text { to } \\
01-14-86\end{array}$ & 1 & 17 & -0.5 & $\begin{array}{c}\text { About } 120 \text { feet } \\
\text { downstream of } \\
\text { separation point }\end{array}$ \\
\hline
\end{tabular}

Twenty-Nine Mile Rapid

\begin{tabular}{|c|c|c|c|c|c|c|}
\hline 29.2 & Separation & $\begin{array}{c}10-11-85 \\
\text { to } \\
01-15-86\end{array}$ & $\begin{array}{l}1 \\
2 \\
3\end{array}$ & $\begin{array}{l}43 \\
42 \\
47\end{array}$ & $\begin{array}{l}-0.1 \\
-2.8 \\
-3.5\end{array}$ & Figure 34 \\
\hline \multicolumn{7}{|c|}{ Nautiloid Canyon } \\
\hline 34.7 & Separation & $\begin{array}{c}10-12-85 \\
\text { to } \\
01-14-86\end{array}$ & $\begin{array}{l}1 \\
2 \\
3 \\
4\end{array}$ & $\begin{array}{l}9 \\
17 \\
20 \\
20\end{array}$ & $\begin{array}{l}-0.6 \\
+0.2 \\
+0.6 \\
-1.2\end{array}$ & $\begin{array}{l}\text { Profiles located } \\
\text { progressively } \\
\text { farther down- } \\
\text { stream }\end{array}$ \\
\hline
\end{tabular}

See footnotes at end of table. 
98

Table 13. - - Summary of measured changes at 20 sites during fluctuating flow, October 1985 to mid-January 1986--Cont inued

River
mile Deposit type Date Profile $\begin{gathered}\text { of sec- Average } \\ \text { tion, } \\ \text { in feet }\end{gathered}$ vertical
change $\quad$ Description

Eminence Break Camp

\begin{tabular}{lccccc}
\hline 44.2 Separation & $10-12-85$ & 1 & 18 & -0.1 & Figure 14 \\
& to & 2 & 70 & +0.0 & \\
& $01-16-86$ & 3 & 29 & -1.0 & \\
& & 4 & 26 & +1.7
\end{tabular}

Saddle Canyon ${ }^{3}$

\begin{tabular}{cccccc}
\hline 47.2 Reattachment & $09-24-85$ & 1 & 60 & -0.2 & Figure 17 \\
& to & 2 & 89 & -0.1 & \\
& $01-18-86$ & 3 & 68 & -0.2 \\
& & 4 & 20 & -1.2 \\
& & 5 & 25 & -1.2 \\
& & 6 & 16 & -1.4
\end{tabular}

Above Grapevine Rapid ${ }^{3}$

\begin{tabular}{|c|c|c|c|c|c|c|}
\hline 81.1 & Channel & $\begin{array}{c}10-15-85 \\
\text { to } \\
01-21-86\end{array}$ & $\begin{array}{l}1 \\
2\end{array}$ & $\begin{array}{l}21 \\
22\end{array}$ & $\begin{array}{l}-1.0 \\
-1.1\end{array}$ & $\begin{array}{l}\text { Profile } 1 \text { between } \\
\text { separation and } \\
\text { reattachment } \\
\text { points; profile } \\
2 \text { near reattach- } \\
\text { ment point }\end{array}$ \\
\hline
\end{tabular}

Ninety-One Mile Creek ${ }^{3}$

\begin{tabular}{lccrcc}
\hline 91.0 Separation & $\begin{array}{c}10-15-85 \\
\text { to }\end{array}$ & 1 & 15 & -1.3 & $\begin{array}{c}\text { Profile 1 near } \\
\text { separation } \\
\text { point; profile 2 } \\
\text { primary-eddy } \\
\text { current }\end{array}$ \\
\hline
\end{tabular}

See footnotes at end of table. 
Table 13. - - Summary of measured changes at 20 sites during fluctuating flow, October 1985 to mid-January 1986--Cont inued

\begin{tabular}{|c|c|c|c|c|c|c|}
\hline $\begin{array}{l}\text { River } \\
\text { mile }\end{array}$ & Deposit type & Date & Profile & $\begin{array}{l}\text { Length } \\
\text { of sec- } \\
\text { tion, } \\
\text { in feet }\end{array}$ & $\begin{array}{l}\text { Average } \\
\text { vertical } \\
\text { change }\end{array}$ & Description \\
\hline \multicolumn{7}{|c|}{ National Rapid } \\
\hline 166.5 & Separation & $\begin{array}{c}10-21-85 \\
\text { to } \\
01-08-86\end{array}$ & $\begin{array}{l}1 \\
2 \\
3\end{array}$ & $\begin{array}{l}66 \\
32 \\
--\end{array}$ & $\begin{array}{r}-0.4 \\
+0.3 \\
0.0\end{array}$ & Figure 30 \\
\hline \multicolumn{7}{|c|}{ Fern Glen Rapid } \\
\hline 168.0 & Separation & $\begin{array}{l}10-01-85 \\
\text { to } \\
01-08-86 \\
\text { USBR }\end{array}$ & $\begin{array}{l}1 \\
2 \\
3 \\
4 \\
5\end{array}$ & $\begin{array}{r}3 \\
15 \\
72 \\
-- \\
10\end{array}$ & $\begin{array}{l}+0.7 \\
+2.8 \\
+1.7 \\
-0.0 \\
-0.2\end{array}$ & $\begin{array}{l}\text { Profiles located } \\
\text { progressively } \\
\text { farther down- } \\
\text { stream }\end{array}$ \\
\hline \multicolumn{7}{|c|}{ Pumpkin Springs ${ }^{3}$} \\
\hline 212.9 & $\begin{array}{l}\text { Channel- } \\
\text { margin; } \\
\text { reattachment }\end{array}$ & $\begin{array}{l}10-23-85 \\
\text { to } \\
01-31-86\end{array}$ & $\begin{array}{l}1 \\
2\end{array}$ & $\begin{array}{l}18 \\
25\end{array}$ & $\begin{array}{l}-7.2 \\
-1.8\end{array}$ & $\begin{array}{l}\text { Profile 1 near } \\
\text { reattachment } \\
\text { point; profile } 2 \\
\text { downstream from } \\
\text { reattachment } \\
\text { point }\end{array}$ \\
\hline
\end{tabular}

${ }^{1}$ Length of section is that portion of cross section over which survey comparisons could be made, and which were both affected by fluctuating flows; actual cross sections are longer.

${ }^{2}$ Average vertical change equals cross-section area divided by horizontal length of cross section.

${ }^{3}$ Surveys in January 1986 after conclusion of special fluctuating-flow study period; some change may be due to resumption of higher flows beginning January 17, 1986.

are separation deposits, about one-quarter of the 1 ines showed net aggradation and about two-thirds of the profiles showed net degradation (fig. 33). The mean net change along these profile lines was $-0.65 \mathrm{ft}$. A part of every separation deposit degraded, and at seven sites, no areas of aggradation were measured. Erosion in excess of $1 \mathrm{ft}$ was measured at profiles at six sites that were at widely spaced locations. Erosion associated with the special fluctuating-flow study period therefore was typical of sites throughout the Grand Canyon. At the end of the period, cutbanks existed at many sites, which indicated that profiles were not yet stable.

Channel-geometry characteristics of these study sites were compared. Five of the six sites where significant erosion was measured are located in narrow reaches where stage changes during fluctuating 


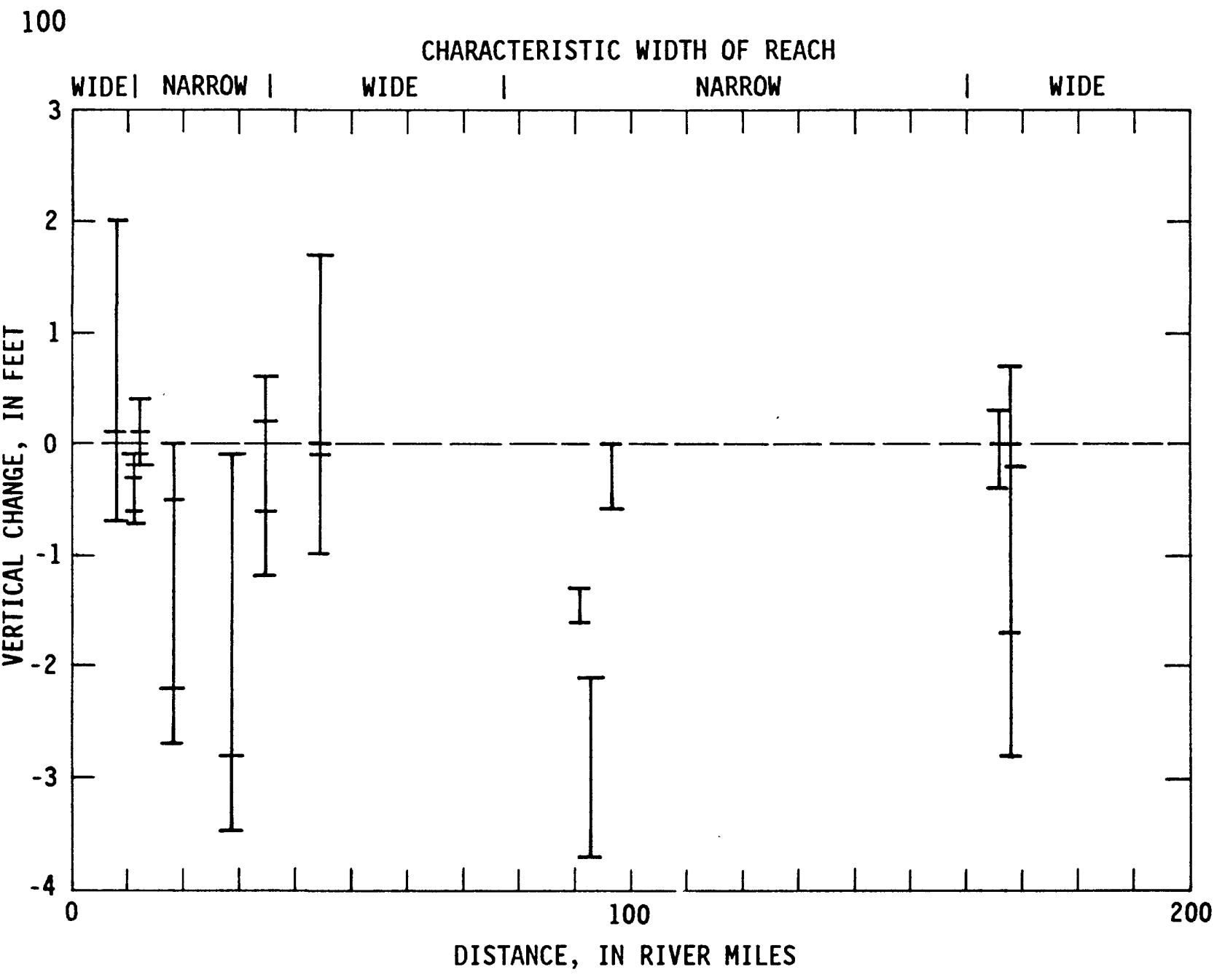

EXPLANATION

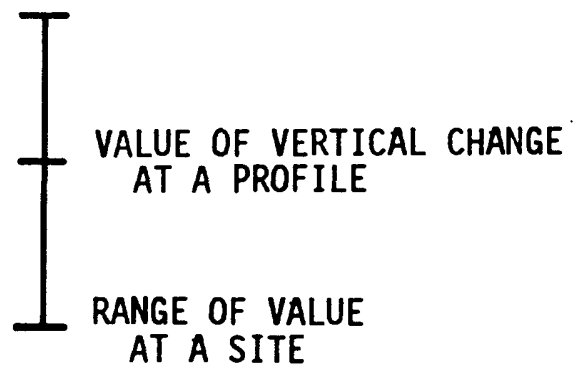

Figure 33.--Vertical change along profile lines at 13 separation deposits between October 1985 and January 1986. 
discharge are greatest. Significant erosion was not related to slope of the water surface through the constriction or construction ratio of the site.

Locations of significant erosion were not related to locations of highest velocities in recirculation zones. In some cases, erosion occurred where nearshore currents were less than $1 \mathrm{ft} / \mathrm{s}$ such as at Eighteen Mile Wash. At these sites, saturation of the lower part of a high-elevation separation deposit is sufficient to cause bank failure. Failure occurred even where waves were absent.

At each site, the amount of erosion increased with distance downstream from the separation point. For example, at Twenty-Nine Mile Rapid, the deposit degraded slightly at a profile $100 \mathrm{ft}$ downstream from the separation point (fig. 34, profile 1), but degraded about $2.8 \mathrm{ft}$ along a profile $140 \mathrm{ft}$ farther downstream (fig. 34, profile 2). Al so downstream migration of the separation point at that point exposed low-elevation areas of the upstream part of the separation deposit to downstream-directed currents as al so occurred at Badger Creek Rapid (fig. 5) and at Eighteen Mile Wash. Where underlying debris-fan materials were exposed, degradation in the upstream part was restricted. These trends indicate that erosion tended to eliminate unarmored parts of separation deposits especially where they project downstream from the debris-fan deposit.

The upper surface of most surveyed reattachment deposits degraded during fluctuating flow. These changes were documented by bathymetric surveys at Eminence Break Camp, Blacktail Rapid, and National Rapid (table 8) and topographic surveys Opposite Nineteen Mile Canyon, Saddle Canyon, and Hundred Twenty-Two Mile Creek (table 14). Only the deposit at the site Above Cathedral Wash aggraded. At this site, increase in volume occurred by vertical aggradation of about $0.5 \mathrm{ft}$ as well as by upstream slipface migration of 10-20 ft. Local aggradation of parts of the reattachment-deposit crest occurred at Eminence Break Camp.

At the site, Above Cathedral Wash, constriction-ratio and reach-segment characteristics are similar to other sites and variation in these parameters do not explain the apparently unique behavior of the site. Proximity to the Paria River, which contributes a large amount of sediment, may be important. Twenty percent of the aggradation at the site was caused by sediment delivered by the Paria River on October 10 and 11 . Between river miles 0 and 5 , sediment finer than boulders covered 75 percent of the bed, a large amount for the Colorado River in the park, and aggradation may have resulted from greater local availability of sand-size bed material.

As described in the section entitled "Bathymetric Surveys," aggradation occurred on the slope extending from the crest of the reattachment deposit to the thalweg at Blacktail Rapid. Decreased sediment transport is predicted by Pemberton and Randle (1987) throughout the river corridor and aggradation along this slope probably occurred at other sites. 


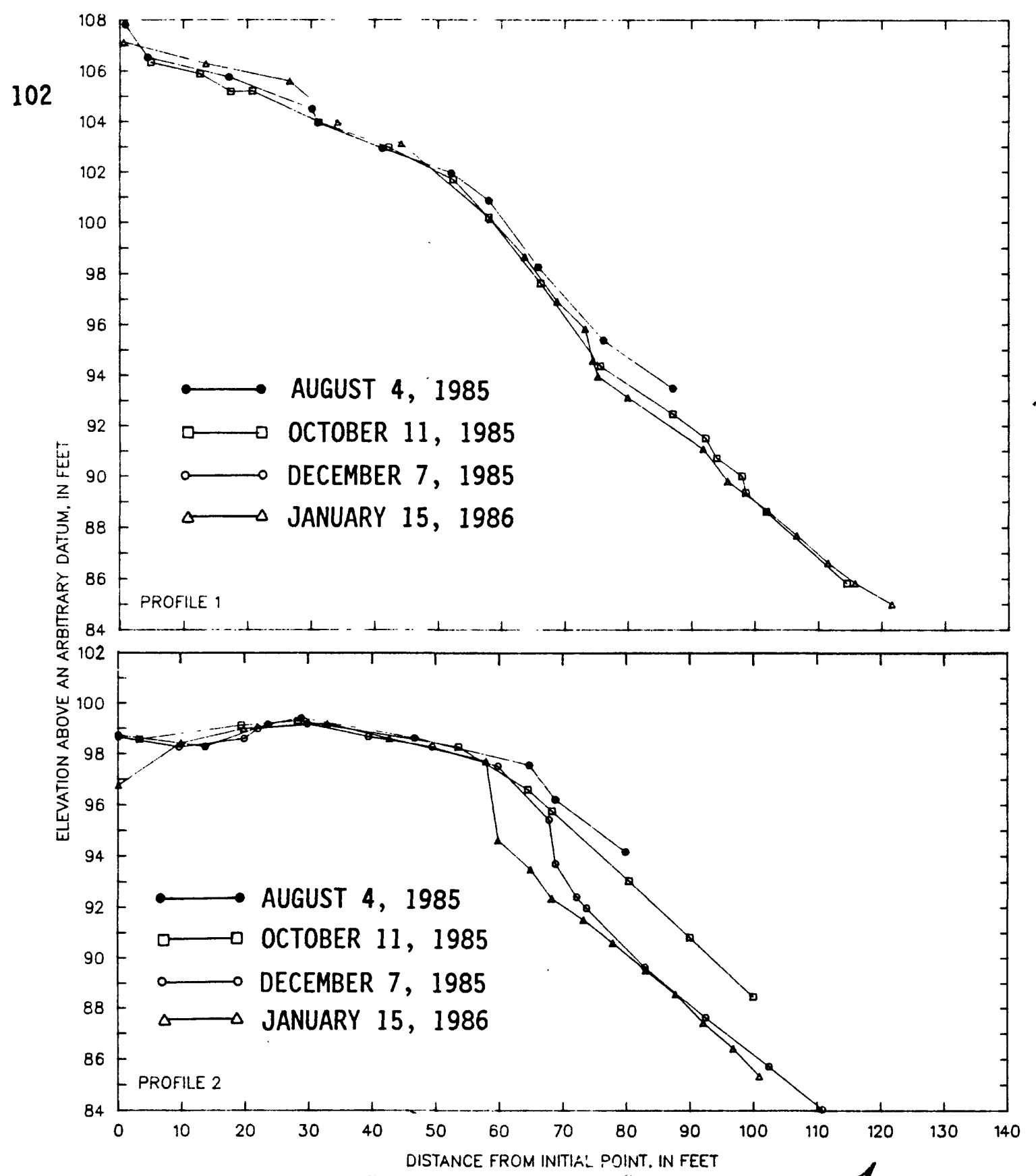

\section{$\begin{array}{llll}0 & 100 \quad 200 \quad 300 \quad 400 \text { FEET } \\ 0 & & 100 \text { METERS }\end{array}$}

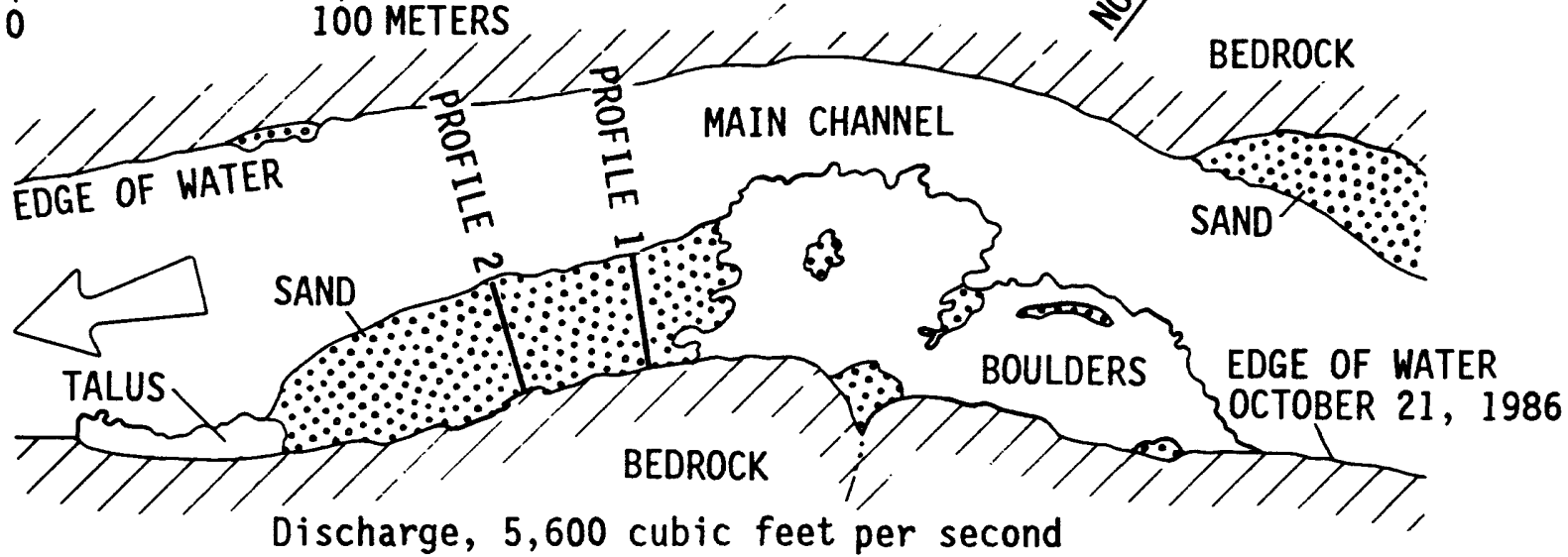

Figure 34.--Surficial geology and topography along two profiles at Twenty-Nine Mile Rapid. 
Table 14.--Areas of exposed sand at detailed study sites, 1965, 1973, and 1984

[Area is in thousands of square feet]

\begin{tabular}{|c|c|c|c|c|c|c|c|c|c|c|}
\hline \multirow{3}{*}{ Site $^{2}$} & \multirow{3}{*}{ Deposit 3} & \multirow{3}{*}{ Site name } & \multicolumn{5}{|c|}{ Area of exposed sand } & \multicolumn{3}{|c|}{ Change } \\
\hline & & & \multicolumn{3}{|c|}{$\begin{array}{c}\text { High } \\
\text { elevation }\end{array}$} & \multicolumn{2}{|c|}{$\begin{array}{l}\text { Low } \\
\text { elevation } 5\end{array}$} & \multicolumn{2}{|c|}{$\begin{array}{c}\text { High } \\
\text { elevation }\end{array}$} & \multirow{2}{*}{$\begin{array}{c}\begin{array}{c}\text { Low } \\
\text { elevation }\end{array} \\
41973-85\end{array}$} \\
\hline & & & 1965 & 1973 & 1984 & 1973 & 1984 & $1965-73$ & $1973-84$ & \\
\hline $2.5 \mathrm{~L}$ & $\mathbf{R}$ & $\begin{array}{l}\text { Above Cathedral } \\
\text { Wash }\end{array}$ & 35 & 18 & 17 & 64 & 59 & - & NC & NC \\
\hline $7.9 \mathrm{~L}$ & $\begin{array}{l}\mathbf{S} \\
\mathbf{R}\end{array}$ & $\begin{array}{l}\text { Badger Creek Rapid } \\
\text { Badger Creek Rapid }\end{array}$ & $\begin{array}{l}43 \\
7.9\end{array}$ & $\begin{array}{r}35 \\
0\end{array}$ & $\begin{array}{r}29 \\
0\end{array}$ & $\begin{array}{l}42 \\
17\end{array}$ & $\begin{array}{r}55 \\
0\end{array}$ & $\begin{array}{l}- \\
-\end{array}$ & NC & $\begin{array}{l}+ \\
-\end{array}$ \\
\hline $11.4 \mathrm{R}$ & $\mathbf{s}$ & Soap Creek Rapid & 85 & 86 & 90 & 110 & 99 & NC & NC & NC \\
\hline $12.2 \mathrm{~L}$ & $\mathbf{s}$ & $\begin{array}{l}\text { Below Salt Water } \\
\text { Wash }\end{array}$ & 17 & 10 & 17 & 31 & 35 & - & + & - \\
\hline $18.1 \mathrm{~L}$ & $\mathbf{s}$ & Eighteen Mile Wash & 11 & 4.0 & 6.9 & 15 & 15 & - & + & NC \\
\hline $19.0 \mathrm{~L}$ & $\mathbf{R}$ & $\begin{array}{l}\text { Opposite Nineteen } \\
\text { Mile Canyon }\end{array}$ & 29 & 16 & 14 & 57 & 25 & - & NC & - \\
\hline $19.8 \mathrm{~L}$ & $\mathbf{s}$ & Twenty Mile Camp & 21 & 20 & 21 & 33 & 30 & NC & NC & NC \\
\hline $29.2 \mathrm{~L}$ & $\mathbf{s}$ & $\begin{array}{l}\text { Twenty-Nine Mile } \\
\text { Rapid }\end{array}$ & 23 & 19 & 25 & 51 & 53 & - & + & NC \\
\hline 34.72 & $\begin{array}{l}\mathbf{S} \\
\mathbf{R}\end{array}$ & $\begin{array}{l}\text { Nautiloid Canyon } \\
\text { Nautiloid Canyon }\end{array}$ & $\begin{array}{r}34 \\
0\end{array}$ & $\begin{array}{r}30 \\
0\end{array}$ & $\begin{array}{r}18 \\
0\end{array}$ & $\begin{array}{l}41 \\
32\end{array}$ & $\begin{array}{l}33 \\
66\end{array}$ & NC & $\stackrel{+}{\mathrm{NC}}$ & + \\
\hline $44.2 \mathrm{~L}$ & s & $\begin{array}{l}\text { Eminence Break } \\
\text { Camp }\end{array}$ & 62 & 81 & 76 & 100 & 92 & + & NC & NC \\
\hline & $\mathbf{R}$ & $\begin{array}{l}\text { Eminence Break } \\
\text { Camp }\end{array}$ & 17 & 13 & 3.5 & 63 & 43 & - & - & - \\
\hline $93.4 \mathrm{~L}$ & $\mathbf{s}$ & Granite Rapid & 5 & 0 & 6.1 & NA & NA & - & + & NA \\
\hline $96.6 \mathrm{~L}$ & s & Boucher Rapid & 22 & 23 & 27 & NA & NA & NC & + & NA \\
\hline $168.0 R$ & $\begin{array}{l}\mathbf{S} \\
\mathbf{R}\end{array}$ & $\begin{array}{l}\text { Fern Glen Rapid } \\
\text { Fern Glen Rapid }\end{array}$ & $\begin{array}{l}97 \\
5.0\end{array}$ & $\begin{array}{r}54 \\
0\end{array}$ & $\begin{array}{r}70 \\
0\end{array}$ & $\begin{array}{l}95 \\
19\end{array}$ & $\begin{array}{r}100 \\
12\end{array}$ & - & $\stackrel{+}{\text { NC }}$ & NC \\
\hline
\end{tabular}

NC, no change; minus sign, loss of area; plus sign, gain in area; NA, not applicable.

River mile. $L$, left side of river; $R$, right side of river.

$R$, reattachment; $S$, separation.

Area exposed at discharge of about 25,000 cubic feet per second.

Area exposed at discharge of about 6,000 cubic feet per second. 
Aggradation and degradation occurred throughout the river corridor between 1983 and 1986. At some campsites, vertical aggradation of several feet occurred. Analysis of change in sand storage in all recirculation zones, however, shows that the number of reattachment deposits decreased 10 to 25 percent in the narrow reaches of Supai Gorge, Redwall Gorge, and Upper Granite Gorge (table 9). In Supai Gorge, major reattachment deposits also significantly decreased in area (table 10). In Muav Gorge, separation deposits inventoried as campsites decreased in area. In contrast, the number of deposits possibly increased in the wide reaches of Lower Marble Canyon and Furnace Flats (table 9). Area changes in these same reaches were not determined.

Separation deposits were more stable than other types of deposits. Analysis of volume changes at Eighteen Mile Wash shows that vertical aggradation can occur without change in area exposed at low flow. Erosion of separation deposits in Muav Gorge probably is related to low-elevation debris fans in this reach (table 10). Reattachment deposits are more susceptible to change during high flow as indicated by the percentage of deposits that have changed in number (table 9 ) or area (table 11).

The response of channel-margin deposits is uncertain. Only in Muav Gorge was a significant change in total area measured. More than 50 percent of deposits increased in area. Classification of study sites evaluated by Beus and others (1985) suggests that small channel-margin deposits in narrow reaches were eroded, although vertical aggradation occurred at other sites.

These results indicate less change in major deposits due to high discharge in 1983-84 than that reported by Brian and Thomas (1984). Brian and Thomas (1984) inventoried campsites after recession of high flows in 1983 and recognized many new or enlarged alluvial sand deposits. They also reported that about 10 percent of the pre-existing campsites had been significantly eroded. Their inventory however was made at a discharge of about $25,000 \mathrm{ft}^{3} / \mathrm{s}$. The difference in results suggest that changes in high-elevation parts of alluvial deposits were more significant than changes in low-elevation parts.

Changes in area of high- and low-elevation parts of alluvial sand deposits were determined to evaluate topographic changes above and below an approximate stage corresponding to a discharge of $25,000 \mathrm{ft}^{3} / \mathrm{s}$ (table 14). At most sites, the area of the high-elevation part of the deposit above this stage increased or did not change between 1973 and 1984, whereas the low-elevation part typically decreased in size or did not change. These results show that although high-elevation parts of deposits aggraded, and that low-elevation parts either degraded or did not change. Patterns of change determined for high-elevation parts are not necessarily consistent with changes in low-elevation parts.

The onset of strongly fluctuating flows in October 1985 caused widespread erosion, especially in narrow reaches. Erosion of separation deposits occurred at sites as far as $167 \mathrm{mi}$ downstream from Lees Ferry 
(fig. 33). Erosion was typically of the sand that had been deposited in 1983-85. Comparison of table 14 with figure 33 indicates that sites that eroded significantly between October 1985 and January 1986 al so had eroded significantly from 1965 to 1973 and then had aggraded significantly during the 1983 high flows. For example, at Eighteen Mile Wash, Twenty-Nine Mile Rapid, and Fern Glen Rapid, significant erosion was measured between October 1985 and January 1986. These sites had eroded significantly between 1965 and 1973 and aggraded in 1983. Significant aggradation was not followed by significant degradation in narrow reaches where a high separation deposit was armored from further erosion by exposed debris-fan deposits, as at Nautiloid Canyon.

The high flows of 1983 and 1984, therefore, redistributed much sand and removed sand from 10 to 25 percent of recirculation zones in at least those narrow reaches within $160 \mathrm{mi}$ of Lees Ferry. Significant aggradation however occurred at many major campsites. Aggradation may have occurred in recirculation zones in wide reaches. Many new alluvial sand deposits eroded rapidly when exposed to strongly fluctuating discharges, which suggests that most of the gain in sand resulting from high flows was of short duration.

\section{SUMMARY}

This report has presented a classification of alluvial sand deposits, described some characteristics of these deposits, and described changes that have occurred in these deposits since completion of Glen Canyon Dam. The classification of alluvial sand deposits and the designation of reaches within Grand Canyon were used to distinguish styles of change in narrow and wide reaches. Measurement of topographic changes in alluvial deposits were based on topographic and bathymetric surveys and analysis of aerial photographs.

The largest and most numerous alluvial sand deposits along the Colorado River in Grand Canyon National Park are formed in zones of recirculating current. Recirculation zones are caused by large debris fans that partially block the channel and by minor bedrock or talus abutments. Alluvial sand deposits can be classified by form and location. Separation deposits are located near the point of flow separation, mantle debris fans, and extend to the edge of the primary-eddy return-current channel. Reattachment deposits are located near the point of flow reattachment and project upstream beneath the primary eddy. Channel-margin deposits are terracelike in form and may fill re-entrants or extend continuously along the channel in wide reaches for lengths of $1 \mathrm{mi}$. Channel-margin deposits probably are formed in recirculation zones.

The Colorado River corridor in Grand Canyon National Park was divided into eleven reaches. Separation deposits large enough to be used as campsites are common throughout the river corridor in narrow and wide reaches. Reattachment and channel-margin deposits large enough to be used as campsites are common only in wide reaches except in the Muav Gorge where channel-margin deposits are common. 
The form and sedimentology of alluvial sand deposits reflect the hydraulic and sediment-transport conditions existing during reworking and deposition of the deposit. Separation deposits form in lower velocity parts of the river than reattachment deposits and may be composed of slightly finer sand. At sufficiently high discharge, both separation and reattachment deposits are reworked, and sand is redistributed within the recirculation zone and between the recirculation zone and the main channel. This response to high flow is documented by repeated topographic surveys and sedimentologic analysis of study sites Above Cathedral Wash, at Eighteen Mile Wash, and Opposite Nineteen Mile Canyon and by repeated bathymetric mapping at Eminence Break Camp, Blacktail Rapid, and National Rapid.

During recession from high flows, redistribution of sand within recirculation zones may result in degradation of the deposit. The high flows of 1983 and 1984 removed sand from recirculation zones in narrow reaches within $118 \mathrm{mi}$ of Lees Ferry. When the rate of recession is great enough, topographic conditions at some sites cause flow to be directed away from a sand deposit and leave it exposed, such as at Eighteen Mile Wash. At other sites, especially reattachment deposits, redistribution of sand may continue even during a rapid recession. At many reattachment deposits, the result is erosion of downstream areas and loss of sand to the main channel and redistribution of sand in other parts of the deposit within the recirculation zone. Higher rates of recession allow less time for this distribution and therefore may result in exposure of larger areas of alluvial sand deposits after recession at some sites.

Fluctuating flows following high steady flows during the study period resulted in significant erosion. Fluctuating flows typically redistributed sand within recirculation zones and may deposit sand along the slope from the reattachment-deposit crest to the thaiweg. Although erosion was significant throughout the park with the onset of fluctuating flow, results of topographic surveys by other investigators in the late 1970's indicate that equilibrium was reached after a period of years. Topographic surveys between October 1985 and January 1986 indicate that such stability was not reached within 3-1/2 months of strongly fluctuating flow. Redistribution of sand can affect significant parts of alluvial sand deposits.

Bathymetric surveying at three sites show that net volume changes can occur in recirculation zones at a broad range of discharges. At each site, net volume changes indicate that large volumes of sand may be exchanged between recirculation zones and the main channel even at moderate or fluctuating discharges.

The high flows of 1983 and 1984 eroded sand from recirculation zones in narrow reaches. The high flows may have resulted in aggradation of all types of alluvial sand deposits in wide reaches. Limited evidence suggests that high flows in 1985 caused further erosion of reattachment deposits in narrow reaches.

Alluvial sand deposits used as campsites, whatever their type, are more stable than the smaller, lower-elevation deposits of the same type not used as campsites. Many campsites aggraded significantly during 
high flows in 1983. Fluctuating flows in 1985 and 1986 caused rapid erosion of many deposits of all types throughout the Grand Canyon. The greatest erosion typically occurred at sites where significant deposition had occurred in 1983. The increase in sand at campsites from high flow therefore is of limited duration if strongly fluctuating flows follow. During these same high flows, sand was removed from other recirculation zones in narrow reaches. Separation deposits are more stable than reattachment deposits, although erosion can occur in reaches where separation deposits are of low elevation such as Muav Gorge. An inventory of campsites in 1983 showed that narrow reaches generally have few campsites. The high flows of 1983-85 followed by strongly fluctuating flows in 1985 resulted in accentuating the difference between campsite availability in narrow and wide reaches.

\section{REFERENCES CITED}

Anderson, T.W., and White, N.D., 1979, Statistical summaries of Arizona streamflow data: U.S. Geological Survey Water-Resources Investigations $79-5,416 \mathrm{p}$.

Beus, S.S., Carothers, S.W., Avery, C.C., 1985, Topographic changes in fluvial terrace deposits used as campsite beaches along the Colorado River in Grand Canyon: Journal of the Arizona-Nevada Academy of Science, v. 20, p. 111-120.

Birdseye, C.H., 1923, Plan and profile of Colorado River from Lees Ferry, Arizona to Black Canyon, Arizona-Nevada: U.S. Geological Survey topographic maps, 21 sheets, scale 1:31,680.

Brian, N.J., and Thomas, J.R., 1984, 1983 Colorado River beach campsite inventory, Grand Canyon National Park, Arizona: Division of Resources Management, Grand Canyon National Park report, $56 \mathrm{p}$.

Burkham, D.E., 1986, Trends in selected hydraulic variables for the Colorado River at Lees Ferry and near Grand Canyon, Arizona, 1922-84: U.S. Bureau of Reclamation, Glen Canyon Environmental Studies Report, $51 \mathrm{p}$.

Dolan, Robert, Howard, Al an, and Gallenson, Arthur, 1974, Man's impact on the Colorado River in the Grand Canyon: American Scientist, v. 62, p. $393-401$.

Ferrari, Ronald, 1987, Sandy beach area survey along the Colorado River in the Grand Canyon National Park: U.S. Bureau of Reclamation, Glen Canyon Environmental Studies Report, 23 p.

Folk, R.L., 1968, Petrology of sedimentary rocks: Austin, Texas, Hemphili's, 170 p.

Graf, J.B., 1986, Sediment transport under regulated flow, Colorado River, Grand Canyon National Park, Arizona: EOS, Transactions, American Geophysical Union, v. 67, no. 44, p. 950. 
Grand Canyon Natural History Association, 1976, Geologic map of the Grand Canyon National Park, Arizona: Grand Canyon, Arizona, Grand Canyon Natural History Association, scale 1:62,500.

Helley, E.J., and Smith, W., 1971, Development and calibration of a pressure-difference bedioad sampler: U.S. Geological Survey open-file report, $18 \mathrm{p}$.

Howard, A.D., 1975, Establishment of benchmark study sites along the Colorado River in Grand Canyon National Park for monitoring of beach erosion caused by natural forces and human impact: University of Virginia Grand Canyon Study, Technical Report no. $1,182 \mathrm{p}$.

Howard, A.D., and Dolan, Robert, 1979, Changes in the fluvial deposits of the Colorado River in the Grand Canyon caused by Glen Canyon Dam, in Lin, R.M., ed., First Conference on Scientific Research in the National Parks, v. 2, New Orleans, Louisiana, November 9-12, 1976, Proceedings: National Park Service Transactions and Proceedings Series, no. 5, p. 845-851.

1981, Geomorphology of the Colorado River in the Grand Canyon: Journal of Geology, v. 89, no. 3, p. 269-298.

Hunter, R.E., 1977, Terminology of cross-stratified sedimentary layers and climbing-ripple structures: Journal of Sedimentary Petrology, v. 47 , no. 2, p. 697-706.

Kieffer, S.W., 1985, The 1983 hydraulic jump in Crystal RapidImplications for river-running and geomorphic evolution in the Grand Canyon: Journal of Geology, v. 93, no. 4, p. 385-406.

Laursen, E.M., and Silverston, E., 1976, Camera stations along the Colorado River through the Grand Canyon-Supplement to the final report on the hydrology and sedimentology of the Colorado River: Division of Resource Management, Grand Canyon National Park, 150 p. [Unpublished report to the National Park Service.]

Laursen, E.M., Ince, Simon, and Pollack, Jack, 1976, On sediment transport through Grand Canyon: Third Federal Interagency Sedimentation Conference Proceedings, p. 4-76 to 4-87.

Leopold, L.B., 1969, The rapids and the pools-Grand Canyon, in The Colorado River Region and John Wesley Powell: U.S. Geological Survey Professional Paper 669, p. 131-145.

Lojko, F.B., 1985, Beach sand grain size on the Colorado River in the Grand Canyon, in House, D.A., ed., Colorado River Investigations III, Flagstaff, Arizona, Northern Arizona University, p. 85-93.

Matthes, G.H., 1947, Macroturbulence in natural streamflow: Transactions, of the American Geophysical Union, v. 28, no. 2, p. 255-262. 
Orvis, C.J., and Randle, T.J., 1986, Sediment transport and river simulation model: Fourth Federal Interagency Sedimentation Conference, v. 2, Las Vegas, Nevada, March 24-27, 1986, Proceedings, p. 6-65 to 6-74.

Pemberton, E.L., and Randle, T.J., 1986, Colorado River sediment transport in Grand Canyon: Fourth Federal Interagency Sedimentation Conference, v. 2, Las Vegas, Nevada, March 24-27, 1986, Proceedings, p. 4-120 to 4-130.

Randle, T.J., and Pemberton, E.L., 1987, Results and analys is of STARS modeling efforts of the Colorado River in Grand Canyon: U.S. Bureau of Reclamation, Glen Canyon Environmental Studies Report, $41 \mathrm{p}$.

Schmidt, J.C., 1986, Controls on flow separation and sedimentation in a bedrock river, Colorado River, Grand Canyon, Arizona: Geological Society of America, Abstracts with Programs, v. 18, p. 741 .

Turner, R.M., and Karpiscak, M.M., 1980, Recent vegetation changes along the Colorado River between Glen Canyon Dam and Lake Mead, Arizona: U.S. Geological Survey Professional Paper 1132, $125 \mathrm{p}$.

Webb, R.H., Pringle, P.T., and Rink, G.R., 1987, Debris flows in tributaries of the Colorado River, Grand Canyon National Park, Arizona: U.S. Geological Survey Open-File Report 87-118, 64 p.

Wilson, R.P., 1986, Sonar patterns of Colorado riverbed, Grand Canyon: Fourth Federal Interagency Sedimentation Conference, $v .2$, Las Vegas, Nevada, March 24-27, 1986, Proceedings, p. 5-133 to 5-142. 
page 113 follows

111

APPENDIX A

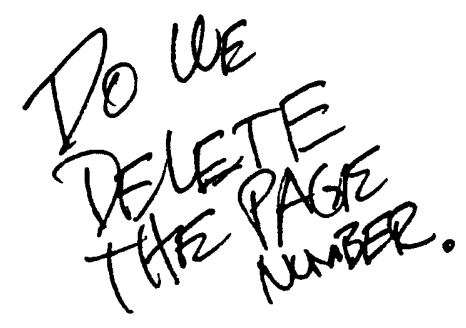


Comparison of river mile inventories of 1973 and 1983 from Lees Ferry to Stone Creek

\begin{tabular}{|c|c|c|c|c|c|c|}
\hline \multirow{2}{*}{$\begin{array}{l}\begin{array}{l}\text { River mile } \\
\text { inventory }\end{array} \\
1923^{1}\end{array}$} & \multirow{2}{*}{$\begin{array}{l}\text { Side } \\
\text { of } \\
\text { river }\end{array}$} & \multirow[t]{2}{*}{ Site } & \multirow{2}{*}{$\begin{array}{l}\text { Aerial } \\
\text { photo- } \\
\text { graph } \\
\text { number } 2\end{array}$} & \multicolumn{2}{|c|}{$\begin{array}{l}\text { River mile } \\
\text { inventory }\end{array}$} & \multirow{2}{*}{$\begin{array}{l}\text { Deposit } \\
\text { type } 3\end{array}$} \\
\hline & & & & 1973 & 1983 & \\
\hline 0.0 & ----- & Lees Ferry & ---- & $-\ldots$ & ---- & ----------- \\
\hline 1.9 & Left & Unnamed site & $1-141$ & 1.9 & 2.0 & Point bar \\
\hline 2.5 & Left & Above Cathedral Wash & $1-144$ & $-\cdots$ & --- & Reattachment \\
\hline 2.7 & Right & Cathedral Wash & $1-145$ & 2.7 & 3.0 & Separation \\
\hline 5.7 & Right & Six Mile Wash & $1-173$ & 5.8 & ---- & Separation \\
\hline 7.9 & Right & Badger Creek Rapid & $1-193$ & 7.9 & 8.0 & Separation \\
\hline 7.9 & Left & Badger Creek Rapid & $1-193$ & 7.9 & 8.0 & Separation \\
\hline 10.3 & Left & Below Ten Mile Rock & $1-211$ & ---- & 10.2 & Reattachment \\
\hline 11.4 & Right & Soap Creek Rapid & $1-219$ &.--- & 11.5 & Separation \\
\hline 12.0 & Left & Salt Water Wash & $1-223$ & ---- & 12.0 & Separation \\
\hline 12.2 & Left & Below Salt Water Wash & $1-226$ & 12.2 & 12.4 & Separation \\
\hline 16.5 & Left & Hot Na Na Wash & $2-3$ & 16.5 & 16.5 & Separation \\
\hline 17.0 & Right & House Rock Rapid & $2-6$ & 17.1 & ---- & Separation \\
\hline 18.1 & Left & Eighteen Mile Wash & $2-15$ & 18.2 & 18.2 & Separation \\
\hline 18.9 & Right & Nineteen Mile Canyon & $2-21$ & ---- & 19.0 & Upper pool \\
\hline 19.0 & Left & $\begin{array}{l}\text { Opposite Nineteen Mile } \\
\text { Canyon }\end{array}$ & $2-22$ & 19.3 & 19.2 & Reattachment \\
\hline 19.8 & Left & Twenty Mile Camp & $2-28$ & 20.0 & 20.0 & Separation \\
\hline 20.2 & Left & Unnamed site & $2-29$ & 20.2 & ---- & Separation \\
\hline 20.3 & Right & $\begin{array}{l}\text { Above North Canyon } \\
\text { Rapid }\end{array}$ & $2-32$ & ---- & 20.5 & Upper pool \\
\hline 20.4 & Right & North Canyon Rapid & $2-32$ & ---- & 20.5 & Separation \\
\hline 21.3 & Left & Twenty-Two Mile Wash & $2-38$ & 21.5 & 21.5 & Separation \\
\hline 21.6 & Left & Unnamed site & $2-40$ & 21.5 & 21.5 & Separation \\
\hline 21.7 & Right & Unnamed site & $2-41$ & 21.8 & $\cdots$ & Reattachment \\
\hline 22.5 & Left & Unnamed site & $2-45$ & 22.3 & 22.8 & Separation \\
\hline 22.7 & Right & $\begin{array}{l}\text { Above Indian Dick } \\
\text { Rapid }\end{array}$ & $2-47$ & 22.6 & 22.7 & Separation \\
\hline 23.4 & Left & $\begin{array}{l}\text { Twenty-Three and One- } \\
\text { Half Mile Rapid }\end{array}$ & $2-50$ & 23.2 & ---- & Separation \\
\hline 24.5 & Left & $\begin{array}{l}\text { Above Twenty-Four and } \\
\text { One-Half Mile Rapid }\end{array}$ & $2-57$ & ---- & 24.5 & Upper pool \\
\hline 24.8 & Left & $\begin{array}{l}\text { Twenty-Four and One- } \\
\text { Half Mile Rapid }\end{array}$ & $2-58$ & - & 24.7 & Separation \\
\hline 25.0 & Left & Twenty-Five Mile Rapid & $2-60$ & 24.9 & - & $\begin{array}{l}\text { Reattachment; } \\
\text { upper pool }\end{array}$ \\
\hline 26.2 & Left & Unnamed site & $2-68$ & 26.2 & ---- & Separation \\
\hline 26.4 & Left & Above Tiger Wash Rapid & $2-70$ & ----- & 26.5 & Separation \\
\hline 26.7 & Left & Tiger Wash Rapid & $2-72$ & 26.7 & ---- & Separation \\
\hline 28.7 & Right & Unnamed site & $2-86$ & 28.8 & ---- & Separation \\
\hline 28.9 & Right & Unnamed site & $2-86$ & 29.0 & ---- & $\begin{array}{l}\text { Separation; } \\
\text { reattachment }\end{array}$ \\
\hline 29.2 & Left & Twenty-Nine Mile Rapid & $2-87$ & 29.2 & 29.3 & Separation \\
\hline 30.3 & Right & Unnamed site & $2-94$ & 30.3 & 30.3 & $\begin{array}{l}\text { Reattachment; } \\
\text { upper pool }\end{array}$ \\
\hline 30.4 & Right & Unnamed & $2-95$ & ---- & 30.4 & Reattachment \\
\hline 31.5 & Right & South Canyon & $2-102$ & 31.5 & 31.5 & Separation \\
\hline 33.5 & Left & Little Redwall Camp & $2-114$ & 33.5 & 33.7 & Separation \\
\hline 33.7 & Left & Unnamed site & $2-116$ & 33.9 & 33.8 & Separation \\
\hline 34.7 & Left & Naut1loid Canyon & $2-123$ & 34.7 & 34.8 & Separation \\
\hline 35.1 & Left & Unnamed site & $2-132$ & 35.1 & ---- & Separation \\
\hline 36.0 & Left & Thirty-Six Mile Rapid & $2-138$ & 36.0 & ---- & Separation \\
\hline 37.2 & Right & Unnamed site & $2-147$ & 37.2 & ---- & Reattachment; \\
\hline 37.3 & Left & Tatahatso Wash & $2-148$ & 37.3 & --- & Upper pool \\
\hline 37.6 & Left & Below Tatahatso Wash & $2-150$ & 37.6 & 37.5 & Upper pool \\
\hline 38.0 & Left & Unnamed site & $2-154$ & ---- & 38.4 & $\begin{array}{l}\text { Separation; } \\
\text { reattachment }\end{array}$ \\
\hline
\end{tabular}


Comparison of river mile inventories of 1973 and 1983 from Lees Ferry to Stone Creek--Continued

\begin{tabular}{|c|c|c|c|c|c|c|}
\hline \multirow{2}{*}{$\begin{array}{c}\begin{array}{c}\text { River mile } \\
\text { inventory }\end{array} \\
1923^{1}\end{array}$} & \multirow{2}{*}{$\begin{array}{l}\text { Side } \\
\text { of } \\
\text { river }\end{array}$} & \multirow[t]{2}{*}{ Site } & \multirow{2}{*}{$\begin{array}{l}\text { Aerial } \\
\text { photo- } \\
\text { graph } \\
\text { number } 2\end{array}$} & \multicolumn{2}{|c|}{$\begin{array}{l}\text { River mile } \\
\text { inventory }\end{array}$} & \multirow{2}{*}{$\begin{array}{l}\text { Deposit } \\
\text { type } 3\end{array}$} \\
\hline & & & & 1973 & 1983 & \\
\hline 38.5 & Left & Unnamed site & $2-157$ & 38.6 & 38.8 & $\begin{array}{l}\text { Chamel margin; } \\
\text { reattachment }\end{array}$ \\
\hline 39.9 & Left & Unnamed site & $2-166$ & 39.8 & --- & Separation \\
\hline 40.2 & Left & Unnamed site & $2-168$ & 40.1 & ---- & Channel margin; \\
\hline 40.9 & Right & Upper Buckfarm Canyon & $2-173$ & 40.9 & 40.9 & $\begin{array}{l}\text { Reattachment; } \\
\text { upper pool }\end{array}$ \\
\hline 41.0 & Right & Lower Buckfarm Canyon & $2-173$ & 41.0 & 41.0 & Separation \\
\hline 41.3 & Right & Bert Loper Canyon & $2-205$ & 41.3 & $\cdots$ & Separation \\
\hline 41.5 & Right & Royal Arches & $2-206$ & 41.5 & $-\cdots$ & Reattachment \\
\hline 42.0 & Left & Unnamed site & $2-177$ & 41.9 & $-\cdots$ & Channel margin \\
\hline 42.2 & Left & Unnamed site & $2-178$ & 42.1 & 42.3 & Chamel margin \\
\hline 42.8 & Left & Unnemed site & $2-181$ & --- & 42.9 & Channel margin \\
\hline 43.1 & Left & Unnamed site & $2-183$ & 43.2 & $\cdots$ & Separation; \\
\hline 43.5 & Left & President Harding Rapid & $2-184$ & 43.4 & 43.3 & Separation \\
\hline 44.2 & Left & Eminence Break Camp & $2-187$ & 44.2 & $\cdots-$ & Separation \\
\hline 44.6 & Left & Unnamed site & $2-191$ & 44.5 & 44.6 & Separation \\
\hline 44.8 & Left & Unnemed site & $2-192$ & 44.7 & 44.8 & $\begin{array}{l}\text { Reattachment; } \\
\text { upper pool }\end{array}$ \\
\hline 44.9 & Left & Unnamed site & $2-193$ & 45.0 & $-\cdots$ & Separation \\
\hline 45.3 & Right & $\begin{array}{l}\text { Above Triple Alcoves } \\
\text { Camp }\end{array}$ & $2-195$ & $-\cdots$ & 45.3 & $\begin{array}{l}\text { Channel margin; } \\
\text { reattachment }\end{array}$ \\
\hline 45.9 & Left & Unnamed site & $2-198$ & 45.8 & 46.0 & Upper pool \\
\hline 46.7 & Right & Triple Alcoves & $2-203$ & 46.8 & 46.5 & $\begin{array}{l}\text { Reattachment; } \\
\text { upper pool }\end{array}$ \\
\hline 46.8 & Right & Unnemed site & $2-204$ & Marsh & Marsh & Reattachment \\
\hline 47.0 & Right & $\begin{array}{l}\text { Lower Triple Alcoves } \\
\text { Camp }\end{array}$ & $2-211$ & $\cdots$ & 46.6 & Separation \\
\hline 47.2 & Right & Saddile Canyon & $2-213$ & 47.1 & 47.2 & Separation \\
\hline 47.3 & Right & Below Saddle Canyon & $2-214$ & $\cdots$ & 47.3 & Reattachment \\
\hline 47.5 & Left & Unnamed site & $2-215$ & $\ldots-$ & 47.5 & Separation \\
\hline 47.5 & Right & Unnemed site & $2-215$ & $-\cdots$ & 47.8 & $\begin{array}{l}\text { Separation; } \\
\text { reattachment }\end{array}$ \\
\hline 47.7 & Left & Unnemed site & $2-216$ & $\ldots-$ & 47.8 & Reattachment \\
\hline 48.0 & Left & Unnaned site & $2-217$ & $\ldots-$ & 48.0 & Reattachment \\
\hline 48.3 & Right & Unnamed site & $2-219$ & 48.3 & $-\cdots$ & $\begin{array}{l}\text { Reattachment; } \\
\text { upper pool }\end{array}$ \\
\hline 49.5 & Left & Unnamed site & $2-225$ & $-\cdots$ & 49.7 & $\begin{array}{l}\text { Reattachment; } \\
\text { upper pool }\end{array}$ \\
\hline 49.8 & Left & Unnamed site & $2-226$ & 49.5 & 49.9 & $\begin{array}{l}\text { Reattachment; } \\
\text { separation }\end{array}$ \\
\hline 49.8 & Right & Fifty Mile Camp & $2-227$ & $\ldots$ & 49.9 & Upper pool \\
\hline 49.9 & Right & Dinosaur Camp & $2-227$ & 50.0 & 50.0 & Separation \\
\hline 50.3 & Left & Unnamed site & $2-229$ & $\ldots$ & 50.2 & $\begin{array}{l}\text { Chamnel margin; } \\
\text { reattachment }\end{array}$ \\
\hline 50.7 & Left & Unnamed site & $2-232$ & 50.6 & 50.6 & Reattachmet \\
\hline 51.1 & Right & Unnamed site & $2-235$ & $\cdots-$ & 51.0 & Separation \\
\hline 51.2 & Left & Unnemed site & $2-236$ & Marsh & 51.5 & Reattachment \\
\hline 51.3 & Right & Unnamed site & $2-236$ & --- & 51.4 & Reattachment \\
\hline 51.5 & Left & Unnamed site & $2-237$ & Marsh & $-\cdots$ & Reattachment \\
\hline 51.9 & Right & Little Nankoweap Creek & $3-1$ & 51.9 & 51.8 & $\begin{array}{l}\text { Reattachment; } \\
\text { upper pool }\end{array}$ \\
\hline 52.1 & Right & Unnamed site & $3-2$ & 52.0 & --- & Separation \\
\hline 52.3 & Right & Above Nankoweap Rapid & $3-3$ & $-\cdots$ & 52.3 & Channel margin \\
\hline 52.5 & Right & Nankoweap Rapid & $3-4$ & 52.5 & 52.5 & Channel margin \\
\hline 53.0 & Right & Nankoweap Rapid & $3-7$ & -- & 52.7 & $\begin{array}{l}\text { Channel margin; } \\
\text { reattachment }\end{array}$ \\
\hline
\end{tabular}

See footnotes at end of table. 
APPENDIX A

Comparison of river mile inventories of 1973 and 1983 from Lees Ferry to Stone Creek--Continued

\begin{tabular}{|c|c|c|c|c|c|c|}
\hline $\begin{array}{l}\text { River mile } \\
\text { inventory }\end{array}$ & Side & Site & $\begin{array}{l}\text { Aerial } \\
\text { photo- }\end{array}$ & $\begin{array}{l}\text { River } \\
\text { Inven }\end{array}$ & $\begin{array}{l}\text { mile } \\
\text { orr }\end{array}$ & Deposit \\
\hline $1923^{1}$ & river & & number ${ }^{2}$ & 1973 & 1883 & \\
\hline 53.2 & Right & Below Nankoweap Rapid & $3-8$ & 53.0 & 53.0 & $\begin{array}{l}\text { Channel margin; } \\
\text { reattachment }\end{array}$ \\
\hline 53.2 & Left & Unnamed site & $3-8,10$ & 53.1 & 53.0 & Point bar \\
\hline 53.4 & Right & Below Nankoweap Rapid & $3-10$ & ---- & 53.2 & Separation \\
\hline 53.7 & Left & Unnamed site & $3-12$ & 53.3 & 53.4 & $\begin{array}{l}\text { Channel margin; } \\
\text { reattachment }\end{array}$ \\
\hline 53.7 & Right & Unnamed site & $3-12$ & 53.6 & 53.4 & Separation \\
\hline 53.8 & Right & Unnamed site & $3-13$ & 53.7 & ----- & $\begin{array}{l}\text { Chamel margin; } \\
\text { reattachment }\end{array}$ \\
\hline 53.8 & Left & Unnamed site & $3-13$ & 53.8 & 53.8 & Channel margin \\
\hline 54.1 & Left & Unnamed site & $3-14$ & ---- & 54.0 & Separation \\
\hline 54.2 & Right & Unnamed site & $3-15$ & ---- & 54.0 & Separation \\
\hline 54.3 & Right & Unnamed site & $3-16$ & 54.2 & 54.2 & $\begin{array}{l}\text { Reattachment; } \\
\text { upper pool }\end{array}$ \\
\hline 54.4 & Right & Unnamed site & $3-17$ & 54.5 & ----- & Reattachment \\
\hline 54.5 & Left & Unnamed site & $3-17$ & Marsh & 54.4 & Upper pool \\
\hline 54.6 & Left & Unnamed site & $3-18$ & ----- & 54.6 & Channel margin \\
\hline 54.7 & Left & Unnamed site & $3-18$ & ---- & 54.7 & Reattachment \\
\hline 55.0 & Left & Unnamed site & $3-21$ & ----- & 55.0 & $\begin{array}{l}\text { Upper pool; } \\
\text { reattachment }\end{array}$ \\
\hline 55.1 & Left & Unnamed site & $3-21$ & ----- & 55.2 & Separation \\
\hline 55.3 & Left & Unnamed site & $3-22$ & Marsh & 55.4 & Reattachment \\
\hline 55.6 & Right & Unnamed site & $3-24$ & Marsh & ----- & Reattachment \\
\hline 56.3 & Right & Kwagunt Rapid & ----- & ----- & 56.2 & Reattachment \\
\hline 56.4 & Right & Below Kwagunt Rapid & $---\infty$ & ----- & 56.4 & Channel margin \\
\hline 56.5 & Right & Unnamed site & $3-28$ & 56.6 & 56.5 & $\begin{array}{l}\text { Chanmel margin; } \\
\text { reattachment }\end{array}$ \\
\hline 56.8 & Left & Unnamed site & $3-29$ & 56.8 & 56.8 & Channel margin \\
\hline 57.0 & Left & Unnamed site & $3-30$ & ----- & 57.0 & Separation \\
\hline 57.5 & Right & Malagosa Canyon & $3-33$ & 57.4 & 57.5 & Separation \\
\hline 57.6 & Left & Unnamed site & $3-34$ & 57.7 & 57.5 & Reattachment \\
\hline 58.2 & Right & Awatubi Canyon & $3-37$ & ----- & 58.2 & Separation \\
\hline 58.6 & Left & Unnemed site & $3-39$ & 58.5 & 58.7 & Separation \\
\hline 58.9 & Right & Unnamed site & $3-40$ & ----- & 58.5 & Upper pool \\
\hline 59.0 & Left & Unnamed site & $3-41$ & 58.0 & 59.0 & Reattachment; \\
\hline 59.5 & Right & Umamed site & $3-44$ & ---- & 59.5 & Channel margin \\
\hline 59.8 & Right & Sixty Mile Rapid & $3-45$ & ----- & 59.8 & Separation \\
\hline 60.2 & Left & Unnemed site & $3-48$ & ---- & 60.0 & $\begin{array}{l}\text { Reattachment; } \\
\text { upper pool }\end{array}$ \\
\hline 60.6 & Right & Unnamed site & $3-51$ & ---- & 60.5 & Separation \\
\hline 61.1 & Right & Unnamed site & $3-53$ & ---- & 61.2 & $\begin{array}{l}\text { Reattachwent; } \\
\text { upper pool }\end{array}$ \\
\hline 61.4 & Left & Island Camp & $3-56$ & ---- & 61.8 & $\begin{array}{l}\text { Separation; } \\
\text { reattachment }\end{array}$ \\
\hline 61.7 & Right & $\begin{array}{l}\text { Below Little Colorado } \\
\text { River confluence }\end{array}$ & $3-58$ & ----- & 61.8 & Separation \\
\hline 62.3 & Right & Unnamed site & $3-61$ & 62.4 & 62.3 & Upper pool \\
\hline 63.3 & Right & Unnemed site & $3-68$ & 63.3 & ---- & Separation \\
\hline 64.0 & Left & Unnamed site & $3-71$ & 63.9 & ----- & Reattachament \\
\hline 64.7 & Right & Carbon Creek & $3-75$ & 64.5 & 64.5 & Separation \\
\hline 65.4 & Right & Lava Canyon Rapid & $3-78$ & 65.5 & 65.5 & $\begin{array}{l}\text { Reattachment; } \\
\text { upper pool }\end{array}$ \\
\hline 65.6 & Left & Palisades Creek & $3-82$ & 65.5 & 65.6 & Separation \\
\hline 66.0 & Left & Unnamed site & $3-84$ & 66.1 & ----- & Chamel margin \\
\hline 66.4 & Left & Unnemed site & $3-86$ & 66.4 & 66.5 & $\begin{array}{l}\text { Reattachment; } \\
\text { channel margin }\end{array}$ \\
\hline
\end{tabular}


Comparison of river mile inventories of 1973 and 1983 from Lees Ferry to Stone Creek--Continued

\begin{tabular}{|c|c|c|c|c|c|c|}
\hline \multirow{2}{*}{$\begin{array}{l}\begin{array}{l}\text { River mile } \\
\text { inventory }\end{array} \\
{ }_{1923^{1}}\end{array}$} & \multirow{2}{*}{$\begin{array}{l}\text { Side } \\
\text { of } \\
\text { river }\end{array}$} & \multirow[t]{2}{*}{ Site } & \multirow{2}{*}{$\begin{array}{l}\text { Aerial } \\
\text { photo- } \\
\text { graph } \\
\text { number } 2\end{array}$} & \multicolumn{2}{|c|}{$\begin{array}{l}\text { River mile } \\
\text { inventory }\end{array}$} & \multirow{2}{*}{$\begin{array}{c}\text { Deposit } \\
\text { type }\end{array}$} \\
\hline & & & & 1973 & 1983 & \\
\hline 66.8 & Left & Espejo Creek & $3-90$ & 66.9 & 66.8 & $\begin{array}{l}\text { Chamel margin; } \\
\text { separation }\end{array}$ \\
\hline 67.3 & Left & Comanche Creek & $3-92$ & 67.3 & ---- & Chamel margin \\
\hline 67.7 & Left & Unnamed site & $3-94$ & 67.7 & ---- & Channel margin \\
\hline 67.8 & Right & Unnamed site & $3-94$ & ---- & 67.8 & Chamel margin \\
\hline 68.0 & Right & Upper Tanner & $3-96$ & 68.0 & 68.0 & Point bar \\
\hline 68.2 & Right & Unnamed site & $3-97$ & 68.1 & 68.2 & Point bar \\
\hline 68.6 & Left & Tanner & $3-101$ & 68.7 & 68.6 & Chamel margin \\
\hline 68.7 & Left & Tanner & $3-101$ & 68.8 & ---- & Point bar \\
\hline 69.3 & Left & Below Tanner & $3-111$ & 69.5 & 69.0 & Point bar \\
\hline 69.4 & Right & Upper Basalt Rapid & $3-112$ & 69.5 & 69.6 & Chamel margin \\
\hline 69.8 & Right & Lower Basalt Rapid & $3-113$ & ---- & 69.8 & Chamel margin \\
\hline 69.9 & Left & Unnamed site & $3-114$ & 69.9 & --- & Chamel margin \\
\hline 70.2 & Left & Unnamed site & $3-116$ & 70.2 & ---- & Chamel margin \\
\hline 70.3 & Right & Unnamed site & $3-117$ & ---- & 70.3 & Channel margin \\
\hline 70.5 & Right & Unnamed site & $3-117$ & ----- & 70.5 & Chamel margin \\
\hline 70.9 & Left & Unnamed site & $3-120$ & Marsh & ---- & $\begin{array}{l}\text { Chamel margin; } \\
\text { reat tachment }\end{array}$ \\
\hline 71.3 & Left & Cardenas Creek & $3-121$ & ----- & 71.3 & Separation \\
\hline 71.4 & Left & Unnamed site & $3-121$ & Marsh & --- & Reattachment \\
\hline 71.7 & Left & Unnamed site & $3-124$ & $---\infty$ & 71.7 & Chamel margin \\
\hline 71.9 & Right & Unnamed site & $3-126$ & ---- & $-\infty-\infty$ & Separation \\
\hline 72.1 & Left & Unnamed site & $3-128$ & 72.1 & 72.1 & Point bar \\
\hline 72.5 & Right & Above Unkar Rapid & $3-129$ & ---- & 72.5 & Chamel margin \\
\hline 72.6 & Right & Middle Unkar Rapid & $3-130$ & ---- & 72.6 & Chamel margin \\
\hline 72.7 & Left & Unnemed site & $3-132$ & $---\infty$ & 72.7 & Chamel margin \\
\hline 73.1 & Right & Lower Unkar Rapid & $3-133$ & ---- & 73.1 & Chamel margin \\
\hline 73.4 & Left & Unnamed site & $3-135$ & 73.4 & 73.3 & Chamel margin \\
\hline 73.7 & Left & Unnamed site & $3-137$ & 73.7 & ---- & Channel margin \\
\hline 73.7 & Right & Granary Camp & $3-137$ & ---- & 73.7 & Chamel margin \\
\hline 73.9 & Right & Unnamed site & $3-138$ & 73.9 & ---- & Chamel margin \\
\hline 74.0 & Right & Unnamed site & $3-138$ & 74.0 & --n & Separation \\
\hline 74.2 & Left & Unnamed site & $3-140$ & 74.2 & ---- & Chamel margin \\
\hline 74.3 & Left & Unnamed site & $3-142$ & 74.3 & 74.4 & Channel margin \\
\hline 74.3 & Right & Unnamed site & $3-142$ & 74.3 & ---- & Separation \\
\hline 74.7 & Left & Umamed site & $3-144$ & 74.7 & 74.7 & Chamel margin \\
\hline 74.7 & Right & Unnamed site & $3-144$ & ----- & 74.6 & Chamel margin \\
\hline 74.9 & Left & Escalante Creek & $3-145$ & 74.9 & 74.8 & Upper pool \\
\hline 75.0 & Right & Unnamed site & $3-145$ & ---- & 75.0 & Chamel margin \\
\hline 75.6 & Left & Nevills Rapid & $3-148$ & 75.5 & 75.5 & Separation \\
\hline 75.8 & Right & Opposite Papago Creek & $3-152$ & ---- & 75.8 & Reattachment \\
\hline 76.5 & Right & Unnamed site & $3-156$ & 76.4 & ----- & Chamel margin \\
\hline 76.6 & Left & Above Hance Rapid & $3-156$ & 76.5 & 76.4 & $\begin{array}{l}\text { Reattachment; } \\
\text { upper pool }\end{array}$ \\
\hline 77.2 & Left & Unnamed site & $3-161$ & 77.1 & ---- & Chamel margin \\
\hline 78.8 & Left & Sockdolager Rapid & $3-168$ & 78.8 & ----- & Upper pool \\
\hline 81.1 & Left & Above Grapevine Rapid & $3-181$ & 81.1 & 81.3 & $\begin{array}{l}\text { Chamel margin; } \\
\text { reattachment }\end{array}$ \\
\hline 82.6 & Right & $\begin{array}{l}\text { Eighty-Two and One- } \\
\text { Half Mile }\end{array}$ & 3-189 & 82.6 & ---- & Chamel margin \\
\hline 84.0 & Right & Clear Creek & $3-197$ & 84.0 & & $\begin{array}{l}\text { Separation; } \\
\text { reattachment }\end{array}$ \\
\hline 84.4 & Left & Above Zoroaster Rapid & $3-201$ & 84.4 & ---- & Separation \\
\hline 85.7 & Left & Cremation Creek & $3-207$ & 85.7 & ---- & Chamel margin \\
\hline 87.1 & Left & Cremation Camp & $3-215$ & 87.1 & 87.1 & Separation \\
\hline 87.2 & Right & Roys Beach Camp & $3-216$ & ---- & 87.1 & Channel margin \\
\hline 88.0 & Left & Unnamed site & $3-220$ & 88.0 & ---- & Channel margin \\
\hline
\end{tabular}


APPENDIX A

Comparison of river mile inventories of 1973 and 1983 from Lees Ferry to Stone Creek--Continued

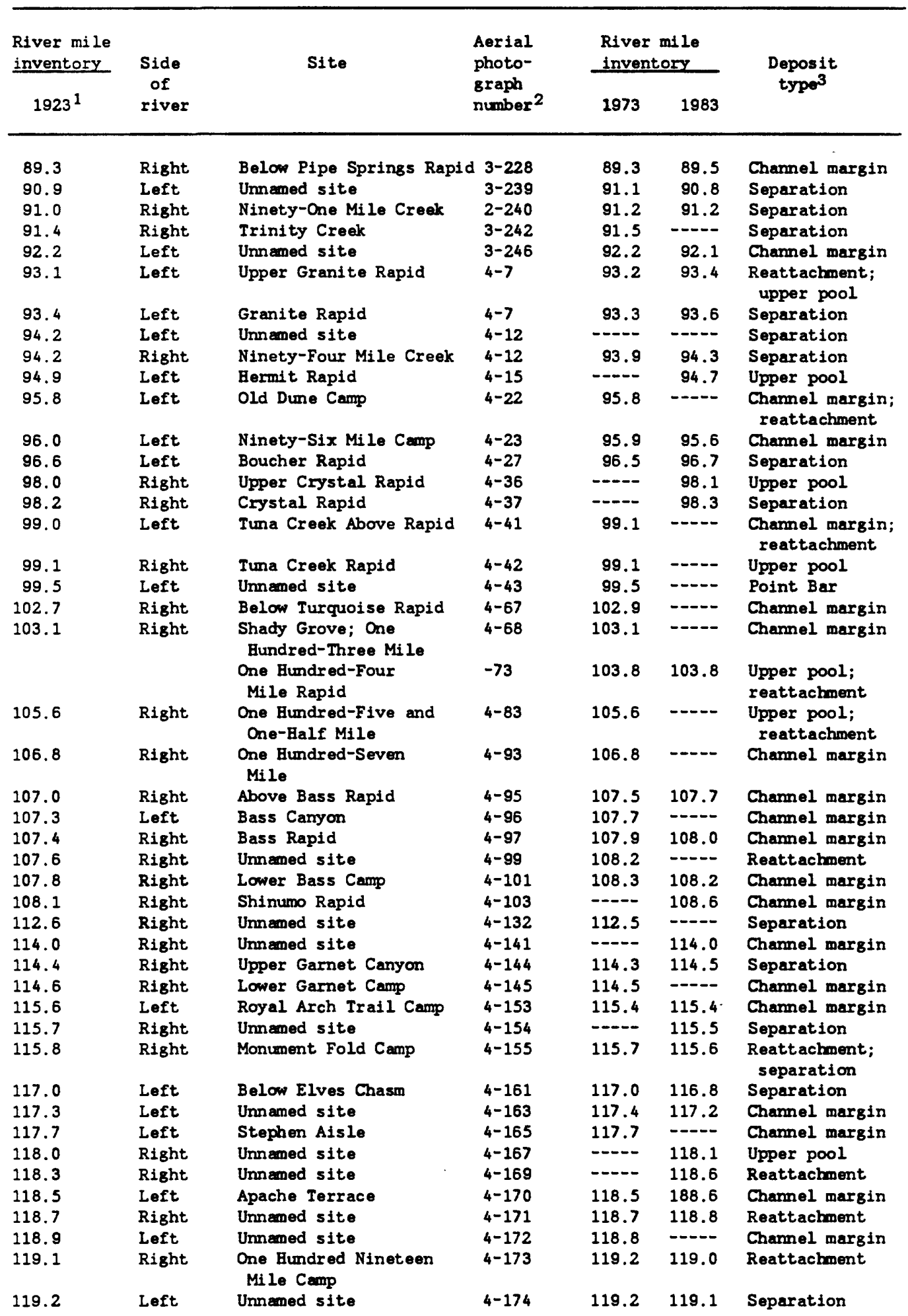

See footnotes at end of table. 
Camparison of river mile inventories of 1973 and 1983 from Lees Ferry to Stone Creek--Continued

\begin{tabular}{|c|c|c|c|c|c|c|}
\hline \multirow{2}{*}{$\begin{array}{l}\begin{array}{l}\text { River mile } \\
\text { inventory }\end{array} \\
1923^{1}\end{array}$} & \multirow{2}{*}{$\begin{array}{l}\text { Side } \\
\text { of } \\
\text { river }\end{array}$} & \multirow[t]{2}{*}{ Site } & \multirow{2}{*}{$\begin{array}{l}\text { Aerial } \\
\text { photo- } \\
\text { graph } \\
\text { number } 2\end{array}$} & \multicolumn{2}{|c|}{$\begin{array}{l}\text { River mile } \\
\text { inventory }\end{array}$} & \multirow{2}{*}{$\begin{array}{c}\text { Deposit } \\
\text { type } 3\end{array}$} \\
\hline & & & & 1973 & 1983 & \\
\hline 119.4 & Right & Unnamed site & 4-175 & ---- & 119.3 & Chamel margin \\
\hline 119.4 & Left & Umamed site & $4-175$ & $-\cdots$ & 119.4 & Reattachment \\
\hline 119.7 & Left & $\begin{array}{l}\text { One Hundred Twenty } \\
\text { Mile Camp }\end{array}$ & $4-176$ & 119.7 & 119.8 & $\begin{array}{l}\text { Channel margin; } \\
\text { reattachment }\end{array}$ \\
\hline 119.8 & Right & Unnamed site & $4-177$ & ---- & 119.8 & Reattachment \\
\hline 120.0 & Left & Unnamed site & $4-178$ & 119.9 & $-\cdots$ & Chamel margin \\
\hline 120.0 & Right & Upper Blacktail Rapid & 4-178 & 120.1 & 120.0 & Upper pool \\
\hline 120.1 & Right & Lower Blacktail Rapid & $4-178$ & ---- & 120.2 & Separation \\
\hline 120.2 & Left & Opposite Blacktail Rapid & $4-179$ & 120.5 & 120.5 & Chamnel margin \\
\hline 120.5 & Left & Below Blacktail Rapid & $4-181$ & 120.5 & 120.5 & Separation \\
\hline 121.5 & Left & Unnamed site & $4-186$ & 121.6 & $-\cdots$ & Upper pool \\
\hline 121.6 & Left & $\begin{array}{l}\text { One Hundred-Twenty- } \\
\text { Two Mile Rapid }\end{array}$ & $4-187$ & 121.7 & 121.8 & Separation \\
\hline 121.8 & Left & Unnamed site & $4-188$ & 121.9 & ---- & Channel margin \\
\hline 122.0 & Right & $\begin{array}{l}\text { One Hundred Twenty- } \\
\text { Two Mile Creek }\end{array}$ & $4-189$ & 122.0 & 122.2 & $\begin{array}{l}\text { Reattachment; } \\
\text { upper pool }\end{array}$ \\
\hline 122.2 & Left & Unnamed site & $4-190$ & 122.2 & $-\cdots$ & Chamel margin \\
\hline 122.3 & Left & The Cutbank & 4-191 & $-\cdots$ & 122.2 & Reattachment \\
\hline 122.6 & Left & Forster Rapid & $4-192$ & 122.7 & 122.6 & $\begin{array}{l}\text { Reattachment; } \\
\text { upper pool }\end{array}$ \\
\hline 122.7 & Left & Unnamed site & $4-193$ & 122.8 & $-\cdots$ & Channel margin \\
\hline 122.9 & Left & Unnamed site & $4-194$ & --- & 123.0 & Reattachment \\
\hline 123.2 & Left & $\begin{array}{l}\text { Upper Enfilade Point } \\
\text { Carmp }\end{array}$ & $4-197$ & --- & ---- & Channel margin \\
\hline 123.5 & Left & Enfilade Point & $4-198$ & 123.5 & 123.2 & Separation \\
\hline 123.8 & Right & Unnamed site & $4-200$ & --- & 124.0 & Chamel margin \\
\hline 124.2 & Left & Unnamed site & $4-202$ & $-\cdots$ & 124.6 & Channel margin \\
\hline 124.3 & Left & Unnamed site & 4-202 & 124.4 & 124.8 & Separation \\
\hline 124.6 & Left & Fossil Rapid & $4-205$ & ---- & 124.9 & Chamel margin \\
\hline 125.2 & Left & Below Fossil Rapid & $4-207$ & 125.2 & ---- & Channel margin \\
\hline 125.2 & Right & Unnamed site & $4-207$ & $-\cdots$ & 125.2 & Chamel margin \\
\hline 125.4 & Left & $\begin{array}{l}\text { One Bundred Twenty-Six } \\
\text { Mile Camp }\end{array}$ & $4-208$ & 125.4 & 125.8 & $\begin{array}{l}\text { Chamel margin; } \\
\text { reattachment }\end{array}$ \\
\hline 125.5 & Left & Unnamed site & $4-209$ & 125.5 & 125.8 & $\begin{array}{l}\text { Channel margin } \\
\text { reattachment }\end{array}$ \\
\hline 126.1 & Left & Unmamed site & $4-213$ & 126.2 & 126.0 & Separation \\
\hline 126.3 & Right & Randy's Rock & $4-215$ & 126.3 & 126.5 & Upper pool \\
\hline 127.7 & Left & Below bedrock & $4-224$ & 127.7 & $-\ldots$ & Separation \\
\hline 131.0 & Right & Above Dubby & $4-244$ & 131.0 & 131.0 & Separagion \\
\hline 131.1 & Right & Unnamed site & $4-246$ & $\cdots$ & 131.3 & Chamnel margin \\
\hline 131.4 & Right & Just above Dubby & $4-247$ & 131.6 & 131.8 & $\begin{array}{l}\text { Upper pool; } \\
\text { channel margin }\end{array}$ \\
\hline 131.8 & Right & Stone Creek & $4-249$ & 131.9 & 132.0 & $\begin{array}{l}\text { Separation; } \\
\text { reattachment }\end{array}$ \\
\hline 132.0 & Left & Unnamed site & $5-4$ & 132.1 & $-\cdots$ & Chamnel margin \\
\hline 133.0 & Left & $\begin{array}{l}\text { Opposite One Bundred } \\
\text { Thirty-Three Mile } \\
\text { Creek }\end{array}$ & $5-11$ & 133.1 & 133.0 & Separation \\
\hline 133.1 & Left & Racetrack & $5-11$ & --- & 133.1 & Reattachment \\
\hline 133.4 & Right & Upper Tapeats & $5-13$ & --- & 133.7 & Channel margin \\
\hline 133.7 & Right & Tapeats Creak Mouth & $5-14$ & --- & 133.8 & Chamnel margin \\
\hline 133.8 & Right & Unnamed site & $5-15$ & $-\cdots$ & 133.9 & Chamnel margin \\
\hline 133.8 & Right & Lower Tapeats Rapid & $5-15$ & 133.9 & 133.9 & Chamnel margin \\
\hline 134.1 & Left & Unnamed site & $5-17$ & 134.2 & 134.1 & Channel margin \\
\hline 134.5 & Left & Unnamed site & $5-20$ & 134.5 & 134.5 & $\begin{array}{l}\text { Separation; } \\
\text { reattachment }\end{array}$ \\
\hline
\end{tabular}


Comparison of river mile inventories of 1973 and 1983 from Lees Ferry to Stone Creek--Continued

\begin{tabular}{|c|c|c|c|c|c|c|}
\hline \multirow{2}{*}{$\begin{array}{l}\begin{array}{l}\text { River mile } \\
\text { inventory }\end{array} \\
19231\end{array}$} & \multirow{2}{*}{$\begin{array}{l}\text { Side } \\
\text { of } \\
\text { river }\end{array}$} & \multirow[t]{2}{*}{ Site } & \multirow{2}{*}{$\begin{array}{l}\text { Aerial } \\
\text { photo- } \\
\text { graph } \\
\text { number } 2\end{array}$} & \multicolumn{2}{|c|}{$\begin{array}{l}\text { River mile } \\
\text { inventory }\end{array}$} & \multirow{2}{*}{$\begin{array}{c}\text { Deposit } \\
\text { type }\end{array}$} \\
\hline & & & & 1973 & 1983 & \\
\hline 134.8 & Left & Owl Eyes Camp & $5-22$ & $---\infty$ & 134.8 & Chamel margin \\
\hline 134.7 & Right & $\begin{array}{l}\text { One Hundred Thirty- } \\
\text { Five Mile Rapid }\end{array}$ & $5-21$ & ---- & 134.8 & Chamel margin \\
\hline 134.8 & Right & $\begin{array}{l}\text { Above Granite Narrows } \\
\text { Camp }\end{array}$ & $5-21$ & ---- & 134.9 & Channel margin \\
\hline 136.1 & Left & Granite Narrows Camp & $5-29$ & 136.0 & --- & Channel margin \\
\hline 136.2 & Left & $\begin{array}{l}\text { Opposite Deer Creek } \\
\text { Falls }\end{array}$ & $5-31$ & 136.2 & 136.2 & Chamel margin \\
\hline 136.4 & Left & Lower Deer Creek Camp & $5-32$ & 136.4 & 136.5 & Separation \\
\hline 136.5 & Left & Unnamed site & $5-32$ & 136.5 & 136.6 & $\begin{array}{l}\text { Chamel margin; } \\
\text { reattachment }\end{array}$ \\
\hline 136.6 & Left & Unnamed site & $5-33$ & ---- & 136.7 & $\begin{array}{l}\text { Chamel margin; } \\
\text { reattachment }\end{array}$ \\
\hline 136.7 & Left & $\begin{array}{l}\text { Above Poncho's Kitchen } \\
\text { Camp }\end{array}$ & $5-34$ & ---- & 136.8 & Separation; \\
\hline 137.0 & Left & Poncho's Kitchen Camp & $5-36$ & 137.0 & ---- & Separation \\
\hline 137.0 & Left & Lower Poncho's Camp & $5-36$ & 137.1 & --- & Reattachment; \\
\hline 137.1 & Left & Below Poncho's Camp & $5-37$ & ---- & $-\infty-\infty$ & Separation \\
\hline 137.4 & Left & Unnamed site & $5-39$ & ---- & 137.3 & Chamel margin \\
\hline 137.3 & Right & Unnamed site & $5-39$ & $---\infty$ & ---- & $\begin{array}{l}\text { Separation; } \\
\text { reattachment }\end{array}$ \\
\hline 137.5 & Right & Unnamed site & $5-39$ & $---\infty$ & 137.3 & Chamel margin \\
\hline 137.6 & Left & $\begin{array}{l}\text { One Hundred Thirty- } \\
\text { Seven and One-Half } \\
\text { Mile Rapid }\end{array}$ & $5-40$ & 137.7 & 137.5 & Channel margin \\
\hline 137.9 & Left & Unnemed site & $5-42$ & 137.9 & 137.8 & Separation \\
\hline 138.2 & Left & Unnamed site & $5-44$ & 138.3 & 138.0 & Separation \\
\hline 138.4 & Left & Unnemed site & $5-45$ & 138.5 & --- & Chamel margin \\
\hline 138.6 & Right & Unnamed site & $5-46$ & ---- & 138.7 & Reattachment \\
\hline 138.9 & Right & Fishtail Rapid & $5-48$ & 138.9 & 139.0 & Upper pool \\
\hline 139.3 & Left & Unnamed site & $5-51$ & 139.4 & 139.5 & Chamel margin \\
\hline 139.3 & Right & Unnamed site & $5-51$ & 139.4 & ---- & Chamel margin \\
\hline 139.7 & Left & $\begin{array}{l}\text { One Eundred Forty } \\
\text { Mile Canyon }\end{array}$ & $5-53$ & 139.7 & 139.8 & $\begin{array}{l}\text { Reattachment; } \\
\text { upper pool }\end{array}$ \\
\hline 139.9 & Left & Unnamed site & $5-54$ & 139.9 & --- & Separation \\
\hline 140.2 & Left & Unnamed site & $5-56$ & ---- & 140.3 & Chamel margin \\
\hline 141.0 & Left & Unnamed site & $5-60$ & ---- & 141.0 & $\begin{array}{l}\text { Separation; } \\
\text { Reattachment }\end{array}$ \\
\hline 141.4 & Left & Unnamed site & $5-62$ & $---\infty$ & 141.4 & Chamel margin \\
\hline 142.4 & Right & Unnamed site & $5-69$ & ---- & 142.5 & Chamel margin \\
\hline 143.4 & Left & Above Kanab Rapid & $5-74$ & 143.3 & 143.4 & Chamel margin \\
\hline 143.1 & Right & Unnamed site & $5-74$ & ---- & 143.0 & Chamel margin \\
\hline 143.5 & Right & Mouth of Kanab Creek & $5-75$ & ---- & 143.5 & Chamel margin \\
\hline 145.0 & Left & Unnamed site & $5-84$ & --- & 145.1 & Channel margin \\
\hline 145.6 & Left & Olo Canyon & $5-88$ & 145.4 & 145.5 & Separation \\
\hline 147.7 & Right & $\begin{array}{l}\text { Spring Above } \\
\text { Matkatamiba Rapid }\end{array}$ & $5-102$ & ---- & 147.7 & Chamel margin \\
\hline 147.9 & Right & Matkatamiba Rapid & $5-103$ & $---\infty$ & 147.8 & Chamel margin \\
\hline 148.5 & Left & Lower Matkatamiba Rapid & $5-106$ & 148.3 & 148.4 & Channel margin \\
\hline 149.7 & Right & Upset Rapids & $5-114$ & 149.8 & 149.7 & Separation \\
\hline 151.6 & Right & Ledges Camp & $5-122$ & 151.6 & 151.8 & Rock \\
\hline 152.3 & Left & Unnamed site & $5-128$ & 152.3 & --- & Separation \\
\hline 153.6 & Right & Sinyala Rapid & $5-133$ & ---- & 153.5 & Separation \\
\hline 153.8 & Left & Sinyala Ledges Camp & $5-135$ & 153.8 & $-\infty-\infty$ & Rock \\
\hline 154.9 & Right & Rockfall Lower Ledges & $5-140$ & ---- & 155.0 & $\begin{array}{l}\text { Chamel margin } \\
\text { reattachment }\end{array}$ \\
\hline 155.7 & Right & Last Chance Camp & $5-146$ & 155.6 & 155.7 & Upper pool \\
\hline
\end{tabular}




\begin{tabular}{|c|c|c|c|c|c|c|}
\hline \multirow{2}{*}{$\begin{array}{c}\begin{array}{c}\text { River mile } \\
\text { inventory }\end{array} \\
{ }_{1923^{1}}\end{array}$} & \multirow{2}{*}{$\begin{array}{l}\text { Side } \\
\text { of } \\
\text { river }\end{array}$} & \multirow[t]{2}{*}{ Site } & \multirow{2}{*}{$\begin{array}{l}\text { Aerial } \\
\text { photo- } \\
\text { graph } \\
\text { number } 2\end{array}$} & \multicolumn{2}{|c|}{$\begin{array}{l}\text { River mile } \\
\text { inventory }\end{array}$} & \multirow{2}{*}{$\begin{array}{l}\text { Depos 1t } \\
\text { type } 3\end{array}$} \\
\hline & & & & 1973 & 1983 & \\
\hline 155.8 & R1ght & Unnamed site & $5-146$ & $-\cdots$ & -... & Separation \\
\hline 156.3 & Right & Unnamed site & $5-150$ & ---- & 156.2 & Channel margin \\
\hline 156.6 & Left & Unnamed site & $5-151$ & ---- & 156.5 & Chamel margin \\
\hline 157.8 & Right & Unnamed site & $5-158$ & $-\cdots$ & 157.7 & Chamel margin \\
\hline 158.0 & Left & Unnamed site & $5-159$ & 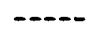 & 157.8 & Channel margin \\
\hline 158.3 & Right & Unnamed site & $5-159$ & 158.1 & -..- & Channel margin \\
\hline 158.7 & Right & Unnamed site & $5-161$ & 158.6 & 158.5 & Chamel margin \\
\hline 159.4 & RIght & Unnamed site & $5-167$ & $\cdots$ & 159.3 & Separation \\
\hline 159.9 & Left & Unnamed site & $5-170$ & 159.8 & -.... & Channel margin \\
\hline 160.4 & Left & Unnamed site & $5-172$ & ---- & 160.4 & Channel margin \\
\hline 160.7 & Right & Unnamed site & $5-175$ & 160.7 & $-\cdots$ & Separation \\
\hline 161.6 & Right & Unnamed site & $5-180$ & ---- & 161.6 & Chamnel margin \\
\hline 162.0 & Left & Unnamed site & $5-182$ & $\cdots-$ & 162.0 & Separation \\
\hline 162.1 & Left & Unnamed site & $5-182$ & $\cdots$ & $\ldots$ & Chamel margin \\
\hline 162.4 & Left & Unnamed site & $5-184$ & $\ldots$ & 162.5 & Channel margin \\
\hline 162.8 & & Unnamed site & $5-187$ & $\cdots$ & 163.0 & $\begin{array}{l}\text { Upper pool; } \\
\text { Reattachment }\end{array}$ \\
\hline 163.1 & Right & Unnamed site & $5-189$ & - & 163.2 & $\begin{array}{l}\text { Separation; } \\
\text { Reattachment }\end{array}$ \\
\hline 163.3 & Left & Unnamed site & $5-190$ & $\cdots$ & 163.5 & Channel margin \\
\hline 163.9 & Left & Unnamed site & $5-193$ & 163.9 & 163.9 & Channel margin \\
\hline 164.5 & Right & $\begin{array}{l}\text { One Hundred Sixty-Four } \\
\text { Mile Rapid }\end{array}$ & 5-199 & 164.5 & 164.5 & Separation \\
\hline 164.9 & Right & Unnamed site & $5-202$ & --.- & 165.0 & Chamel margin \\
\hline 165.0 & Left & Unnamed site & $5-202$ & $\cdots$ & 165.0 & Reattachment \\
\hline 165.1 & Right & Unnamed site & $5-203$ & $\cdots$ & 165.2 & Reattachment \\
\hline 165.7 & Left & Unnamed site & $5-206$ & $\cdots$ & 165.7 & Reattachment \\
\hline $\begin{array}{l}165.8 \\
165.9\end{array}$ & $\begin{array}{l}\text { Left } \\
\text { Left }\end{array}$ & $\begin{array}{l}\text { Unnamed site } \\
\text { Unnamed site }\end{array}$ & $\begin{array}{l}5-207 \\
5-207\end{array}$ & $\cdots$ & $\begin{array}{l}165.8 \\
166.0\end{array}$ & $\begin{array}{l}\text { Chamel margin } \\
\text { Separation }\end{array}$ \\
\hline 165.9 & Left & Unnamed site & $5-208$ & $\cdots$ & $\cdots$ & Chamel margin \\
\hline 166.3 & Left & $\begin{array}{l}\text { Above Upper National } \\
\text { Rapid }\end{array}$ & $5-210$ &..-- & -...- & Channel margin \\
\hline 166.4 & Left & Upper National Rapid & $5-211$ & 166.5 & 166.5 & $\begin{array}{l}\text { Channel margin } \\
\text { Reattachment }\end{array}$ \\
\hline 166.5 & Left & National Rapid & $5-211$ & 166.6 & 166.6 & Separation \\
\hline
\end{tabular}

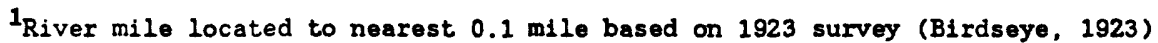
as plotted on 1984 airphotos.

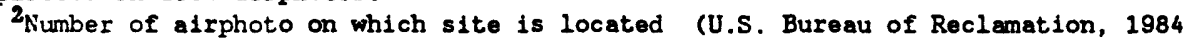
series).

${ }^{3}$ Largest deposit type listed first. 